UNIVERSIDADE DE SÃO PAULO

FACULDADE DE FILOSOFIA, LETRAS E CIÊNCIAS HUMANAS DEPARTAMENTO DE HISTÓRIA

PROGRAMA DE PÓS-GRADUAÇÃO EM HISTÓRIA SOCIAL

RODOLPHO GAUTHIER CARDOSO DOS SANTOS

\title{
A CONSTRUÇÃO DA AMEAÇA JUSTICIALISTA. ANTIPERONISMO, POLÍTICA E IMPRENSA NO BRASIL (1945-1955)
}

(VERSÃO CORRIGIDA) 
UNIVERSIDADE DE SÃO PAULO

FACULDADE DE FILOSOFIA, LETRAS E CIÊNCIAS HUMANAS

DEPARTAMENTO DE HISTÓRIA

PROGRAMA DE PÓS-GRADUAÇÃO EM HISTÓRIA SOCIAL

\section{A CONSTRUÇÃO DA AMEAÇA JUSTICIALISTA. ANTIPERONISMO, POLÍTICA E IMPRENSA NO BRASIL \\ (1945-1955) \\ (VERSÃO CORRIGIDA)}

Rodolpho Gauthier Cardoso dos Santos

Tese apresentada ao Programa de PósGraduação em História Social do Departamento de História da Faculdade de Filosofia, Letras e Ciências Humanas da Universidade de São Paulo, para a obtenção do título de Doutor em História.

Orientadora: Prof. ${ }^{a}$ Dr. $^{\text {a }}$ Maria Helena Rolim Capelato.

De acordo:

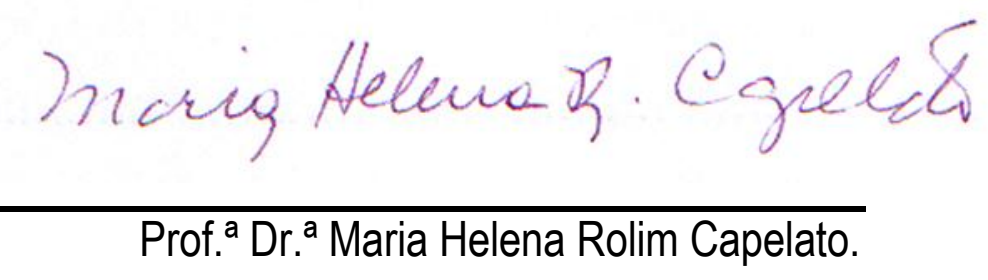

São Paulo

2015 
SANTOS, Rodolpho Gauthier Cardoso dos Santos. A construção da ameaça justicialista. Antiperonismo, política e imprensa no Brasil (1945-1955). Tese apresentada à Faculdade de Filosofia, Letras e Ciências Humanas da Universidade de São Paulo (USP), para obtenção do título de Doutor em História Social, 2015.

Aprovado em 29/06/2015.

Banca Examinadora:

Profa. Dra. Maria Helena Rolim Capelato (orientadora). Instituição: FFLCH-USP Julgamento: Assinatura:

Profa. Dra. Maria Ligia Coelho Prado

Instituição: FFLCH-USP

Julgamento: Assinatura:

Profa. Dra. Mary Anne Junqueira

Instituição: FFLCH-USP Julgamento: Assinatura:

Prof. Dr. Jorge Luiz Ferreira

Instituição: UFF

Julgamento: Assinatura: Assinatura: 


\section{Agradecimentos}

Agradeço minha orientadora, professora Maria Helena, pelo grande apoio, confiança e amizade cultivada ao longo desses últimos cinco anos de trabalho conjunto.

À professora Maria Ligia Coelho Prado, pelas aulas magistrais e pela acolhida sempre calorosa.

Ao professor José Alves de Freitas Neto, pelas boas indicações bibliográficas e pela agradável amizade de longa data.

Aos professores Jorge Luiz Ferreira e Mary Anne Junqueira por terem aceitado participar da defesa.

Ao professor e amigo Paulo Renato da Silva, que me deu bons conselhos e ótimas vibrações desde o momento em que este trabalho era apenas uma ideia mal formulada.

Ao professor argentino Ernesto Bohoslavsky pelo diálogo muito frutífero e pelas indicações bibliográficas valiosíssimas.

À professora Mônica Hirst, pelo acesso aos artigos escritos de sua autoria.

À professora Eliane Moura Silva, que me incentivou a persistir na carreira acadêmica num momento em que tantos outros caminhos pareciam possíveis.

À professora argentina Marcela García Sebastiani, da Universidad Complutense de Madrid, pela confiança e por aceitar me receber durante um período sanduíche que, por força de compromissos profissionais, acabou não se realizando.

A todos os meus colegas de pós-graduação que partilharam comigo gargalhadas e algumas angústias. Obrigado principalmente ao Alex, Annelise, Flávia Preto, Eliel, Ricardo, Ulisses, Êça, Lívia, Marcela e Ângela pelo companheirismo.

Aos pesquisadores membros do LEHA-USP (Laboratório de Estudos de História das Américas) pelas sugestões e comentários a respeito da pesquisa.

À Maria Clara Ruiz e Leopoldina Calligaris, amigas santafesinas de longa data com quem aprendi coisas sobre o peronismo que nem sempre estão nos livros.

À Priscila Pereira, historiadora de mão cheia, com quem pude trocar ideias e compartilhar o amor por esse país vizinho tão intrigante.

Ao Marcos Tolentino, que foi muito generoso em me enviar de Buenos Aires bibliografia bastante importante. 
Ao meu velho amigo poeta Cássio e à minha amiga Patrícia por sua amizade e paciência ao longo das minhas muitas viagens à capital paulista.

Aos amigos Natali Fabiana, "Gugu Poler", Juliana Attie, Eduardo, Tiago, Danilo, Fará e Luís Fernando. Cada um à sua maneira, eles me ajudaram a chegar até aqui. Trata-se de uma dívida emocional que terei prazer em pagar ao longo dos próximos anos.

Ao IFMG pela licença concedida, que se mostrou fundamental para terminar a tese. Sem dúvida, esse direito só pôde ser usufruído graças à longa luta travada pelos meus colegas de instituição.

A todos os funcionários dos arquivos e bibliotecas consultadas, especialmente a Carla Ramos, coordenadora de publicações seriadas da Biblioteca Nacional, e Gabriella da Silva Motta Barros, do arquivo Carlos Lacerda sediado na Universidade de Brasília (UnB).

À CAPES pela bolsa de doutorado, ainda que por apenas três meses.

À minha amada Ju e à sua família, que têm me feito cada vez mais mineiro e me proporcionado muitos momentos felizes.

Novamente, os agradecimentos maiores são dedicados aos de casa, principalmente minha mãe, meu pai e meu irmão. Mesmo sem entender profundamente o que eu estava fazendo, eles não deixaram de me apoiar e foram compreensivos com os muitos momentos em que tive de me privar de sua companhia.

A dedicatória precisa ser estendida, já que agora a família possui uma nova integrante. Que ela possa um viver num mundo menos desigual e que tenha oportunidade de usufruir de uma universidade pública, gratuita e de qualidade que eu, sua mãe e o seu pai conhecemos. Um beijo, Larinha! 


\section{RESUMO}

SANTOS, Rodolpho Gauthier Cardoso dos Santos. A construção da ameaça justicialista. Antiperonismo, política e imprensa no Brasil (1945-1955). Tese de Doutorado. Faculdade de Filosofia, Letras e Ciências Humanas da Universidade de São Paulo, São Paulo, 2015.

Esta tese analisa as representações produzidas pela imprensa liberal-conservadora brasileira a respeito do governo de Juan Domingo Perón na Argentina, especialmente no período de 1945 a 1955. Tais imagens, quase sempre negativas, faziam parte do imaginário político nacional e foram constantemente manipuladas para atuar no jogo político brasileiro. As principais fontes históricas desta pesquisa são a revista semanal ilustrada $O$ Cruzeiro, pertencente ao empresário da comunicação Assis Chateaubriand, e o diário carioca Tribuna da Imprensa, de propriedade do jornalista e político Carlos Lacerda, que integrava a União Democrática Nacional (UDN). Com base em notícias, editoriais, reportagens e charges veiculadas nesses periódicos, nota-se que, ao longo dos anos, o justicialismo foi associado, entre outras imagens, ao nazismo, à barbárie e a uma conspiração continental. Demonstra-se que o regime argentino foi apresentado não apenas como antimodelo político, mas como ameaça real à democracia brasileira, o que pode ter contribuído para a não aproximação entre as duas nações naquela época.

Palavras-chave: antiperonismo, imprensa, conservador, antivarguismo, história política. 


\begin{abstract}
SANTOS, Rodolpho Gauthier Cardoso dos Santos. The construction of the justicialist menace. Antiperonism, politics and press in Brasil (1945-1955). Doctorade in Social History. Faculdade de Filosofia, Letras e Ciências Humanas da Universidade de São Paulo, São Paulo, 2015.

This thesis analyzes the representations produced by the liberal-conservative Brazilian press about the Juan Domingo Perón government in Argentina, especially in the period of 1945 to 1955 . These images, often negative, were part of the national political imaginary and were constantly manipulated to be used in the Brazilian politics. This research has two main historical sources: the weekly magazine $O$ Cruzeiro, belonging to the businessman Assis Chateaubriand and the daily newspaper Tribuna da Imprensa. This one belonged to the journalist and politician Carlos Lacerda, who was a member of the party União Democrática Nacional (UDN). Based on news, editorials, articles and cartoons, it was noticed that over the years the Justicialism was associated, among other images, to nazism, to barbarism and to a continental conspiracy. It was demonstrated that the Argentinian regimen was presented not only as a non recommended model, but as a real threat to the Brazilian democracy, and this may have contributed to the no rapprochement between the two nations at that time.
\end{abstract}

Keywords: antiperonism, press, conservative, antivarguism, political history. 


\section{SUMÁRIO}

INTRODUÇÃO 9

Capítulo 1 - Perón, o nazista (1945-1950) ........................ 28

1.1 A CAMPANHA ANTIPERONISTA DE $O$ CRUZEIRO ................... 29

1.2 PERONISMO, o NAZISMO SUL-AMERICANO .......................... 35

1.3 UM NOVO ROSAS - A POLÍTICA EXTERNA PERONISTA .......... 47

CAPÍtulo 2 - A barbáRIE PERONista (1950-1953) .............. 61

2.1 CARlos LaCERDA E A TRIBUNA DA IMPRENSA ...................... 62

2.2 A CAMPANHA PRESIDENCIAL DE 1950................................. 73

2.3 PERÓN E A LIBERDADE DE IMPRENSA..................................... 82

2.4 AS PERSEGUIÇÕES AOS OPOSITORES................................... 94

2.5 A BOMBA ATÔMICA PERONISTA.......................................... 99

2.6 O POVO ESCLARECIDO CONTRA A MASSA FANÁTICA ......... 105

CAPÍTUlo 3 - OS CONSPIRAdORES (1953-1955) ................... 114

3.1 NovAS ACUSAÇÕES DE IMPERIALISMO.............................. 115

3.2 DENÚNCIAS DE INFILTRAÇÃO SINDICAL E JORNALÍSTICA .. 122

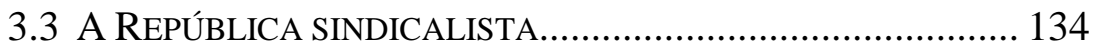

3.4 “PERÓN CUMPLE, PERO VARGAS NO DIGNIFICA"................ 148

3.5 O DEPOIMENTO DE JOÃO NEVES E O IMPEACHMENT ......... 168

3.6 A CARTA BRANDI ............................................................ 176

3.7 O RESUltado DAS ELEIÇÕES E DAS INVESTIGAÇÕES ......... 191

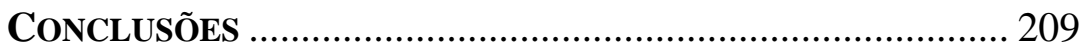

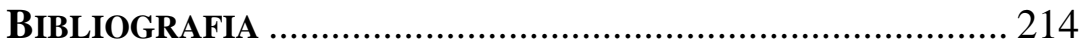

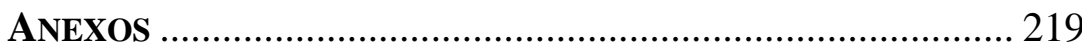




\section{INTRODUÇÃO}

Três de outubro de 1955. Enquanto milhões de brasileiros se dirigiam às urnas para votar em seus candidatos a presidente e a vice-presidente da República, a Rádio Globo, no Rio de Janeiro, interrompeu sua programação. O objetivo era divulgar o conteúdo de uma nota emitida pelo então ministro da Guerra, general Henrique Teixeira Lott. $\mathrm{O}$ assunto eram as investigações oficiais envolvendo a polêmica carta Brandi. De acordo com esse documento, um dos candidatos à vice-presidente, João Goulart (Partido Trabalhista Brasileiro, PTB), estava envolvido na compra de armas da Argentina peronista e na formação de "brigadas de choque operárias". Brandi, deputado peronista da província de Corrientes, era o suposto remetente da missiva ao político gaúcho.

$\mathrm{Na}$ nota divulgada à imprensa, Lott informou que as investigações haviam obtido um laudo pericial da Polícia Federal argentina. Essa análise técnica assegurava ser "sumamente provável" a autenticidade da assinatura presente na carta. Contrariando a legislação eleitoral, que proibia propaganda política 48 horas antes do pleito, o jornalista e deputado federal Carlos Lacerda (União Democrática Nacional, UDN) discursou na mesma emissora. Ele comemorou efusivamente o resultado:

[...] eis que a misericórdia de Deus põe em nossas mãos, na hora oportuna -
ainda que parecendo tardia - um documento cuja comprovação agora coloca
os brasileiros diante de um dever iniludível: o dever de repelir a traição e
puni-la dentro da lei, para que a Nação respire, desafogada e tranquila.
É por nossos filhos, é por nossa gente, é por nossa terra, que eu venho à
Rádio Globo, congratular-me com a Nação brasileira, com o povo brasileiro e
agradecer a Deus, numa prece fervente, pela misericórdia que nos fez, pela
graça que nos deu, proporcionando ao Brasil esta oportunidade - talvez única
e talvez mesmo derradeira - de comprovar a traição contra ele longamente
premeditada e demoradamente consumada e que agora, ainda a tempo, se
pode contrarrestar e inutilizar, através da consciência, através dos atos
conscientes, através das ações lúcidas patrióticas e inspiradas na misericórdia
de Deus para com os filhos desta grande Pátria. ${ }^{1}$

Mesmo com a divulgação do laudo no dia da eleição e com essa retórica verborrágica de Lacerda, Goulart venceu o pleito por uma estreita margem de pouco mais de duzentos mil votos. Soube-se dias depois, com base em outras análises grafológicas, que o documento era uma falsificação grosseira. A crise política pelo qual passava o país avolumou-se e, em 11 de novembro, o mesmo general Lott mobilizou

\footnotetext{
1 “A polícia argentina comprova: a Carta de Brandi é autêntica” In Tribuna da Imprensa, Rio de Janeiro, 4/10/1955, p. 1 (primeiro caderno) e 8 (segundo caderno).
} 
tropas para garantir a posse dos eleitos. Lacerda, cuja participação na falsificação da carta Brandi até hoje permanece nebulosa, refugiou-se temporariamente no cruzador Tamandaré, junto com outros políticos e militares que clamavam pela intervenção armada. $^{2}$

O episódio da carta Brandi, que poderia ter alterado os rumos políticos do País, demonstra o poderoso imaginário antiperonista construído por grupos contrários ao trabalhismo e a seus seguidores, principalmente nas décadas de 1950 e 1960. Nesses anos, muito papel foi gasto no Brasil para veicular ideias e imagens negativas a respeito da experiência política justicialista. Como se verá, o regime argentino não foi apresentado apenas como antimodelo político, mas como ameaça real à democracia brasileira mediante a aliança com políticos trabalhistas locais. A iminente possibilidade de que isso se confirmasse explica em parte o regozijo de Lacerda observado em seu discurso radifônico.

Este trabalho se debruça sobre as representações a respeito da primeira experiência justicialista na Argentina difundidas principalmente por alguns órgãos de imprensa adversários do trabalhismo. Compreender o significado político delas é o objetivo central da pesquisa. Interessa aqui entender como as imagens a respeito do governo argentino foram produzidas e instrumentalizadas para atuar como arma no jogo político brasileiro.

Não se pretende realizar um estudo do peronismo em si, mas a respeito dos usos da figura de Perón e de sua política pelos meios de comunicação liberais-conservadores brasileiros. Importa mostrar que temas como liberdade de expressão, democracia, nacionalismo econômico, direitos trabalhistas, imperialismo, alinhamento (ou não) aos Estados Unidos e outros foram debatidos levando-se em conta o que ocorria no país vizinho. Partiu-se do pressuposto de que o peronismo, como modelo político a ser seguido ou rejeitado, contribuiu para as definições da vida política brasileira do período.

Ao longo do trabalho, a imprensa escrita liberal-conservadora é o principal tipo de fonte, especialmente a revista semanal ilustrada $O$ Cruzeiro e o diário vespertino carioca Tribuna da Imprensa. Em uma época em que as transmissões de televisão ainda eram muito incipientes, os meios de comunicação escritos funcionavam frequentemente como plataforma para líderes e partidos. Ainda que advogassem um ideal de

\footnotetext{
${ }^{2}$ MENDONÇA, Marina Gusmão de. O demolidor de presidentes. São Paulo: Códex, 2002, 2a . Edição, p. 187.
} 
neutralidade, a força de sua atuação é inegável e torna-se visível em momentos de crises políticas como os que ocorreram no período estudado.

Existiram também, vale lembrar, alguns meios de comunicação brasileiros favoráveis ao regime argentino, que enfatizaram positivamente a semelhança de sua política social com o varguismo. No entanto, o alcance dessas manifestações foi consideravelmente menor. De modo geral, a grande imprensa adotou postura contrária ao que acontecia na Argentina, onde muitos meios de comunicação foram fechados e censurados pelo regime peronista.

A tese se debruça sobre um período da história do Brasil que já foi definido inúmeras vezes como "República populista" (1945-1964). O termo tem conotação pejorativa porque vem associado a demagogia, manipulação e corrupção. No entanto, autores que expressam essa interpretação geralmente não levam em conta importantes avanços em termos democráticos, como a ampliação do direito de voto e o surgimento de partidos nacionais dotados de ideologias relativamente claras. Além disso, eleições fiscalizadas pela Justiça Eleitoral passaram a ser realizadas periodicamente.

A perspectiva aqui defendida tende a coincidir com a da historiadora Ângela de Castro Gomes, que se vale da expressão "Terceira República" para se referir ao período. ${ }^{3}$ Não se pode, como ela afirma, ignorar os notáveis avanços em relação ao exercício da cidadania ocorridos em um das épocas em que mais se praticou democracia no Brasil. Criticar aquele sistema político apontando apenas suas limitações pode indicar implicitamente a noção equivocada da existência de uma única e "verdadeira democracia”.

A respeito dessa discussão conceitual, vale lembrar também que, em inúmeros trabalhos acadêmicos, varguismo e peronismo foram apontados como exemplos expressivos do "populismo latino-americano". ${ }^{4}$ Propositalmente, deixa-se de lado aqui a vastíssima bibliografia a respeito dessa expressão e evita-se usá-la porque, como defende Maria Helena Rolim Capelato, as especificidades de cada regime político tendem a ser obliteradas nessas interpretações generalizantes. ${ }^{5}$

\footnotetext{
${ }^{3}$ Ver: GOMES, Angela de Angela de Castro. "Jango e a República de 1945-1964: da República Populista à Terceira República", in: Rachel Soihet; Maria Regina Celestino Almeida; Cecília Azevedo; Rebeca Gontijo (orgs.). Mitos, projetos e práticas políticas. Memória e historiografia. Rio de Janeiro, Civilização Brasileira, 2009.

${ }^{4}$ Para a problematização da expressão "populismo latino-americano", ver: CAPELATO, Maria Helena Rolim. Populismo latino-americano em discussão. In: FERREIRA, Jorge (org). O populismo e sua história: debate e crítica. Rio de Janeiro: Civilização Brasileira, 2001, p. 127-165.

5 CAPELATO, Maria Helena Rolim. Multidões em Cena: Propaganda Política no Varguismo e no Peronismo. 2a edição. São Paulo: Editora UNESP, 2008, p. 23-26.
} 
Embora os meios de comunicação liberal-conservadores tenham insistido nas semelhanças entre varguismo e peronismo, os dois líderes, como se verá, adotaram posturas muito particulares em relação à política externa, às relações com a imprensa e a outros aspectos importantes. Parte das dificuldades de entendimento entre Brasil e Argentina no período esteve relacionada justamente às diferentes conjunturas nacionais.

O trabalho inicia-se em 1945, ano de grandes transformações políticas no Brasil e também na Argentina. Enquanto Perón ganhou destaque na cena política platina e tornou-se presidente no ano seguinte, o governo ditatorial de Vargas foi deposto e estabeleceu-se uma ordem democrática. Acompanha-se a repercussão da política justicialista até o final de 1955, quando ocorreu o episódio da carta Brandi e se encerrou a primeira experiência peronista por meio de um golpe de estado. ${ }^{6}$

A pesquisa insere-se no campo da nova história política, corrente historiográfica que introduziu perspectivas de abordagem fecundas ao sugerir temas e fontes originais, entre elas a imprensa. ${ }^{7}$ Historiadores como René Rémond enfatizam que a nova história política deve preocupar-se com outros atores sociais e não apenas com aqueles que ocupam a cúpula do Estado. ${ }^{8}$ Tanto quanto os discursos e monumentos oficiais, as representações construídas em vários âmbitos podem ser elementos mobilizadores extremamente poderosos e devem ser analisados historicamente. ${ }^{9}$

O trabalho vale-se de dois conceitos-chave: representação e imaginário social. O conceito de representação, oriundo da história cultural, foi incorporado à nova história política e pode ser pensado, grosso modo, como toda "tradução mental de uma realidade exterior percebida" e ligada ao processo de abstração. ${ }^{10}$ Para o historiador francês Roger Chartier, "as estruturas do mundo social não são um dado objetivo [...] mas produzidas pelas práticas articuladas (políticas, sociais, discursivas) que constroem as suas

\footnotetext{
${ }^{6}$ A queda do regime justicialista não eliminou a ação dos detratores do líder platino no Brasil. Na fase presidencialista do governo João Goulart (1963-1964), este foi retratado com frequência pelos jornais liberais-conservadores como admirador de Perón. Outras pesquisas poderão demonstrar a especificidade e o alcance das representações relacionadas ao peronismo às vésperas do golpe militar brasileiro. Nesta investigação, não foi possível alcançá-las. Ver: MOTTA, Rodrigo Patto Sá. Jango e o golpe de 1964 na caricatura. Rio de Janeiro, Jorge Zahar Ed., 2006, p. 148.

${ }^{7}$ A respeito dessa renovação, verificar: JULLIARD, Jacques. A política. In: LE GOFF, Jacques e NORA, Pierre (org.) História: novas abordagens. Rio de Janeiro: Francisco Alves, 1976.

${ }^{8}$ RÉMOND, Rene. Uma história presente. In: RÉMOND, Rene. (org.). Por uma história política. Rio de Janeiro: FGV, 1996.p. 13-36.

${ }^{9}$ No Brasil, a história política ganhou grande alento a partir dos anos 1980. Como notou Maria Helena Rolim Capelato, parte dessa renovação de interesse relaciona-se ao próprio processo de redemocratização do País e à necessidade de compreensão de um novo sistema político. CAPELATO, Maria H. R. "História Política" IN Revista Estudos Históricos, Vol. 9, № 17, Rio de Janeiro: CPDOC/FGV, 1996.

${ }^{10}$ LE GOFF, Jacques apud PESAVENTO, Sandra Jatahy. Em Busca de Uma Outra História: Imaginando o imaginário. Revista Brasileira de História, São Paulo, v. 15, n. 29, p. 15, 1995.
} 
figuras". ${ }^{11}$ Partindo desse pressuposto, ele defende que parte da importância das representações está no fato de que elas dão sentido ao mundo ao permitirem o trabalho de "classificação e de recorte que produz configurações intelectuais múltiplas pelas quais a realidade é contraditoriamente construída pelos diferentes grupos que compõem uma sociedade". ${ }^{12}$ Assim, ao mesmo tempo em que tornam inteligível o real, as representações ajudam a produzi-lo de acordo com os interesses sociais mais diversos.

Com frequência, o processo de construção de representações resulta em um conjunto simbólico amplo e compartilhado, que é capaz de mobilizar e influenciar mais profundamente as práticas políticas. Aproxima-se então, do conceito de imaginário social, que está vinculado a símbolos, imagens e projeções imaginadas da realidade produzidas coletivamente ao longo do tempo. Como se sabe, o imaginário social não deve ser tomado como sinônimo de algo irreal ou ilusório, pois, ao nortear a leitura do mundo de determinada sociedade, configura-se como parte dessa realidade.

Para o historiador polonês Bronislaw Baczko, os imaginários sociais são especialmente importantes nos conflitos políticos, pois nesses embates não se pode separar "os agentes e seus atos das imagens que têm de si próprios e de seus inimigos". ${ }^{13}$ Ou seja, as autoimagens são fundamentais para compreender tais disputas. O autor faz outras assertivas importantes ao enfatizar que:

O dispositivo imaginário assegura a um grupo social quer um esquema coletivo de interpretação das experiências individuais, tão complexas quanto variadas, quer uma codificação das expectativas e das esperanças. Um só e mesmo código permite fazer concordar as expectativas individuais, exprimir as coincidências e as contradições entre as experiências e as esperanças, e ainda sustentar os indivíduos em ações comuns. Com efeito, o imaginário social informa acerca da realidade ao mesmo tempo que constitui um apelo à ação $[\ldots] .^{14}$

Como evidenciado no trecho, a compreensão dos imaginários sociais é uma chave importante para desbravar os meandros das disputas políticas.

\footnotetext{
${ }^{11}$ CHARTIER, Roger. A História Cultural: entre práticas e representações. Tradução de Maria Manuela Galhardo, Lisboa, Difel, 1990, p. 27

${ }^{12}$ CHARTIER, Roger. "O mundo como representação" In Estudos Avançados. São Paulo, v. 5, n. 11, Abril. 1991, p. 183.

${ }^{13}$ BACZKO, Bronislaw. "Imaginação Social”. In: Enciclopédia Einaudi (Anthropos-Homem). Lisboa: Imprensa Nacional/Casa da Moeda, 1985, v. 5, p. 298.

${ }^{14}$ Ibidem, p. 311.
} 
A título introdutório, comentam-se aqui alguns aspectos históricos do período que serão retomados de forma bem mais aprofundada ao longo da tese.

Pode-se afirmar que, em certo sentido, a Segunda Guerra Mundial teve efeitos opostos para Brasil e Argentina. O Brasil, que vivia em plena ditadura do Estado Novo instituída por Getúlio Vargas, viu seu presidente discricionário se enfraquecer, especialmente após a aliança militar com os Estados Unidos, que defendiam enfaticamente a democracia como modelo político. Na Argentina, um grupo militar de tendência fascista, do qual fazia parte o general Juan Domingo Perón, deu um golpe de estado em 1943. Isso explica, em parte, por que esse país foi o último das Américas a romper com o Eixo, mantendo-se neutro no conflito até um mês antes da morte de Adolf Hitler.

Nos meses finais de 1945, a derrubada do Estado Novo trouxe alento àqueles que enfatizavam a importância de um sistema político democrático no Brasil. Naquele ano, foram criados pelo menos três grandes partidos, o Partido Social Democrático (PSD), o Partido Trabalhista Brasileiro (PTB) e a União Democrática Nacional (UDN). Os dois primeiros estiveram mais ligados ao varguismo e à complexa rede de alianças construída por ele. Enquanto o PSD congregava setores da classe média e das elites agrária e industrial apoiadoras do getulismo, o PTB contava principalmente com a adesão de trabalhadores ligados aos sindicatos. De acordo com o historiador Jorge Ferreira, a ala do PTB mais vinculada a João Goulart definia-se pela defesa do "capital produtivo e sobretudo o de origem nacional, a intervenção do Estado nas atividades econômicas e nas relações de trabalho, a ampliação do mercado interno e a elevação do nível de vida dos assalariados". 15

Já a UDN, de especial interesse neste trabalho, surgiu a partir da oposição a Vargas ao congregar muitos críticos do Estado Novo. O partido teve apelo principalmente entre as elites, mas atraiu também parte significativa da classe média urbana e da população rural de regiões dominadas por líderes oligárquicos antigetulistas. Ideologicamente, apresentou como traço central o liberalismo com ênfase no livre mercado, no direito à propriedade privada e em outros direitos individuais. De modo geral, seus correligionários defendiam a democracia e se colocavam contra o fascismo e, principalmente, o comunismo. No entanto, o liberalismo udenista carregava "feição indisfarçavelmente elitista", evidente nas reservas quanto à extensão da

\footnotetext{
${ }^{15}$ FERREIRA, Jorge. O imaginário trabalhista: getulismo, PTB e cultura política popular (1945-1964). Rio de Janeiro, Civilização Brasileira, 2005. p. 124.
} 
participação popular e nos contínuos apelos de alguns de seus membros à intervenção militar. ${ }^{16}$ Explica a socióloga Maria Victoria de Mesquita Benevides:

\begin{abstract}
Em termos gerais, a UDN comportou-se como qualquer partido conservador: contra o voto dos analfabetos, contra as reivindicações trabalhistas (majorações de salários, greves, pactos de ação sindical), contra a extensão das leis trabalhistas no campo. Tratava-se da "eterna vigilância" contra tudo o que pudesse ser interpretado como "subversão", ou como ameaça aos interesses dos proprietários de terras ou de "proletarização" das classes médias. ${ }^{17}$
\end{abstract}

Assim, o partido apresentava-se como liberal e, ao mesmo tempo, expressava posições políticas bastante conservadoras. Crítico do Estado Novo, foi saudado anos depois como o partido da "Revolução de 1964". De acordo com Benevides, esse "liberalismo restrito" udenista estava enraizado na tese elitista de que "o povo jamais será politicamente responsável; no máximo poderá ser 'politicamente educado' ou 'guiado"'. 18

A UDN teve seu primeiro revés em dezembro de 1945, quando seu candidato à presidência, brigadeiro Eduardo Gomes (1896-1981), foi vencido por Eurico Gaspar Dutra, apoiado pelo PSD e PTB. Como ex-ministro do Estado Novo, havia quem esperasse de Dutra um governo de continuidade do programa getulista. Não foi o que aconteceu. Ao longo do mandato, ele aproximou-se dos grupos conservadores, formando uma grande coalizão e entregando a eles três ministérios, enquanto o PTB não dispunha de nenhum. Além disso, 143 sindicatos sofreram intervenções do governo e houve forte alinhamento diplomático com os Estados Unidos no início da Guerra Fria. Em 1947, o Tribunal Superior Eleitoral cassou o registro do Partido Comunista Brasileiro (PCB) e no ano seguinte todos os parlamentares vernelhos perderam seus mandatos.

Nesse período na Argentina, o então coronel Juan Domingo Perón exercia seu primeiro mandato presidencial. Ele se destacara anos antes como um dos principais membros do Grupo de Oficiais Unidos (GOU), que articulou um golpe militar e assumiu o poder em 1943. Na ocasião, vários representantes do novo regime eram adeptos da ideologia nazifascista e simpatizantes do Eixo. Na condição de Secretário do Trabalho e da Previdência Social, Perón estabeleceu aliança com uma ala do movimento

\footnotetext{
16 BENEVIDES, Maria Victoria de Mesquita. A UDN e o udenismo - ambiguidades do liberalismo brasileiro (1945-1965). Rio de Janeiro: Paz e Terra, 1981, p. 247-9.

${ }^{17}$ Ibidem, p. 277-279.

${ }^{18}$ Ibidem, p. 252.
} 
sindical. Ele adotou políticas favoráveis aos trabalhadores assalariados que se assemelhavam às de Vargas, político que Perón afirmou repetidas vezes admirar. A partir da consolidação de leis já existentes e de novas concessões, angariou enorme popularidade.

Enfrentou, porém, fortes adversários internamente (setores das oligarquias tradicionais, grupos empresariais, políticos dos partidos liberais e conservadores, intelectuais e grupos de esquerda) e externamente (governo e empresários norteamericanos).

Em outubro de 1945, Perón, considerado um dos homens fortes do regime do GOU, foi preso por militares receosos com os contínuos protestos que sua atuação vinha provocando. Em reação, no dia 17 daquele mês, uma enorme multidão operária apoiada principalmente pela CGT (Confederación General del Trabajo) concentrou-se em frente à Casa Rosada para exigir sua libertação sob ameaça de greve geral. Livre e ovacionado, o coronel anunciou tempos depois que concorreria às eleições presidenciais do ano seguinte.

Na campanha, marcada por intensa polarização, Perón articulou uma coalizão de forças heterogêneas, que teve como base o Exército, a Igreja Católica, grupos conservadores nacionalistas e trabalhadores, sobretudo aqueles que pertenciam à CGT. A interferência explícita e incisiva dos Estados Unidos no processo político argentino, através da atuação do embaixador norte-americano Spruille Braden, foi habilmente utilizada por Perón, que argumentou que seus concorrentes não passavam de grandes oligarcas e títeres da potência capitalista. A estratégia funcionou e ajudou-o a vencer o pleito com quase $53 \%$ dos votos.

Embora anticomunista, Perón reestabeleceu relações diplomáticas com a União Soviética apenas alguns dias depois de chegar à Presidência. Ele declarou em 1947 a "Terceira posição" da Argentina em relação à Guerra Fria. Buscaria, sobretudo no nível discurso, mostrar distanciamento em relação à política tanto dos Estados Unidos quanto da União Soviética. ${ }^{19}$ Além disso, o Partido Comunista argentino não foi proscrito em nenhum momento. Do ponto de vista da diplomacia norte-americana, o governo peronista passou a ser visto como um "troublemaker". ${ }^{20}$

${ }^{19}$ CAVLAK, Iuri. A política externa brasileira e a Argentina Peronista (1946-1955). São Paulo, Annablume, 2008. p. 45.

${ }^{20}$ Causador de problemas, em uma tradução nossa. Ver: BANDEIRA, op. cit., p. 242. 
Como demonstrou Maria Helena Capelato, foi montada no primeiro mandato (1946-1951) uma ampla e bem articulada estrutura de propaganda oficialista, que incluía controle sobre grande número de meios de comunicação. ${ }^{21}$ Houve também fortalecimento do Poder Executivo, limitação das liberdades políticas que resultaram na prisão de opositores e censura aos meios de comunicação. Em 1947, foi fundado o Partido Peronista, cuja nome já evidencia o processo de centralização de poderes nas mãos do então mandatário da Casa Rosada.

A Argentina possuía muitas reservas, acumuladas em decorrência dos saldos comerciais positivos obtidos durante a guerra. Esses recursos financiaram a política peronista de distribuição de renda e de forte intervenção do Estado na economia. Houve aumento do poder de compra dos trabalhadores, o que gerou grande entusiasmo de parte da população. A empolgação que tomou conta do país nesses primeiros anos fez com que o historiador argentino Félix Luna definisse o período de 1946 a 1949 como a época em que "la Argentina era una fiesta". ${ }^{22}$ Aproveitando-se do bom momento, o peronismo liderou uma ampla reforma da Constituição em 1949 que incorporou direitos sociais e garantiu a Perón ilimitadas tentativas de reeleição.

Enquanto o general Eurico Gaspar Dutra esteve na Presidência, a diplomacia argentina tentou em inúmeras ocasiões uma aproximação maior com o Brasil, seu terceiro maior parceiro comercial. O resultado, no entanto, ficou aquém do esperado. Ainda que Dutra, Perón e Evita tenham se encontrado em Uruguaiana-RS, em 1947, não existiram grandes avanços em termos diplomáticos e políticos no sentido de estreitamento de laços entre os dois países. De acordo com o historiador Iuri Cavlak, a política externa dutrista, ao incorporar diretrizes de Washington, adotou uma postura de obstrução à integração regional que dificultou o fechamento de acordos de cooperação. ${ }^{23}$ Além disso, tais iniciativas eram rejeitadas pela UDN e por um setor do próprio Itamaraty, órgão com quadros politicamente conservadores que, geralmente, não viam com bons olhos a experiência social peronista.

Por conta disso, era grande a expectativa argentina em torno da vitória de Vargas nas eleições presidenciais de outubro de 1950. Esperava-se uma guinada nos rumos da política externa brasileira. Na ocasião, a imprensa portenha controlada pelo governo fez

\footnotetext{
${ }^{21}$ CAPELATO, 2009, op. cit.

22 LUNA, Félix. Perón y su tiempo: la Argentina era una fiesta - 1946-1949. Buenos Aires: Sudamericana, 1986, p. 20.

${ }^{23}$ CAVLAK, op.cit., p. 56-57.
} 
explícita campanha a favor dele e publicou duras críticas à diplomacia de Dutra. ${ }^{24}$ Vargas, homem de fronteira, retribuiu retoricamente apoiando a ideia de que as ilhas Malvinas deveriam pertencer à Argentina. ${ }^{25}$ Essa troca de gentilezas, aliada às visitas de líderes do PTB ao país vizinho, acabaram por levantar suspeitas de que a candidatura estivesse recebendo dinheiro de Perón. João Goulart (Jango), então deputado estadual do PTB, era apontado como um dos intermediadores do suposto financiamento.

Lançado pelo PTB e com apoio de uma parte do PSD, Vargas foi eleito presidente com pouco mais de $48 \%$ dos votos válidos. Saiu derrotado novamente o candidato da UDN, brigadeiro Eduardo Gomes. Após o resultado, a oposição tentou impedir a posse de Vargas a partir de uma interpretação estrita da Constituição de 1946, que supostamente exigiria a maioria absoluta dos votos válidos. Em janeiro de 1951, o argumento foi rejeitado pelo Tribunal Superior Eleitoral. No entanto, a tentativa de impugnação mostrou a disposição das oposições em fazer implacável campanha contra o novo governo. ${ }^{26}$

Nos anos seguintes, uma parte da UDN tornou-se cada vez mais intransigente. Essa ala mais agressiva ficou conhecida como a "Banda de Música". Um trecho de editorial assinado por Carlos Lacerda ilustra bem o ponto de vista do grupo. Nas suas palavras: "O senhor Getúlio Vargas, senador, não deve ser candidato à presidência. Candidato, não deve ser eleito. Eleito, não deve tomar posse. Empossado, devemos recorrer à revolução para impedi-lo de governar". ${ }^{27}$

Boa parte dos meios de comunicação, que tinham sido censurados durante o Estado Novo, também adotou postura muito crítica em relação ao novo presidente. De acordo com Maria Celina Soares D'Araújo, o governo Vargas teve iniciativas bastante tímidas em relação à publicidade oficial, pois a oposição enxergava nesse tipo de gasto público um "resquício imoral do arbítrio estado-novista". ${ }^{28}$ Excetuando-se o apoio do jornal Última Hora, o "desarmamento publicitário do Governo" era evidente. Declara a autora:

\footnotetext{
${ }^{24}$ Em editorial não assinado publicado no Correio da Manhãa, um dos diários mais lidos do Rio de Janeiro, a interferência argentina foi duramente criticada: "Não contando com a imprensa democrática do Brasil, o getulismo desforra-se nas loas e fanfarras com que a imprensa escrava de Buenos Aires está saudando os seus sucessos eleitorais, não contente da grosseria com que, muito antes do pleito, vinha procurando intervir numa campanha política [presidencial] que só dizia respeito aos brasileiros". Ver: Grosseria e insolência [editorial]. Correio da Manhã, Rio de Janeiro, 10 de outubro de 1950. p. 1.

${ }^{25}$ CAVLAK, op. cit., p. 136

${ }^{26}$ D'ARAÚJO, Maria Celina Soares, O Segundo Governo Vargas, 1951-1954. Rio de Janeiro: Zahar, 1982. p. 122-129.

${ }^{27}$ LACERDA, Carlos. “Advertência oportuna” In Tribuna da Imprensa, 1/6/1950, p. 4

${ }^{28}$ D’ARAÚJO, op.cit., p. 161.
} 
Os grandes jornais da época, por suas posições antigetulistas e antigovernistas, desempenham papel fundamental na divulgação de críticas acirradas contra as decisões e indecisões que emanam das esferas governamentais. [...] Ao nível ideológico, é através da grande imprensa que se expressam fundamentalmente as críticas dirigidas à política de Vargas. É através dela que as insatisfações e divergências dos grupos dominantes ganham ressonância, transformando os grandes jornais em núcleos poderosos da resistência ao Governo. ${ }^{29}$

Com a vitória de Vargas, representações sobre uma possível aliança entre trabalhistas e justicialistas tornaram-se constantes. Durante todo seu segundo governo, Vargas teve que conviver com a suspeita de conspirar secretamente com o presidente argentino. Sobre o dano causado por tais desconfianças, Lourival Fontes, chefe do Gabinete Civil da Presidência da República na época, comentou: "De todos os argumentos usados contra Getúlio Vargas, durante seu último governo, poucos alcançaram a repercussão do affaire Perón [...]". ${ }^{30}$

A conjuntura, ao menos em teoria, favorecia maior aproximação entre Brasil e Argentina. Além das semelhanças de estilo político com Perón, o político gaúcho não manteve uma política de alinhamento com os Estados Unidos tão forte quanto o mandatário anterior. ${ }^{31}$ Ao mesmo tempo, a crise econômica que se abateu sobre a Argentina no início dos anos de 1950 fez com que Perón adotasse uma postura menos crítica em relação a Washington. Necessitando de investimentos e empréstimos externos, o regime justicialista renunciou parcialmente à orientação nacionalista no plano econômico. $^{32}$

Desde o início da década de 1950, Perón insistia publicamente na ideia do Pacto $A B C$, uma iniciativa de integração econômica composta por Argentina, Brasil e Chile. De acordo com ele, os três países tinham economias complementares e sua união seria a única forma de contrabalançar o futuro ataque das superpotências às nações detentoras de amplos recursos naturais.

\footnotetext{
${ }^{29}$ Ibidem, p. 25.

${ }^{30}$ CARNEIRO, Glauco. Lusardo: o último caudilho: entre Vargas e Perón. Vol. 2. Rio de Janeiro: Nova Fronteira, 1978. p.409.

${ }^{31}$ Isso é facilmente perceptível em atos como a criação da Petrobrás, a lei de remessa de lucros que prejudicava os interesses das multinacionais e o projeto de criação da Eletrobrás.

32 Foram tomadas medidas, por exemplo, que facilitavam a remessa de lucros das multinacionais e o investimento estrangeiro na área de extração de petróleo. Em algumas ocasiões, a contradição em relação ao antigo discurso oficial foi apontada por membros do seu próprio partido. Foi o que ocorreu, por exemplo, nas manifestações públicas de descontentamento com a possibilidade, cogitada por Perón, de mandar tropas para a Guerra da Coreia em apoio aos norte-americanos. Ver: CAVLAK, op. cit., p. 48 e BANDEIRA, op. cit., 257-258.
} 
Vargas tinha consciência de que um encontro com o líder platino daria munição à oposição interna. De acordo com o embaixador João Batista Lusardo, Perón teria tentado se encontrar Vargas ao menos cinco vezes, inclusive na ocasião de sua posse. Nesses momentos, porém, o líder brasileiro fez entender gentilmente que, dada a forte oposição que enfrentava, não seria aconselhável uma reunião entre eles. ${ }^{33}$ Irritado com as seguidas rejeições, o chefe da Casa Rosada teria questionado certa vez o diplomata brasileiro: "Por acaso eu sou um leproso?".34

Naquele momento, Perón já fora reeleito para um segundo e inconcluso mandato (1951-1955). A lembrança dos tempos de prosperidade, a intensa propaganda política e as alterações na legislação eleitoral garantiram a ele uma vitória relativamente tranquila, com $62 \%$ dos votos. O Partido Peronista ampliou ainda mais seu domínio político ao conquistar todos os governos provinciais e todas as vagas no Senado, além de garantir controle ainda maior sobre a Câmara dos Deputados. Nas palavras do sociólogo argentino Juan Carlos Torre, houve nesse período um processo "sistemático [de] atrofiamento do pluralismo político e das liberdades públicas". 35

Embora não tenha participado diretamente desse processo eleitoral, Eva Perón foi especialmente importante. Em 1947, uma campanha encabeçada por ela havia conseguido a aprovação do voto feminino no país. Perón esperava lançá-la como candidata a vice-presidente, mas o diagnóstico de câncer e a forte resistência ao seu nome entre os militares acabaram impedindo que a ideia se concretizasse.

A controvérsia evidenciava que as relações entre o coronel e a alta oficialidade das Forças Armadas não iam tão bem quanto antes. A própria Igreja, que fora um dos pilares do governo, estava em rota de colisão com o justicialismo. Nesse sentido, é reveladora que a tentativa da CGT de beatificar Evita após sua morte em 1952 tenha sido energicamente rejeitada pela alta hierarquia eclesiástica do país. Apesar dos esforços do governo, a oposição continuou existindo e tornou-se cada vez mais hostil e recalcitrante à intensa propaganda nos meios de comunicação e nas escolas.

Enquanto isso, no Brasil, as acusações da imprensa a respeito de conluios entre trabalhistas e peronistas se ampliaram a partir da indicação de João Goulart para Ministro do Trabalho em junho de 1953. Difundiu-se à exaustão a ideia de que ele buscava implantar uma "república sindicalista" no Brasil. Desse ponto de vista, o jovem

\footnotetext{
${ }^{33}$ CARNEIRO, op. cit., p. 442-443.

${ }^{34}$ Apud NETO, op. cit., p. 263.

35 TORRE, Juan Carlos, "Introducción a los años peronistas" In Juan Carlos Torre (dir.) Nueva Historia Argentina. Los años peronistas (1943-1955), Buenos Aires, Sudamericana, 2002, Tomo VIII, p. 53.
} 
líder gaúcho estaria se aproximando dos sindicatos para construir uma base eleitoral que ampliasse o poder dos trabalhistas no Congresso. Assim, seria possível reformar a Constituição, criar a possibilidade de reeleição e garantir a continuidade dos petebistas no palácio do Catete. Grosso modo, seria essa a estratégia para criar uma "ditadura sindicalista" nos moldes daquela que, alegava a oposição, havia na Argentina. Esclarece Jorge Ferreira:

\begin{abstract}
O fantasma argentino, para as oposições brasileiras, era verdadeiramente ameaçador. Afinal, sem golpes de Estado, Perón ascendera ao poder pela mobilização do movimento sindical e pelo voto dos trabalhadores. O seu partido, com vitórias eleitorais seguidas, tinha maioria no parlamento e os adversários, insistindo no palavreado antiperonista, resistiam para não desaparecer do cenário político. Com o respaldo das Forças Armadas, amplo apoio popular e praticamente imbatível nas urnas, o líder argentino passou a exercer poderes ditatoriais, mesmo que em um regime formalmente democrático. $^{36}$
\end{abstract}

A situação se complicou em 1954 quando, a partir da divulgação de um discurso secreto de Perón, Vargas passou a ser acusado de firmar acordos sigilosos com a Argentina sem consentimento do Congresso. Os insistentes rumores em torno do Pacto $A B C$ dificultaram a aproximação entre os países e deram origem a um processo de impeachment do presidente brasileiro, que foi rejeitado no Congresso em junho de 1954. Para a historiadora Mônica Hirst, “em nenhum momento da história contemporânea brasileira as relações com a Argentina geraram tanta mobilização política interna". 37

A situação de Perón não parecia mais fácil. Além de enfrentar dificuldades econômicas, o governo viu setores das Forças Armadas e da Igreja Católica se juntarem à oposição radical, que vinha resistindo às tentativas de controle do governo. ${ }^{38}$ Os conflitos se intensificaram bastante no ano de 1955. Em junho, edifícios do centro de Buenos Aires foram bombardeados, numa tentativa frustrada de militares de assassinar o presidente que resultou na morte de 364 pessoas. O "Massacre da Praça de Maio" ampliou ainda mais a polarização ideológica e teve como reação o incêndio de várias igrejas do centro da Capital, estimulado discretamente por forças peronistas.

\footnotetext{
${ }^{36}$ FERREIRA, 2005, op. cit., p. 127.

${ }^{37}$ HIRST, Monica. "Vargas y Perón. Las relaciones argentino brasileñas" In Todo es Historia, no. 224, Buenos Aires, deciembre 1985, p. 26.

${ }^{38} \mathrm{O}$ fortalecimento da oposição na sociedade argentina veio acompanhado da ampliação das dificuldades econômicas, principalmente a partir de 1952. Para fazer frente à inflação e ao déficit fiscal, o governo anunciou o II Plano Quinquenal, que incluía a diminuição dos investimentos públicos, o aumento dos impostos, o congelamento dos salários e o controle de preços. Nos discursos de Perón, o racionamento de carne e de farinha de trigo foi justificado pela necessidade de sacrifícios diante dos novos tempos.
} 
Finalmente, em 16 de setembro, uma nova rebelião, liderada principalmente pelo Exército e pela Marinha, derrubou Perón. Nos anos seguintes, medidas autoritárias buscaram em vão banir qualquer referência ao justicialismo do sistema político argentino.

"Quien gobierna al Brasil? En estos momentos gobierna el Brasil, en múltiples aspectos, la prensa". 39 A frase é do embaixador argentino no País, Juan Isaac Cooke, em um informe reservado de janeiro de 1953. No documento, o diplomata mostrava-se surpreso com o poder dos jornais locais. Ele os criticou:

Ser proprietário de um jornal nesse país significa tanto como ser "gângster" e ter nas mãos uma metralhadora Thompson para se impor aos pacíficos e desarmados cidadãos na oportunidade de um assalto. Mas o mais grave é que o "gângster" jornalístico no Brasil se impõe não somente ao cidadão, senão ao governante mais poderoso. ${ }^{40}$

Embora se deva ponderar tais comentários, é evidente a grande influência política exercida pelos meios de comunicação escritos no período. Para ficar em apenas um exemplo, basta lembrar seu papel fundamental na crise que culminou no suicídio de Vargas. Explica a historiadora Alzira Alves de Abreu,

Os jornais [dos anos 1950] eram partidários, ou seja, refletiam os interesses ideológicos dos partidos políticos, embora não fossem sustentados financeiramente pelos partidos. [...] Os jornais gravitavam em torno da personalidade do dono ou do redator-chefe: falava-se no jornal do Lacerda (Tribuna da Imprensa), do dr. Roberto Marinho (O Globo), do Macedo Soares (Diário Carioca), do Paulo Bittencourt (Correio da Manhã) etc. ${ }^{41}$

Ao analisar a imprensa liberal, Maria Helena Rolim Capelato teceu considerações bastante pertinentes a respeito da natureza política de tais jornais. De acordo com a autora, esses periódicos eram opinativos e atuavam intensamente na vida política nacional. Ideologicamente, tendiam a se autorepresentar como "intérpretes das

\footnotetext{
39 ALMEIDA, 2005, op. cit., p. 80.

${ }^{40}$ Ibidem, p. 82.

${ }^{41}$ ABREU, Alzira Alves de. "Revisitando os anos 1950 através da imprensa". In: BOTELHO, André. $O$ moderno em questão. A década de 1950 no Brasil. Rio de Janeiro, Topbooks, 2008, p. 221.
} 
Luzes", dotados da missão de expressar e interpretar objetivamente as vontades da opinião pública. Segundo a autora, a imprensa:

[...] se apresentava aos leitores como expressão dos altos valores eternos, universais e, consequentemente, como apartidária, apolítica e impessoal. Envolta nessa armadura, podia se lançar com suas poderosas armas, na luta política, anunciando-se como defensora da verdade, ideal supremo das Luzes. $^{42}$

O ideal de objetividade acabava por ocultar os interesses econômicos, sociais e políticos que movem os meios de comunicação. Ou seja, "o artifício da impessoalidade prestava-se ao ocultamento do poder pessoal". ${ }^{43}$ Portadores desse ideal, os jornalistas acreditavam e faziam acreditar que transmitiam "não só informações, mas também ideias verdadeiras". ${ }^{44}$ De acordo com Capelato, não ficava explícito que o: “[...] jornalista determina o que vale a pena ser visto e como deve ser visto. Nesse procedimento se identifica com o fotógrafo: ambos veem o real à sua maneira mas o resultado que apresentam aparece como expressão exata do real". ${ }^{45}$

Nesse sentido, os periodistas tendiam a se colocar como "seres privilegiados", capazes de representar a opinião pública (vox populi). A partir dessa perspectiva, arrogavam o direito de denunciar e combater os abusos dos governos e, ao mesmo tempo, formar a opinião pública, de acordo com seus valores e interesses. Essa última preocupação estava especialmente presente nesses jornais liberais, que se dispunham a controlar a "patuleia exaltada". Em razão disso, a autora denuncia sua postura autoritária:

[...] o ideal liberal veiculado pela imprensa faz supor que a luz [...] não chega diretamente ao "homem comum"; somente as "elites" têm olhos para ver e, por este motivo, se configuram como intermediárias no processo de formação da consciência.

[...] Ao se atribuírem a missão de condutores e formadores das consciências, arrogam-se o direito de falar em nome da "massa inculta" sob alegação de que ela é incapaz de produzir um discurso próprio.

[...] ao falar pelos outros, os que se diziam intérpretes de um poder impessoal (poder das Luzes) procuravam tornar respeitáveis e aceitas as decisões emanadas de seu arbítrio e ditadas por seus interesses particulares. Assim, ficavam legitimadas as ideias e a prática política dos jornais que conduziam. ${ }^{46}$

\footnotetext{
${ }^{42}$ CAPELATO, Maria Helena Rolim. Os Intérpretes das Luzes: Liberalismo e Imprensa Paulista (19201945). Doutorado em História Social. Universidade de São Paulo, USP, 1986. p. 68.

${ }^{43}$ Idem

${ }^{44}$ Ibidem, p. 56.

${ }^{45}$ Ibidem, p. 128.

${ }^{46}$ Ibidem, p. 126.
} 
Tendo em vista essas questões, evitou-se aqui cair na visão ingênua da imprensa como espelho da opinião pública. Essa ideia, como alerta Maria Helena Capelato, mascara os interesses de muitos meios de comunicação, que aparecem para seu público com uma aura de neutralidade que, a rigor, não existe.

Analisam-se nesta tese um jornal diário e uma revista ilustrada, ambos de tendência política liberal-conservadora. Foram selecionados a revista semanal ilustrada O Cruzeiro (1938-1975) e o jornal Tribuna da Imprensa (1949-2008), publicados na então capital federal. De acordo com documento da embaixada argentina no Rio de Janeiro, o jornal de Carlos Lacerda e a ampla rede de publicações de Assis Chateaubriand (Diários Associados) eram justamente aqueles que praticavam o antiperonismo de forma mais "radical e permanente". ${ }^{47}$ Abordam-se a história e as peculiaridades desses veículos de comunicação nos primeiros capítulos da tese. Existiram outras vozes antiperonistas importantes, especialmente o diário carioca Correio da Manhã (1901-1974) e o jornal paulistano O Estado de S. Paulo. Embora eles não tenham sido estudados em profundidade, foram frequentemente citados pelos meios de comunicação escolhidos, e por isso suas posições serão comentadas brevemente ao longo do trabalho.

As revistas semanais ilustradas costumavam veicular reportagens mais amplas sobre a política argentina e faziam uso, em boa parte dos casos, de um grande número de imagens. ${ }^{48}$ Dada a complexidade e especificidade da análise das fotografias, esse aspecto das fontes históricas não foi analisado nesta tese, mas poderá ser contemplado em trabalhos acadêmicos futuros.

De modo geral, a imprensa liberal-conservadora brasileira costumava defender a liberdade de expressão e outros valores caros ao liberalismo clássico, como o respeito à propriedade privada e a não interferência do Estado na economia. Dado o passado

\footnotetext{
${ }^{47}$ ALMEIDA, 2005, op. cit., p.149.

${ }^{48}$ As revistas semanais de variedades surgiram no Brasil no início do século XX e atingiram seu apogeu com O Cruzeiro nos anos 1950. Tânia Regina de Luca comentou algumas de suas principais características: "Com apresentação cuidadosa, de leitura fácil e agradável, diagramação que reservava amplo espaço para as imagens e conteúdo diversificado, que poderia incluir acontecimentos sociais, crônicas, poesias, fatos curiosos do país e do mundo, instantâneos da vida urbana, humor, conselhos médicos, moda e regras de etiqueta, notas policiais, jogos, charadas e literatura para crianças, tais publicações ofereciam um lauto cardápio a diferentes leitores, justificando o termo de variedades. Pode-se supor que tal uso cumpria função estratégica: diante do relativamente minguado público leitor/consumidor, o sucesso do negócio revista dependia de se conseguir ampliar ao máximo os possíveis interessados, daí o recurso a uma rubrica ampla, que permitia incluir de tudo um pouco". Ver: LUCA, op. cit., p. 121.
} 
autoritário de Getúlio, havia certo ressentimento em relação aos tempos de censura e de intimidação por parte do Departamento de Imprensa e Propaganda (DIP).

Por outro lado, esses periódicos frequentemente adotavam uma postura fortemente crítica em relação a reformas sociais, pois, nas palavras de Jorge Ferreira, tendiam a identificar "os direitos sociais dos trabalhadores, bem como os perigos de sua extensão e ampliação, como uma ameaça à ordem liberal". ${ }^{49}$ Assim, não viam com bons olhos também a postura nacionalista e antiestadunidense do peronismo, e, principalmente, a mobilização das massas urbanas feita por intermédio dos sindicatos. Nesses meios de comunicação, varguismo e peronismo eram constantemente associados.

Pode-se dizer que havia alguma identificação ideológica entre tais periódicos e a UDN, mas essa relação nem sempre foi direta. Os meios de comunicação pertencentes aos Diários Associados vinculavam-se apenas aos interesses de seu proprietário, que acabavam por coincidir frequentemente com os da agremiação. Do mesmo modo, Tribuna da Imprensa, de propriedade de um dos principais líderes do partido, pode ser considerado um órgão oficial apenas do lacerdismo e não do udenismo como um todo.

Ao eleger esse objeto de pesquisa, tem-se em mente a observação do historiador francês Jean François Sirinelli, para quem "jornais e revistas não são obras solitárias”, mas "empreendimentos que reúnem um conjunto de indivíduos, o que os torna projetos coletivos, por agregarem pessoas em torno de ideias, crenças, e valores que se pretende difundir a partir da palavra escrita". Ou seja, os órgãos de imprensa são atores fundamentais nas disputas políticas, pois tendem a ser um "ponto de encontro de itinerários individuais unidos em torno de um credo comum". ${ }^{50}$ Assim, embora os periódicos selecionados fossem compostos por diversos jornalistas e articulistas que tinham visões políticas múltiplas, não se pode deixar de supor certa comunhão ideológica mínima entre aqueles que integravam tais meios de comunicação.

Ainda que a imprensa seja a principal fonte desta tese, foram consultados eventualmente outros tipos de documentação, como os livros de memórias e depoimentos de João Batista Lusardo ${ }^{51}$, João Neves da Fontoura ${ }^{52}$, Pedro Aurélio de

\footnotetext{
${ }^{49}$ Ver: FERREIRA, Jorge. O nome e a coisa: o populismo na política brasileira In: FERREIRA, Jorge (Org.). O populismo e sua história: debate e crítica. Rio de Janeiro: Civilização Brasileira, 2001, p. 118. ${ }^{50}$ Apud LUCA, Tania Regina de. "História dos, nos e por meio dos periódicos". In: PINSKY, Carla Bassanezi (org.). Fontes históricas. São Paulo: Contexto, 2005, p. 140.

${ }^{51}$ CARNEIRO, op. cit..

52 FONTOURA, João Neves da. Depoimentos de um ex-ministro (peronismo - minerais atómicos política externa). Rio de Janeiro, Organização Simões Editora, 1957.
} 
Góes Monteiro ${ }^{53}$, Carlos Lacerda ${ }^{54}$, Samuel Wainer ${ }^{55}$ e de Edmar Morel. ${ }^{56}$ Foram examinadas também algumas cartas trocadas por Vargas com Perón e com funcionários diplomáticos brasileiros, disponíveis no arquivo do CPDOC da Fundação Getúlio Vargas. Ademais, pelo menos duas obras antiperonistas foram publicados em língua portuguesa no período, uma pelo brasileiro Mário de Sousa Martins ${ }^{57}$ e outra pelo exdeputado radical argentino Raúl Damonte Taborda. ${ }^{58}$ Finalmente, uma peça de teatro com críticas ao justicialismo encenada no Rio de Janeiro também foi lida, malgrado não seja possível analisá-la em detalhes ao longo da tese. ${ }^{59}$

Além desta introdução e das considerações finais, a tese divide-se em três capítulos.

No primeiro, resgata-se a oposição ao justicialismo no jornalismo brasileiro no período entre 1945 e 1950. A principal fonte explorada aqui foi a revista semanal ilustrada $O$ Cruzeiro. Analisam-se, principalmente, a associação entre Perón e o regime nazista, principal representação promovida pela oposição nessa fase, e a imagem da política externa peronista como essencialmente imperialista, atribuindo ao líder platino a revivescência de Juan Manuel de Rosas.

O segundo capítulo trata das representações difundidas no período entre 1950 a 1953, ou seja, a partir da campanha presidencial de Vargas até a indicação de João Goulart para ministro do Trabalho, Indústria e Comércio, em julho de 1953. Nessa fase,

\footnotetext{
${ }^{53}$ COUTINHO, Lourival, O General Góes Depõe..., Editora Coelho Branco, 1956.

${ }^{54}$ LACERDA, Carlos. Depoimento. Rio de Janeiro, Nova Fronteira, 1978.

${ }^{55}$ WAINER, Samuel. Minha razão de viver. Rio de Janeiro: Record, 1987.

${ }^{56}$ MOREL, Edmar. Memórias de um Repórter. Record, Rio de Janeiro, 1999.

${ }^{57}$ MARTINS, Mário. Perón: um confronto entre o Brasil e a Argentina. Rio de Janeiro: Edições do Povo, 1950.

${ }^{58}$ TABORDA, Raul Damonte. O caso Perón: uma conspiração internacional. Porto Alegre: Globo, 1954.

${ }^{59}$ A peça Helena fechou a porta estreou em junho de 1950 no Teatro Copacabana, Rio de Janeiro. Escrita por Accioly Netto, diretor da revista $O$ Cruzeiro, e estrelada por Paulo Autran e Tônia Carrero, trazia uma releitura satírica de Lisístrata, de Aristófanes. Em cena, Petrônio, ditador da Lavônia, prepara-se para iniciar uma guerra, mas é contido por sua mulher, uma ex-vedete chamada Helena. Além do tango como música de fundo em algumas cenas, Helena é chamada de Helenita, "a irmã mais velha dos necessitados", aquela que "controlou 32 sindicatos femininos e se tornou um autêntico ídolo popular" ("Helena da Lavônia domina a greve de mulheres de seu paiz" In Diário da Noite, 26 de maio de 1950, p. 4). As referências a Evita e a Perón eram tão claras que suscitaram protestos da embaixada argentina ("Uma peça teatral brasileira comentada pela revista norte-americana Time" In Diário da Noite, Rio de Janeiro, 6 de julho de 1950, p. 4) e dos jornais trabalhistas brasileiros (CARRASCO. Coluna "Cadeira Elétrica". $O$ Radical, Rio de Janeiro, 25 de outubro de 1951, p. 3.). O texto dessa peça está disponível no livro: NETTO, A. Accioly. Três mascaras. Rio de Janeiro, Editora "O Cruzeiro", 1956.
} 
o autoritarismo do regime argentino em relação à imprensa e aos opositores foi especialmente destacado, associando-o à barbárie em contraposição aos valores da civilização ocidental. Inclui-se, a partir daí, o que foi publicado na Tribuna da Imprensa, jornal fundado por Carlos Lacerda no final de 1949, englobando também as charges antiperonistas assinadas principalmente pela cartunista alemã Hilde Weber (1913-1994).

O terceiro capítulo prioriza o período entre 1953 e 1955, em que a Tribuna da Imprensa, em especial, propagandeou muito enfaticamente a ideia de que líderes trabalhistas brasileiros conjuravam com o mandatário argentino para estabelecer uma ditadura semelhante ao justicialismo no País. A expressão "república sindicalista" foi usada com frequência para aludir a esse suposto projeto autoritário. Acompanham-se, sobretudo, duas graves crises políticas no Brasil: a primeira após a divulgação de um discurso secreto de Perón, que culminou em um pedido de impeachment de Vargas no primeiro semestre de 1954; e a segunda, entre setembro e novembro de 1955, quando surgiu a polêmica em torno da carta Brandi.

Por fim, vale destacar que as divisões temáticas dos capítulos não devem ser entendidas como compartimentos estanques. As representações enfatizadas pela imprensa em determinados períodos não foram abandonadas nos anos seguintes. A ideia de que Perón tinha como filiação ideológica o nazismo, por exemplo, foi muito mais presente nos anos imediatamente posteriores à Segunda Guerra. Embora tenha perdido força ao longo do tempo, esse pensamento não despareceu do imaginário político dos anos 1950. Do mesmo modo, a representação de um conluio entre trabalhistas e peronistas era alvo de comentários desde, no mínimo, 1948, mas ganhou enorme publicidade apenas a partir do ano de 1953. 
Perón é um nazista que chegou tarde. Os métodos de sua ação política são nazistas. Mas além de nazista é portenho. Tem um passado histórico de caudilhismo que lhe confere o tom local. O seu ascendente político é Rosas. Subiu com as baionetas. Mas, ao invés de sentar-se sobre elas, sentou-se sobre o proletariado argentino a que os partidos políticos, em dezenas de anos de governo, não souberam dar privilégios ou direitos já conquistados no resto do mundo civilizado. Caudilho tardio, imita os seus avós históricos no culto hipócrita da letra da Constituição. Concentrou o poder em suas mãos, estabelecendo uma ditadura que suprema ironia! - tem formas democráticas. Funciona o Congresso e funcionam os colégios eleitorais, quando é preciso. É este o quadro do nazismo crioulo argentino.

Theóphilo de Andrade ${ }^{60}$

\section{Capítulo 1 \\ Perón, o nazista (1945-1950)}

${ }^{60}$ ANDRADE, Theóphilo de. “As táticas de Perón” In O Cruzeiro, Rio de Janeiro, 09/05/1953. 


\subsection{A campanha antiperonista de $O$ Cruzeiro}

A revista ilustrada $O$ Cruzeiro (1928-1975) teve seu primeiro número publicado em 1928. Até o início dos anos de 1940, porém, era pouco expressiva, além de deficitária. Isso levou seu dono, o empresário da comunicação Assis Chateaubriand (1892-1968), a pensar em fechá-la. A partir de meados dessa década, a situação começou a mudar, principalmente com a contratação de uma grande equipe, que incluía o repórter David Nasser (1917-1980) e o fotógrafo francês Jean Manzon (1915-1990), que foi especialmente importante para a renovação visual da publicação.

Antes, $O$ Cruzeiro tinha um design confuso e sem unidade. Manzon trouxe mudanças radicais e apostou nas reportagens fotográficas (ou fotorreportagens), um estilo no qual as fotografias e as ilustrações prevalecem sobre o texto. De acordo com o ex-repórter da revista Luiz Carlos Barreto, O Cruzeiro tornou-se "o visual da nação" em uma época em que a televisão estava apenas começando. Conta ele: "Nós éramos uma imagem que chegava ao Amazonas, em qualquer lugar, para o sujeito que esperava ver o Carnaval do Rio de Janeiro ou a fotografia do gol da Copa do Mundo". ${ }^{61}$ E acrescenta:

Fazíamos uma revista que, no início da semana, traçava uma síntese do que
tinha acontecido na semana anterior. E isto com uma precisão de análise e,
principalmente, com uma visão fotográfica diferente daquela que os jornais
publicavam sob forma de telegrama ou de reportagens pobres em
informações. $O$ Cruzeiro oferecia, assim, uma informação muito rica,
dinâmica e imediata para os acontecimentos. ${ }^{62}$

Nas palavras de Rafael Baitz, estabelecia-se nas revistas ilustradas "uma relação entre informar e apresentar imagens. Noticiar era mostrar. E as revistas se colocavam como mediadoras, por meio das fotos, entre o leitor e o mundo noticiado". ${ }^{63}$ O novo modelo gráfico era claramente inspirado na revista norte-americana Life e na francesa Paris Match, na qual Jean Manzon havia trabalhado. Junto com essa revolução visual vieram as grandes reportagens assinadas por ele e por Nasser. Após a chegada da dupla, as reportagens passaram a ocupar cerca de $40 \%$ do espaço da publicação, tornando-se o setor mais oneroso e, ao mesmo tempo, mais lucrativo da revista. Aos poucos, eles

\footnotetext{
${ }^{61}$ PEREGRINO, Nadja. A fotografia de reportagem: sua importância na revista O Cruzeiro (1944-1960), Dissertação de mestrado, Escola de Comunicação da Universidade Federal do Rio de Janeiro, Rio de Janeiro, 1990, p. 28.

${ }^{62}$ CADERNOS DE COMUNICAÇÃO. O Cruzeiro - A maior e melhor revista da América Latina, Série Memória, vol. 3, Secretaria Especial de Comunicação Social, Prefeitura Municipal do Rio de Janeiro, Rio de Janeiro, 2002, p. 33.

63 BAITZ, Rafael. Um continente em foco: a imagem fotográfica da América Latina nas revistas semanais brasileiras (1954-1964). São Paulo, Humanitas/História Social-USP, 2003, p. 41.
} 
formariam a dupla mais conhecida do jornalismo naqueles anos. Ainda que não houvesse verificação independente, $O$ Cruzeiro chegou a bater a marca de 720 mil exemplares semanais, número espantoso considerando que a população brasileira era de pouco mais de cinquenta milhões de pessoas no início da década de 1950.

Em consequência dessa grande penetração, O Cruzeiro foi também muito influente politicamente no período. Em depoimento, José Medeiros, fotógrafo da publicação entre 1946 e 1962, assim definiu a posição da revista:

Era acima de tudo uma revista de direita, feita para a classe média consumir. Muitas vezes havia reportagens sobre a fome, a repressão, resultado de interesses particulares de alguns de nós. Eram publicadas porque, em realidade, aquilo era uma bagunça incrível, não tinha um controle organizado. ${ }^{64}$

Suas posições, muitas vezes, oscilaram ao sabor dos interesses de seu temido proprietário, que construiu um enorme conglomerado de empresas jornalísticas, os Diários Associados. Em 1945, por exemplo, Assis Chateaubriand apoiou a redemocratização e a candidatura do brigadeiro Eduardo Gomes (UDN). Com a vitória de Eurico Gaspar Dutra (PSD), porém, passou a respaldar, em linhas gerais, o novo governo (1946-1951).

Nas eleições de 1950, Chateaubriand teve postura ambígua ao apoiar tanto Eduardo Gomes quanto Vargas. Ao longo do tempo, porém, seus jornais e revistas aproximaram-se da linha crítica ao governo. Em 1952, ele próprio elegeu-se senador da Paraíba pelo PSD. Passou a fazer oposição, principalmente em questões como o monopólio estatal do petróleo e o apoio do Banco do Brasil ao jornal Última Hora. Abriu também suas emissoras para Carlos Lacerda, ferrenho crítico do presidente. Assim, não é de estranhar que após o suicídio de Vargas carros de reportagem dos Diários Associados tenham sido atacados e que em Porto Alegre dois de seus prédios tenham sido consumidos pelas chamas. ${ }^{65}$ Alguns dias após a tragédia, Chateaubriand escreveu: "No fundo Getúlio Vargas gostava de mim porque eu era um canalha igual a ele - que sabia que eu manobrava com ele quase sempre com o propósito de enganá-lo, como ele enganava a mim". 66

A respeito do governo peronista, Chateaubriand teve uma postura de constante e profunda crítica, a ponto de um informe da embaixada argentina em Buenos Aires

\footnotetext{
${ }^{64}$ CARVALHO, op. cit, p. 167.

${ }^{65}$ MORAIS, Fernando. Chatô: o rei do Brasil. São Paulo, Cia das Letras, 1994, p. 567.

${ }^{66}$ Ibidem, p. 568.
} 
afirmar que ele nutria verdadeiro ódio pelo país. ${ }^{67}$ Para essa atitude podem ter pesado tanto questões ideológicas quanto financeiras. Vale destacar, especialmente, a proibição da revista na Argentina durante o peronismo. Em uma reportagem, podia-se ler:

O CRUZEIRO, desde as nossas primeiras reportagens, passou a ser uma das revistas condenadas a não atravessar as fronteiras da Argentina. Muitos turistas passaram momentos desagradáveis e tiveram os seus exemplares desta publicação rasgados e atirados fora. Há pouco tempo, as revistas norteamericanas saíram do índex, mas esta continuou. ${ }^{68}$

Sabe-se que, mesmo em língua portuguesa, O Cruzeiro possuía uma tiragem considerável no país vizinho. ${ }^{69}$ Essa vendagem foi uma das razões que levaram Chateaubriand à desastrosa iniciativa de publicar anos depois $O$ Cruzeiro Internacional, edição da congênere em espanhol que circulou pela América Latina entre 1957 e $1965 .^{70}$ Dias após a derrubada de Perón, a revista já comemorava efusivamente: "O Cruzeiro triunfa na Argentina". Nas suas páginas, podia-se ler que em Buenos Aires "a primeira remessa [da revista], reduzida a 15.000 exemplares [...] esgotou-se completamente em menos de 72 horas". 71

Chateaubriand escreveu algumas vezes sobre o peronismo e também discursou a respeito na tribuna do Senado. Em uma dessas ocasiões, um texto de 1949, responsabilizou Perón pela crise econômica que se avizinhava na Argentina e, num grande mosaico ideológico, comparou-o a Hitler, Mussolini e Juan Manuel de Rosas. Ele escreveu:

Com um paroxismo de linguagem hitlerista ou mussoliniana, o ditador argentino tenta reproduzir o fenômeno dos seus dois colegas europeus, que pagaram com a vida as próprias tropelias, perpetradas com o nome de duas grandes comunidades civilizadas. E também Rosas aparece timidamente na fimbria do horizonte iluminado de uma luz baça de querosene, as profecias ingênuas do chefe do executivo do Prata e seus sequazes. O general Perón esquece que chegou atrasado. O último expresso de Berlim partiu e ele esqueceu de tomá-lo. Assediam-no em 1949, os roteiros de totalitarismo nazista que levariam a Alemanha a perdição ontem e à servidão política hoje. Está enfrentando o presidente argentino uma era que não é mais a sua, olvidando que a multidão de imponderáveis, que construíram a grandeza efêmera do tirano alemão foi a mesma que o levou a ruína. Com o grosseiro conteúdo ideológico de uma eloquência frenética o que o general Perón

\footnotetext{
${ }^{67}$ ALMEIDA, 2005, op. cit., p. 150.

${ }^{68}$ NASSER, David e KEFFEL, Ed. "Perón denunciado às Nações Unidas" In O Cruzeiro, Rio de Janeiro, $13 / 9 / 1952$.

69 ACCIOLY NETO, Antonio. O Império de Papel - Os bastidores de O Cruzeiro, Porto Alegre: Sulina, 1998 , p. 159.

${ }^{70}$ Ver: CASADEI, Eliza Bachega. "O sonho imperialista de Assis Chateaubriand na América Latina: ascensão e fracasso de "O Cruzeiro Internacional"". Revista Extraprensa, v. 1, p. 75-87, 2012.

71 “O Cruzeiro triunfa na Argentina” In O Cruzeiro, Rio de Janeiro, 19/11/1955.
} 
revive e uma instituição muito nossa conhecida e que o irredutível caudilhismo americano $[\mathrm{sic}] .^{72}$

Como notou a embaixada argentina, a visão de Chateaubriand decorria, em parte, da defesa apaixonada que ele costumava fazer dos Estados Unidos e da presença do capital estrangeiro na economia brasileira. Ademais, seus negócios dependeriam bastante dos acordos publicitários firmados com grandes empresas multinacionais norteamericanas. Nas páginas de um documento diplomático de 1953, pode-se ler a respeito do conhecido empresário da comunicação: "Sua adesão aos Estados Unidos é tão apaixonada quanto o ódio que tem de nosso país. Com uma tenacidade incoercível, continua pronunciando discursos injuriosos contra o presidente da Argentina". ${ }^{73}$ Em outro documento do mesmo tipo, os diplomatas foram bem mais ácidos, definindo-o apenas como "caluniador e chantagista" ${ }^{74}$ Curiosamente, esses mesmos adjetivos foram usados pelos funcionários da embaixada platina para definir David Nasser, o repórter mais conhecido da revista $O$ Cruzeiro. ${ }^{75}$

De acordo com o levantamento realizado nesta tese, a revista publicou pelo menos 177 reportagens, crônicas e notas sobre a situação argentina entre 1945 e $1955 .{ }^{76}$ Considerando a totalidade de exemplares produzidos do período, em mais de um terço deles Perón e sua atuação tiveram destaque. Esse número parece sintomático da intensa cobertura em torno do tema. Desse material, pelo menos 21 crônicas e/ou reportagens foram assinadas por Nasser.

Para se ter ideia de sua popularidade, uma pesquisa de opinião feita em 1951 com seiscentas famílias concluiu que ele era o jornalista mais lido do Rio de Janeiro naquele momento. ${ }^{77}$ Polêmico e dono de um estilo de escrita peculiar, Nasser possuía um estilo admirado e, ao mesmo tempo, polêmico. Era dotado de uma prosa envolvente, dramática, cheia de adjetivos que, muitas vezes, ressaltava o lado curioso e pitoresco. No entanto, nem sempre se preocupava com a verdade. Muitos detalhes ou, mesmo, matérias inteiras foram inventadas diante de sua máquina de escrever. O jornalista Luiz Maklouf Carvalho, autor de sua biografia, colheu este depoimento de Freddy Chateaubriand, um dos ex-diretores da publicação:

\footnotetext{
${ }_{73}^{72}$ Diário de Notícias, Correio do Povo, $1^{\text {o }}$ de março de 1949. Ver: Apud COSTA, 2004, op. cit., p. 135.

${ }^{73}$ ALMEIDA, 2005, op. cit., p. 87.

${ }^{74}$ Ibidem, p. 181.

${ }^{75}$ Ibidem, p. 183.

${ }^{76}$ A lista das 177 reportagens, notas e crônicas está nos anexos da tese.

${ }^{77}$ RIBEIRO, 2007, op. cit., p. 228.
} 
Os fatos não eram importantes para o David [Nasser], e sim, a criatividade. Ele inventava coisas pra poder valorizar as reportagens. Foi o Manzon que ensinou isso pra ele. Eu era tolerante. Se você é jornalista e quer vender, você tem que ser escroto. É uma palavra meio forte, mas você não pode ter tanto prurido, senão não vende porra nenhuma. E nisso ele era o rei. [...] Eu sabia das sacanagens, das histórias que ele inventava, mas o principal é vender [...] O Manzon tinha escrúpulo zero. Nenhum escrúpulo. E o David, mais ou menos a mesma coisa [...]. Veracidade? Quem está ligando pra ver se é verdade? Era um jornalismo de resultados. Viver de jornal era a coisa mais difícil do mundo. ${ }^{78}$

Segundo Antônio Accioly Netto, ex-diretor da revista, Nasser e Manzon tinham como filosofia a ideia de que "a verdade fica mais verdadeira quando exposta a uma razoável dose de fantasia". ${ }^{79}$ E o próprio David Nasser teria dito em certa ocasião que "a verossimilhança é mais importante do que a verdade". 80

Durante o governo Dutra, Nasser publicou diversas reportagens criticando mordazmente Getúlio Vargas e o Estado Novo. Chegou a defender um golpe de Estado para impedir a posse de Vargas caso ele vencesse as eleições presidenciais. ${ }^{81}$ Afirmava, porém, não guardar ódio pessoal do "velho leão destronado", considerando-o "apenas, inimigo das liberdades democráticas, presidente incapaz, ditador implacável, ébrio do poder, nada mais". ${ }^{82}$ Em outra reportagem, assim o definiu:

Homem frio, calculista, da mais pura massa fascista de que se possa desejar, inimigo das constituições e das leis de controle, ambicioso de força e autoridade, desde cedo compreendeu que a melhor política seria a de dividir para implantar a sua discricionária vontade e as suas decisões pessoais ou ditadas pelos íntimos. ${ }^{83}$

Embora muitos jornalistas que trabalhavam para Chateaubriand tenham criticado duramente Vargas durante seu segundo governo (1951-1954), Nasser absteve-se de atacá-lo como fizera em anos anteriores. Não se conhece ao certo a causa disso. ${ }^{84}$ Sabese, porém, que ele devia grande obediência ao patrão, a quem chamava de "Velho Capitão". Em compensação, Nasser assinou muitas matérias profundamente negativas a respeito do peronismo, nas quais fez, velada ou explicitamente, referências a Getúlio Vargas.

\footnotetext{
${ }^{78}$ CARVALHO, Luis Maklouf. Cobras Criadas: David Nasser e O Cruzeiro. São Paulo, editora SENAC, 2001, p. 127.

${ }^{79}$ ACCIOLY NETTO, op. cit., p. 109.

${ }^{80}$ CARVALHO, op. cit., p. 121.

${ }^{81}$ Ibidem, p. 251.

${ }^{82}$ NASSER, David. “Contrabando no sul” In O Cruzeiro, Rio de Janeiro, 23/11/1946, p. 34, 35 e 44.

${ }^{83}$ NASSER, David. "Getúlio Vargas - flagelo de uma nação" In O Cruzeiro, Rio de Janeiro, 17/06/1950.

${ }^{84}$ CARVALHO, op. cit., p. 251-252.
} 
É possível que algumas razões tenham contribuído mais profundamente para seu exacerbado antiperonismo. A primeira delas foi seu posicionamento político conservador. Crítico de Vargas e dos trabalhistas, Nasser era próximo de Carlos Lacerda e de outros nomes de destaque da direita brasileira. Embora não tenha se arriscado na televisão e tampouco na política institucionalizada, ele circulou livremente entre aqueles que apoiaram o golpe militar de $1964 .{ }^{85}$

Além disso, alegava ter sofrido os efeitos da censura peronista. Em sua vida, ele fez carreira paralela como compositor e foi autor de músicas que se tornaram muito famosas, como "Canta, Brasil!", "Nêga do cabelo duro" e "Adeus ano velho". ${ }^{86}$ Em 1954, Nelson Gonçalves gravou o tango "Carlos Gardel”, escrito por Nasser em parceria com Herivelto Martins. Apesar do enorme sucesso no Brasil, a canção não pôde ser reproduzida nem regravada na Argentina. O motivo, alega uma nota da época, seria retaliação às suas reportagens antiperonistas. A letra do tango, aparentemente, não faz qualquer alusão à política justicialista. ${ }^{87}$

Enfim, pode-se notar que tanto Chateaubriand quanto Nasser possuíam razões ideológicas e financeiras para combater o governo argentino. Conservadores politicamente, ambos eram alinhados à aproximação econômica com os Estados Unidos e criticavam veementemente os regimes antidemocráticos marcados pela mobilização das massas. Ademais, para Chateaubriand a permanência do justicialismo no poder implicava a perda de um mercado editorial em vias de expansão. Já Nasser fora privado dos direitos autorais oriundos da execução e regravação de suas músicas. Assim, com motivações profundas, a revista $O$ Cruzeiro e seus jornalistas promoveram mais do que uma cobertura jornalística. Tratou-se de uma longa e intensa campanha contra a experiência política justicialista.

\footnotetext{
${ }^{85}$ Nasser chegou a fazer parte inclusive de um dos primeiros esquadrões da morte no Rio de Janeiro (Scuderie Detetive Le Coq). Ver: MORAES, Letícia Nunes de Góes. "David Nasser e a conspiração de 1964", in: Revista Tempo Brasileiro, Rio de Janeiro, 158: 137/162, jul.-set., 2004.

${ }^{86}$ Ver: MORAES, Letícia Nunes de. Cotidiano e Política em Carmen da Silva e David Nasser (19631973). Tese apresentada ao Departamento de História da Faculdade de Filosofia, Letras e Ciências Humanas da Universidade de São Paulo, 2007, p. 30-35.

87 ““Carlos Gardel', o tango proibido” In O Cruzeiro, Rio de Janeiro, 19/06/1954, p. 58.
} 


\subsection{Peronismo, o nazismo sul-americano}

Perón venceu Tamborini. Perón venceu Braden. Perón foi vencido facilmente por uma bela atriz de radio-teatro, a dulcíssima Maria Eva Duarte - ou Evita Duarte, nos cartazes das novelas em série. De uma hora para outra, um vulto feminino se projetou de maneira singular na política da América. ${ }^{88}$

Esse foi o primeiro parágrafo que Nasser escreveu sobre o tema. Em junho de 1946, ele e Manzon foram até La Plata, às vésperas da posse presidencial, e assinaram a reportagem “A mulher de Perón”. Como se pode perceber, a matéria utiliza um romance, uma história de interesse humano, como estratégia para fisgar o leitor. Nasser continuou: "Eva - dizem, dizem - sentiu-se dominada pela aparência heroica e bravia, selvagem e fogosa, daquele que - apesar dos anos - era para ela o potro selvagem dos pampas". 89

Apesar desses primeiros parágrafos, Evita quase não apareceu no texto, que enfatizou a complexa situação política argentina. Nesse momento, Nasser fez uma análise relativamente equilibrada do que estava acontecendo no país vizinho. Reconheceu, por exemplo, a legitimidade das últimas eleições. Ele escreveu:

Eleito por impressionante maioria, [Perón] celebrou com seus partidários uma vitória sem dúvida legítima e que representa fielmente a vontade da maioria do povo argentino. Não houve fraude, não houve coação, não houve luta. Os votos foram levados à urna com a opinião dos seus donos. Festejando o triunfo, o vinho correu abundantemente, e se entoou o Hino pelas ruas de todas as cidades argentinas. A atmosfera se descarregou [...]. ${ }^{90}$

Entre outras coisas, Nasser relatou também a boa situação da economia argentina e a enorme popularidade de que gozava o futuro presidente perante uma parte da população. Presente em uma cerimônia pública, descreveu "uma imensa multidão [que] ululava. Quando Perón chegou, o delírio chegou ao paroxismo. Desmaios, gritos, mulheres e homens buscando tocar com as pontas dos dedos o paletó do líder". ${ }^{91}$ Sobre a política externa do governo, que tempos depois causaria tanta polêmica, afirmou:

A política argentina em relação ao Brasil - com Farrel ou com Perón - é de braços abertos. Creem os peronistas que Brasil-Argentina, unidos, contrabalançariam a influência norte-americana no hemisfério. Essa mesma atitude de boa vontade mantém os novos homens do governo argentino frente

\footnotetext{
${ }^{88}$ NASSER, David e MANZON, Jean. “A mulher de Perón” In O Cruzeiro, Rio de Janeiro, 1/06/1946.

${ }^{89}$ Idem.

90 Idem.

${ }^{91}$ Idem.
} 
aos pequenos países vizinhos, inclusive o Chile [...] Tenta-se formar o bloco latino-americano contra a USA [sic]. ${ }^{92}$

Ainda que não apresente ataques explícitos, a reportagem é salpicada por comentários críticos a respeito do autoritarismo do governo de Edelmiro Farell (19441946), membro do GOU. Logo na segunda página, por exemplo, há um quadro negro com a palavra proibido. Ao lado, um esclarecimento: ali deveria constar o flagra de um beijo entre Evita e Perón capturado por Manzon. Os filmes fotográficos, porém, teriam sido confiscados pela polícia argentina, por terem sido feitos sem autorização. Nasser criticou a atitude: "Que coisa tão grave assim era um presidente eleito beijar a esposa? A um ditador, homem forte e sem debilidades sentimentais, estaria mal, porém a um presidente consagrado pela vontade popular, que mal havia?". E concluiu:

Na Argentina, para o cerceamento da liberdade de imprensa todos os métodos alemães e italianos de antes da vitória das forças democráticas são usados com o mesmo vigor com que os três países citados [sic] os empregavam. Não há censura, é verdade. Mas o acesso às fontes de informações é terrivelmente obstado. ${ }^{93}$

Curiosamente, parece haver nessa primeira reportagem uma dissociação entre o discurso textual e o imagético. Isso porque, observadas apenas as fotos e as legendas, a reportagem soa apologética ao peronismo. Nas imagens, Evita aparece glamorosamente bem vestida e com um sorriso educado, tal qual uma jovem atriz de Hollywood. Nas legendas, não há nenhum registro da força política da líder, mas a ênfase em certa doçura. Em uma, pode-se ler: "Estes lindos olhos derrotaram o homem que - para os argentinos - se transformou no maior ídolo popular desde San Martín”. Em outra, destaca-se sua beleza: "Eva Duarte é loura e formosa. Juan Perón amou-a desde o primeiro momento, com todo o ardor de sua alma portenha. - "Argentina e Eva, meus dois amores". Por fim, são apontados outros atributos: "EVA DUARTE, a bela atriz, de um dia para outro, se viu transformada em primeira dama da Argentina. Eva tem classe, tem atitudes distintas, e é inteligente". ${ }^{94}$

Um ano depois, ao cobrir o encontro entre Dutra, Perón e Evita para a inauguração de uma ponte em Uruguaiana, o jornalista Geraldo de Freitas destacou o bom clima do evento, malgrado este não ter sido mais do que uma "simples cerimônia

\footnotetext{
92 Idem.

93 Idem.

${ }^{94}$ Idem.
} 
inaugural" sem "as esperadas e sensacionais declarações dos três presidentes [sic], em conjunto, a respeito da política internacional". Ainda assim, ele escreveu em tom otimista: "Felizmente nas Américas não desceu sobre os corações, como capas de chumbo, a desconfiança e o medo, que erguem fortalezas nas fronteiras, ao invés de estradas e pontes". 95

Em 1947 também, Jean Manzon cobriu a Conferência Interamericana para Manutenção da Paz e Segurança no Continente, realizada no Rio de Janeiro. Repleta de fotografias e com poucos textos, a reportagem "Os descamisados" destacou sobretudo dois líderes da delegação argentina: o ministro das Relações Exteriores, Atilio Bramuglia, e Evita. Embora as fotos denotem novamente glamour e elegância, as legendas alfinetam o regime, que teria vindo com a maior bagagem entre as comitivas, com "quatro caminhões conduzindo dezenas e dezenas de malas". Essa dissociação entre foto e legenda trazia uma mensagem ambígua. Enquanto as imagens mostram luxo e sofisticação, outra legenda indicava uma pequena provocação à hipocrisia do regime: "ESTES são os descamisados do General Perón. Pouco importa o aprumo que envergam o "smoking" e a casava, a riqueza e a variedade do guarda-roupas, o brilho e a "finesse" das "troilettes" femininas. Eles são os descamisados". Novamente, Evita também recebeu muitos elogios. Foi chamada de "o mais convincente dos Embaixadores de Perón [...] e o polo de atração, o ímã, que galvaniza a dedicação dos trabalhadores argentinos ao seu chefe [...]. Ela, hoje, é a alma dos descamisados". 96

Mais alfinetadas foram dadas na reportagem de Samuel Wainer, que anos depois fundaria o jornal varguista Última Hora. Ele destacou que a coragem da "República Milionária e Descamisada do General Perón" para provocar a "nação mais poderosa da Terra" (Estados Unidos) se devia ao controle do petróleo exercido pelo estado. Defensor declarado da intervenção pública na questão, o jornalista apontou a importância do general argentino Enrique Mosconi para a construção da estatal YPF (Yacimientos Petrolíferos Fiscales). Embora visse a atuação argentina no assunto como modelo, ele não deixou de ressaltar o autoritarismo daquele governo: "Sem ele [petróleo], Perón seria mais um desses caricatos caudilhos sul-americanos, que vivem a falar em

\footnotetext{
${ }^{95}$ FREITAS, Geraldo de e REGATO, Angelo. "Novas pontes ligam a América" in O Cruzeiro, Rio de Janeiro, 14/06/1947, p. 56-62.

${ }^{96}$ MANZON, Jean. "Os descamisados" In O Cruzeiro, Rio de Janeiro, 6/09/1947, p. 9-15.
} 
soberania, estão sempre envoltos na bandeira da pátria e divertem-se com imponentes desfiles militares". 97

Apesar de algumas críticas como essa, confirma-se a impressão do historiador Marcelo Gonzalez da Costa que viu em Perón e Evita, especialmente nessa primeira fase, um "bom produto jornalístico, o que demonstra a proliferação de notícias e as manchetes contendo seus nomes" $" 98$. Com grandes reservas financeiras e enorme apoio popular, o governo argentino chamava atenção por sua rebeldia em relação aos Estados Unidos e por ter uma mulher considerada bonita dividindo informalmente a condução do país. Notadamente, as fotografias em O Cruzeiro parecem sutilmente positivas ao peronismo, incorporando aparentemente um pouco da intensa propaganda oficial. Esse tom prevaleceu por algum tempo à revelia das agências de notícias internacionais, especialmente as norte-americanas, que desde a Segunda Guerra transmitiam telegramas constantes com denúncias a respeito do autoritarismo do regime e de suas ligações com a Alemanha nazista.

Embora $O$ Cruzeiro, grosso modo, destacasse cronistas políticos nacionais, a revista publicou, a partir de 1947, a tradução semanal de uma coluna sobre política internacional assinada por Drew Pearson (1897-1969), jornalista bastante influente nos Estados Unidos. Alinhado com a tendência geral da cobertura norte-americana, a coluna "Carrossel do Mundo" veiculava constantes críticas ao governo argentino. Pearson via o presidente platino como o "führer de Buenos Aires",99, que estaria buscando criar um sistema totalitário por meio de sua "Gestapo peronista". ${ }^{100}$ Nesse sentido, denúncias de

\footnotetext{
97 WAINER, Samuel. "Óleo para a grande aventura do general Perón” in O Cruzeiro, Rio de Janeiro, 10/05/1947, p. 34.

${ }_{98}$ Marcelo Fernando Gonzalez da Costa fez interessante análise a respeito da repercussão da política externa do primeiro mandato de Perón (1946-1952) em dois jornais conservadores de Porto Alegre, Correio da Manhã e o Diário de Notícias. De acordo com ele, reconhecem-se três fases da imprensa gaúcha. Na primeira, de maio de 1946 a fevereiro de 1947, os jornais retratavam o governo Perón de forma negativa, como mera continuidade do Grupo de Oficiais Unidos, que governou a Argentina entre 1943 e 1946. A partir de 1947, expressaram uma "percepção política positiva”, que teve seu ápice nas notícias sobre o encontro entre Dutra, Perón e Evita na cidade gaúcha de Uruguaiana, em maio daquele ano. Finalmente, o terceiro período (maio de 1948 a 1952) foi marcado pelo recrudescimento das críticas, marcadas, em sua maioria, pela oposição dos jornalistas brasileiros à repressão aos meios de comunicação no país vizinho, processo que atingiu seu ápice com o fechamento arbitrário de La Prensa, em 1951. De acordo com o autor, os periódicos portoalegrenses reproduziam, com frequência, material profundamente antiperonista transmitido pelas agências de notícias norte-americanas. Para Costa, "as representações da política externa argentina ficaram "contaminadas" com as repercussões de uma política interna repressiva e autoritária” (p. 152). Ver: COSTA, Marcelo Fernandes González da. As repercussões da política externa Argentina no primeiro Governo Perón (1946-1952) na imprensa Sul-Rio-Grandense. Dissertação de mestrado, São Leopoldo, Universidade do Vale do Rio dos Sinos (UNISINOS), 2004.

${ }^{99}$ PEARSON, Drew. "Terror em Buenos Aires" In O Cruzeiro, Rio de Janeiro, 26/6/1948, p. 24

${ }^{100}$ Idem.
} 
diferentes tipos foram publicadas contra o "caudilho" "101, que assolava "a nação menos democrática do continente". ${ }^{102}$

Ao auxiliar Higino Morínigo, "o carniceiro do Paraguai"103, na guerra civil daquele país (1947), Perón estaria buscando transformar aquele país em colônia. ${ }^{104} \mathrm{Na}$ mesma direção, a proposta de criação de um bloco latino-americano foi anunciada como uma estratégia justicialista para dominar a América. ${ }^{105}$ Em consonância com a visão do Departamento de Estado, Pearson via Perón como um líder que, ao contrariar abertamente as diretrizes de Washington, favorecia amplamente o fortalecimento dos comunistas na América do Sul. ${ }^{106}$

Chama atenção também nesse material a grande distância que parece separar algumas análises de Drew Pearson da realidade latino-americana. Para ficar em apenas dois exemplos, ele anunciou em 1947 a ocorrência de um golpe palaciano secreto que supostamente transformara Perón em virtual prisioneiro dos militares ultranacionalistas. ${ }^{107}$ Dois anos depois, comentou que a visita de Dutra a Washington poderia dar início a uma revolução no Brasil liderada pelo "ex-ditador Getúlio Vargas e o esperto comunista Luís Carlos Prestes”. Ressabiado, Dutra estaria, inclusive, "preparando-se para ficar nos Estados Unidos, se necessário". ${ }^{108}$ Ao menos nessas duas ocasiões, Pearson errou feio.

Possivelmente contaminada pelas poderosas agências de notícias norteamericanas, a abordagem de $O$ Cruzeiro começou a mudar profundamente. A partir de 1948, nenhuma matéria positiva sobre a experiência justicialista foi mais publicada. Grosso modo, a Argentina passou a ser descrita como um regime totalitário, nos moldes nazistas, que teria ímpeto imperialista ao buscar a ampliação do seu domínio na América do Sul. Esse alegado expansionismo será analisado um pouco mais adiante. Antes, convém compreender a caracterização desse governo como discricionário.

\footnotetext{
101 PEARSON, Drew. “A América Latina apoiará os EE. UU.?” In O Cruzeiro, Rio de Janeiro, 20 de novembro de 1948, n. 5, ano XXI.

102 PEARSON, Drew. A nação menos democrática da América Latina IN O Cruzeiro, Rio de Janeiro, 12 de março de 1949, n. 21, ano XXI.

${ }_{103}$ PEARSON, Drew. "Terror em Buenos Aires" In O Cruzeiro, Rio de Janeiro, 26/6/1948, p. 24

${ }^{104}$ PEARSON, Drew. "Perón tentou intervir no Paraguai" In O Cruzeiro, Rio de Janeiro, 10/1/1948, p. 16.

105 PERSON, Drew. "A Argentina pretende dominar a América” In O Cruzeiro, Rio de Janeiro, 29/05/1948, p. 64.

106 Idem.

107 PEARSON, Drew. "Londres prepara nova crise para os EE. UU." In O Cruzeiro, Rio de Janeiro, 20/9/1947, p. 16.

108 PEARSON, Drew "Receia-se nos EE.UU uma revolução no Brasil” IN O Cruzeiro, Rio de Janeiro, 19/3/1949, p. 96.
} 
Caudilho foi uma palavra empregada com bastante frequência para designar o presidente platino. Dessa forma, buscava-se relacioná-lo a uma suposta condição intrinsecamente autoritária da América Latina. Ainda em 1947, Samuel Wainer já usara essa expressão. Pouco tempo depois, Nasser, que constantemente acionava o termo para definir Getúlio Vargas, afirmou que Perón se apoiava nas massas valendo-se de raízes mais "afetivas que realmente lógicas":

Quanto aos métodos empregados [por Perón] - não diferem dos mesmos de todos os tempos dos autocratas de raça latina: a demagogia ruidosa, as demonstrações espetaculares para uma plebe nervosa e versátil, um verbalismo onde a confusão das ideias aparece na confusão das palavras. Toda essa 'mise-em-scene' [sic] tem por fundo um programa aparentemente definido, comporta, quase sempre, reviravoltas em momento oportuno. ${ }^{109}$

Essa imagem de Perón como mero caudilho remete a uma representação bem mais ampla da América Latina como lugar do caos, da violência política e do atraso. Difundida no Brasil desde os tempos do Império, tais imagens invocavam um Brasil supostamente vocacionado para a estabilidade e o progresso. ${ }^{110}$ Rafael Baitz, que analisou fotorreportagens sobre América Latina publicadas entre 1954 e 1964, constatou que tais representações ainda eram muito fortes no período. Nas fontes, os países latinoamericanos apareciam quase sempre como nações caóticas politicamente e inaptas para a democracia. Ao contrário do Brasil, mostrado como país de liberdade e grande progresso econômico, as imagens a respeito da América Latina enfatizavam a barbárie e a natureza exótica da região. Assim, tendiam a reforçar a ideia de um local fadado "à irracionalidade política, ao mandonismo de tiranos e ditadores sanguinários". ${ }^{111}$ Enfim, a região era apresentada como um lugar

[...] dominado por déspotas que exercem sem limites seus poderes sobre uma população analfabeta e passiva diante dos desmandos do estado. Quando não se apresentavam passivos [...], os latino-americanos eram retratados como portadores de uma personalidade exacerbada e mesmo irracional [...] Em todos esses casos, a América Latina era representada como local atrasado e impróprio para o desenvolvimento da democracia e, portanto, distante dos padrões da civilização ocidental. ${ }^{112}$

\footnotetext{
109 NASSER, David e MANZON, Jean. "Bancarrota Argentina" In O Cruzeiro, Rio de Janeiro, 12/2/1949, p. 12-20 e 24.

${ }^{110}$ PRADO, Maria Ligia C.."O Brasil e a distante América do Sul". Revista de Historia (USP), São Paulo, v. 145, 2001, p. 132.

${ }_{111}$ BAITZ, op. cit., p. 162.

${ }^{112}$ Ibidem, p. 116.
} 
Como se pode ver, o que Wainer e Nasser escreveram sobre o peronismo se enquadra muito bem nesse imaginário mais amplo e bem mais antigo a respeito da América Latina. No entanto, há certa especificidade nas representações a respeito do peronismo e esta passa principalmente por sua associação com o nazismo. Foi o que comentou Nasser: "O general Perón não é um simples caudilho para uso interno [...] o atual regime da Argentina é tipicamente militarista e tem como programa os mesmos sonhos expansionistas que definiram o regime hitlerista". ${ }^{113}$

A representação não era exatamente nova. Durante a guerra, antifascistas argentinos já associavam continuamente o regime do G.O.U. ao Terceiro Reich. Na campanha presidencial em 1945, a breve União Democrática, grupo de oposição à chapa encabeçada por Perón, teve como lema principal "Pela liberdade, contra o nazismo". 114

Muito mais do que o termo caudilho, outros adjetivos foram utilizados para descrever o governo platino, que foi chamado inúmeras vezes de "totalitário" e "hitlerista". Ao transcrever um discurso de tom imperialista, supostamente do "füeher da milonga""115, Nasser chamou a conferência de "Mein Kampf de Perón”. Além disso, “Gestapo" foi uma designação comum dada às forças policiais da Argentina, país que viveria “os seus dias mais negros e tristes, [...] as páginas mais cruéis de sua História, só comparável aos dias negros da Alemanha de Hitler e da Itália de Mussolini". ${ }^{116}$

Terror, medo e horror também foram palavras bastante utilizadas para definir o regime que vigiaria constantemente seus opositores. Esse poder "discricionário e policial"117 foi comparado a um "gigantesco polvo, cujos tentáculos abarcam os múltiplos setores de atividade". ${ }^{118}$ Curiosamente, a população argentina foi poupada das críticas e quase sempre recebeu adjetivos positivos, como "grande"119, "bravo" "amigo". ${ }^{121}$ Nessa chave interpretativa, nossos vizinhos não eram vistos como agentes políticos, mas como vítimas de um grande mal que impunha o silêncio absoluto, tal qual

${ }^{113}$ NASSER, David. "Marcado por Perón - o drama argentino" In O Cruzeiro, Rio de Janeiro, 30 de setembro de 1950, p. 26.

${ }_{114}^{114}$ CAPELATO, 2008, op. cit., p. 268.

115 OLIVEIRA, Franklin de. "Golpe e ameaça argentinos, dever brasileiro". Coluna Sete Dias In: $O$ Cruzeiro, Rio de Janeiro, 7 de abril de 1951, p. 7.

${ }^{116}$ GUIMARÃES, Josué e KEFFEL, Ed. ““'Complôs de mentira” - Os fugitivos de Perón (parte 2)”. In $O$ Cruzeiro, Rio de Janeiro, 8 de abril de 1950.

117 NASSER, David e MANZON, Jean. "Bancarrota Argentina" In O Cruzeiro, Rio de Janeiro, 12/2/1949, p.12-20 e 24.

${ }^{118}$ GUIMARÃES, Josué e KEFFEL, Ed. ““'Complôs de mentira” - Os fugitivos de Perón (parte 2)”. In $O$ Cruzeiro, Rio de Janeiro, 8 de abril de 1950, p. 44, 45, 46, 56, 74 e 68.

${ }^{119}$ NASSER, David. "Menina de 4 anos expulsa por Perón" In O Cruzeiro, Rio de Janeiro, 5/9/1953.

${ }^{120}$ NASSER, David. "Tango do Adeus" In O Cruzeiro, Rio de Janeiro, 15/10/1955, p. 12.

${ }^{121}$ NASSER, David. Perón insulta o Brasil: "Uma república de bêbedos" In O Cruzeiro, Rio de Janeiro, 7/10/1950, p. 15, 16, 17, 18 e 20. 
um "campo de concentração". ${ }^{122}$ Abaixo de uma foto do centro de Buenos Aires, por exemplo, pode-se ler como legenda:

Nesta cidade ninguém fala em política - nem mesmo a favor do peronismo. Há medo de confusões e intrigas. O chofer de táxi, o garção do bar, o caixeiro da loja, o engraxate da esquina - qualquer um pode servir como denunciante. A traição tem suas recompensas. ${ }^{123}$

Até mesmo termos relacionados ao mundo soviético foram aplicados para caracterizar o autoritarismo, tais como cortina de trigo ${ }^{124}$, cortina de ferro sulamericana $^{125}$ e, em referência a Evita, cortina de lingerie. ${ }^{126}$ Isso, porém, não foi tão comum. Ainda que Perón tivesse recebido a alcunha de "jacobino dos pampas" em uma das reportagens, predominou nessa fase de $O$ Cruzeiro a descrição dele como líder mais à direita do espectro político, que mantinha relações cordiais com os comunistas e a União Soviética por mera conveniência. Mais do que qualquer outra, a representação de Perón como "miniatura de Hitler"127 foi a que predominou no período.

As fontes mostram que essa representação estava fortemente relacionada ao passado recente. Como se sabe, ao contrário do Brasil, a Argentina não apoiou tão fortemente os Aliados e declarou guerra ao Eixo apenas poucos meses antes do final da Segunda Guerra. Além disso, o regime implantado por meio de um golpe em 1943 era apoiado por elementos ultranacionistas e germanófilos. Com o fim do conflito, o país foi continuamente acusado de receber os "mais conspícuos prófugas do Tribunal de Nuremberg" "128 e de ser abrigo para "o refugo das legiões nazistas e fascistas"129. Em uma reportagem, pode-se ler que "o melhor, ou o pior, do nazismo no mundo, se encontra atualmente na Argentina, colaborando abertamente com o seu governo". ${ }^{130}$ Sob

\footnotetext{
122 NASSER, David e KEFFEL, Ed. "Perón denunciado às Nações Unidas" In O Cruzeiro, Rio de Janeiro, 13/9/1952.

${ }^{123}$ GUIMARÃES, Josué e KEFFEL, Ed. “Aluga-se uma revolução. Os fugitivos de Perón - (parte V)”. $O$ Cruzeiro, Rio de Janeiro, 6/5/1950, p. 51 e 70.

${ }^{124}$ NASSER, David. "Argentina, república do medo - A mulher que fugiu do inferno" In O Cruzeiro, Rio de Janeiro, 10/10/1953.

${ }^{125}$ GUIMARÃES, Josué e KEFFEL, Ed. "Terror - a moderna arma da Argentina. Os fugitivos de Perón (parte IV)". O Cruzeiro, Rio de Janeiro, 29/4/1950, p. 51, 52 e 76.

${ }^{126}$ NASSER, David e WANDERLEY, Indalecio. "Perón balança, mas não cai” IN O Cruzeiro, Rio de Janeiro, 20 de setembro de 1951, p. 12, 13, 14, 15, 16, 17, 18, 19, 20 e 26.

${ }^{127}$ NASSER, David. “Tango do Adeus" In O Cruzeiro, Rio de Janeiro, 15/10/1955, p. 12.

${ }^{128}$ GUIMARÃES, Josué e KEFFEL, Ed. "“CComplôs de mentira” - Os fugitivos de Perón (parte 2)”. In $O$ Cruzeiro, Rio de Janeiro, 8 de abril de 1950, p. 44, 45, 46, 56, 74 e 68.

${ }^{129}$ NASSER, David. Espionagem de Perón no Brasil - Os agentes argentinos no Rio IN O Cruzeiro, Rio de Janeiro, 30/4/1949, n. 28, ano XXI, p. 43.

${ }^{130}$ GUIMARÃES, Josué e KEFFEL, Ed. "A tirania pelo medo - Os fugitivos de Perón (parte 1)". In $O$ Cruzeiro, Rio de Janeiro, $1^{\circ}$ de abril de 1950, p. 41, 42, 48 e 52.
} 
uma foto do Ministério da Guerra em Buenos Aires, a legenda informava que: "Os seus principais departamentos estão sob a direção técnica de agentes nazistas ali refugiados". ${ }^{131}$ Drew Pearson chegou a fornecer números, alegando que 8 mil alemães e italianos nazifascistas teriam chegado ao país em $1945 .{ }^{132}$ Em outra matéria, o jornalista Josué Guimarães citou 60 mil nazistas em solo platino, "desenvolvendo intenso trabalho de aliciamento político". 133

Ao longo de muitas décadas, a suposta colaboração com o regime alemão foi alvo de apaixonadas discussões políticas na Argentina, o que se refletiu em uma considerável historiografia a respeito. Em 1999, uma comissão criada pelo governo Menem e composta por representantes do governo, diplomatas e historiadores argentinos e estrangeiros concluiu que, entre milhares de imigrantes dos países do Eixo, entraram na Argentina, no mínimo, 180 criminosos de guerra. O número pode ser maior, mas essa foi a quantia que pôde ser comprovada pelos documentos levantados em diversos arquivos pela CEANA (Comisión para el Esclarecimiento de las Actividades del Nazismo en la Argentina). Em seu informe final, a comissão indicou que tal processo imigratório era de pleno conhecimento do governo Perón. ${ }^{134}$

Também sabiam desse tipo de imigração a Igreja Católica e a inteligência norteamericana e inglesa, que buscavam desnazificar a Alemanha e, ao mesmo tempo, impedir técnicos nazistas de imigrar para a nova potência, a União Soviética. No ano 2000, o então presidente Fernando de la Rúa pediu desculpas oficiais pelo fato de o país ter recebido criminosos nazistas.

De outro lado, como registra o sociólogo argentino José Paradiso, a pragmática política externa peronista buscou compensações que pudessem evitar a rejeição da comunidade judia. Ele escreveu:

\footnotetext{
A Argentina foi um dos países que recebeu maior quantidade de refugiados dessa origem, foi um dos primeiros a reconhecer o Estado de Israel [...] e houve numerosas personalidades judias no governo e entre os simpatizantes da força política que o sustentava. ${ }^{135}$
}

\footnotetext{
${ }^{131}$ GUIMARÃES, Josué e KEFFEL, Ed. "Terror - a moderna arma da Argentina. Os fugitivos de Perón (parte IV)”. O Cruzeiro, Rio de Janeiro, 29/4/1950, p. 51, 52 e 76.

132 PEARSON, Drew. "As catástrofes começam no verão” In O Cruzeiro, Rio de Janeiro, 27/8/49, p. 70

133 GUIMARÃES, Josué e KEFFEL, Ed. "Terror - a moderna arma da Argentina. Os fugitivos de Perón (parte IV)". O Cruzeiro, Rio de Janeiro, 29/4/1950, p. 51, 52 e 76.

134 O $\quad$ relatório final está disponível no endereço http://www.bnaibrith.org.ar/PDFs/CEANAINFORMEFINAL.pdf . Acesso em 15/09/2014

${ }^{135}$ PARADISO, José. "Vicisitudes de una política exterior independiente" In TORRE, Juan Carlos (org.). Nueva Historia Argentina. Tomo VIII. Los años peronistas (1943-1955), Buenos Aires, Ed. Sudamericana, 2002. p. 545 [tradução nossa]
} 
De acordo com Iuri Cavlak, ainda que o número de criminosos nazistas na Argentina tenha sido menor do que o ventilado, "a sensação de presença e continuidade das atividades nazistas no peronismo esteve calcada nos métodos de propaganda política, inspirados nos regimes autoritários europeus". ${ }^{136}$ De fato, o estudo de Maria Helena Capelato mostrou, por meio de inúmeros exemplos, que

[...] os organizadores das propagandas varguista e peronista, atentos observadores da política de propaganda nazifascista, procuraram adotar os métodos de controle dos meios de comunicação e de persuasão usados na Alemanha e na Itália, adaptando-as às realidades brasileira e argentina. ${ }^{137}$

Essa percepção já existia no período. Em 1951, por exemplo, o colunista Franklin de Oliveira foi bem explícito a denunciar que "a ditadura oclocrastra do General Perón emprega, na sua peçonhenta manobra, um grupo de trabalhadores que sua propaganda nazista obliterou nos paroxismos de um fanatismo selvagem". ${ }^{138}$

A associação com o nazismo se deu também pela ênfase na dura repressão aos políticos, estudantes universitários e jornais opositores. Poucos meses antes da eleição presidencial no Brasil, o jornalista gaúcho Josué Guimarães assinou uma série de cinco reportagens intitulada "Os fugitivos de Perón", na qual tratou das histórias individuais dos exilados que se encontravam em Montevidéu. Essas matérias contra o "ditador mais retardado do mundo"139 concentraram-se no que ocorria no país vizinho e não fizeram menção ao cenário político brasileiro.

Josué Guimarães descreveu o medo dos inimigos do regime, que não tinham "um minuto sequer de trégua" e eram "vigiados dia e noite, nas suas casas, nos clubes, nos escritórios e consultados, na rua e nos teatros e cinemas". A gendameria argentina foi novamente chamada de "Gestapo peronista". Em algumas reportagens, foram apresentados detalhes das terríveis sessões de tortura promovidos por ela.

Entre os entrevistados merece destaque especial Agustín Rodríguez Araya, deputado da União Cívica Radical, que perdera o mandato após fazer violento discurso contra desvios financeiros na administração justicialista. Como se verá, Araya foi o

\footnotetext{
${ }^{136}$ CAVLAK, Iuri. "Nazismo na América do Sul: A questão do peronismo". Boletim Tempo Presente (UFRJ), v. 8, 2013.

${ }^{137}$ CAPELATO, 2008, op. cit., p. 76-77.

${ }^{138}$ OLIVEIRA, Franklin. "Violência e ignomínia". Coluna Sete Dias In: O Cruzeiro, Rio de Janeiro, 17 de março de 1951, p. 7.

${ }_{139}$ GUIMARÃES, Josué e KEFFEL, Ed. "A tirania pelo medo - Os fugitivos de Perón (parte 1)”. In $O$ Cruzeiro, Rio de Janeiro, $1^{\circ}$ de abril de 1950.
} 
exilado antiperonista mais ativo na imprensa brasileira, tendo publicado inúmeros artigos, principalmente na Tribuna da Imprensa. Além dele, sobressaiu o também exdeputado radical Raúl Damonte Taborda, que chegou a ficar algum tempo exilado no Brasil, onde publicou um livro contra Perón, mas depois retornou ao Uruguai. ${ }^{140}$

Essa presença constante na imprensa brasileira de artigos escritos por antiperonistas exilados em Montevidéu indica a existência de uma curiosa rede de sociabilidade entre elementos da oposição dos dois países. Aparentemente, havia contatos frequentes, já que Nasser, Lacerda e outros foram até o Uruguai em mais de uma ocasião e escreveram reportagens a respeito. Assim, não é de estranhar as coincidências entre os discursos antiperonistas no Brasil e os dos exilados argentinos no Uruguai.

A propósito, o Uruguai recebeu, em várias ocasiões, elogios rasgados por sua democracia e por receber tantos proscritos oriundos do outro lado do rio da Prata. Nasser, por exemplo, definiu o país como "reduto de um povo livre, vizinho de um povo escravo". ${ }^{141}$ Em outras ocasiões, o "pequenino Uruguai" foi comparado a um "oásis"142 de liberdade e, até, a um "potro bravio", um país "malcriado, teimoso, basco, em defesa de uma boa causa". ${ }^{143}$

A repressão à imprensa, tema que será explorado mais profundamente adiante, foi abordada desde os primeiros anos do governo peronista. Na Argentina, os veículos de comunicação críticos ao governo sofreram duramente com restrições de papel, processos judiciais e outras formas de intimidação e intervenção. Nas rádios, por exemplo, havia a obrigatoriedade de transmissão diária dos discursos do casal presidencial em um boletim de trinta minutos. Além disso, o regime incorporou, direta ou indiretamente, 23 jornais e 19 estações de rádio. ${ }^{144}$ Essa situação dos homens de imprensa não escapou aos colegas de profissão brasileiros, como se pode ler:

Toda a imprensa de Buenos Aires que era contra Perón quando ele era candidato, hoje em dia apoia o seu governo. Quais são os meios usados pelo presidente da Argentina para conseguir essa unanimidade quase total? Em

\footnotetext{
140 TABORDA, Raul Damonte. O caso Perón: uma conspiração internacional. Porto Alegre: Globo, 1954.

141 NASSER, David e KEFFEL, Ed. "Perón denunciado às Nações Unidas" In O Cruzeiro, Rio de Janeiro, 13/9/1952.

${ }^{142}$ GUIMARÃES, Josué e KEFFEL, Ed. "A tirania pelo medo - Os fugitivos de Perón (parte 1)". In $O$ Cruzeiro, Rio de Janeiro, $1^{\circ}$ de abril de 1950.

143 NASSER, David e KEFFEL, Ed. "Pimenta nos olhos dos outros - O suplício das telefonistas" In $O$ Cruzeiro, Rio de Janeiro, 18/10/1952.

${ }^{144}$ CAPELATO, 2008, op. cit., p. 95.
} 
alguns casos, a intimidação reforçada pelas multas pesadas, justificando-as pela violação de decretos municipais ou leis federais. Outras vezes, o governo se limita ao fechamento puro e simples. Geralmente, isto se faz por intermédio do Banco Central, que pode cortar o abastecimento de papel e criar dificuldades econômicas sem solução. Outro meio é ainda a aquisição de jornais através de companhias ligadas ao Governo. ${ }^{145}$

De outro lado, as denúncias de corrupção foram menos enfocadas. Embora no insistente discurso moralista da UDN elas fossem bastante comuns, vistas em conjunto apareceram menos na abordagem sobre a experiência platina. Não faltaram, porém, algumas acusações. ${ }^{146}$ Outros "silêncios" também foram notados. Em O Cruzeiro, por exemplo, muito pouco se escreveu a respeito dos avanços no campo da legislação trabalhista, do voto feminino e da melhora na condição de vida dos trabalhadores mais pobres.

Por fim, vale destacar que a frequente associação entre peronismo e nazismo, tema deste subcapítulo, fazia parte de uma linha de pensamento maniqueísta, que enfatizava a luta entre o bem e o mal. Este seria representado justamente por Perón, um dos "diabólicos representantes do mal, que se apresentam como lobos com pele de carneiro e arrastam primeiro os incautos - e a canalha depois". ${ }^{147}$ Esse maniqueísmo é particularmente perceptível na lavra de David Nasser, que escreveu:

[Perón] tem um norte: a dominação, o domínio absoluto, físico e espiritual. Tem um pretexto falso: a defesa dos débeis contra os fortes. Tem mil meios: a demagogia, a mentira, os recursos do Estado, para descambar no medo, no terror, nos cárceres, até a vida de seus opositores, se é necessário. Ele faz a história, porém a história, por seu lado, criou-o. Não é mais que a reencarnação do espírito do mal, o qual, como a enfermidades da esfera biológica, cumprem seu destino maligno na história dos povos. ${ }^{148}$

Quando o líder argentino foi derrubado em 1955, aquele que outrora fora descrito como "potro selvagem dos pampas" foi chamado de "humilde jerico recolhido a uma residência paraguaia, a caminho de um melancólico pasto hibernal". Nasser afirmou também que Perón teria transformado a Argentina na "rede de esgotos da mais

\footnotetext{
145 NASSER, David e MANZON, Jean. "Bancarrota Argentina" In O Cruzeiro, Rio de Janeiro, $12 / 2 / 1949$.

${ }^{146}$ Uma delas alegava que pessoas ligadas a Evita e a seu irmão teriam gasto uma fortuna para comprar a "maior fábrica de alumínio do mundo" na Itália. Perón teria sido ludibriado, pois a empresa, verificou-se depois, não passava de "humilde oficina, com dez operários apenas, destinada exclusivamente ao fabrico de panelas, chaleiras e bules". Ver: NASSER, David "Lama das botas de Perón" In O Cruzeiro, Rio de Janeiro, 19/2/1949, p. 43 e 44.

147 NASSER, David e KEFFEL, Ed. "Perón denunciado às Nações Unidas" In O Cruzeiro, Rio de Janeiro, 13/9/1952.

148 Idem.
} 
sórdida e cínica, da mais atrevida e agressiva quadrilha de 'gangsters' políticos, desde Hitler". Para isso, Evita, a "Carmen portenha", teria desempenhado "com brilho e talento" o papel "de inspiradora dos bandidos que ocupavam o poder". Longe de uma análise política profunda, Perón foi novamente descrito como um tirano que fazia parte dos "diabólicos representantes do mal”. O jornalista concluí que pessoas como ele eram:

[...] enfermidades malignas, de curso natural, de desenvolvimento natural, para as quais só a prevenção conduz a resultados satisfatórios. Ditadores, tiranos, governos policiais, de emanações fascistas ou de pruridos comunistas são tentáculos de um polvo canceroso. Felizes os povos que, como iluminados cirurgiões, sabem advinha-los e extirpá-los antes que se transformem em metástases insolúveis. Felizes os povos que os veem quando ainda aparecerem sob a máscara do amor ao povo. ${ }^{149}$

Tais representações convergem para um Perón como encarnação do mal e transmissor de uma doença que estaria infectando a Argentina, o justicialismo. Como se pode perceber, trata-se de uma perspectiva que busca personificar em um único indivíduo a responsabilidade por toda uma complexa gama de mudanças coletivas que vinham ocorrendo na sociedade argentina. Essa visão maniqueísta que apresentava o peronismo como mal supremo, similar ao que ocorreu na Alemanha nazista, prevaleceu a partir de 1948.

\subsection{Um novo Rosas - a política externa peronista}

Se Perón seguia os passos de Hitler, seria natural pensar que também faria guerras para expandir seu domínio. Com base em tal perspectiva, sua política externa beligerante seria consequência de uma política interna totalitária. Esse desdobramento da argumentação antiperonista é bastante evidente nas fontes. David Nasser apresentou um controvertido discurso de 1943 atribuído ao líder platino. O documento, fartamente citado em diversos escritos antiperonistas, é descrito como "sensacional" pelo jornalista. Nele, há fartos elogios à Alemanha ("A luta de Hitler na paz e na guerra nos servirá de guia") e trechos com planos explícitos para dominar a região:

Temos já o Paraguai; teremos a Bolívia e o Chile. Com a Argentina, Paraguai, Bolívia e Chile fácil será apoderar-se do Uruguai. Imediatamente, as cinco nações unidas atrairão facilmente o Brasil, devido a sua forma de governo [Estado Novo]. Caindo o Brasil, o continente sul-americano será nosso. Nosso domínio será uma realidade, realidade grandiosa, sem

\footnotetext{
${ }^{149}$ NASSER, David. “Tango do Adeus” In O Cruzeiro, Rio de Janeiro, 15/10/1955, p. 12.
} 
precedentes, nascida do gênio político e do heró́smo do Exército Argentino. ${ }^{150}$

Considerado apócrifo desde essa época, esse discurso foi reiteradamente citado como prova das supostas intenções militaristas do governo argentino em diversos meios de comunicação brasileiros. Nasser, como outros, não informou a fonte do documento. A possibilidade de fraude tampouco foi aventada por esses meios de comunicação.

Segundo José Paradiso, o final da guerra trouxera facetas contraditórias à Argentina. De um lado, o país acumulara grande saldo comercial ao abastecer nações em conflito; de outro, havia ficado praticamente isolada da comunidade internacional. Por ter declarado guerra ao Eixo apenas em março de 1945 e ter se oposto continuamente aos interesses dos Estados Unidos, o governo argentino "não podia livrar-se facilmente do peso que suponha ser visto como herdeiro de um regime militar pró-fascista". 151

Para romper esse isolamento, a política externa argentina adotou uma postura bastante ativa e pragmática, que culminou, até o ano de 1950, na assinatura de mais de 120 acordos comerciais com diversas nações, muitas delas da América Sul. ${ }^{152}$ O Itamaraty, sob as diretrizes pan-americanistas de Dutra, refugou maior estreitamento com o vizinho. Via na sede de integração argentina um indício de que Perón buscava comandar a região e ressuscitar o Vice-Reinado do Prata, que outrora fora governado a partir de Buenos Aires. Compreende-se, assim, por que o Brasil "desenvolveu uma política de bloqueio a quase todos os tratados que a Argentina pleiteou no continente, aconselhando o aparato diplomático da maioria das nações sul-americanas a não aprofundarem tratados políticos e comerciais com essa nação" ${ }^{153}$

Parte dos estudos acadêmicos recentes coincide ao apontar que a política externa peronista não foi expansionista. Sua estratégia consistia, nas palavras de Moniz Bandeira, mais em "ganhar simpatia e respeito [do que] antagonizar ou agredir os países vizinhos". ${ }^{154}$ De acordo com José Paradiso, artigos escritos por Perón mostram que ele realmente acreditava na integração entre os países sul-americanos para garantir ganhos

\footnotetext{
150 NASSER, David e MANZON, Jean. "Bancarrota Argentina" In O Cruzeiro, Rio de Janeiro, 12/2/1949, p. 14.

${ }^{151}$ PARADISO, op. cit., p. 528-9 (tradução nossa).

${ }^{152}$ CAVLAK, op. cit., p. 24.

153 Ibidem, p. 99.

${ }^{154}$ BANDEIRA, op. cit., p. 242.
} 
econômicos mútuos e contrabalançar a influência dos Estados Unidos. Desse modo, suas ideias passariam longe do objetivo de reconstruir o Vice-Reinado do Prata. ${ }^{155}$

Como explicar então a representação constante do governo peronista como intrinsecamente imperialista nos discursos da imprensa liberal-conservadora? Em que os opositores ao regime se basearam para justificar e promover tal imagem? A resposta parece estar relacionada a, pelo menos, três aspectos: o investimento nas Forças Armadas promovido por Perón, a valorização da memória de Juan Manuel de Rosas por aliados do regime e a divulgação de propaganda peronista no Brasil por meio de consulados e da embaixada no Rio de Janeiro.

Principalmente em seu primeiro mandato, o presidente argentino aumentou consideravelmente os gastos com as Forças Armadas, uma de suas bases de apoio político. Buscava, dessa forma, cativar a caserna e diminuir a desvantagem de equipamentos em relação ao Brasil, que recebera apoio técnico dos norte-americanos durante a Segunda Guerra.

Esse aspecto parece ter colaborado para que a representação de uma Argentina beligerante fosse tão alardeado não apenas na imprensa, mas também na diplomacia e entre parlamentares brasileiros do período. O estudo de Iuri Cavlak mostrou que, até o final dos anos 1940, na documentação da embaixada brasileira em Buenos Aires "não foi outra a tônica [...] senão de alerta em relação ao crescimento econômico e militar da Argentina, seu 'fechamento' político em torno do pacto populista e sua intrínseca vontade de colonizar seus vizinhos". ${ }^{156}$ Os ofícios assinados pelos funcionários diplomáticos constantemente davam conta do fortalecimento da indústria local, que poderia, em caso de necessidade, voltar-se para a guerra. Nessa documentação, os argentinos foram retratados como um povo em plena "empolgação bélica" e, num contexto de forte desenvolvimento da economia platina, temia-se, inclusive, o desenvolvimento da bomba atômica.

Dentro do Itamaraty, a atuação de alguns embaixadores e de funcionários de carreira explicitamente contrários ao peronismo também pode ter colaborado para que críticas e suspeitas fossem, nas palavras de Cavlak, tantas e de tão forte convicção. ${ }^{157}$ Em um comunicado, o embaixador brasileiro Ciro de Freitas Valle afirmou que Perón

\footnotetext{
${ }^{155}$ PARADISO, op. cit., p. 566 (tradução nossa).

${ }^{156}$ CAVLAK, op. cit., p. 69

${ }^{157}$ Ibidem, p. 70.
} 
errava ao pagar altos salários a peões que "imaginam serem explorados" e que os trabalhadores argentinos recebiam "talvez mais do que necessitam" para viver. ${ }^{158}$

Críticas sobre o encaminhamento do regime para a guerra partiram com frequência da oposição existente dentro da própria Argentina. Nas páginas de $O$ Cruzeiro, por exemplo, Agustín Rodriguez Araya, deputado radical exilado no Uruguai, condenou "a desenfreada corrida armamentista da Argentina" promovida pelo governo peronista, que desejaria "arrastar o país para um abismo que na certa reduzirá a Argentina ao mesmo estado dos países que fizeram a guerra na Europa". 159

Aparentemente, críticas como essas chegaram aos poucos ao Brasil e acabaram adquirindo traços próprios. É o que mostra um relatório reservado produzido em dezembro de 1948 pelo então deputado federal Arnon de Mello (1911-1983), vinculado à UDN. ${ }^{160}$ Ele foi à Argentina, entrevistou diplomatas e políticos oposicionistas e passou a acusar o regime justicialista de preparar uma guerra contra o Brasil. Com palavras muito parecidas com as de Araya, sua argumentação tinha como mote a ideia de que Perón buscava reviver a atuação imperialista de Juan Manuel de Rosas (17931877). A partir de então, essa associação tornou-se cada vez mais constante nos discursos dos políticos udenistas brasileiros.

A propósito, Rosas é um personagem que há muito alimenta paixões na historiografia e no mundo político argentino. Entre 1829 e 1832 e entre 1835 e 1852, ele foi governador de Buenos Aires e liderou despoticamente a Confederação Argentina, forma política adotada naquele momento na região. ${ }^{161}$ Desde os escritos de Sarmiento, Alberdi e Mitre, exilados por conta das perseguições do regime rosista, parte da historiografia argentina tendeu a destacar seu extremo autoritarismo. Durante o período peronista, essa linha de pensamento foi, grosso modo, mantida. Muitos diários opositores buscaram associar o líder justicialista ao caudilhismo e à barbárie de Rosas. De acordo com o historiador argentino Marcelo Fonticelli, isso esteve presente de forma constante em periódicos argentinos de diversas tendências, tais como os liberais $L a$

\footnotetext{
${ }^{158}$ Ibidem, p. 118.

${ }^{159}$ GUIMARÃES, Josué e KEFFEL, Ed. "A tirania pelo medo - Os fugitivos de Perón (parte 1)". In $O$ Cruzeiro, Rio de Janeiro, $1^{\circ}$ de abril de 1950.

${ }^{160}$ MELLO, Arnon de. Relatório reservado sobre a situação político-militar da Argentina e suas relações com o Brasil, Rio de Janeiro, 1949, p. 7. Classificação CPDOC/RJ: 327(81:82)/M527r.

$161 \mathrm{Na}$ ausência de um pacto federativo constitucional, as províncias teoricamente dispunham de considerável independência, embora sua política externa fosse gerida de maneira centralizada. Na prática, porém, "o governo de Rosas exerceu [de maneira autoritária] um poder de fato sobre as províncias, em alguns aspectos aproximando-se de um poder nacional”. Ver: FERREIRA, Gabriela Nunes. O Rio da Prata e a consolidação do Estado imperial. São Paulo: Hucitec, 2006, p. 35.
} 
Prensa e La Nación, o socialista La Vanguardia e o comunista El Patriota. ${ }^{162}$ Ao analisar La Vanguardia, por exemplo, Claudio Panella notou que, para reforçar a representação do peronismo como regime fascista, eram comuns "as referências diretas e indiretas - a Hitler, Mussolini, Franco e, como antecedente vernáculo, a Juan Manuel de Rosas". 163

No Brasil, porém, a imagem de Rosas ganhou um sentido um pouco diferente do adotado comumente pela oposição argentina. Mais do que seu autoritarismo interno, destacou-se sobretudo sua política externa, tida como imperialista. Vale lembrar muito brevemente que os problemas do Brasil com Rosas se iniciaram em 1830, quando ele vetou a navegação dos rios da região por outros países, o que prejudicou os interesses de Brasil, França e Inglaterra. Além disso, não reconheceu a declaração de independência do Paraguai, gerando suspeitas de que pretendia anexar esse país. ${ }^{164}$ Rosas interveio ainda na guerra civil uruguaia (1838-1851), local de exílio de muitos de seus opositores. Tais atitudes levantaram o temor, principalmente no Brasil, de que Rosas tivesse um projeto de expansão que buscasse reconstruir o Vice-Reinado do Rio da Prata, a antiga colônia espanhola controlada a partir de Buenos Aires que se fragmentou em quatro países (Argentina, Paraguai, Uruguai e sul da Bolívia) durante o processo de independência. Por conta disso, a diplomacia brasileira buscou bloquear suas ações. Após a intervenção brasileira na guerra civil do Uruguai, tropas do país ajudaram Justo José Urquiza, governador da província de Entre Ríos, a derrubá-lo na batalha de Monte Caseros (1852). Esse episódio marcou a representação de Rosas como caudilho expansionista, imagem que ainda reverberava na vida política nacional um século depois, como mostra o relatório de Arnon de Mello.

Esse resgate negativo da figura de Rosas pelos udenistas não parece gratuito. Era de seu conhecimento a existência de intelectuais argentinos que glorificavam Rosas e defendiam o domínio platino da região. Arnon de Mello mencionou o fortalecimento do Instituto Juan Manuel de Rosas, antro dos intelectuais da direita nacionalista, e as

\footnotetext{
162 PANELLA, Claudio. La prensa de izquierda y el peronismo (1943-1949): socialistas y comunistas frente a Perón. La Plata, Universidad Nacional de La Plata, 2007, p. 92.

${ }^{163}$ Ibidem, p. 55.

${ }^{164}$ De acordo com Francisco Doratioto, embora o Paraguai tivesse se separado oficialmente do Vice Reino do Río da Prata em 1811, até o início da década de 1840, o país não tinha contatos oficiais com seus vizinhos. A proclamação formal de sua independência só ocorreu em 1842 e o Brasil foi o primeiro país a reconhecê-la (1844). As críticas do governo de Buenos Aires à atitude brasileira levantaram a suspeita de que os argentinos pretendiam retomar o controle do Paraguai. Ver: DORATIOTO, Francisco. Maldita guerra: nova história da Guerra do Paraguai. São Paulo: Companhia das Letras, 2002, p. 24 e 25
} 
palestras de Lúcio Manuel Moreno Quintana, professor universitário e ex-embaixador bastante influente, que estava a difundir a ideia da reconstrução do Vice-Reino do Prata para "recuperar o que nos pertence". ${ }^{165}$ Em seu retrato da Argentina justicialista, Arnon de Mello escreveu: “[...] nunca, como agora, se glorificou tanto a Rosas na Argentina [...] Todos os cultores de Rosas estão em postos-chave do governo e do Partido Peronista. O movimento apaixona o Exército". 166

Embora exagerada, a descrição possui algo de realidade. De acordo com José Luis Beired, havia desde os anos de 1920 intelectuais da direita nacionalista que defendiam o projeto da "Grande Argentina". Antiliberais, católicos e defensores da interferência militar no mundo político, apoiaram e receberam apoio da Alemanha nazista. ${ }^{167}$ De acordo com Beired, "embora não tivessem participado do golpe de 1943, [...] o consideravam como algo que também lhes pertencia". ${ }^{168}$ Tanto que muitos participaram do governo do GOU por meio de cargos importantes nas áreas cultural e educacional. Em uma ótica revisionista, esses intelectuais consideravam o rosismo o período áureo do país por ter preservado tradições do período colonial, como o catolicismo e o hispanismo. Nessa perspectiva, a partir da derrota em Monte Caseros (1852), a nação teria entrado em um ciclo de decadência ao adotar de forma sistemática o liberalismo político e econômico. A situação poderia ser solucionada, porém, com a ascensão de um "caudilho moderno", que retomasse antigos valores e restaurasse o território do Vice-Reinado do Rio da Prata. ${ }^{169}$ Malgrado esses intelectuais dispusessem de pouco capital político efetivo, eles buscaram reinterpretar o passado de modo a justificar a intervenção militar argentina em países latino-americanos.

Ciente da controvérsia que cercava a figura de Rosas, a propaganda oficial justicialista negou-se prudentemente a associá-lo a Perón. Preferiu promover a figura de Sarmiento, por exemplo. ${ }^{170}$ Obras públicas e ferrovias nacionalizadas foram batizadas

\footnotetext{
165 MELLO, op. cit., p. 31. Vale destacar que essas polêmicas conferências de Quintana também despertaram atenção na diplomacia brasileira, como atesta a correspondência levantada por Cavlak (CAVLAK, op. cit., p. 110.)

166 Ibidem, p. 33-34.

${ }^{167}$ BEIRED, Jose Luis Bendicho. “A 'Grande Argentina': um Sonho Nacionalista para a Construção de uma Potência na América Latina”. Revista Brasileira de História (Online), São Paulo, v. 21, n.42, 2001, p. 313.

${ }^{168}$ Ibidem, p. 314.

${ }^{169}$ Ibidem, p. 318.

${ }^{170}$ CAPELATO, 2008, op. cit., p. 258.
} 
com nomes de vários presidentes, mas evitou-se usar o nome de Rosas, tão alvejado pela oposição. ${ }^{171}$

A cautela do governo, porém, não impediu que a imagem de Rosas fosse constantemente utilizada pelos antiperonistas brasileiros. Aqui, no entanto, Rosas foi lido segundo uma chave diferente, na qual se explorava muito mais seu imperialismo do que seu autoritarismo em termos de política interna.

A esse respeito, o relatório de Arnon de Mello de 1948 parece dar algumas indicações preciosas. Inicialmente, ele admite que as denúncias de que o regime platino estava se tornando cada vez mais beligerante partia justamente dos socialistas argentinos:

\begin{abstract}
Como acentuou o Partido Socialista em seu manifesto de 28 de outubro último, assiste a Argentina à execução de um "plano geral para instalar o totalitarismo à crioula, à maneira rosista, ainda que filho putativo do pangermanismo hitleriano, do fascismo mussoliniano e do falangismo franquista". ${ }^{172}$
\end{abstract}

No entanto, seu texto envereda por um ponto de vista muito particular, próprio de alguém que está deste lado da fronteira. Os historiadores do país vizinho são acusados de estimular constantemente "o espírito de revanche, quando acentuam que o Vice-Reinado do Prata foi desfeito por nossa influência [...]”. ${ }^{173}$ Sua própria análise conjuntural dos rumos do fenômeno justicialista baseia-se na suposta existência de precedentes expansionistas no passado argentino. É o que indica a seguinte passagem:

[...] o maior apoio de que Perón dispõe para o bom sucesso dos seus planos, que tanto o fortalecem no poder, é o da História, onde se fixam e se aprofundam as suas raízes. Estudando o passado e a formação da Argentina, concluí-se que Perón é antes um produto do meio do que um acidente passageiro. ${ }^{174}$

Enfim, em pouco mais de setenta páginas Arnon de Mello retornou ao passado inúmeras vezes, comparando episódios e cenários para concluir: “Olhando a História de um século atrás, vemos que, como Perón repete Rosas, nós repetimos o Brasil de 1848 no desinteresse pela sorte dos nossos vizinhos e pela nossa própria sorte, diante da

\footnotetext{
171 Já a oposição argentina insistiu em comparar o peronismo ao rosismo. Curiosamente, opositores liberais civis comemoraram em Buenos Aires o centenário da batalha de Monte Caseros em 1952. Tratava-se de uma clara provocação ao regime justicialista (CAPELATO, 2008, op. cit., p. 269).

${ }^{172}$ MELLO, op.cit., p. 7.

${ }^{173}$ Ibidem, p. 50.

${ }^{174}$ Ibidem, p. 30.
} 
agressividade de Perón". ${ }^{175}$ Para o deputado, caberia ao Brasil naquele momento não tomar a iniciativa de ataque, mas adotar uma "atitude vigilante e enérgica" para evitar a agressão. $^{176}$

Esse relatório reservado de Arnon de Mello é especialmente importante, pois apenas dois meses após ficar pronto David Nasser assinou uma reportagem com conteúdo bastante semelhante. Ainda que não o cite diretamente, a similaridade de ideias parece indicar a proximidade entre líderes da UDN e veículos de comunicação como O Cruzeiro. Em "Bancarrota argentina", Nasser destacou o imperialismo do regime peronista inspirado em ideias nazistas. Com base em técnicas fascistas, Perón estaria transformando o país em um "grande circo" ao fomentar "o servilismo, a idolatria e o fanatismo entre as massas" ${ }^{177}$. Em outra reportagem, afirmou:

O governo argentino, que não exprime o pensamento do povo de sua terra, prepara-se para uma aventura bélica, construindo apressadamente fábricas de aviões e outras armas, estudando o preparo da bomba atômica e rasgando estradas estratégicas na fronteira do Brasil. Como se sabe que toda a válvula de escape de uma ditadura é a ação militar contra outra nação, o Brasil deve estar preparado. Somos partidários de uma política de fraternidade e de excelente vizinhança, mas é nosso dever advertir o povo, o Exército e o Governo do Brasil contra o excesso de boa-fé. Se a Argentina se arma, não será para combater na Coréia. Todas as nações têm o dever de se inquietarem e exigirem explicações quando os seus vizinhos se armam até os dentes. ${ }^{178}$

Em consonância com a representação de um líder expansionista, Perón foi apontado continuamente como o grande causador de distúrbios na região ao apoiar políticos e governos sul-americanos simpáticos à Argentina. Nas palavras de Arnon de Mello, "sabe-se que os movimentos armados, as conspirações e agitações verificadas na Bolívia, Peru, Venezuela, Chile, Paraguai e Uruguai foram de inspiração argentina". ${ }^{179}$ Nas páginas da imprensa liberal-conservadora, até mesmo o Bogotazo, série de protestos e enfrentamentos que se seguiram ao assassinato de Jorge Gaitán na Colômbia em 1948, foi apontado reiteradamente como obra de peronistas interessados em boicotar a IX Conferência Pan-americana, que estava reunida naqueles dias na cidade. ${ }^{180}$

\footnotetext{
175 Ibidem, p. 47.

${ }^{176}$ Tratava-se de negar o peronismo em bloco. Mello posicionou-se inclusive contra a intensificação do comércio entre os dois países, já que, em sua visão, isso poderia fortalecer economicamente a nação platina e financiar indiretamente sua corrida armamentista. Ibidem, p. 61.

177 NASSER, David e MANZON, Jean. "Bancarrota Argentina" In O Cruzeiro, Rio de Janeiro, 12/2/1949.

${ }^{178}$ NASSER, David. "Perón insulta o Brasil: "Uma república de bêbedos"” In O Cruzeiro, Rio de Janeiro, 7/10/1950.

${ }^{179}$ MELLO, op. cit., p. 42.

${ }^{180}$ Ver: PERSON, Drew. "Perón contra o continente” In O Cruzeiro, Rio de Janeiro, 15/05/1948, p. 34;
} 
No campo das relações econômicas, a abordagem não foi diferente. "Tratados comerciais nitidamente imperialistas" foi como Nasser definiu em 1950 os acertos feitos entre Buenos e La Paz. ${ }^{181}$ A dependência do Brasil em relação ao principal produto platino foi caracterizada por ele como "o jugo argentino do trigo". ${ }^{182}$ Em outras reportagens, destacou-se, ainda, a humilhação brasileira evidente no intenso contrabando de farinha de trigo na fronteira e ao "mendigar" o produto entre diversas nações produtoras. ${ }^{183}$ Drew Pearson também criticou repetidas vezes os preços de produtos primários praticados pelo governo peronista para uma Europa do pós-guerra em plena reconstrução. ${ }^{184}$

Além dos aspectos citados, parece ter contribuído bastante para essa imagem beligerante da Argentina a propaganda justicialista promovida a partir da embaixada e dos consulados platinos. Trata-se de um tema muito pouco abordado pela historiografia, mas abundante nas fontes. De acordo com Paradiso, tal propaganda era intencional e baseava-se numa concepção de Perón, de que, para além dos acordos com governos, era necessária uma ação orientada com os povos latino-americanos, "em cujo seio se procurava semear a ideia integracionista partindo da premissa de que eram [eles] os que realmente podiam impulsioná-la, impondo-se a conveniências setoriais ante as quais as autoridades costumavam sucumbir", ${ }^{185}$

No caso do Brasil, a divulgação dos ideais justicialistas foi condenada como interferência platina nos assuntos internos do país. Para os meios de comunicação liberais-conservadores brasileiros, a propaganda peronista seria uma forma de infiltração ideológica. As reportagens de $O$ Cruzeiro sobre o assunto estiveram relacionadas a pelo menos quatro aspectos dessa questão: caravanas de estudantes e

NASSER, David. "Espionagem de Perón no Brasil - Documento revelador". IN O Cruzeiro, Rio de Janeiro, 7/5/1949, p. 28 e 78.

${ }^{181}$ NASSER, David e MANZON, Jean. "A rebelde Bolívia - Sangue, estanho e dinamite” In O Cruzeiro, Rio de Janeiro, 18/3/1950.

${ }^{182}$ NASSER, David e SCLIAR, Salomão. "Pão nosso de cada dia - A vergonha do trigo" In O Cruzeiro, Rio de Janeiro, 29/05/1948.

${ }^{183}$ Idem

${ }^{184}$ Cf PEARSON, Drew . "Livro branco contra Trujillo" In O Cruzeiro, Rio de Janeiro, 21/2/1948, p. 34. Vale destacar que o sociólogo José Paradiso pintou um quadro um pouco mais complexo daquele momento. Para ele, "nas condições em que se encontrava a economia, impossibilitada de valer-se de saldos favoráveis bloqueados em Londres e afetada pelo deterioramento dos termos de comércio, era razoável que [o governo] procurasse obter os melhores preços por seus produtos agropecuários, algo que, a propósito, faziam outros exportadores. No entanto, não pode evitar que essa atitude fosse julgada criticamente e se tratasse como se autoridades argentinas procurassem se aproveitar de uma situação de carências mundiais exigindo preços exorbitantes para os produtos do país". PARADISO, op. cit., p. 530 (tradução nossa).

${ }^{185}$ PARADISO, op. cit., p. 570 (tradução nossa). 
trabalhadores a Buenos Aires, jornais supostamente financiados pelo regime, propaganda peronista no meio sindical e aproximação com políticos trabalhistas.

A respeito das caravanas, principalmente de universitários brasileiros, David Nasser afirmou que elas eram "recebidas de maneira estranhamente carinhosa" por Perón, que, além de financiar toda a viagem, encontrava-se pessoalmente com eles com bastante frequência. Nessas ocasiões, os alunos recebiam folhetos e livros sobre a doutrina justicialista, "camuflados de material de divulgação turística". Para ele, tais gentilezas faziam parte de um plano bem arquitetado. Explica Nasser:

\begin{abstract}
Existe, paralelamente, um movimento bem coordenado de propaganda, de formação de um exército de simpatizantes dentro das fronteiras do Brasil. Para a tomada de corações, em nada difere o plano de Perón do executado por Hitler antes da segunda guerra. Todas as caravanas brasileiras, sejam de estudantes ou de bancários, de oficiais de justiça ou de agricultores, passam a ser imediatamente consideradas hóspedes oficiais e recebem um tratamento especial. Os presentes cativam os visitantes e além dos souvenirs, acumulamse nos quartos de hotéis, roupas e objetos de uso pessoal. Os rapazes são levados a casas de ruidosa alegria, onde podem sentir a Buenos Aires amorosa e sensual, guardando da Argentina e especialmente de Perón, as mais agradáveis lembranças. ${ }^{186}$
\end{abstract}

Aparentemente, o assunto interessava a opinião pública nacional. Arnon de Mello citou-o em seu relatório. De acordo com ele, Buenos Aires recebera apenas em julho de 1948 cerca de seiscentos estudantes brasileiros, a maioria secundaristas, em viagem patrocinada. ${ }^{187}$ Grupos de escreventes da justiça e bancários também teriam assistido a palestras com Perón. Nas páginas de O Cruzeiro, Vera Pacheco Jordão destacou o assunto em uma crônica sobre a visita de professoras primárias à capital portenha. Lembrou a temerária interferência do regime no ensino superior argentino, que até aquele momento teria levado mais de mil e trezentos professores a serem demitidos ou se autoexonerado em protesto contra seu autoritarismo, chamado de "vírus indesejável". Escreveu a cronista:

Acabamos de sair do regime ditatorial que deixou profundas marcas em
nosso povo, sobretudo na mocidade que cresceu ignorando os moldes
democráticos. Somos ainda um povo em formação, sem consciência coletiva,
sem princípios cristalizados que possam resistir à sedução de enganadores
sucessos [sic]. Ao apreciar o progresso argentino, o alto nível de vida em
Buenos Aires, a excelente instalação das escolas, saberão os nossos jovens
distinguir entre aquilo que é construção secular do povo argentino e de

186 NASSER, David. Espionagem de Perón no Brasil - Documento revelador. IN O Cruzeiro, Rio de Janeiro, 7/5/1949, p. 28 e 78.

${ }^{187}$ MELLO, op. cit., p. 55. 
grandes estadistas, e a contribuição do governo peronista que se arroga todas as realizações? Mais ainda, saberão isolar o espírito e a letra [sic], discernindo a base falsa sob as aparências brilhantes, a deturpação do espírito escravizado, a negação da cultura avassalada pela política?

Só podemos deixar aqui esta advertência, para que abra os olhos daqueles que, demasiado prontos em admirar, queiram trazer de alheias terras sugestões aparentemente benfazejas mas contaminadas por um vírus indesejável. ${ }^{188}$

Em relação aos periódicos, Nasser apontou a existência de pelo menos dois jornais cariocas de baixa circulação supostamente subvencionados pelo governo platino. ${ }^{189}$ Embora não cite os títulos, sabe-se que um deles era $O$ Mundo, de propriedade do empresário Geraldo Rocha, tido como um dos "maiores amigos de Perón no Brasil". ${ }^{190}$ Em consonância com a tese da infiltração justicialista, os jornais e jornalistas favoráveis ao governo argentino foram considerados "ponta de lança" do peronismo no Brasil e chamados "lavais mulatos e caboclos"191 e "lavais indígenas"192, em uma referência ao político francês Pierre Laval (1883-1945). ${ }^{193}$ Sobre a atuação desses meios de comunicação, Nasser afirmou que estariam propositalmente promovendo a discórdia na vida política nacional para enfraquecer o país. Ele escreveu:

[...] Os peronistas estão fazendo no Brasil, contra as classes armadas, o parlamento, os homens públicos e os industriais, o mesmo, exatamente o mesmo, que fizeram os alemães na França; minando a confiança popular contra as forças vivas da nação, aquelas que poderiam fazer frente, de pronto, às ameaças externas. ${ }^{194}$

Além de jornalistas, outras pessoas foram apontadas como traidores, "brasileiros que venderam sua Pátria, que a trocaram pelo dinheiro de Perón". ${ }^{195}$ Apesar de algumas insinuações em torno do nome de Ademar de Barros, quem realmente foi atingido por

\footnotetext{
188 JORDÃO, Vera Pacheco. "Nuestra Argentina" In O Cruzeiro, Rio de Janeiro, 9/7/1949, p. 3.

189 NASSER, David. "Espionagem de Perón no Brasil - Os agentes argentinos no Rio" IN O Cruzeiro, Rio de Janeiro, 30/4/1949, n. 28, ano XXI. É interessante notar que em reportagem de 1950 Nasser anunciou para breve o surgimento de um terceiro jornal peronista no Rio de Janeiro. Este título também não foi localizado por nós. Ver: NASSER, David. "Perón insulta o Brasil: "Uma república de bêbedos""” In $O$ Cruzeiro, Rio de Janeiro, 7/10/1950.

190 NASSER, David e MANZON, Jean. "Bancarrota Argentina" In O Cruzeiro, Rio de Janeiro, 12/2/1949.

${ }^{191}$ NASSER, David. "Espionagem de Perón no Brasil - Documento revelador". In O Cruzeiro, Rio de Janeiro, 7/5/1949, p. 28 e 78.

192 NASSER, David. "Marcado por Perón - o drama argentino" In O Cruzeiro, Rio de Janeiro, 30 de setembro de 1950.

${ }^{193}$ Tido como símbolo de traição, Pierre Laval foi executado após condenação por alta traição e colaboração com os nazistas no período em que foi primeiro-ministro do governo de Vichy.

${ }^{194}$ NASSER, David. "Marcado por Perón - o drama argentino" In O Cruzeiro, Rio de Janeiro, 30 de setembro de 1950.

${ }^{195}$ NASSER, David. "Só a morte calará a minha voz" In O Cruzeiro, Rio de Janeiro, 23/4/1949, n. 27, ano XXI.
} 
essas acusações foi João Batista Lusardo, deputado federal pelo PSD, ex-embaixador na Argentina e notório defensor do peronismo. Ao denunciar seu suposto enriquecimento ilícito por meio de negócios na Argentina, Nasser questionou: "Qual o papel desse homem na trama sinistra que paira sobre a América do Sul? Quais são os compromissos de Lusardo para com o General Perón? Até onde? Por que? Para que estranhos fins?”. 196

Já o jornalista Arlindo Silva, em reportagem intitulada "Ponta de lança dos descamisados", acusou o serviço diplomático argentino de distribuir aos sindicatos de trabalhadores de São Paulo livretos laudatórios ao peronismo, publicados em língua portuguesa. Para comprovar a acusação, a matéria foi recheada com fotografias dos folhetos entregues aos sindicatos, alguns já com o carimbo das instituições que os receberam. De acordo com Arlindo Silva, a escolha da capital paulista por parte do governo peronista estaria relacionada à existência de grande número de operários industriais naquela cidade. O jornalista comentou que "a tática adotada por ele [Perón] era a mesma que nós brasileiros já tivemos a desgraça de conhecer, e que é o ludibrio das massas por meio de concessões que se afiguram como grandes conquistas das mesmas". ${ }^{197}$ Em uma legenda, a crítica ao varguismo apareceu de forma bem mais explícita: “Alguns [livretos] são escritos em castelhano, outros em português [...] e trazem expressões vagas, de sentido dúbio, lembrando os discursos do ex-ditador Vargas".

A propósito, quando questionado sobre a propaganda em outros países, Perón costumava afirmar que se o justicialismo ultrapassava as fronteiras isso não era culpa dos peronistas, pois as fronteiras não representam cercas para as ideias. ${ }^{198} \mathrm{Em}$ outra ocasião, ele admitiu o uso propaganda como arma de sua política externa e justificou-se ao afirmar que "não é possível empregar a resignação como única defesa aos ataques que se recebe". ${ }^{199}$ Aos políticos conservadores brasileiros, tudo isso parecia muito suspeito.

Desconfianças a respeito de ligações entre peronistas e membros do PTB também foram publicadas. Em 1949, Nasser escreveu: "Uma aliança secreta é entabolada entre Perón, Luis Carlos Prestes e Getúlio. Fala-se numa linha telefônica direta entre S. Borja e Buenos Aires. Dos Estados Unidos vem uma informação que

\footnotetext{
196 NASSER, David e MANZON, Jean. "Bancarrota Argentina" In O Cruzeiro, Rio de Janeiro, 12/2/1949.

${ }^{197}$ SILVA, Arlindo. "Ponta de lança dos descamisados" In O Cruzeiro, Rio de Janeiro, 31/1/1948.

${ }^{198}$ PARADISO, op. cit., p. 537-538.

${ }^{199}$ SAAVEDRA, Marisol; "Peronismo y antiperonismo en Chile y Brasil” In Todo es Historia, no 369 , abril de 1998, p. 10.
} 
anuncia a visita "confidencial" do Sr. Getúlio Vargas a Juan Perón, em plena cidade de Buenos Aires". 200

Como era de se esperar, essas denúncias se intensificaram à medida que se aproximavam as eleições presidenciais de 1950, com a participação de ex-presidente gaúcho. Não é de estranhar, portanto, que duas reportagens profundamente condenatórias ao justicialismo tenham sido publicadas justamente às vésperas do pleito. $\mathrm{Na}$ ocasião, Nasser comparou o peronismo a "um foco de moléstia infecciosa e maligna". ${ }^{201}$ Na conclusão, pode-se ler:

\begin{abstract}
O governo argentino prestigiou a campanha do Sr. Getúlio Vargas no Brasil. Como provas materiais está a mudança de atitude e de ponto de vista de um jornal peronista do Rio, que passou do ataque ao elogio ao ex-ditador brasileiro. Existem indícios de que Perón forneceu vinte mil contos ao PTB para a campanha sucessória. Isto significa nada mais, nada menos, que a Argentina, com a eleição de SEU candidato à presidência deste país, terá em sua órbita mais uma nação americana. ${ }^{202}$
\end{abstract}

Como se verá, a partir desse período uma nova representação a respeito de um conluio entre trabalhistas e peronistas tonou-se cada vez mais constante. A imagem de "Perón, o imperialista" passou a conviver com a de "Perón, o conspirador". Embora diferentes, ambas destacavam o risco da liberdade do Brasil e dos brasileiros, que poderiam ser submetidos à escravidão, tal qual estaria ocorrendo com os argentinos.

Ciente de que a oposição e a imprensa norte-americana lhe atribuíam intuitos beligerantes, Perón promoveu, a partir de 1947, uma intensa campanha pela paz em vários países. Esta se deu especialmente a partir da divulgação de uma série de artigos em que o líder argentino defendia que o justicialismo poderia ser uma opção diante do enfrentamento entre capitalismo e comunismo. Perón afirmava que o segundo era efeito do primeiro e que a Argentina havia superado a ambos por meio de uma terceira via pacifista, o justicialismo. Ainda que essa iniciativa tenha conseguido considerável alcance, nas palavras de José Paradiso, “ela não era suficiente para neutralizar os efeitos do preconceito antiargentino nem podia impedia que se interpretasse como parte de um propósito propagandístico menos interessado do que o que lhe atribuía seus

\footnotetext{
200 NASSER, David e MANZON, Jean. "Bancarrota Argentina" In O Cruzeiro, Rio de Janeiro, 12/2/1949.

${ }^{201}$ NASSER, David. "Marcado por Perón - o drama argentino" In O Cruzeiro, Rio de Janeiro, 30 de setembro de 1950 .

${ }^{202}$ NASSER, David. "Perón insulta o Brasil: "Uma república de bêbedos"” In O Cruzeiro, Rio de Janeiro, $7 / 10 / 1950$.
} 
inspiradores". ${ }^{203}$ Assim, apesar dos esforços de propaganda pacifista e de não ter realmente mobilizado tropas para nenhum conflito, a representação do regime peronista como intrinsecamente bélico permaneceu forte por muitos anos.

Para além da força dos Estados Unidos e das oposições nesse processo, menciona-se aqui a ideia de Paradiso ao alegar uma "dificuldade congênita do peronismo em fazer tudo bem". ${ }^{204}$ Em termos de política externa, o que se construía por um lado, era comprometido, muitas vezes, por outro flanco do justicialismo. Foi o que aconteceu, por exemplo, com a já citada atuação dos intelectuais da direita nacionalista ligados ao governo. Eles frequentemente dinamitavam possibilidades de aproximação com países vizinhos por meio de seus discursos belicosos.

Além disso, ao fazer uma intensa campanha de propaganda do peronismo, a Argentina acabava por passar a imagem de que, mais do que impulsionar a integração sul-americana, o país buscava conduzir o processo. Indiretamente, essa política de divulgação ajudou a fortalecer a representação de Perón como revivescência de Juan Manuel de Rosas, figura bastante negativa no imaginário político brasileiro. Essa é também a conclusão da historiadora argentina Marisol Saavedra. De acordo com ela, a difusão do justicialismo no exterior, exitosa em certo sentido, contribuiu por outro lado para "aumentar os receios e desconfianças que já existiam em boa parte dos chilenos e brasileiros". 205

Ao destacar esses aspectos, não se busca aqui culpabilizar e tampouco isentar a política externa peronista pela não realização da aproximação com o Brasil no período de 1946 a 1950. Como mostraram outros trabalhos, inúmeras outras variáveis importantes estiveram em jogo nesse momento, como a importante atuação do governo dos Estados Unidos e das agências de notícias norte-americanas. Tentou-se aqui compreender a construção por um grupo social específico da imagem da Argentina peronista como potencial inimiga do Brasil e do sistema democrático. Como se viu, os sustentáculos dessa representação foram edificados a partir de estratégias como a ênfase e, até, a hiperbolização de alguns aspectos reais do peronismo apontados como negativos pelos meios de comunicação em questão.

\footnotetext{
${ }^{203}$ PARADISO, op. cit., p. 537-538 (tradução nossa).

${ }^{204}$ Ibidem, p. 571 (tradução nossa).

205 SAAVEDRA, Marisol; "Peronismo y antiperonismo en Chile y Brasil” In Todo es Historia, no 369 , abril de 1998, p. 9. (tradução nossa)
} 
Não se trata, vejam bem, de um povo selvagem, semicivilizado, um agrupamento de bárbaros, uma nação de índios em choque. Juan Domingo Perón conseguiu, em poucos anos de governo, transformar a mais rica nação de após-guerra [...] numa nação sem trigo, sem carne, sem democracia e sem o mais leve e remoto vestígio de liberdade de pensamento e de palavra [...] esses atentados à dignidade humana foram se tornando cada vez mais intensos, até chegar o momento em que se decidiu fazer a denúncia à O.N.U., não apenas como [acusações] argentinas, mas como seres civilizados. É como um grito angustioso que desperte a todas as consciências honradas do mundo [...] A atenção dos membros da Organização das Nações Unidas é chamada para esse verdadeiro império da tara, dos baixos instintos desenfreados, da crueldade bestial, atingindo, nessa outra sorridente, feliz próspera e civilizada Argentina, os mais altos degraus na escola do horror.

David Nasser ${ }^{206}$

\section{Capítulo 2 A barbárie peronista (1950-1953)}

${ }^{206}$ NASSER, David e KEFFEL, Ed. "Perón denunciado às Nações Unidas" In O Cruzeiro, Rio de Janeiro, 13/9/1952. 


\title{
2.1 Carlos Lacerda e a Tribuna da Imprensa
}

\begin{abstract}
A imprensa brasileira é contrária ao nosso país. Apesar disso, acredito que é possível fazer um trabalho eficaz de aproximação, pelo menos com os seus mais competentes representantes. A exceção fica por conta, em forma radical e permanente, de dois setores perfeitamente identificados do jornalismo local: a cadeia dos Diários Associados (Assis Chateaubriand) e Tribuna da Imprensa (Carlos Lacerda).

A primeira, com projeções em todo o Brasil, tem uma forma de intimidação enorme. [...] A Tribuna da Imprensa, de Carlos Lacerda, é, em escala muito inferior, o outro expoente de animosidade contra o nosso governo. A importância de ambas as empresas sobre a política externa está no fato de que, por pressão ideológica, conseguem influenciar outros jornais a atacar assuntos argentinos, difundindo o espírito característico da oposição que logo transcende o resto das esferas governamentais. ${ }^{207}$
\end{abstract}

Esse trecho integra uma nota secreta produzida pela embaixada argentina no Rio de Janeiro semanas antes do suicídio de Getúlio Vargas. Tal perspectiva da diplomacia platina é corroborada pelas fontes impressas. Malgrado as diferenças substanciais em relação a $O$ Cruzeiro, um virulento antiperonismo também pode ser observado nas páginas do jornal de Carlos Lacerda (1914-1977), o vespertino Tribuna da Imprensa.

Filho de um deputado federal de tendências esquerdistas, o jornalista fluminense foi batizado Carlos Frederico Werneck de Lacerda, com os dois primeiros nomes em homenagem a Karl Marx e Friedrich Engels. ${ }^{208} \mathrm{Na}$ juventude, militou no Partido Comunista do Brasil (PCB) e integrou a Aliança Nacional Libertadora (ANL), o que o levou a ser preso em algumas ocasiões por participar de atividades tidas como subversivas. A partir de 1938, dedicou-se a atividades jornalísticas, especialmente em $O$ Jornal, matutino carioca que pertencia a Chateaubriand. No ano seguinte, veio o traumático rompimento com a esquerda, após a publicação de um artigo profundamente anticomunista encomendado pelo Departamento de Imprensa e Propaganda (DIP) e assinado por ele. Expulso do PCB e tido como traidor, Lacerda perdeu muitos de seus antigos amigos, o que ajuda a entender seu gradual deslocamento para o lado oposto do espectro político. ${ }^{209}$

Já filiado à UDN e conhecido no circuito jornalístico da capital, Lacerda passou a assinar, a partir de 1946, a coluna "Na Tribuna da Imprensa", publicada no diário Correio da Manhã. Dono de uma retórica envolvente e agressiva, Lacerda, que se tornara um ferrenho antigetulista e anticomunista, defendia enfaticamente a entrada do

\footnotetext{
${ }^{207}$ Nota secreta da Embaixada da Argentina no Rio de Janeiro no. 888/1954, de 27 de julho de 1954. Citado por ALMEIDA, 2005, op. cit., p.149-150.

${ }^{208}$ MENDONÇA, op.cit., p. 21.

${ }^{209}$ Ibidem, p. 51-61.
} 
capital internacional e o alinhamento geopolítico do Brasil aos Estados Unidos. É desse período sua conversão ao catolicismo e uma crescente popularidade, especialmente perante as classes alta e média, o que o levou a um breve mandato como vereador no Rio de Janeiro, em 1947. Após romper com Paulo Bittencourt, dono do diário carioca, Lacerda fundou seu próprio jornal conservando o título da coluna que o tornara famoso.

Tribuna da Imprensa teve seu primeiro número publicado em 27 de dezembro de 1949. Na versão de seu proprietário, o vespertino teria nascido de uma campanha popular organizada por seus amigos, que angariou acionistas desejosos de "dispor de um veículo de comunicação que fosse, acima de tudo, imparcial e dissesse a verdade". ${ }^{210}$ Embora Lacerda insistisse no caráter popular dos fundos levantados para criação do jornal, a historiadora Marina Gusmão de Mendonça demonstrou o contrário. Segundo a autora:

É muito mais provável que o surgimento da Tribuna da Imprensa tenha resultado na mobilização de grupos empresariais vinculados ao capital externo ante o nacionalismo que começava a tomar conta de setores do Exército e da própria burguesia industrial, e que conseguira paralisar a tramitação de um projeto governamental que garantiria participação de investimentos estrangeiros na exploração do petróleo.

O simples exame da relação dos maiores acionistas corrobora essa tese, bem como a constatação de que, entre os principais organizadores e, posteriormente, dirigentes da empresa, estavam figuras de proa do empresariado, com notórias vinculações externas, ou, ao menos, pessoas que com esses grupos mantinham estreitas ligações. ${ }^{211}$

O "jornal do Lacerda" "212 nunca atingiu grandes tiragens. No auge, em 1954, publicava 40 mil exemplares diários, enquanto outros vespertinos, como $O$ Globo e Última Hora, atingiam 110 e 92 mil exemplares, respectivamente. ${ }^{213}$ Samuel Wainer, seu inimigo na política e no mercado jornalístico, afirmou que "a circulação do jornal só subia nos momentos de crise ou quando Lacerda era preso". ${ }^{214}$ Ridicularizado como "lanterninha" da imprensa, Lacerda reagiu e incorporou a lanterna como marca do periódico a partir de 1953. Justificou fazendo referência à lamparina do filósofo grego Diógenes, "símbolo da eterna procura por um homem honesto". ${ }^{215}$

\footnotetext{
${ }^{210}$ Ibidem, p. 100.

${ }^{211}$ Ibidem, p. 101-102.

${ }^{212}$ Esse personalismo foi corroborado por depoimentos do período. Aluísio Alves, então redator-chefe do periódico relatou certa vez que uma das dificuldades do cotidiano era o "método de Lacerda, que participava de tudo, escrevia do seu artigo à pequenas notas, acompanhava todas as seções do jornal, orientava, reclamava, modificava, numa velocidade de trabalho difícil de acompanhar'(Apud RIBEIRO, 2007, op. cit., p. 148).

${ }^{213}$ RIBEIRO, op. cit., p. 60.

${ }^{214}$ Ibidem, p. 145.

${ }^{215}$ MENDONÇA, op. cit., p. 131.
} 


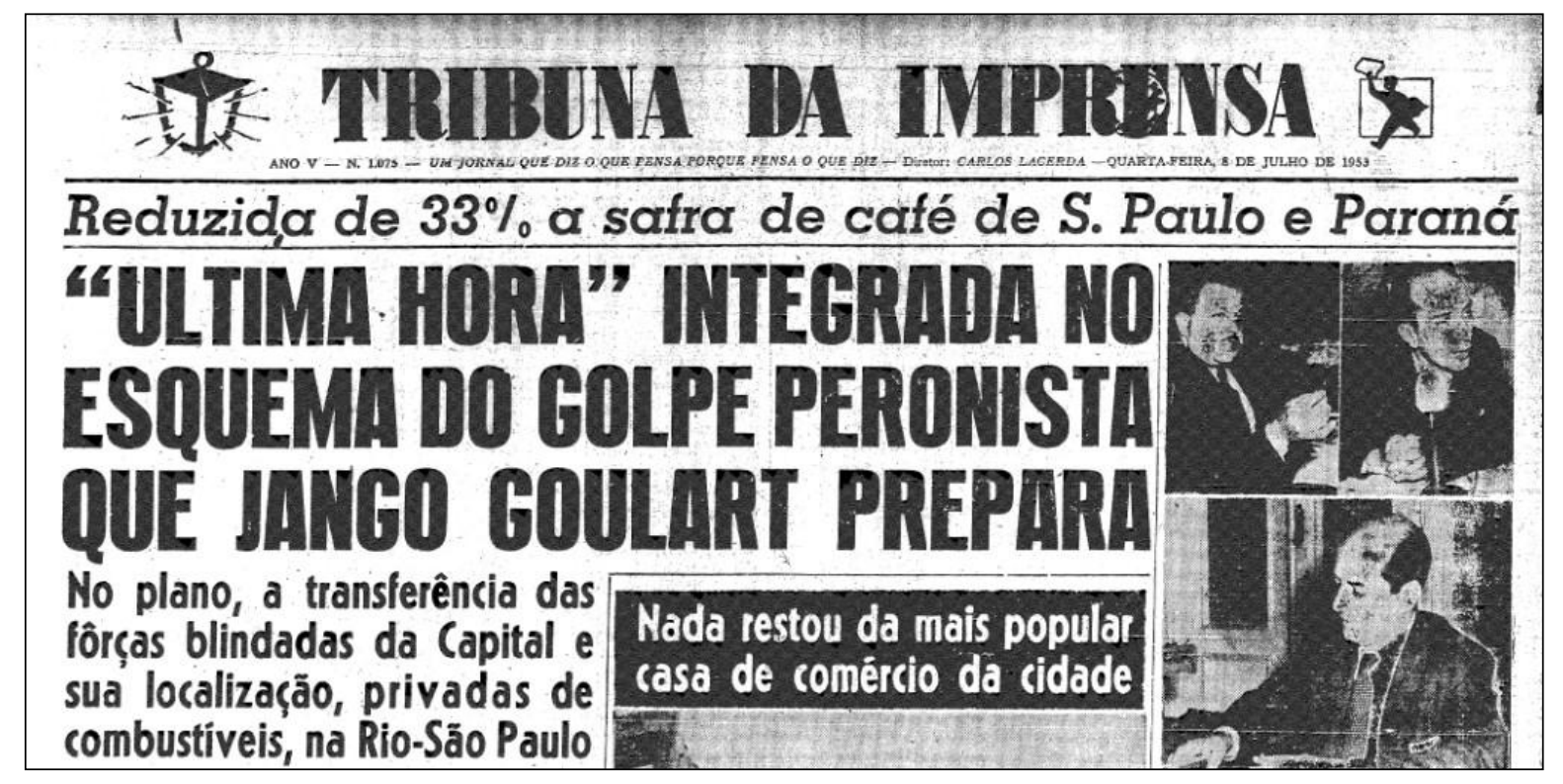

Figura 1 - Capa da edição de 8 de julho de 1953 com denúncias de suposto um plano golpista dos trabalhistas. Ao lado do título do jornal, a lanterna, símbolo do periódico.

Para a pesquisadora Ana Paula Ribeiro Goulart, a Tribuna da Imprensa ilustra bem as contradições da imprensa naquela década de 1950, pois estava dividida entre modernização e arcaísmo, entre informar e opinar. De um lado, seu estilo agressivo a aproximava "da antiga tradição do jornalismo do Império e da República Velha, dos diários polêmicos e combativos, marcados por um tom panfletário, instrumentos a serviço dos seus donos". Isso fica evidente, por exemplo, no seu lema sempre destacado abaixo do título na primeira página: "Um jornal que diz o que pensa porque pensa o que diz". Como empresa, também lembrava os velhos diários, pois contava com estrutura administrativa precária, passando por constantes crises financeiras. Ainda assim, a redação era composta por uma equipe de jornalistas e fotógrafos dinâmicos, que se pautavam cada vez mais pelos padrões do jornalismo norte-americano e que, nas palavras da autora, ajudaram a "modernizar" o jornalismo carioca. ${ }^{216}$

Apesar da tiragem baixa em comparação com outros órgãos da grande imprensa, a Tribuna da Imprensa era influente e incomodava os adversários. Na atuação de Lacerda, em especial, salta aos olhos a extrema violência discursiva contra os opositores, não raro recorrendo à calúnia pura e simples. Colocando-se como puritano

\footnotetext{
${ }^{216}$ RIBEIRO, op. cit., p. 143-153.
} 
defensor do povo, o jornalista descarregava com frequência sua metralhadora de denúncias que, em alguns casos, se baseavam em meras suspeitas ou indícios frágeis.

Dentre muitos casos de difamação, citam-se alguns que foram atingidos pela sua pena mordaz. O embaixador brasileiro em Buenos Aires João Batista Lusardo foi chamado de "nouveau riche devasosso e boçal" 217 e "centauro dos pampas, metade cavalo, a outra também"218. João Goulart recebeu, entre outros adjetivos, o de "moleque"219 "primário"220 e "figura ratona",221. O petebista gaúcho Irís Valls foi definido como "primário, ignorante, com certa esperteza de fronteiriço imprudente e impune, contrabandista nas horas vagas"222. Lutero Vargas seria o "filho rico e degenerado do Pai dos Pobres"223. Já o jornalista argentino Rizzo Barata foi classificado como "vagabundo sensacionalista" 224 . Ao criticar o clientelismo envolvendo políticos trabalhistas, definiu-os certa vez como um "ajuntamento de sardinhas que viaja nas costas do cetáceo de São Borja" [Getúlio Vargas]. ${ }^{225}$

Ao analisar os escritos de Lacerda, Marina Gusmão de Mendonça apontou sua constante tentativa de automitificação ao "construir a imagem de homem providencial, a do herói encarregado de salvar a pátria ameaçada". ${ }^{226}$ Tal sentimento parece ter sido continuamente reforçado pelos seguidos atentados que ele sofreu em consequência de sua atuação jornalística.

Essa autoimagem se coadunava com a insistente denúncia maniqueísta de que o povo estava sendo continuamente explorado por vilões corruptos. ${ }^{227}$ Segundo Lacerda, entre os inimigos que personificavam o mal a ser combatido estariam, a variar conforme o contexto, os trabalhistas (ou "gregórios", termo utilizado após a crise de agosto de

\footnotetext{
${ }^{217}$ LACERDA, Carlos. "Terror branco na Argentina”. Tribuna da Imprensa, Rio de Janeiro, 13/10/1951, p. 4.

${ }^{218}$ FRIAS FILHO, Otavio. "O Tribuno da Imprensa” In Piauí, Rio de Janeiro, no. 91, ano 8, abril de 2014, p. 30-38.

${ }^{219}$ LACERDA, Carlos. “Análise de um falso testemunho" In Tribuna da Imprensa, Rio de Janeiro, 6 de abril de 1954, p. 4.

${ }^{220}$ LACERDA, Carlos. Apaziguamento e legalismo de Chambelain a Sobral Pinto In Tribuna da Imprensa, Rio de Janeiro, 1/9/1955, p. 4.

${ }^{221}$ LACERDA, Carlos. "Aleluia argentina e paixão brasileira". Tribuna da Imprensa, Rio de Janeiro, 20/9/1955, p. 4.

${ }^{222}$ LACERDA, Carlos. "Fala Iris Falls, o peronista". Tribuna da Imprensa, Rio de Janeiro, 24-25/9/1955, p. 4.

${ }^{223}$ DELGADO, Marcio de Paiva. O "golpismo democrático". Carlos Lacerda e o jornal Tribuna da Imprensa na quebra da legalidade (1949-1964). Dissertação de Mestrado, Universidade Federal de Juiz de Fora (UFJF), 2006, p. 68.

${ }^{224}$ LACERDA, Carlos. "Tom Wallace, cidadão das Américas". Tribuna da Imprensa, Rio de Janeiro, 11/10/1951, p. 4.

${ }^{225}$ Apud DELGADO, op. cit., p. 10.

${ }^{226}$ MENDONÇA, op. cit., p. 12.

${ }^{227}$ Idem.
} 
1954 para definir o adeptos do varguismo), os peronistas e, principalmente, os comunistas, adversários bem conhecidos e eternos culpados pelos males que ameaçavam o país. A salvação dos valores tradicionais, segundo Lacerda, passaria pela organização e atuação de homens racionalmente superiores, paladinos da moralidade, pessoas com abnegada atuação, capazes de se manterem impolutos em nome do amor à pátria.

Essa retórica, que encontrava em Lacerda um de seus principais expoentes, integrava, de modo geral, o discurso da UDN. Criada nos meses finais do Estado Novo como um partido que bradava pela democracia, ela congregou, inicialmente, líderes com ideologias diversas, quando não antagônicas. Posteriormente, o desenrolar dos anos e das contendas eleitorais conferiu à agremiação um viés cada vez mais moralista e elitista, que repercutia especialmente bem entre parte das classes média e alta.

Para Maria Victoria de Mesquita Benevides, a identidade da agremiação se baseava, entre outras coisas, na "autoestima, reforçada pela crença na 'qualidade superior' de seus dirigentes". ${ }^{228}$ A autoimagem da excelência de seus quadros levou o partido a se colocar com frequência como um "pedaço de chão limpo", decente e digno em relação aos demais. ${ }^{229}$ Essa ideia de "partido incorruptível" era reforçada pela atuação parlamentar centrada nas constantes denúncias de desvios administrativos, de subversão da ordem provocada pelas políticas trabalhistas e da suposta infiltração comunista na sociedade. ${ }^{230}$ Não sem razão, o símbolo da UDN era a tocha olímpica com uma labareda, abaixo da qual constava o lema paranoico: "o preço da liberdade é a eterna vigilância". 231

O "temor onipresente à desordem", à anarquia que supostamente adviria com a "ascensão das massas ignorantes", emana de muitos discursos udenistas que identificavam as reivindicação sociais de comunistas e getulistas como agitações que ameaçavam o status quo.

As sucessivas derrotas nas eleições presidenciais de 1945, 1950 e 1955 reforçaram em muitos de seus membros a ideia de que era necessária uma "democracia tutelada", pois “o povo não sabe votar". Ou seja, não estaria preparado para usufruir a liberdade. Essa noção justificava os constantes apelos à intervenção militar contra um sistema político considerado "ilegítimo porque tolera (e até estimula) manifestações de

\footnotetext{
${ }^{228}$ BENEVIDES, op. cit., p. 224.

${ }^{229}$ Ibidem, p. 212.

${ }^{230}$ Ibidem, p. 172.

${ }^{231}$ Ibidem, p. 268.
} 
grupos sociais incompatíveis com a ordem desejada". ${ }^{232}$ Em consequência desse raciocínio, defendia-se que "o golpe é legítimo porque quer destruir um sistema ilegítimo"233 ou, nas palavras de Carlos Lacerda, de que seria necessário "defender o golpe para evitar o golpe por via eleitoral". ${ }^{234}$

Embora alguns de seus membros apoiassem ideias autoritárias, a UDN não pode ser considerada um partido de inspiração fascista. A agremiação enfatizava a importância da liberdade e da democracia, ainda que controlada e restrita. Nesse sentido, mesmo udenistas abertamente golpistas, como Lacerda, defendiam regimes autoritários apenas transitórios, capazes de limpar o terreno para a construção de uma suposta "democracia verdadeira", sem "agitadores" e "subversivos". Ou seja, advogavam uma espécie de "ditadura educativa". 235

É importante destacar também que as ideias de Lacerda expressas em seu jornal não representavam a UDN em sua totalidade. Avesso à disciplina partidária, o jornalista tinha atuação bastante personalista e chegou a criticar abertamente alguns colegas correligionários, especialmente aqueles que se mostraram dispostos a colaborar com os governos Vargas e Kubitschek. Isso gerava constantes atritos com a cúpula do partido. ${ }^{236}$ Em depoimento, o udenista Juracy Magalhães (1905-2001) elogiou “o 'tribuno admirável, inteligente, majestoso', que 'fascinava plateias com sua voz de sereia', mas que 'no dia a dia da convivência partidária comportava-se como um macaco em loja de louças". ${ }^{237}$ O próprio Lacerda admitiu em entrevista certa desvinculação entre seu diário e o partido:

\footnotetext{
Eu queria evitar muito que a Tribuna fosse um órgão da UDN, até porque isso era impossível; a UDN não podia ter um órgão - a UDN era uma maçaroca de tendências, as mais diversas, impossíveis de exprimir num só jornal. Sobretudo porque esse jornal exprimia muito mais as minhas tendências do que as tendências da UDN. Quer dizer, sempre me senti na UDN - e com isso não estou renegando os excelentes companheiros que tive lá, nem renegando a própria UDN como partido - mas sempre me senti meio como uma excrescência na UDN, mesmo porque tenho muito pouca vocação para política como exercício assim de habilidades e de astúcias. Acho que se perde muito tempo com a política, no sentido de meio, e não no sentido de fim, e a política como meio me interessa muito pouco, o que me interessa é o fim. E era dificílimo e revelou-se ser impossível fazer um jornal partidário. ${ }^{238}$
}

\footnotetext{
${ }^{232}$ Ibidem, p. 263.

${ }^{233}$ Idem

${ }^{234}$ Ibidem, p. 254.

${ }^{235}$ Ibidem, p. 255.

${ }^{236}$ Ibidem, p. 233.

237 Apud MENDONÇA, op. cit., p. 24-25.

${ }^{238}$ LACERDA, 1978, op. cit., p. 109-110.
} 
Certo é que, mesmo sem exercer mandato político no período entre 1951 e 1954, Lacerda transformou-se, aos poucos, em um dos principais líderes da oposição radical ao governo Vargas. Dono de uma retórica exuberante e ferina, ele soube capitalizar o espaço franqueado por Roberto Marinho em sua rádio e por Chateaubriand na TV Tupi. Sua atuação jornalística alimentava e era alimentada pelas denúncias constantes e implacáveis de uma ala da UDN, que ficou conhecida como "Banda de Música". Composto por homens públicos como Adauto Lúcio Cardoso, Afonso Arinos, Aliomar Baleeiro e Bilac Pinto, entre outros, o grupo fazia diariamente discursos inflamados e virulentos contra o governo. De acordo com o udenista João Agripino, o objetivo deles, que se postavam na primeira fila do plenário, era deliberadamente "fazer barulho, criar confusão, perturbar, obstruir e tirar o orador de sua fleuma". 239

A crescente força política de Lacerda levou ao surgimento de uma corrente personalista, o lacerdismo. Meses após o suicídio de Vargas, sua eleição para deputado federal com a maior votação do Rio de Janeiro mostrou que a polarização com o político gaúcho lhe rendera um eleitorado fiel. Em 1960, ele venceu as eleições para governador da Guanabara. De acordo com o historiador Márcio de Paiva Delgado, realizou um governo contraditoriamente marcado por grandes obras e muitos gastos públicos. ${ }^{240}$ Como era de se esperar, Lacerda apoiou deliberadamente o golpe militar de 1964. Ele já havia sido indicado candidato à presidência da República pela UDN para as eleições seguintes. ${ }^{241} \mathrm{O}$ pleito, como se sabe, nunca se realizou, já que a "ditadura temporária e pedagógica", defendida por ele com outros termos seguiu rumos diferentes.

Em um estudo de 1965, o sociólogo Gláucio Ary Dillon Soares concluiu que o lacerdismo não foi um fenômeno personalista alheio a ideologias. Demonstrou que as ideias do jornalista fluminense tinham penetração bem maior entre elementos das classes privilegiadas contrários ao intervencionismo do Estado e favoráveis ao capital estrangeiro. Dessa forma, ao contrário do que muitos acreditavam, sua propalada influência carismática tinha limites sociais bem definidos. ${ }^{242}$ Seu discurso violento e moralista encontrava repercussão especialmente entre as mulheres de classe média,

\footnotetext{
239 Apud BENEVIDES, op. cit., p. 84.

${ }^{240}$ DELGADO, op. cit., p. 127-128.

${ }^{241}$ BENEVIDES, op. cit., p. 130-131.

${ }^{242}$ SOARES, Gláucio Ary Dillon. "As bases ideológicas do lacerdismo" In Revista Civilização Brasileira, ano I, No. 4, Rio de Janeiro, setembro, 1965, p. 49-70.
} 
chamadas pejorativamente pelos adversários de "mal-amadas". Esclarece Marly Silva da Motta:

\begin{abstract}
A imagem viril e vibrante de Lacerda, associada a uma oratória apaixonada, tinha um alvo preferencial: o eleitorado feminino, cujo voto não era então obrigatório. Nesse sentido, a Tribuna e o próprio Lacerda passaram a desenvolver uma intensa campanha de alistamento desse eleitorado, tradicionalmente a elas dedicados: enfermeira, mãe, professora, esposa. ${ }^{243}$
\end{abstract}

Lacerda circulava bem entre grandes empresários da comunicação. Foi amigo pessoal da família Mesquita, proprietária do jornal O Estado de S. Paulo. ${ }^{244}$ Não era incomum encontrar nas páginas da Tribuna da Imprensa editorais que tinham sido veiculados nos dias anteriores no jornal paulistano. Em 1953, durante a CPI que investigou os empréstimos do Banco do Brasil ao jornal varguista Última Hora, ele recebeu apoio de Roberto Marinho e de Assis Chateaubriand, tendo amplo acesso a suas rádios, e no segundo caso, à televisão, para atacar Samuel Wainer e o governo. De acordo com Fernando Morais, nas manifestações após o suicídio de Vargas "faixas e palavras de ordem de passeatas de sindicalistas e estudantes pediam "morte a Lacerda e Chateaubriand" pelas ruas das capitais". ${ }^{245}$

No entanto, Lacerda cultivou desavenças até mesmo com seus aliados mais próximos. Em 1965, denunciou as relações da recém-criada TV Globo com o grupo empresarial norte-americano Time-Life, ferindo uma lei que proibia a participação do capital estrangeiro em empresas de comunicação brasileiras. Sua relação com Assis Chateaubriand também foi conflituosa. O mesmo pode-se dizer do seu convívio com o mais conhecido repórter dos Diários Associados, David Nasser. Em um artigo de dezembro de 1960, este fustigou:

\footnotetext{
Querido leitor, se for o caso de arranjar um noivo para sua filha, Carlos Lacerda não seria bom. Mas, para governador, ele é excelente. Ele não estima ninguém. Nem a ele mesmo. É um ser instintivamente totalitário, no melhor estilo. Não podendo destruir a democracia nos seus antigos arroubos comunistas, tornou-se um paladino da democracia, transformando-a, em sua amante. Trata-se de uma figura trágica [...] Escravo de mórbida natureza, nunca teve um amigo; mas este traço o fará bom administrador de uma cidade que ele sempre defendeu com tanto ardor. Como amigo, Lacerda é horrível; como companheiro de partido político, deve ser desagradável lidar com ele. ${ }^{246}$
}

\footnotetext{
${ }^{243}$ Apud DELGADO, op.cit., p. 66.

${ }^{244}$ CAPELATO, Maria Helena Rolim e PRADO, Maria Lígia. O Bravo Matutino: imprensa e ideologia: o jornal O Estado de S. Paulo. São Paulo: Alfa-Omega, 1980.

${ }^{245}$ MORAIS, op. cit., p. 558.

${ }^{246}$ Apud DELGADO, op.cit., p. 53.
} 
Apesar dessas palavras duras, Lacerda e Nasser se reconciliaram anos depois. Nasser referiu-se a ele como "meu amigo Carlos Lacerda"247 e chegou a defender sua indicação como imortal para a Academia Brasileira de Letras. ${ }^{248}$ Em entrevista de 1977, Nasser apontou Lacerda, o "terrível capeta de Vassouras"249, como um dos cinco grandes homens de sua época. ${ }^{250}$

Em relação especificamente ao antiperonismo, Lacerda e seu jornal tiveram uma atuação um pouco diferente de $O$ Cruzeiro. Talvez por ser um meio de comunicação personalista, no qual a interferência do dono fazia-se muito mais presente, havia em seu noticiário uma diversidade de representações consideravelmente menor. Como se verá, Lacerda elegeu algumas imagens negativas para se referir ao governo argentino e buscou "martelá-las" exaustivamente, especialmente em seus prolixos editoriais.

Também evidente é que, muito mais do que na revista de Chateaubriand, as más notícias do cenário platino eram diretamente utilizadas para atacar o governo Vargas, já que o jornalista via "o movimento marmiteiro como da mesma família dos descamisados". ${ }^{251}$ No caso específico de Lacerda, é muito perceptível que a grande hostilidade em relação à Casa Rosada tinha como alvo final o Palácio do Catete. A violência implacável de suas provocações ficou registrada nos ofícios da embaixada argentina na capital brasileira:

\footnotetext{
[Lacerda] aproveita qualquer oportunidade para fazer virulentos ataques contra o país e o governo. Recebe colaborações de exilados argentinos. Costuma publicar calúnias, injúrias e mentiras contra nossas autoridades públicas. O jornal está a serviço das ambições políticas de seu diretor, que deseja destacar-se mediante campanhas de moralização do ambiente brasileiro e de ataque à República Argentina. ${ }^{252}$
}

As caricaturas ou charges também foram parte importante do discurso político de jornais como Tribuna da Imprensa. Através de linguagem artística peculiar, elas possivelmente alcançaram grande repercussão junto ao público ao zombar homens públicos, mostrando-os não como seres sacralizados, mas permeados por defeitos.

\footnotetext{
${ }^{247}$ CARVALHO, op.cit., p. 488.

${ }^{248}$ Ibidem, p. 497.

249 NASSER, David. "Samuel Wainer, a aventura mais cara do Brasil" In O Cruzeiro, Rio de Janeiro, $1 / 8 / 1953$.

${ }^{250}$ Ibidem, p. 541-542.

${ }^{251}$ DULLES, John W. Foster.Carlos Lacerda: a vida de um lutador (1914-1960). Rio de Janeiro, Nova Fronteira, 1992, v.1, p. 94.

${ }^{252}$ ALMEIDA, 2005, op. cit., p. 160.
} 
Embora feitas para compreensão imediata, as charges se tornaram um importante instrumento de intervenção política cuja importância ultrapassava o riso fugaz. A respeito desse tipo de fonte, escreveu Rodrigo Patto Sá Motta,

\begin{abstract}
A fácil adaptação da caricatura ao discurso jornalístico deveu-se [...] ao fato de ter funcionado como crônica política. O desenho de humor, de maneira recorrente, atua no comentário diário dos acontecimentos e atos dos líderes políticos, o que auxilia os jornais em seu papel de produzir a notícia a informar o grande público. Com frequência, as caricaturas servem para expressar o ponto de vista do periódico sobre os temas em debate, como se ilustrassem a posição política do jornal. Cartum editorial é o nome usado nas redações para designar esse tipo de imagem que, através dos recursos de linguagem característicos do desenho cômico, ilustra e fixa as diretrizes políticas dos dirigentes dos veículos. ${ }^{253}$
\end{abstract}

No caso específico de Tribuna da Imprensa, o periódico lançou, entre dezembro de 1949 e o final do ano de 1955, cerca de mil e oitocentos números. Verificando-os em sua totalidade, nota-se que em pelo menos cinquenta em dois havia charges com referências nítidas ao justicialismo, totalizando cerca de 2,9\% dos exemplares. Como se pode notar, o assunto não foi um dos preferidos dos chargistas da redação. No entanto, esses desenhos satíricos parecem uma fonte importante na medida em que podem ter alcançado o público de maneira impactante, imediata e diferente dos discursos políticos tradicionais. A mordacidade das charges deve ter incomodado bastante os atingidos e satisfeito aqueles que se identificavam com os propósitos ideológicos do diário.

No período em tela, a imensa maioria das charges políticas antiperonistas publicadas em Tribuna da Imprensa foram assinadas pela chargista e artista plástica Hilde Weber (1913-1994). Nascida e formada na Alemanha, ela imigrou ao Brasil em 1933 e passou por vários jornais e revistas do Rio de Janeiro, entre eles os dos Diários Associados de Assis Chateaubriand. Em 1950, foi contratada por Carlos Lacerda para atuar em seu recém-lançado jornal. Ali, ela publicou quase que diariamente suas caricaturas até 1962, quando se transferiu para $O$ Estado de $S$. Paulo, onde trabalhou até se aposentar em 1989.

Dona de um estilo sintético, de "ar apressado" e traços fortes, ela comentou, em um depoimento colhido por Herman Lima, algumas de suas preferências como artista: “O desenho a traço, que é o mais puro, é sinônimo de 'eliminar': desenhar a traço é

\footnotetext{
${ }^{253}$ MOTTA, Rodrigo Patto Sá. Jango e o golpe de 1964 na caricatura. Rio de Janeiro: J. Zahar, 2006, p.
} 19. 
dizer tudo com pouco". ${ }^{254}$ Sua obra também foi definida por Fernando Pedreira na apresentação do livro Hilde - O Brasil em charges (1950-1985). Nas palavras deste,

[...] o seu estilo é surpreendentemente constante e fiel à si mesmo. Não parece haver nos seus desenhos inquietação, pesquisa formal e, ainda menos, a deliberada versatilidade criadora de um Chico Caruso ou do mestre Millôr Fernandes. A personalidade de Hilde é estável. Tranquila, firme como um barco seguro de sua rota. Mas ela se separa dos seus colegas brasileiros (também dos mais antigos como J. Carlos ou Calixto), talvez mais ainda pelas suas origens artísticas. Hilde descende do expressionismo alemão, de um George Crosz [sic], embora as charges não tenham em geral nem a virulência, nem a consciência social antiburguesa, que tanto marcaram os grandes expressionistas europeus. ${ }^{255}$

Para críticos, suas charges, embora bastante ferinas, não costumavam ser tão cruéis quanto as de alguns de seus contemporâneos e guardavam certa graça e delicadeza, mesmo em assuntos mais áridos. "Nunca fui do tipo venenosa e mordaz", assegurou em entrevista concedida em $1987 .{ }^{256}$

Em relação à sua postura ideológica, Rodrigo Patto Sá Motta notou que, em consonância com o projeto de Tribuna da Imprensa, a obra de Hilde se aproxima do ideal liberal e possuí características marcadamente antiesquerdistas e anticomunistas. ${ }^{257}$ Antes que Lacerda tivesse seus direitos cassados pela ditadura militar, por exemplo, ela chegou a produzir desenhos exaltando sua atuação política e defendendo sua candidatura presidencial. ${ }^{258}$

Não é possível, porém, aprofundar muito em suas posições políticas pessoais dada a pouca disponibilidade até o momento de material bibliográfico a esse respeito. Assim, é difícil saber ao certo em que medida tais charges ilustram a visão de mundo da artista ou a de seus colegas e chefes de redação. Em outros termos, as caricaturas eram solicitadas pela direção ou, na maioria das vezes, brotavam da cabeça da artista após as reuniões de pauta? Difícil saber. É provável que as duas situações fossem comuns. Afinal, jornais e revistas devem ser entendidos como empreendimentos coletivos de indivíduos que possuem um conjunto mínimo de valores políticos comuns, ou seja, certa comunhão ideológica. A esse respeito, comentou Sá Motta:

\footnotetext{
${ }^{254}$ LIMA, Herman. História da Caricatura no Brasil. Rio de Janeiro: José Olympio Ed., 1963, $4^{\circ}$ volume, p. 1604.

${ }^{255}$ WEBER, Hilde. O Brasil em charge: 1950-1985. São Paulo: Circo Editorial, 1986.

256، Perfil - Nos traços de Hilde, a vida política do Brasil” In Mulherio, São Paulo, julho 1987, ano VI, p. $12-13$

${ }^{257}$ MOTTA, 2006, op. cit., p. 12.

${ }^{258}$ Idem.
} 
Para além do fato óbvio de que o desenhista tem motivos para estar afinado com os valores defendidos pelo jornal - embora algum tipo de autonomia pudesse existir em certos casos - muitas caricaturas foram produtos de debates na redação, gerando ideias que acabaram corporificadas nos desenhos. A famosa representação de Carlos Lacerda como corvo nasceu assim, fruto de uma ideia de Samuel Wainer, dono do jornal Última Hora, que foi burilada e executada por Lan. Na redação de Tribuna da Imprensa, de Carlos Lacerda, também ocorreram situações semelhantes, de modo que algumas das charges de Hilde refletiam a contribuição da equipe de jornalistas. $^{259}$

Publicadas quase sempre na página quatro, as charges ocupavam um espaço nobre localizado imediatamente ao lado dos editoriais. Curiosamente, quase todas elas traziam um título na parte de cima, algo que com frequência interferia diretamente na interpretação da imagem.

Tal qual a própria Tribuna da Imprensa, Hilde Weber apresentou uma leitura bastante personalista das transformações pelas quais passava a Argentina. Por isso, a figura do presidente Perón foi quase onipresente quando o tema era o país vizinho. Alto para os padrões do período (com pouco mais de $1,80 \mathrm{~m})^{260}$, Perón foi retratado quase sempre com um longo nariz e com boca e queixo proeminentes. Frequentemente foi desenhado como um oficial longilíneo mas, em algumas ocasiões, também apareceu como um homem balofo e desalinhado. Como recurso para caracterizá-lo, Hilde lançou mão constantemente do recurso da faixa presidencial com a bandeira argentina que cruzava o peito e do tradicional quepe militar.

\subsection{A campanha presidencial de 1950}

$\mathrm{Na}$ imprensa brasileira, suspeitas a respeito de encontros ou de relações próximas entre Vargas e Perón foram publicadas, pelo menos, desde 1948. Esse ano foi marcado pela agitação política em torno do possível lançamento da candidatura do líder gaúcho às eleições presidenciais de 1950. A partir de então, o lema "Ele voltará" passou a ser estampado em santinhos, panfletos e cartazes varguistas. De acordo com a imprensa oposicionista, tais peças de propaganda teriam sido impressas em gráficas portenhas. Especulava-se também que os petebistas estariam recebendo dinheiro e até armas de Buenos Aires.

\footnotetext{
${ }^{259}$ Idem, p. 24.

260 De acordo com o verbete da Encyclopaedia Britannica, ver: http://www.britannica.com/EBchecked/topic/452378/Juan-Peron . Acesso em 04/01/2015.
} 
Em novembro daquele ano, o Diário da Noite, jornal carioca de Chateaubriand, lançou suspeitas sobre a determinação do governo platino em estabelecer ligações telefônicas entre São Borja e o país vizinho. Para o jornal, a medida facilitaria a comunicação entre os dois líderes sul-americanos, que contariam com o apoio do líder comunista Luís Carlos Prestes. A reportagem deixou patente a grande popularidade de Getúlio entre políticos e partidários justicialistas e atacou: "Com Prestes e Vargas, Perón forma o triângulo que encabeça a política de destruição da democracia no continente, usando como arma a exploração do trabalhador e o combate aos Estados Unidos [...]". ${ }^{261}$

Alguns elementos deram base aos insistentes rumores envolvendo os dois políticos sul-americanos. Vale lembrar que, mesmo eleito senador, Vargas solicitou seguidas licenças e passou a maior parte do governo Dutra na fazenda Itu, em Itaqui, Rio Grande do Sul, localizada a pouquíssimo quilômetros da fronteira com a Argentina. Perón, ainda que nunca tenha se encontrado com Vargas, também havia declarado repetidas vezes ser um admirador deste. Além disso, a imprensa ligada ao justicialismo costumava fazer elogios rasgados ao criador do Estado Novo e duras críticas ao governo Dutra. $^{262}$

No ano de 1948, em correspondência pessoal ao pai, Alzira Vargas, filha e assessora do político gaúcho, atribuiu inicialmente à imprensa brasileira a invenção de "coisas rocambolescas" que alimentavam os crescentes boatos de conspiração. ${ }^{263}$ Alguns dias depois, porém, admitiu que, inocentemente ou não, "os "nossos" estão contribuindo para isso". Apontou Lusardo como um dos responsáveis, pois suas constantes viagens de negócios entre o Rio de Janeiro, São Borja e Buenos Aires estariam reforçando a ideia de que ele agia como emissário entre Vargas e Perón. Além disso, o petebista Epitácio Pessoa Cavalcanti de Albuquerque (Epitacinho, filho do expresidente Epitácio Pessoa) estaria, após conversas com o embaixador argentino, a propalar, "com a discrição que lhe é habitual", que "tirará dinheiro dele [o embaixador]

\footnotetext{
${ }^{261}$ AGUIAR, Wilson. "Telefone direto entre S. Borja e B. Aires" In Diário da Noite, Rio de Janeiro, $16 / 11 / 1948$, p. 8.

${ }^{262}$ Em um editorial não assinado publicado no Correio da Manhãa, a atuação dos jornais argentinos foi duramente criticada: "Não contando com a imprensa democrática do Brasil, o getulismo desforra-se nas loas e fanfarras com que a imprensa escrava de Buenos Aires está saudando os seus sucessos eleitorais, não contente da grosseria com que, muito antes do pleito, vinha procurando intervir numa campanha política que só dizia respeito aos brasileiros". Ver: "Grosseria e insolência". Correio da Manhã, Rio de Janeiro, 10 de outubro de 1950. p. 1.

${ }^{263}$ Carta de Alzira Vargas do Amaral Peixoto a Getúlio Vargas de 9 de setembro de 1948. (CPDOC/RJ AVAP vpu e 1946.01.02)
} 
para uma campanha política quando quiser". Por fim, Alzira Vargas criticou o grupo queremista gaúcho, que estava "mandando imprimir cartazes de propaganda na Argentina por ser mais barato". Nesse sentido, afirmou: "mesmo [agindo] de boa fé, muita gente não acredita que seja esta a razão". ${ }^{264}$

Nessa mesma missiva, a herdeira de Vargas comentou que fora informada da existência de "um plano originado do Catete (Zé Lira), com o objetivo de te comprometer publicamente, como recebendo ou consentindo em um auxílio peronista a tua candidatura". Com a colaboração ou não de elementos ligados ao presidente Dutra, os boatos a respeito de um conluio permaneceram no ar e, como era de se esperar, afloraram com mais força à medida que a votação se aproximava.

Há no acervo pessoal de Vargas pelo menos quatro cartas sucintas trocadas com Perón no ano eleitoral. Em março, Perón informou a visita de João Goulart, com quem teria se colocado "perfeitamente de acordo". Declarou que estava ajudando a muita gente, que, invocando ser amigo de Vargas, o procurava solicitando diferentes tipos de favores. "Consenti sempre no entendimento de que servindo aos seus amigos, satisfaria a você", assegurou. Além disso, demonstrou a preocupação de que houvesse pessoas que, alegando serem representantes justicialistas, conseguissem vantagens de Vargas. Ao final, comentou:

\footnotetext{
Compartilho plenamente a opinião acerca do brilhante futuro do nosso continente, se conseguirmos unificar os esforços de todos os países que o formamos, em cujo favor não faremos omitir nenhum sacrifício realizável. Tenho inviável confiança no efetivismo da fraternidade americana e em direção a ele estará dirigido nosso maior empenho.

Receba meu estimado amigo, um cordial e grande abraço. ${ }^{265}$
}

Em abril, Perón acusou a visita de Epitacinho, que havia ido à Argentina com intuito de conhecer realizações peronistas e, nessa ocasião, foi portador de uma afetuosa carta de Vargas com elogios ao governo justicialista. ${ }^{266}$ Por fim, em uma missiva de 6 de julho de 1950, Perón comentou um encontro com Lusardo e desejou a Vargas sorte no pleito que estava por vir: "Eu penso como 'trabalhista' que 'ele voltará', assim

\footnotetext{
${ }^{264}$ Carta de Alzira Vargas do Amaral Peixoto a Getúlio Vargas de 13 de setembro de 1948 - (CPDOC/RJ - AVAP vpu e 1946.01.02).

${ }^{265}$ Carta de Juan Domingo Perón a Getúlio Vargas de março de 1950 (CPDOC/RJ - GV c 1950.03.00/3 GV c 1950.03.00/3).

${ }^{266}$ Carta de Juan Domingo Perón a Getúlio Vargas de 20 de abril de 1950 (CPDOC/RJ - GV c 1950.04.20/1). Ver também: Carta de Getúlio Vargas a Juan Perón de 11/03/1950 (CPDOC/RJ - GV c 1950.03.11).
} 
espero e assim desejo de todo coração". Em tom enigmático, mencionou projetos futuros envolvendo os dois países:

\begin{abstract}
Muito conversamos com Lusardo e compartilho totalmente seus pontos de vista sobre a amizade brasileiro-argentina e sobre o que no futuro pode construir-se sobre a base dessa amizade e esse entendimento completo. $\mathrm{O}$ amigo deputado Goulart o fará inteirado de tudo, que caminha muito bem. ${ }^{267}$
\end{abstract}

A imprensa de oposição não parecia alheia a essas conversas. Em janeiro de 1950, pouco mais de um mês após o lançamento de Tribuna da Imprensa, Hilde Weber desenhou Vargas e Perón tranquilamente tomando chimarrão nos pampas (figura 2). Juntos, parecem deliciar um churrasco com título "Departamento de Estado", órgão do governo norte-americano responsável pelas relações internacionais. Naquele momento, Getúlio Vargas continuava em sua fazenda em São Borja e astutamente não confirmava sua vontade de participar nas eleições vindouras, embora as especulações a respeito disso fossem constantes.

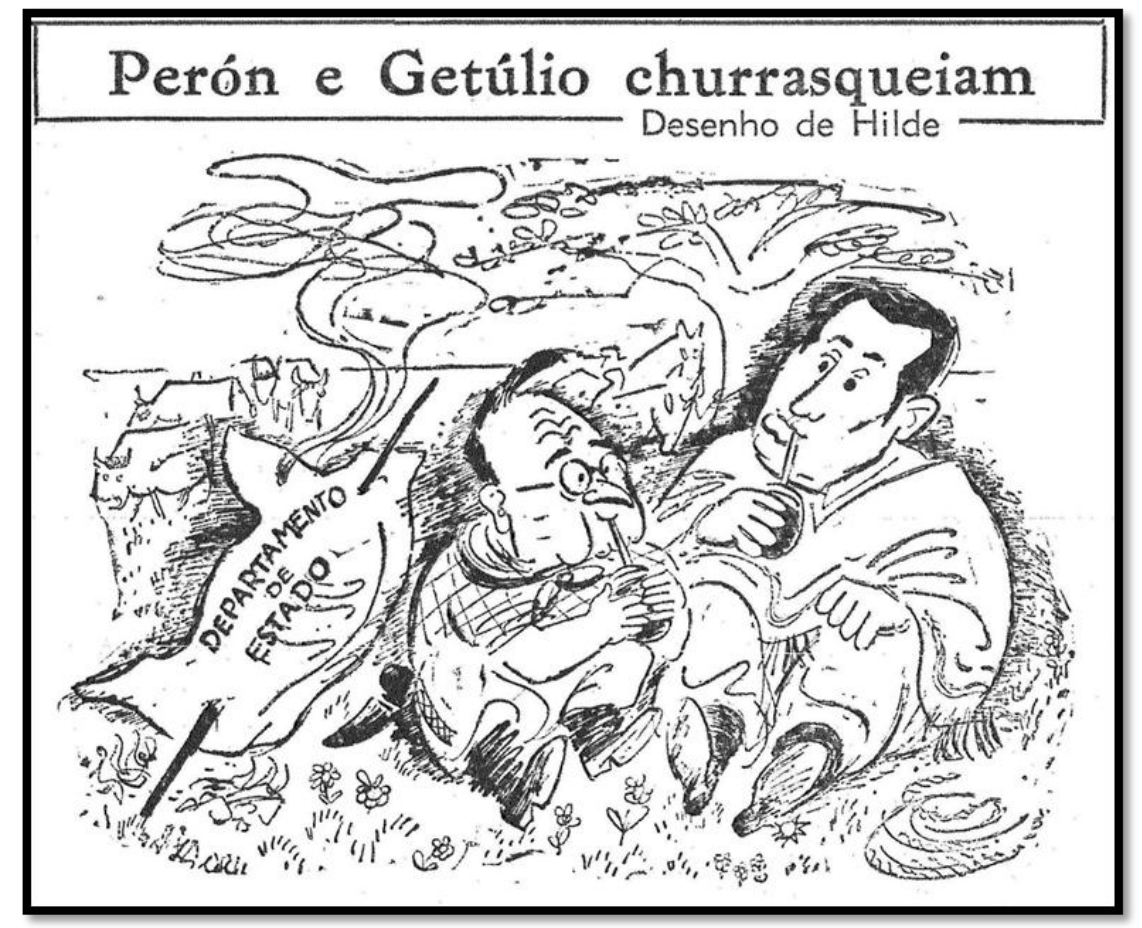

Figura 2 - HILDE. Tribuna da Imprensa, 25/1/1950, p. 4.

A charge aponta a postura contrária aos Estados Unidos por parte de ambos - os entendimentos secretos teriam por objetivo "devorar" os interesses de Washington na região. A retórica anti-estadunidense de Perón era bem conhecida, embora nem sempre

267 Carta de Juan Domingo Perón a Getúlio Vargas de 06 de julho de 1950 (CPDOC/RJ - GV c 1950.07.06). 
encontrasse respaldo nos ações cotidianas de seu governo. No caso de Vargas, a oposição ao Estado Novo por parte do Departamento de Estado, representado pela figura do embaixador Adolf A. Berle Jr., fora importante na transição para a democracia. ${ }^{268} \mathrm{Na}$ visão de Hilde, tal aproximação dos dois políticos sul-americanos representaria um retrocesso para os interesses norte-americanos.

Em junho de 1950, outra charge da artista alemã remeteu à ideia de conjura. Nela, Perón ensina planos a Getúlio Vargas, Luis Carlos Prestes e Ademar de Barros (figura 3). Uma semana antes, o controvertido governador de São Paulo anunciara, em um espetáculo público pomposo realizado na capital do estado, o que todos já sabiam desde o início do ano - ele daria amplo apoio ao postulante gaúcho. ${ }^{269}$

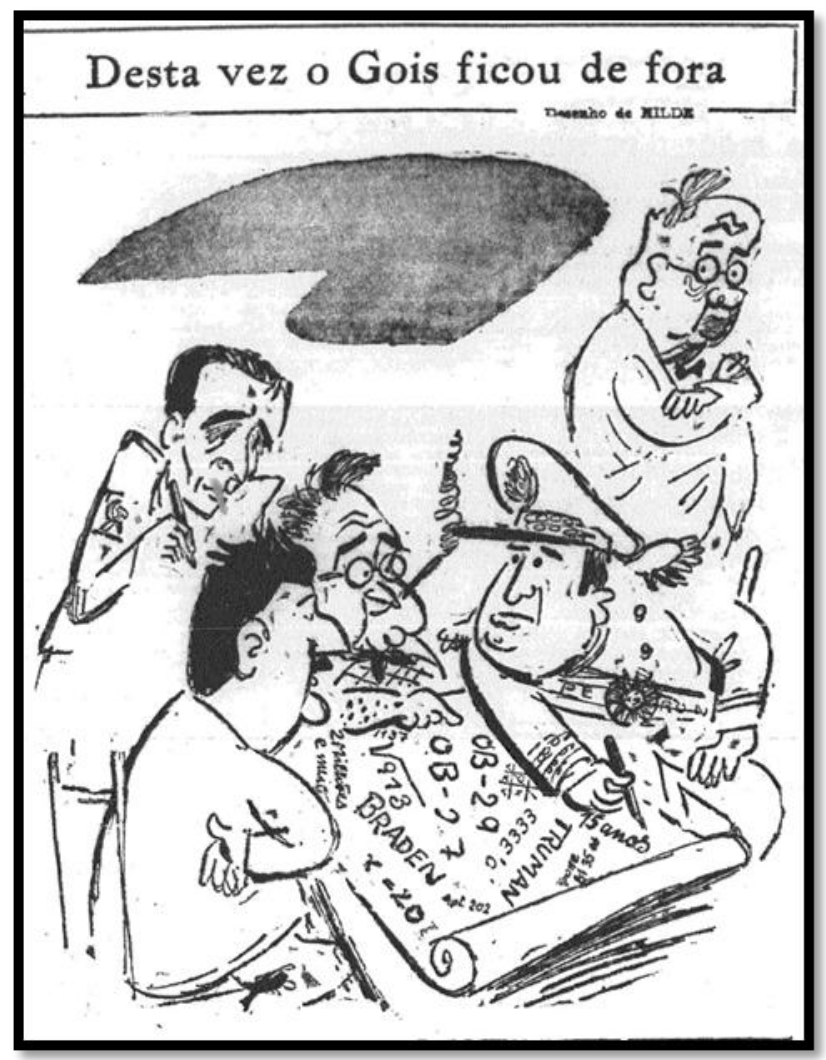

Figura 3 - HILDE. Tribuna da Imprensa, 22/06/1950, p. 4

\footnotetext{
${ }^{268}$ No final de setembro de 1945, Adolf Berle Jr. condenara publicamente a ideia de convocar a Constituinte com Vargas ainda no poder. Foi uma interferência clara dos norte-americanos que estavam preocupados com a possibilidade do presidente, através do queremismo, tentar uma manobra política que lhe garantisse continuidade no poder. Em 29 de outubro de 1945, o Estado Novo foi derrubado devido à insatisfação de setores conservadores e de uma parte do Exército. Receava-se também que se repetissem os eventos ocorridos na Praça de Maio, em Buenos Aires, doze dias antes ("Día de la Lealtad"). Ver: BANDEIRA, op. cit, p. 222-3.

${ }^{269}$ LIRA NETO, op. cit., p. 177-8.
} 
Góes Monteiro, que naquele momento era senador por Alagoas (PSD), aparece descontente por não ter sido convidado para a reunião. Figura central na implantação e organização do Estado Novo, período em que ocupou o cargo de Ministro da Guerra, ele andava distante politicamente de Vargas desde que liderara sua deposição em outubro de 1945. Em 1950, declarou seu apoio ao candidato do seu partido, Cristiano Machado, e em agosto rejeitou o convite de Vargas para ser seu candidato à vice-presidência na chapa PTB-PSP.

Embora empunhe um lápis, demonstrando sua possibilidade de contribuição, Luis Carlos Prestes aparece numa posição secundária, já que é o único no encontro não convidado a se sentar. Como se sabe, o PCB se achava proscrito do cenário político nacional desde 1947, num processo que curiosamente havia sido iniciado junto ao Tribunal Superior Eleitoral por dois deputados do PTB. Isolado, o partido na ilegalidade negou-se a apoiar qualquer candidato no pleito de 1950 e recomendou o voto em branco. Acredita-se, porém, que Vargas recebeu apoio de boa parte dos eleitores comunistas.

Numa interpretação possível, Hilde Weber buscou mostrar que Perón, que naqueles dias gozava de imensa popularidade em seu país, poderia inspirar projetos políticos autoritários no Brasil, especialmente aquele liderado por Vargas em aliança com líderes antidemocráticos como Prestes. Góes Monteiro, que participara de outros golpes, desta vez ficaria de fora.

Dando prosseguimento às suspeitas, o então chefe da Casa Militar do governo Dutra, Newton de Andrade Cavalcanti (1885-1965), anunciou, dois meses antes do pleito, que o governo teria provas das ligações entre Vargas e Perón e que este pretenderia "financiar a campanha política para restauração da ditadura". O PTB reagiu na voz de seu presidente, Danton Coelho, que disse que os supostos documentos eram "uma tentativa de um segundo plano Cohen". ${ }^{270}$ O ex-ministro da Guerra Góes Monteiro também criticou as declarações e sua divulgação salientando que elas poderiam motivar um conflito armado entre as duas nações. ${ }^{271}$ Até onde se sabe, o episódio não provocou desdobramentos mais graves. ${ }^{272}$

Lacerda, no entanto, não perdeu a oportunidade de atacar Vargas. Afirmou que ele era um homem “inflado por uma ambição senil e um desejo de desforra e destruição

\footnotetext{
270 “Ligação Perón-Vargas” In Tribuna da Imprensa, Rio de Janeiro, 10 de agosto de 1950, p. 1 e 2.

271 "Newton Cavalcanti” In Dicionário Histórico Biográfico Brasileiro pós 1930. 2a ed. Rio de Janeiro: Ed. FGV, 2001.

${ }^{272}$ BANDEIRA, op. cit., p. 250.
} 
que as suas blandícias já não escondem”. O jornalista reconheceu não possuir provas, mas assegurou: "Perón está profundamente ligado ao destino do movimento do sr. Getúlio Vargas". Acrescentou:

\begin{abstract}
A tolerância para com o sr. Getúlio Vargas, neste momento, significa a condescendência com um cúmplice de Perón. É preciso não esquecer que assim como Perón aprendeu com a ditadura do sr. Getúlio Vargas este modernizou muito o seu estilo ditatorial com as lições que lhe deu o marido da incandescente panfletária de Buenos Aires.

O sr. Getúlio Vargas encarna o peronismo no Brasil.

Aqueles que em nosso país quiserem indignar-se com os planos e processos pelos quais Perón procura destruir a amizade entre o Brasil e a Argentina, devem voltar os olhos para o sr. Getúlio Vargas. Pois aí é que está o perigo da traição.

Lá de fora, é apenas uma peronada.

Aqui dentro, é o que propriamente se pode chamar uma traição em marcha. ${ }^{273}$
\end{abstract}

Nos anos seguintes, Lacerda insistiria na ideia de que Perón inaugurara um novo tipo de ditadura muito mais efetiva porque mantinha a aparência democrática com base em eleições periódicas fraudadas e de um Congresso acuado. Para ele, os pendores autoritários de Vargas nunca teriam morrido e este buscaria criar um novo governo discricionário, semelhante ao da Argentina. Nessa perspectiva, eleger o político gaúcho significava "peronizar o Brasil". ${ }^{274}$

Em 3 de outubro de 1950, Vargas foi eleito com pouco menos de $49 \%$ dos votos válidos. Ainda que tenha aparecido com alguma força, a noção de que o político gaúcho era o "candidato argentino" - ou seja, apoiado pelo regime justicialista - parece ter influenciado muito pouco o pleito. Pode ter colaborado para isso a grande popularidade conseguida pelo presidente platino nos primeiros anos de seu primeiro mandato, malgrado as insistentes notícias negativas difundidas pelas agências de notícias internacionais e pelos meios de comunicação liberais-conservadores do Brasil.

A UDN não aceitou a voz das urnas. Com base em uma interpretação estreita da Constituição, o partido encampou a tese da que o candidato vencedor não atingira a maioria absoluta dos votos e que, portanto, não podia ser empossado. Lacerda foi um dos maiores defensores dessa manobra. Com sua tradicional virulência, fustigou:

O sr. Getúlio Vargas não teve mais da metade da votação popular.

Portanto, não está eleito presidente da República.

\footnotetext{
${ }^{273}$ LACERDA, Carlos. "Traição à vista” In Tribuna da Imprensa. Rio de Janeiro, 10 de agosto de 1950, p. 4.

${ }^{274}$ LACERDA, Carlos. “A conspiração” In Tribuna da Imprensa, Rio de Janeiro, 20/06/1950, p. 4.
} 
Quem não quiser a guerra civil, quem não quiser dias de sangue e de luto para este país, dias de vergonha e de amargura, dê agora - ao menos agora! uma prova de sensibilidade política, após tantos erros e hesitações: apoie a tese da maioria absoluta.

Ela é a porta pela qual o Brasil pode sair da antecâmara da ditadura. A não ser que prefira sair mais tarde, aos empurrões, pela janela.

Pois aos 69 anos de idade um ditador não muda de temperamento nem de vocação. Nem mudam os vorazes urubus que o cercam porque sabem que para onde ele vai, haverá carniça. ${ }^{275}$

Semanas após as eleições, Tribuna da Imprensa publicou uma charge que remetia à ideia do presidente argentino como ventríloquo a manipular políticos brasileiros que agiriam como marionetes, guiados por uma vontade alheia à sua. De novo, insinua-se a ideia de uma conspiração/conluio/conjura liderada por alguém poderoso que age fora dos holofotes.

$\mathrm{Na}$ charge (figura 4), denunciou-se o êxito do "candidato argentino", que agora estaria nas mãos do seu patrocinador. Vargas, com roupa de palhaço, não passaria de um títere sem personalidade guiado pelo tirânico líder argentino. Assim, os destinos do país teriam sido vendidos ao estrangeiro e Perón passaria a ser o presidente de fato do país.

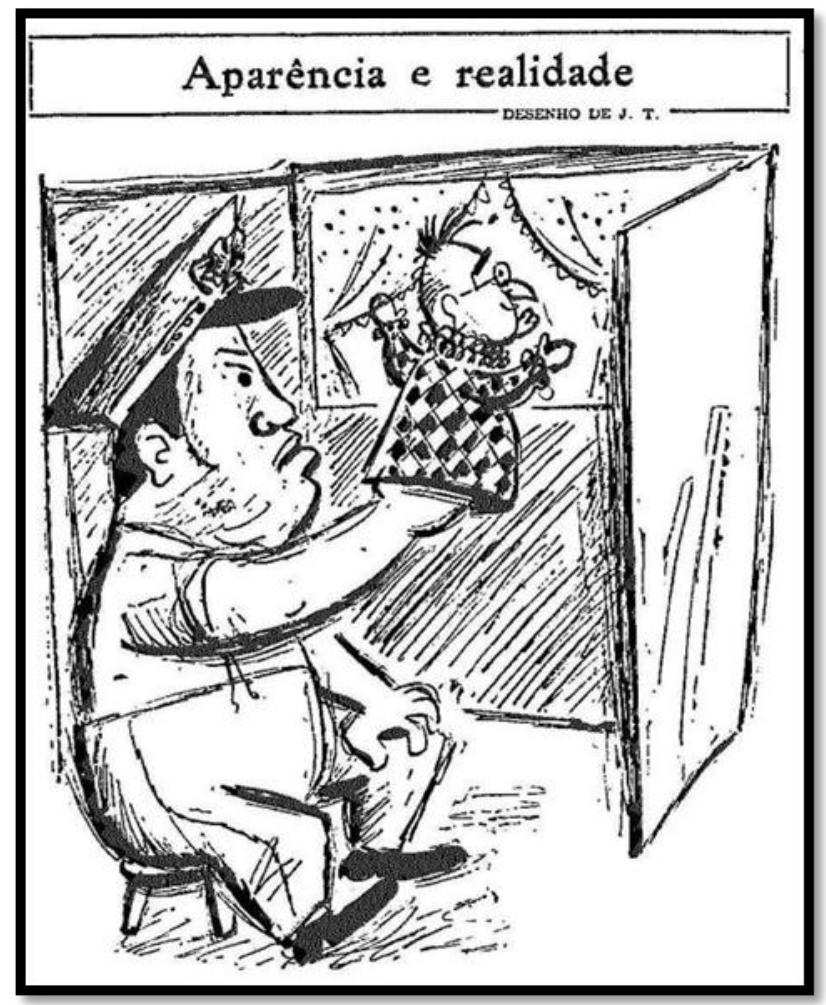

Figura 4 - J. T.. Tribuna da Imprensa, 21/11/1950, p. 4

${ }^{275}$ LACERDA, Carlos. “A traição em marcha” In Tribuna da Imprensa, Rio de Janeiro, 10/11/1950, p. 4. 
Vargas passou o intervalo de três meses entre o pleito e a posse em uma fazenda em Uruguaiana, Rio Grande do Sul, de propriedade de João Batista Lusardo, exembaixador na Argentina e amigo pessoal de Perón. Ao chegar à capital portenha, em maio de 1946, Lusardo fora recebido na estação ferroviária pelo casal Perón e por enorme multidão, numa demonstração de apreço pessoal e também da vontade argentina em se acercar do vizinho. ${ }^{276}$ Todavia, a aproximação de Dutra com a UDN levo-o a ser demitido em fevereiro de 1947.

A saída do embaixador não foi suficiente para aplacar os constantes ataques dos meios de comunicação opositores e de antiperonistas argentinos exilados, como Agustín Rodriguez Araya. Nos anos seguintes, eles continuaram questionando a proximidade de Lusardo com o presidente e a primeira-dama e, insistentemente, o acusaram de enriquecimento ilícito em solo platino. ${ }^{277}$ Para David Nasser, por exemplo, ele trabalhara para Perón, e não para o Brasil. O jornalista o apontou também como um dos "nossos lavais" 278 , aqueles que comporiam o grupo de "brasileiros que estão vendendo a sua pátria a uma nação vizinha". ${ }^{279}$ Lacerda não ficou atrás. Alegou que Perón era amo e sócio de Lusardo, a quem classificou, entre outras coisas, como "repulsivo"280, "contrabandista"281, "ignóbil"282 e "ladrão". 283

Durante e após a campanha de 1950, a relação entre Lusardo e Vargas deu margem a suspeitas em torno de uma aproximação deste com o líder argentino. O exembaixador, afinal, declarava abertamente grande admiração por Perón. Tais desconfianças se ampliaram nos primeiros dias de janeiro de 1951, quando Vargas, que continuava na fazenda de Lusardo, recebeu a visita de uma comitiva de políticos e militares peronistas liderada pelo vice-presidente, Hortencio Quijano. De acordo com Iuri Cavlak, até mesmo a embaixada brasileira em Buenos Aires suspeitava que o

\footnotetext{
${ }^{276}$ CARNEIRO, op. cit., p. 391.

277 NASSER, David e MANZON, Jean. "Bancarrota Argentina" In O Cruzeiro, Rio de Janeiro, 12/2/1949.

${ }^{278}$ NASSER, David. Perón insulta o Brasil: "Uma república de bêbedos" In O Cruzeiro, Rio de Janeiro, 7/10/1950.

${ }^{279}$ NASSER, David e MANZON, Jean. "Luzardo x Pereira Lira. Inquérito da traição" In O Cruzeiro, Rio de Janeiro, 24/06/1950.

${ }^{280}$ LACERDA, Carlos. "O Itamarati, o trust da Orquima e a tradição brasileira” In Tribuna da Imprensa, Rio de Janeiro, 9 de março de 1951, p. 4.

${ }^{281}$ LACERDA, Carlos. "A traição em marcha” In Tribuna da Imprensa, Rio de Janeiro, 10/11/1950, p. 4

282 LACERDA, Carlos. "Terror branco na Argentina" In Tribuna da Imprensa, Rio de Janeiro, 13/10/1951, p. 4.

${ }^{283}$ LACERDA, Carlos "Juarez é a salvação do Brasil pelo voto" In Tribuna da Imprensa, Rio de Janeiro, $1-2 / 10 / 1955$, p. 4.
} 
governo platino estivesse oferecendo ajuda material para garantir a posse de Vargas em caso de revolta militar. ${ }^{284} \mathrm{O}$ mesmo boato circulou no meio político da capital.

Em sua autobiografia, Batista Lusardo narrou que a comitiva chegou sem aviso prévio e que o vice-presidente argentino e o presidente eleito brasileiro teriam conversado reservadamente durante cerca de quatro horas. Questionado sobre o motivo da missão, o ex-embaixador em Buenos Aires redarguiu:

\footnotetext{
Se Perón ofereceu ajuda para garantir a posse de Getúlio, através de mim não foi. Mas duvido. Quanto à visita de Hortencio Quijano, se foi por intermédio dele, também não sei. Não creio, porém, que Perón oferecesse e muito menos que Vargas aceitasse coisa assim. Conhecendo esses homens, como os conheci, sinceramente não creio - contesto isso. Getúlio me disse que Quijano o cumprimentara pela vitória e lhe transmitira novo convite de Perón para que os dois presidentes se encontrassem oportunamente. ${ }^{285}$
}

Dias depois, durante uma cavalgada matinal, Lusardo teria questionado Vargas a respeito da rejeição à solicitação do presidente argentino em torno de um encontro ao vivo, sem intermediários. Enigmaticamente, este teria respondido: “Ah, "seu” Lusardo, esse milicos, esse milicos - com eles não se brinca...”. Na interpretação do exembaixador, Vargas teria evitado se reunir com Perón por temer que isso levasse os militares brasileiros a derrubá-lo novamente. ${ }^{286}$

Sem interferência da caserna, a solução veio em 18 de janeiro de 1951, quando o Tribunal Superior Eleitoral (TSE) fez pronunciamento favorável à sua posse. O clima de tensão após as eleições, porém, mostrava que o novo presidente não teria vida fácil nos anos seguintes.

\subsection{Perón e a liberdade de imprensa}

Um dos principais temas dos jornais liberais-conservadores foi o autoritarismo do regime argentino em relação à imprensa. Para esses diários, explorar esse flanco débil do justicialismo era uma forma de denunciar a ilegitimidade do governo platino e seu respeito superficial pela democracia. Para além do corporativismo dos periodistas, a liberdade de expressão era um assunto importante, que interessava ao cenário político do Brasil, país que abolira a censura prévia há menos de uma década.

\footnotetext{
${ }^{284}$ CAVLAK, op. cit., p. 140.

${ }^{285}$ CARNEIRO, op. cit., p. 359.

${ }^{286}$ Ibidem, p. 443.
} 
Se Vargas realmente tivesse por objetivo implantar o "peronismo tupiniquim"287, os donos de jornais teriam muito com o que se preocupar. Foi o que afirmou Lacerda menos de três meses após sua posse, quando o Congresso argentino, amplamente controlado pelos justicialistas, aprovou a expropriação de La Prensa. Não se tratava de um periódico qualquer, mas de um tradicional matutino que, nas palavras do historiador norte-americano James Cane, figurava como "o mais poderoso jornal comercial da América Latina". 288

Para os opositores do peronismo, a violência contra La Prensa era mais um sinal inequívoco dos pendores autoritários do governo argentino. Para os apoiadores, tratavase de um ato revolucionário altamente simbólico, porque derrubava um dos pilares das oligarquias. A medida teve ampla repercussão em todo mundo ocidental. De certa forma, porém, destoava um pouco da política adotada pelos justicialistas até então.

Se a prisão e posterior aclamação pública de Perón pela multidão que ocupou a frente da Casa Rosada, em 17 de outubro de 1945, havia demonstrado sua enorme popularidade, deixou claro também seu desamparo midiático. Os jornais da grande imprensa de Buenos Aires aplaudiram quase unanimemente o encarceramento do então secretário do Trabalho. Entre os periódicos mais influentes, a exceção ficou por conta de recém-criado vespertino, La Época. ${ }^{289}$ A oposição jornalística ao candidato do regime militar continuou, mas foi incapaz de impedir que no ano seguinte ele se saísse vencedor nas primeiras eleições democráticas em quase duas décadas. ${ }^{290}$

Ao tomar posse, Perón deparou-se não apenas com um Estado em ótimas condições financeiras, mas também com uma série de empresas jornalísticas em crise. Muitas delas buscavam tropegamente continuar existindo diante do aumento exorbitante do preço do papel-jornal importado e dos custos laborais, que tinham se acentuado com a criação de medidas favoráveis aos trabalhadores. Nos primeiros anos de seu mandato, o Estado e os aliados mais próximos do presidente começaram a comprar empresas jornalísticas deficitárias, tornando-as decididamente partidárias. Evitou-se inicialmente as expropriações e o empastelamento de diários.

Alguns jornais e revistas, embora tenham continuado a pertencer formalmente a seus antigos donos, reorientaram sua posição política em favor do peronismo após

\footnotetext{
${ }^{287}$ LACERDA, Carlos. "Nenhuma violação à Lei Eleitoral" Tribuna da Imprensa, Rio de Janeiro, 4/10/1955, p. 4.

${ }^{288}$ CANE, James. The fourth enemy. Journalism and Power in the making of peronist Argentina, 19301955. The Pennsylvania State University, Pennsylvania, 2011, p. 1.

${ }^{289}$ Ibidem, p. 177.

${ }^{290}$ Ibidem, p. 178.
} 
compromissos feitos, frequentemente, por razões muito mais materiais do que ideológicas. Poderoso, o Estado argentino controlava os empréstimos e os subsídios às empresas, a venda do papel-jornal, a fiscalização nos locais de trabalho, a enorme publicidade oficial e os sindicatos de trabalhadores.

Nas palavras de James Cane, Perón não procurou cultivar aliados entre os donos de jornal, mas produzir dependentes incapazes de traição. ${ }^{291}$ Para alguns empresários, o alinhamento ideológico ao justicialismo foi a proteção encontrada diante de um mercado cada vez mais hostil e em vias de concentração. Para não desapareceram, muitos se curvaram ao peronismo.

$\mathrm{O}$ avanço do peronismo se deu também no nível discursivo. Embora os diários liberais tradicionais se colocassem como expressões máximas da "opinião pública", os eventos de outubro de 1945 deixaram claro que grupos muito importantes estavam, no mínimo, sub-representados na imprensa argentina. Ao justificar o avanço do Estado em relação à mídia, os justicialistas afirmaram que era necessário promover uma distribuição mais justa dos meios de comunicação, garantindo o direito de expressão aos trabalhadores e dando voz a setores tradicionalmente esquecidos. Na sua perspectiva, isso consolidaria uma cidadania mais efetiva. Além disso, os aspectos comerciais da imprensa tradicional subverteriam os objetivos culturais e informativos do jornalismo. $^{292}$

Em poucos anos, o regime construiu algo sem precedentes na região, um enorme aparato paraestatal e semioficial, definido por James Cane como o "maior império de mídia da América Latina". ${ }^{293}$ Dezenas de rádios, revistas e quatro dos cinco jornais de maior circulação do país em 1946 já estavam nas mãos do justicialismo e de seus aliados em 1951. ${ }^{294}$ Aos poucos, consolidou-se na imprensa peronista certa homogeneização de um monótono discurso laudatório em torno do regime, cuja produção era parcialmente centralizada pela Subsecretaría de Información y Prensa, órgão que se tornou muito poderoso e que, não por acaso, também era responsável pela propaganda do governo. ${ }^{295}$ A postura evidentemente autoritária foi destacada por Cane:

\footnotetext{
${ }^{291}$ Ibidem, p. 184.

${ }^{292}$ Ibidem, p. 177-178.

293 Ibidem, p. 228.

294 Ibidem, p. 3.

${ }^{295}$ Claudio Panella apontou, porém, que jornais apresentavam alguma variação de enfoque, pois refletiam ações e pensamentos de diferentes líderes e segmentos do movimento. Ver: PANELLA, 2007, op. cit., p. 16.
} 
A despeito de suas afirmações de que teriam "libertado" a imprensa, Perón e seus aliados criaram uma indústria de jornais fortemente controlada, dependente e encarregada da tarefa de gerar consenso ao invés de servir como um fórum de expressão das opiniões dos cidadãos. ${ }^{296}$

Ainda assim, o silenciamento puro e simples de jornais adversários tinha sido uma estratégia utilizada em menor escala quando estourou o conflito com La Prensa. Nascido em 1869, o matutino se destacava por ser um baluarte das elites argentinas e do liberalismo econômico. Desde o início, foi profundamente contrário à política peronista. Sua tiragem impressiona. No ano em que Perón foi eleito, a edição de domingo saía com meio milhão de exemplares, maior do que qualquer outro diário do continente, excetuando os norte-americanos. ${ }^{297}$ Seu proprietário e diretor, Alberto Gainza Paz, era um homem rico e com amigos poderosos no país e no exterior.

Com uma situação econômica relativamente boa, La Prensa pôde resistir por mais tempo às investidas do peronismo. De acordo com Pablo Sirvén, o periódico sofreu com as constantes inspeções governamentais em busca de contravenções contábeis, trabalhistas, sanitárias e de outros tipos. ${ }^{298}$ Em 1946, em meio à crise de importação de papel-jornal, teve parte de seu estoque expropriado. ${ }^{299}$ A escassez dessa matéria-prima, cuja importação passara a ser controlada pelo Estado, prejudicou também seus ganhos com publicidade e especialmente os classificados, sobre o qual possuía virtual monopólio do mercado. ${ }^{300}$

O derradeiro embate estourou em janeiro de 1951, quando o Sindicato de Vendedores de Diários, Revistas e Afines liderou uma greve que exigia o pagamento de $20 \%$ do lucro dos anúncios classificados à categoria. Após um impasse e graves conflitos, que resultaram na morte de um trabalhador e na interrupção da circulação por semanas, membros do Congresso criaram uma comissão mista para investigar o jornal. Dominado por peronistas, o grupo recomendou a expropriação da empresa, com base, entre outras coisas, em acusações de fraude ao fisco e associação espúrias com grupos de mídia internacional. ${ }^{301}$ A proposta acabou aprovada pelos deputados (98 votos contra 12) em abril. De acordo com a argumentação peronista, La Prensa possuía sentido meramente econômico, e não social, além de ser instrumento de exploração capitalista,

\footnotetext{
${ }^{296}$ CANE, op. cit., p. 205.

${ }^{297}$ Ibidem, p. 35.

298 SIRVÉN, Pablo. Perón y los medios de comunicación. La conflictiva relación de los gobiernos justicialistas com la prensa (1943-2011). $1^{\text {a }}$. edição, Buenos Aires, Sudamericana, 2011, p. 156.

${ }^{299}$ CANE, op. cit., p. 189.

${ }^{300}$ Ibidem, p. 192.

${ }^{301}$ SIRVEN, op. cit., p. 162-171.
} 
ao defender continuamente posições patronais. Nesse diapasão, a expropriação foi difundida como um ato revolucionário que visava acabar com o monopólio do jornalismo e redistribuir o poder de expressão.

Gainza Paz, que saíra clandestinamente do país durante o processo, soube meses depois que seu jornal seria entregue à CGT e ao sindicato que liderara a greve. De acordo com Pablo Sirvén, o que houve foi um confisco, já que o Estado não ressarciu seu antigo proprietário. ${ }^{302} \mathrm{~A}$ repercussão internacional foi proporcional à influência de La Prensa. Seguiu-se uma onda de manifestações de repúdio feitas por políticos, jornais e jornalistas, especialmente do mundo ocidental. Bandeiras foram colocadas a meio mastro em frente à maioria dos maiores diários dos Estados Unidos, Europa Ocidental e América Latina. ${ }^{303}$

Perón se manteve convenientemente afastado do processo conduzido pelo Congresso $^{304}$, que foi feito dentro da legalidade constitucional estabelecida pelo justicialismo. Isso não foi suficiente, porém, para maquiar o evidente viés discricionário da medida, que beneficiava diretamente o mandatário. Assim, embora vitorioso, o governo viu seus esforços para manter os ares de legitimidade e democracia do regime serem severamente arranhados. De acordo com Claudio Panella, La Prensa tornou-se um símbolo do autoritarismo do governo para todos os antiperonistas. ${ }^{305}$

Embora dominasse o cenário jornalístico e buscasse cada vez mais aprofundar o consenso justicialista, o governo permitiu que diários de oposição menos exacerbada continuassem existindo sem serem muito incomodados, como foi o caso de La Nación e Clarín. ${ }^{306}$ Ao longo dos anos, porém, o amplo domínio do aparato midiático estatal, que tirou da oposição poderosos canais de expressão, fez com que muitos antiperonistas passassem a cogitar saídas fora da legalidade estabelecida pelo regime. Ou seja, soluções armadas.

Meses antes do fechamento do diário argentino, Lacerda já assinara editorial intitulado "O papel, arma branca da ditadura", no qual apontava a licença de importação de papel-jornal como um dos principais instrumentos de controle dos governos sobre a imprensa. Para ele, Vargas, o "inimigo número um da liberdade de pensamento no Brasil”, ensinara muitas coisas a Perón, mas também aprendera bastante com este. Do

\footnotetext{
${ }^{302}$ Ibidem, p. 172-173.

${ }^{303}$ CANE, op. cit., p. 224.

${ }^{304}$ SIRVEN, op. cit., p. 162.

305 PANELLA, 2007, op. cit., p. 12.

${ }^{306}$ Ibidem, p. 18.
} 
seu ponto de vista, o político gaúcho estava prestes a repetir o que estava sendo feito no país vizinho, onde "quem não se submeter, não terá papel para imprimir notícias, comentários e anúncios". Segundo Lacerda, a não interferência do Estado na importação de papel-jornal era "condição fundamental para a existência de uma imprensa livre" e uma forma de evitar que houvesse o "calvários das liberdades públicas" e a "peronização do Brasil". 307

Quando La Prensa deixou de circular devido à greve dos vendedores de jornais, a Tribuna da Imprensa, em nome da direção e dos funcionários, expressou solidariedade à folha fechada e veemente reprovação aos "atropelos de um governo ditatorial". ${ }^{308}$ O próprio Lacerda assinou um telegrama de desaprovação destinado ao embaixador argentino, em que sustentava que "atos desse gênero contribuem para perturbar no exterior o conceito de que tradicionalmente goza a República Argentina como nação civilizada e incapaz de tolerar atos de barbárie dignos dos mais selvagens regimes totalitários". ${ }^{309}$ O jornalista udenista chegou a oferecer suas oficinas para a publicação de La Prensa no exílio. ${ }^{310}$ Em suas palavras,

\begin{abstract}
A agressão a "La Prensa" é agressão a todo jornal digno do nome de jornal. O crime contra "La Prensa" fere, no próprio rosto, a nobre nação argentina. E, se os argentinos não podem falar livremente, aqui estamos nós para falar por eles, como gostaríamos que por nós venham a falar se algum dia novamente, formos reduzidos ao silêncio que hoje, da redação de "La Prensa", se espalha sobre toda a América. 311
\end{abstract}

Lacerda, que afirmou ser amigo do "sereno e bravo diretor"312 do jornal argentino, derramou-se em elogios ao diário, tido como um "monumento da cultura continental"313, "honra e orgulho da imprensa contemporânea"314 e "consciência cívica dos argentinos" ${ }^{\prime 315}$. Rebateu, ainda, a acusação que era frequentemente feita à própria

\footnotetext{
${ }^{307}$ LACERDA, Carlos. "O papel, arma branca da ditadura" In Tribuna da Imprensa, Rio de Janeiro, 30 de outubro de 1950, p. 4.

308 "Solidariedade a "La Prensa". Tribuna da Imprensa, Rio de Janeiro, 3-4 de março de 1951, p. 1.

309 “Alvejados os trabalhadores de "La Prensa"”. Tribuna da Imprensa, Rio de Janeiro, 28/2/1951, p. 1 e 10 .

310 "Um lugar para "La Prensa" nos jornais brasileiros". Tribuna da Imprensa, Rio de Janeiro, 15/03/1951, p. 1 .

${ }^{311}$ LACERDA, Carlos. “Agredir a liberdade de imprensa é atentar contra a paz” In Tribuna da Imprensa, Rio de Janeiro, 10-11 de fevereiro de 1951, p. 4.

312 Ibidem

${ }^{313}$ LACERDA, Carlos. "La Prensa e o interesse do Brasil”" In Tribuna da Imprensa, Rio de Janeiro, 15 de março de 1951, p. 4.

${ }^{314}$ Ibidem.

${ }^{315}$ LACERDA, Carlos. “Agredir a liberdade de imprensa é atentar contra a paz” In Tribuna da Imprensa, Rio de Janeiro, 10-11 de fevereiro de 1951, p. 4.
} 
Tribuna da Imprensa, a ideia de que La Prensa estava vinculada a interesses estrangeiros. Ele escreveu: “[...] Conhecemos muito bem essa calúnia - e cuspimos nela o nosso desprezo, pois nada do que se possa inventar altera ou entibia a nossa disposição de defender a verdade e de proclamá-la como é do nosso dever elementar".316

Cobrou, também, providências diplomáticas, ao argumentar que o País deveria apoiar um pronunciamento da ONU sobre o caso ${ }^{317}$. Aduziu que o Itamaraty tinha obrigação de convocar o embaixador argentino no Rio de Janeiro para lhe fazer ver o quanto a situação "enche de apreensões o povo e governo do Brasil",318. Ao notar a relutância dos responsáveis pelas relações exteriores em adotar uma postura mais ativa contra "a marcha totalitária do Governo argentino", Lacerda fustigou:

[...] Essa ataraxia, essa perplexidade, essa esquivança da chancelaria, porém, tem suas razões e suas raízes. As raízes encontram-se nas ligações inequívocas do sr. Getúlio Vargas com o regime de Perón, modelado pelo seu Estado Novo, por sua vez cópia dos regimes totalitários de tipo europeu. ${ }^{319}$

Lacerda especulou que o silêncio das autoridades brasileiras fazia parte de uma encenação na qual o País simulava entendimentos mais profundos com Perón para obter vantagens materiais dos norte-americanos durante as negociações da Conferência de Washington, entre março e abril de 1951. Dessa forma, "julgam esses maquiáveis de bolso [que] os Estados Unidos cairão com dinheiro para sustentar a polícia faustosa e aparatosa do sr. Vargas" 320 . Lacerda classificou tal estratégia como "chantagista"321 e defendeu um alinhamento leal e irrestrito à "civilização fundada na liberdade". 322

Nas páginas de O Cruzeiro, o caso La Prensa também provocou reações indignadas. Ao escrever sobre o caso, Agustín Rodriguez Araya, exilado no Uruguai, usou termos como "um monstruoso crime" e "holocausto da imprensa". ${ }^{323}$ Franklin de Oliveira falou em "garroteamento da liberdade"324 e imolação do diário em um

\footnotetext{
${ }^{316}$ Idem.

${ }^{317}$ Idem

${ }^{318}$ LACERDA, Carlos. "O Itamarati, o trust da Orquima e a tradição brasileira" In Tribuna da Imprensa, Rio de Janeiro, 9 de março de 1951, p. 4.

${ }^{319}$ Idem.

${ }^{320}$ Idem.

${ }^{321}$ Idem.

${ }^{322}$ Idem.

${ }^{323}$ RODRIGUEZ-ARAYA, Agustin e KEFFEL, Ed. "La Prensa - O baluarte ultrajado" In O Cruzeiro, Rio de Janeiro, 5/5/1951, p. 95, 96, 97, 98, 99, 100, 104 e 112.

${ }^{324}$ OLIVEIRA, Franklin de. "Os mortos ceiam" In O Cruzeiro, Rio de Janeiro, 24.02.1951, p. 7.
} 
pelourinho. Ademais, questionou: "Em holocausto de que deuses este sacrifício, senão em homenagem às forças demoníacas da servidão e do obscurantismo?". 325

O tom geral foi de que o ocorrido confirmava o viés ditatorial do peronismo. Rachel de Queiróz afirmou que "todo ditador é um outlaw" [fora da lei] e que "um Franco, um Perón, um Stálin, procedem e vivem dentro do mesmo estado de espírito do nosso falecido patrício Virgulino Ferreira, o Lampião". ${ }^{326}$ Já o cronista político Franklin de Oliveira defendeu a exclusão da Argentina da Conferência de Washington, apontada como um "parlamento internacional da livre América". ${ }^{327}$ Para ele, "nas democracia modernas, a imprensa está destinada a desempenhar o papel de ágora ateniense e fórum romano". ${ }^{328}$ Convidado a narrar a história e o destino do jornal e de seu proprietário, Rodriguez Araya enalteceu Gainza Paz, citou a amizade deste com Chateaubriand e disse ser "inteiramente falso" o argumento peronista de que La Prensa era um órgão de classe ou de inspiração partidária. ${ }^{329}$

Muitos cronistas políticos, incluindo Lacerda, lançaram mão da ideia de que o peronismo era um retrocesso à barbárie, ou seja, o abandono dos valores da civilização ocidental. Ao relembrar sua visita a La Prensa, a escritora Lausimar Laus (1916-1979) descreveu-o como "um "delicioso mundo do pensamento livre, onde se buscam os grandes caminhos para uma civilização purificada de vingança, de brutalidade e de extremismos". 330

A grande repercussão da expropriação de La Prensa no mundo ocidental provocou amplo desgaste da imagem do governo argentino e a reabilitação temporária do clima de tensão com os Estados Unidos. De acordo com José Paradiso, a relação vinha melhorando desde o ano anterior, quando, em uma situação econômica menos confortável, o país conseguira vultoso empréstimo de Washington. Com o fechamento do jornal, no entanto, os funcionários da diplomacia norte-americana "não puderam deixar de ecoar a estridente solidariedade dos diários norte-americanos com o colega

\footnotetext{
${ }^{325}$ OLIVEIRA, Franklin. "Violência e ignomínia". Coluna Sete Dias In: O Cruzeiro, Rio de Janeiro, 17 de março de 1951, p. 7.

${ }^{326}$ QUEIROZ, Rachel de. “O drama de "La prensa"” In O Cruzeiro, Rio de Janeiro, 21/04/1951, p. 130.

327 OLIVEIRA, Franklin. "Violência e ignomínia". Coluna Sete Dias In: O Cruzeiro, Rio de Janeiro, 17 de março de 1951, p. 7.

328 Ibidem.

${ }^{329}$ RODRIGUEZ-ARAYA, Agustin e KEFFEL, Ed. "La Prensa - O baluarte ultrajado" In O Cruzeiro, Rio de Janeiro, 5/5/1951.

${ }^{330}$ LAUS, Lausimar. “Uma brasileira visita La Prensa” In O Cruzeiro, Rio de Janeiro, 24/3/1951, p. 3.
} 
portenho [Gainza Paz] e a pressão dos setores liberais que viam confirmadas suas antigas prevenções a respeito do mandatário argentino e de seu regime". 331

Ainda segundo Paradiso, o endurecimento interno na Argentina teria sido uma manobra calculada, pois eleições presidenciais seriam realizadas no final de 1951, em um quadro de crescente inflação e de diminuição das exportações e do crescimento econômico. A estratégia parece ter contribuído para sua reeleição, com pouco mais de $62 \%$ dos votos em novembro daquele ano. ${ }^{332}$

Um mês antes do pleito argentino, as relações entre o peronismo e a imprensa voltaram a inundar as páginas dos jornais brasileiros. Entre 8 e 12 de outubro de 1951, realizou-se em Montevidéu a sétima assembleia da Sociedade Interamericana de Imprensa, uma associação que congregava jornalistas e donos de jornais de várias partes do continente. De acordo com a Tribuna da Imprensa, o encontro debateria principalmente a escassez mundial de papel-jornal e a liberdade de expressão, com ênfase nas recentes expropriações ocorridas na Argentina. Eram temas bastante sensíveis para a Casa Rosada.

Havia então nove brasileiros já associados à entidade, entre os quais Lacerda e outros representantes de grandes jornais e cadeias, como os Diários Associados. ${ }^{333}$ Destoando do grupo, constava Georges Galvão, petebista proprietário de $O$ Radical, um pequeno diário ligado aos sindicatos e voltado ao público operário, o qual com frequência elogiava o governo justicialista.

De acordo com $O$ Cruzeiro, houve logo no primeiro dia uma grande confusão porque um grupo de aproximadamente sessenta pessoas, principalmente jornalistas argentinos não inscritos, tentou entrar na assembleia. Com eles, estavam alguns representantes de pequenos diários, definidos pela reportagem como "peronistas do Brasil e outros países das Américas do Sul e Central". ${ }^{334}$ O grupo foi inicialmente barrado. Segundo Lacerda, após muita confusão e discussão, a Sociedade resolveu admitir "sem quaisquer explicações", a entrada de apenas 11 dos 41 novos

\footnotetext{
${ }^{331}$ PARADISO, op. cit., p. 555.

${ }^{332}$ Ibidem, p. 556.

${ }^{333}$ Entre os brasileiros inscritos, estavam Paulo Bittencourt, proprietário do Correio da Manhã, Carlos Lacerda, da Tribuna da Imprensa, Herbert Moses, representando a ABI (Associação Brasileira de Imprensa) e $O$ Globo, Carlos Rizzini dos Diários Associados e Arlindo Pasqualini da Folha da Tarde de Porto Alegre. Ver: "Declaração dos brasileiros membros da Sociedade Interamericana de Imprensa". Tribuna da Imprensa, Rio de Janeiro, 11/10/1951, p. 6. De acordo com O Cruzeiro, havia ainda Giusfredo Santini, Antônio Ibrahim Haddad, Carlos Ripón e Alfredo C. Machado. Ver: SILVA, Camarinha da. "Fracasso dos peronistas da imprensa" In O Cruzeiro, Rio de Janeiro, 3/11/1951, p. 50.

${ }^{334}$ Ibidem.
} 
postulantes. ${ }^{335}$ Os demais teriam seus pedidos analisados depois do evento, "a fim de verificar a sua lealdade à causa da liberdade de imprensa". 336

Temia-se que os peronistas formassem a maioria e dominassem o encontro: "Enquanto os outros delegados americanos do Norte e do Sul manteriam por temperamento e por sistema suas opiniões individuais, os peronistas de todas as partes formariam um bloco de uma só opinião". 337

A admissão de apenas alguns jornalistas não aplacou os ânimos. No dia seguinte, Rizzo Barata, representante da revista $A h o r a^{338}$, fez um pronunciamento em plenário acusando a entidade de, entre outras coisas, "práticas ditatoriais na questão das credenciais e na admissão de novos membros" e de sobrepor interesses capitalistas à liberdade de imprensa. Após o discurso, houve a imediata retirada dos delegados platinos, acompanhados por alguns representantes de outros países latino-americanos, incluindo treze brasileiros que também estavam solicitando filiação. Ligados a pequenos diários, esses brasileiros assinaram um texto em que denunciavam a Sociedade Interamericana de Imprensa como "instrumento de monopólios jornalísticos". ${ }^{339} \mathrm{Na}$ liderança desse grupo dissidente estava Georges Galvão. A conferência seguiu com seus debates nos dias seguintes.

O Cruzeiro cobriu o evento e titulou sua reportagem, assinada por Camarinha da Silva, como "Fracasso dos peronistas da imprensa". Afirmou que o episódio fazia parte de uma estratégia golpista anteriormente orquestrada para dividir a Sociedade Interamericana de Imprensa. Lacerda foi ainda mais sulfúrico: "Saíram os gangsters, ficou a Assembleia". E emendou: "complot peronista contra a unidade da imprensa continental". Para ele, o país estaria bem representado pelos donos dos meios de

\footnotetext{
335 “Saíram os gangsters, ficou a Assembléia” In Tribuna da Imprensa, Rio de Janeiro, 10/10/1951, p. 1 e 10.

${ }^{337}$ De acordo com a Tribuna da Imprensa, os brasileiros que se retiraram foram: "Georges Galvão, de "O Radical", do Rio de Janeiro; Carlos Cavaco, do "Jornal do Povo", do Rio; Antônio Guedes de Holanda, de "Vanguarda"; Antônio de Paula, do "Diário do Rio"; Geraldo Cardozo, da "Folha do Rio"; Ítalo Saldanha da Gama, da "Gazeta de Notícias"; Normando Lopes, do "Diário do Povo"; Armando Santos, da "Força da Razão"; Leopoldo da Silva, da "Voz Trabalhista"; Luis de Freitas, do "Correio da Noite"; Reis Vidal, da Agência ARGUS; Maurício Marques Lisboa, de "O Mundo"; Carlos Vidigal, da agência "ASAPRESS"; e P. Nunes Arca, da"Asapress" e de "A Tribuna"”. Ver: "Saíram os gangsters, ficou a Assembléia" In Tribuna da Imprensa, Rio de Janeiro, 10/10/1951, p. 1 e 10.. O Cruzeiro acrescentou que estava nesse grupo Antônio Santos Forza, de "Raça".

${ }^{338}$ Ver: SILVA, Camarinha da. "Fracasso dos peronistas da imprensa" In O Cruzeiro, Rio de Janeiro, 3/11/1951, p. 50. Alguns jornais brasileiros se referiram ao meio de comunicação de Rizzo Barata como um jornal de nome "La Hora". Sabe-se que, ao contrário de "Ahora", "La Hora" era de orientação comunista.

339 "Saíram os gangsters, ficou a Assembléia". Tribuna da Imprensa, Rio de Janeiro, 10/10/1951, p. 4.
} 
comunicação que englobavam a maioria dos leitores. Os excluídos não passariam de "representantes de jornais sem significação". 340

A exclusão daqueles jornalistas foi justificada como uma forma de aplacar "o golpe de Perón visando dominar a associação". ${ }^{341}$ Nesse sentido, Lacerda insistiu bastante em apontar a atuação de "brasileiros venais na conspiração peronista". ${ }^{342}$ Alegou que Georges Galvão viera "a Montevidéu via Buenos Aires" e que reservas em hotéis de alguns colegas nacionais tinham sido feitas pela embaixada argentina. ${ }^{343}$ Embora tenha admitido que alguns dos jornalistas brasileiros rejeitados nada tinham de justicialistas, alegou que esses seriam "ingênuos" "344 e que teriam sido "arrastados pela sua inexperiência e vaidade". ${ }^{345}$ Acrescentou Lacerda:

\begin{abstract}
Lamentavelmente, alguns representantes de jornais brasileiros associaram-se ao jogo de Perón. De vários deles, não se poderia esperar outra coisa, tão conhecida é a sua escusa identificação com a ditadura argentina. Outros jornais, entretanto, com mais graves responsabilidades perante a opinião pública, órgãos ostensivos de organizações insusceptíveis de qualquer conivência com a corrupção peronista, surpreenderam os seus leitores com uma atitude que revela ligações até agora não suspeitadas.

De qualquer maneira, a Conferência continuará livre da desordem a que procurou conduzi-la o grupo jornalístico a soldo da ditadura argentina. E isto honra o espírito de liberdade da América. ${ }^{346}$
\end{abstract}

É razoável supor que os peronistas queriam, de fato, prejudicar o encontro da Sociedade às vésperas das eleições presidenciais argentinas. Naquele momento, não interessava ao governo platino qualquer resolução condenando sua política em relação à imprensa. De outro lado, a ênfase na ideia de uma conjuração buscava tirar o foco do critério evidentemente arbitrário utilizado na recusa da associação aos novos membros menos poderosos.

Hilde, que havia ficado no Rio de Janeiro, seguiu a interpretação de Lacerda aqueles abandonaram o evento não passavam de indivíduos financiados secretamente pelo governo argentino com intuito de controlar a entidade (figura 5). O "complot peronista" foi denunciado numa charge em que os periodistas platinos deixam o recinto

\footnotetext{
340 SILVA, Camarinha da. "Fracasso dos peronistas da imprensa" In O Cruzeiro, Rio de Janeiro, 3/11/1951, p. 50.

341 "Saíram os gangsters, ficou a Assembléia”. Tribuna da Imprensa, Rio de Janeiro, 10/10/1951, p. 1 e 10.

342 "Brasileiros venais na conspiração peronista contra a Assembléia". Tribuna da Imprensa, Rio de Janeiro, 11/10/1951, p. 1

343 "Saíram os gangsters, ficou a Assembléia”. Tribuna da Imprensa, Rio de Janeiro, 10/10/1951, p. 1 e 10.

${ }^{344}$ Ibidem.

${ }^{345}$ Ibidem.

346 "Vitória da liberdade”. Tribuna da Imprensa, Rio de Janeiro, 10/10/1951, p. 4.
} 
um após o outro. Embora usem vestimentas diferentes, todos tem o mesmo rosto - o de Perón. Além de remeter à ideia de uma conspiração, a charge transmite implicitamente a mensagem de que os que se retiraram não pensavam por si próprios, mas estavam ali como avatares do governante da Casa Rosada.

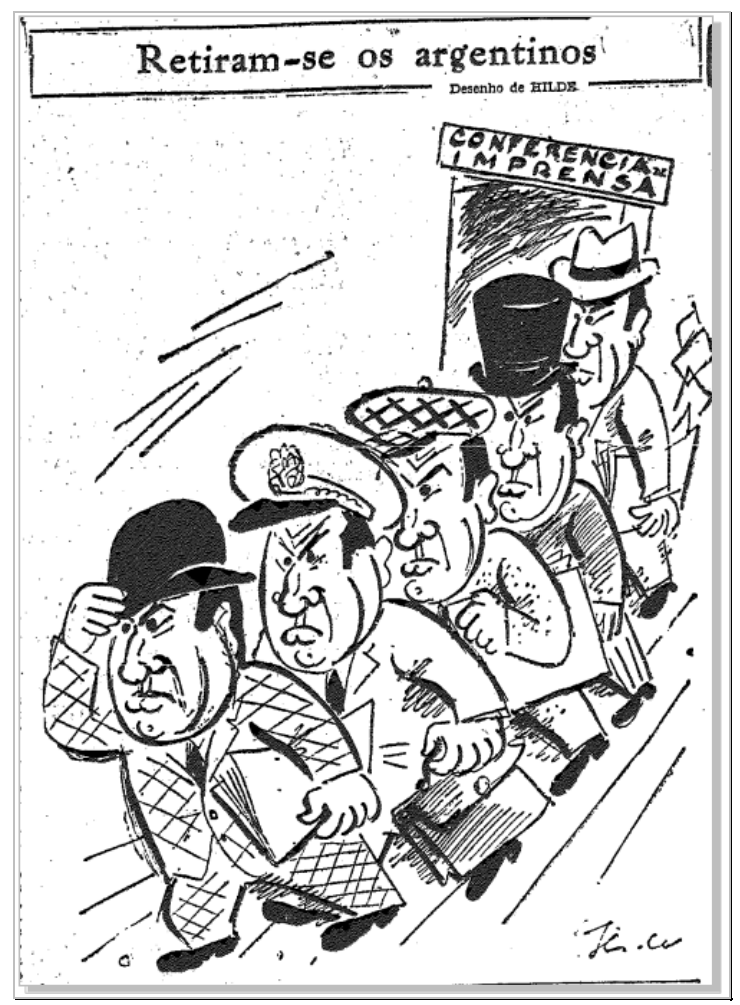

Figura 5 - HILDE, Tribuna da Imprensa, 10/10/1951, p. 4

Dias depois, foram publicadas notícias a respeito da criação pelos dissidentes da assembleia de Montevidéu de uma associação, a União Latino-Americana de Imprensa, que seria fundada em um congresso a ser realizado brevemente em Buenos Aires. Para Lacerda, "o objetivo desse bloco é considerar a liberdade de imprensa assunto político interno de cada país, livrando assim Perón das denúncias repetidas que chegam à Associação Interamericana de Imprensa" ${ }^{347}$ Não foram encontradas notícias posteriores a respeito de tal entidade.

\footnotetext{
347 "Saíram os gangsters, ficou a Assembléia". Tribuna da Imprensa, Rio de Janeiro, 10/10/1951, p. 1 e
} 10 . 


\subsection{As perseguições aos opositores}

No Brasil, crônicas e reportagens sobre o autoritarismo de Perón continuaram constantes ao longo do seu segundo e inconcluso mandato (1951-1955), especialmente em $O$ Cruzeiro. Em 1952, Theóphilo de Andrade apontou a existência de uma "ditadura disfarçada". Em suas palavras, "o Congresso, com uma maioria conseguida por demagogia ou fraude, os tribunais, aterrorizados pelo medo do executivo, e a imprensa arrolhada pela polícia, servem apenas para dar aparência legal a um governo de força”. Ele apontou a censura e as terríveis torturas contra opositores como sinais de que, acompanhada de uma crise econômica, "a ditadura Perón está se enfraquecendo". Como se tornara comum no período, os método da polícia peronista foram associados aos da Gestapo nazista. ${ }^{348}$

Poucas semanas após a morte de Evita, David Nasser deu início a uma série de cinco reportagens que denunciavam as torturas praticadas pela "Seção Especial" de Perón. Possivelmente, tratava-se de uma reação à cobertura positiva da imprensa proporcionada ao viúvo pelo luto. O jornalista viajou até a "hospitaleira, democrática e corajosa nação uruguaia" e encontrou um grupo de exilados em Montevidéu. Dentre eles Gainza Paz, o ex-proprietário de La Prensa que foi apontado como "a coluna mestra de toda oposição à ditadura peronista". ${ }^{349}$ Esses "heroicos argentinos" foram descritos como homens que "cumprem um dever patriótico e de consciência, defendendo os direitos humanos, o patrimônio e o acervo da gloriosa herança argentina, conspurcada por Perón e seu bando". ${ }^{350}$ Novamente, a violência contra a oposição foi apontada como sinal da iminente derrocada do regime.

Em "Perón denunciado às Nações Unidas", Nasser apresentou acusações que embasaram uma queixa à ONU. A maior parte delas partia do médico Alberto Caride, que fora forçado a socorrer vítimas submetidas ao suplício em sessões chefiadas pelo chefe de polícia Cipriano Lombilla. Caride narrou diversos tipos de tortura de forma bastante detalhada, especialmente as sessões de choque que faziam uso da chamada "picana elétrica". O médico descreveu os torturadores como humanos sem nenhum sinal

\footnotetext{
348 ANDRADE, Theophilo de. "Perón e os métodos de tortura de sua 'Gestapo"” In O Cruzeiro, Rio de Janeiro, 7/06/1952, p. 45.

349 NASSER, David e KEFFEL, Ed. "Pimenta nos olhos dos outros - O suplício das telefonistas" In $O$ Cruzeiro, Rio de Janeiro, 18/10/1952.

${ }^{350}$ NASSER, David e KEFFEL, Ed. "Perón denunciado às Nações Unidas" In O Cruzeiro, Rio de Janeiro, 13/9/1952.
} 
de piedade, dominados pelo sadismo e pela loucura, e o peronismo como "reencarnação do espírito do mal". Nasser acrescentou:

\begin{abstract}
Agora, o Dr. Caride, médico argentino desterrado por Perón, revela aos senhores da Organização das Nações Unidas a outra face do tirano sorridente. O Perón que não ri: que mata. O ditador que não chora; que tortura homens, mulheres, velhos e indefesos. O general que não comanda outra batalha que não seja a da lenta, implacável e evidente desintegração de um povo.

Não se trata, vejam bem, de um povo selvagem, semicivilizado, um agrupamento de bárbaros, uma nação de índios em choque. Juan Domingo Perón conseguiu, em poucos anos de governo, transformar a mais rica nação de após-guerra [...] numa nação sem trigo, sem carne, sem democracia e sem o mais leve e remoto vestígio de liberdade de pensamento e de palavra. ${ }^{351}$
\end{abstract}

Como se pode observar, o peronismo foi lido, uma vez mais, sob a ótica do dualismo civilização e barbárie. Em outra reportagem, o médico argentino narrou o caso do estudante universitário comunista Ernesto Mario Bravo, preso por policiais sem identificação e sem mandado judicial. Submetido a terríveis flagelos, ele acabou sendo libertado após pressões políticas em um episódio que teve grande repercussão. ${ }^{352}$ Também foram destacadas as detenções provisórias de trabalhadores da telefonia que resistiram à intervenção da CGT em seu sindicato. Algumas mulheres, inclusive uma grávida, teriam sido barbaramente martirizadas nos porões das delegacias e, em seguida, sumariamente demitidas. "Essas mulheres trabalhadoras e inocentes receberam o seu quinhão do justicialismo do governo de descamisados", comentou Nasser. ${ }^{353}$ Notando a contradição entre um regime que se colocava como favorável ao trabalhadores, mas que prendia e torturava aqueles que ousavam discordar, o jornalista criticou:

[...] os operários já sabem que todo e qualquer movimento justo de reivindicação será esmagado brutalmente pela polícia, que soltará sobre eles os mastins da Seção Especial. Os cães ferozes atacarão sem pena. Os monstros utilizarão métodos de tortura avançada, como a picana elétrica, que não deixa marcas - esse mesmo processo que outrora, na Argentina livre e democrática, só era usado para marcar as reses na rampa dos matadouros. ${ }^{354}$

A intensificação do autoritarismo nos anos seguintes não escapou às páginas de O Cruzeiro. Reportagens com denúncias sobre corrupção, pressões sobre a imprensa, processos e prisões de parlamentares opositores foram frequentes na longa agonia do

\footnotetext{
351 NASSER, David e KEFFEL, Ed. "Perón denunciado às Nações Unidas" In O Cruzeiro, Rio de Janeiro, 13/9/1952.

${ }^{352}$ CARIDE, Alberto. “O martírio de Mário Bravo” In O Cruzeiro, Rio de Janeiro, 27/09/1952.

353 NASSER, David e KEFFEL, Ed. "Pimenta nos olhos dos outros - O suplício das telefonistas" In $O$ Cruzeiro, Rio de Janeiro, 18/10/1952.

${ }^{354}$ Idem.
} 
regime. Em 1953, por exemplo, os repórteres Yedo Mendonça e Jorge Audi estiveram em Buenos Aires após a descoberta de um complô contra o governo. Descreveram a capital como um "inferno policial" e denunciaram

[...] a existência de 40 mil policiais em permanente atividade nas ruas da cidade, prendendo a torto e a direito, à menor desconfiança, dominados pela psicose da "agressão ao Governo". [...] Tortura, desmoralização, fome, sede, até que o infeliz confesse um crime que, em muitos casos, não foi cometido. $^{355}$

Em outra reportagem da dupla, intitulada "Enquanto Perón não cai... o terror domina Buenos Aires”, voltaram a usar termos fortes para definir a situação do país. Em suas palavras:

\begin{abstract}
O argentino é hoje, sem dúvida, um povo amargurado - apesar do golpe espetacular da rebaixa de preços de 30 por cento; dominado pelo terror, tendo sempre presente a fundamental importância do verbo denunciar. [...] Ninguém confia em ninguém. É este o clima que hoje se vive em Buenos Aires - com Perón dominando amplamente a situação, e a oposição completamente desarticulada, a ponto de não poder se locomover no sentido de retirar do país os conspiradores que ainda não foram detidos [...]. ${ }^{356}$
\end{abstract}

O colunista Theóphilo Andrade definiu o ambiente como de "terror revolucionário". Embora Perón parecesse cada vez mais forte, acreditava que a revolução justicialista, tal qual o deus romano Saturno, acabaria por devorar seus próprios filhos. ${ }^{357}$ Nesse mesmo tom, David Nasser explorou amplamente a história de uma menina de quatro anos que fora deportada sozinha da Argentina para o Brasil porque seu pai, boliviano que aqui vivia, havia escrito artigos contrários ao regime. ${ }^{358}$ De acordo com o jornalista, o "Napoleão criollo da Casa Rosada" seria o responsável pelo forte clima de desconfiança que reinava na Argentina e que estaria culminando em uma verdadeira "gestapo doméstica". Chamado em certa ocasião de "Condottieri dos pampas" 359 , Perón seria o principal culpado por "um grande povo [que] vive esmagado, de cabeça baixa, espinhal dorsal curvada, num servilismo permanente, estátua da derrota e da servidão". ${ }^{360}$ Nasser escreveu:

\footnotetext{
${ }^{355}$ MENDONÇA, Yedo e AUDI, Jorge. "Perón Contra Evita" In O Cruzeiro, Rio de Janeiro, 13/6/1953.

${ }^{356}$ MENDONÇA, Yedo e AUDI, Jorge. "Enquanto Perón não cai... o terror domina Buenos Aires" In $O$ Cruzeiro, Rio de Janeiro, 18/7/1953.

${ }^{357}$ ANDRADE, Theophilo. “A Argentina sob o terror” In O Cruzeiro, Rio de Janeiro, 20/6/1953.

${ }^{358}$ NASSER, David. "Menina de 4 anos expulsa por Perón" In O Cruzeiro, Rio de Janeiro, 5/9/1953.

359 FERREIRA, Jorge e PINTO, José. "Perón invade o Paraguai" In O Cruzeiro, Rio de Janeiro, 27/11/1954.

${ }^{360}$ NASSER, David. "Argentina, república do medo - A mulher que fugiu do inferno" In O Cruzeiro, Rio de Janeiro, 10/10/1953.
} 
[...] O povo argentino vive em silêncio os seus mais torturantes dias. Aquele orgulho, aquela altivez, aquele aprumo - tudo isto desapareceu de Buenos Aires, uma pobre cidade sem carne, sem pão e sem dignidade. Já não há reação nas ruas ou nos lares. Ninguém comenta. Ninguém fala. Apenas lê os editos e silenciosamente vai passando o pobre e desgraçado povo da grande cidade latino-americana. Restrições e mais restrições. "Perón cumple". Cumpre as suas ameaças, mas as suas promessas ele as esquece.

$\mathrm{Na}$ intimidade dos lares, o medo é igual. Os maridos receiam abrir as comportas dos seus corações às esposas e já não confiam nos seus filhos. As denúncias levam à cadeia e à sala de torturas, e, em Buenos Aires, as delações de pais e filhos, irmãos e parentes, são banais e constantes, tal qual em todos os regimes de terror e opressão. ${ }^{361}$

Pouco antes da queda de Perón, a revista cobriu a passagem de Ángel Borlenghi pelo Uruguai em direção ao exílio. O ex-sindicalista e ex-ministro do Interior da Argentina era apontado como um dos principais responsáveis pelas torturas e outras violações de direitos humanos no porões do regime. Vaiado por exilados em solo uruguaio, Borlenghi foi tido como um homem sinistro e chamado pela revista de "Béria argentino" 362 e "Himmler peronista". Os periodistas não deixaram de notar a ironia que cercava aquela situação, na qual uma multidão aguardava a oportunidade de hostilizar o carrasco justicialista em um aeroporto de nome Carrasco, localizado a apenas 20 quilômetros de Montevidéu. ${ }^{363}$

A ênfase nos aspectos antidemocráticos do regime justicialista também esteve presente em diversas charges. Nelas, o presidente argentino aparece sempre com um semblante fechado, em oposição às fotografias divulgadas oficialmente que 0 mostravam com um belo sorriso. A acusação de filiação nazi-fascista também pode ser observada, como nas figuras 6 e 7. Na primeira, Perón faz a saudação nazista a um cachorro, que supostamente teria recebido de presente. Vale destacar que excepcionalmente esse desenho foi assinado por J.T., artista que não conseguimos identificar.

\footnotetext{
${ }^{361}$ Ibidem.

${ }^{362}$ Lavrenti Béria (1899-1953) foi chefe da temida polícia secreta soviética (NKVD) durante o governo stalinista, especialmente entre 1938 e 1953. Descrito como um homem sombrio, foi responsabilizado por crimes de guerra e pela prisão e assassinato de milhares de pessoas tidas como "inimigos do povo". Após expurgos políticos, muitas delas foram enviadas para os campos de trabalho forçados soviéticos (gulags). ${ }^{363}$ SILVA, Arlindo e DAMM, Flavio. "Borlengui - o carrasco peronista" In O Cruzeiro, Rio de Janeiro, 23/07/1955.
} 


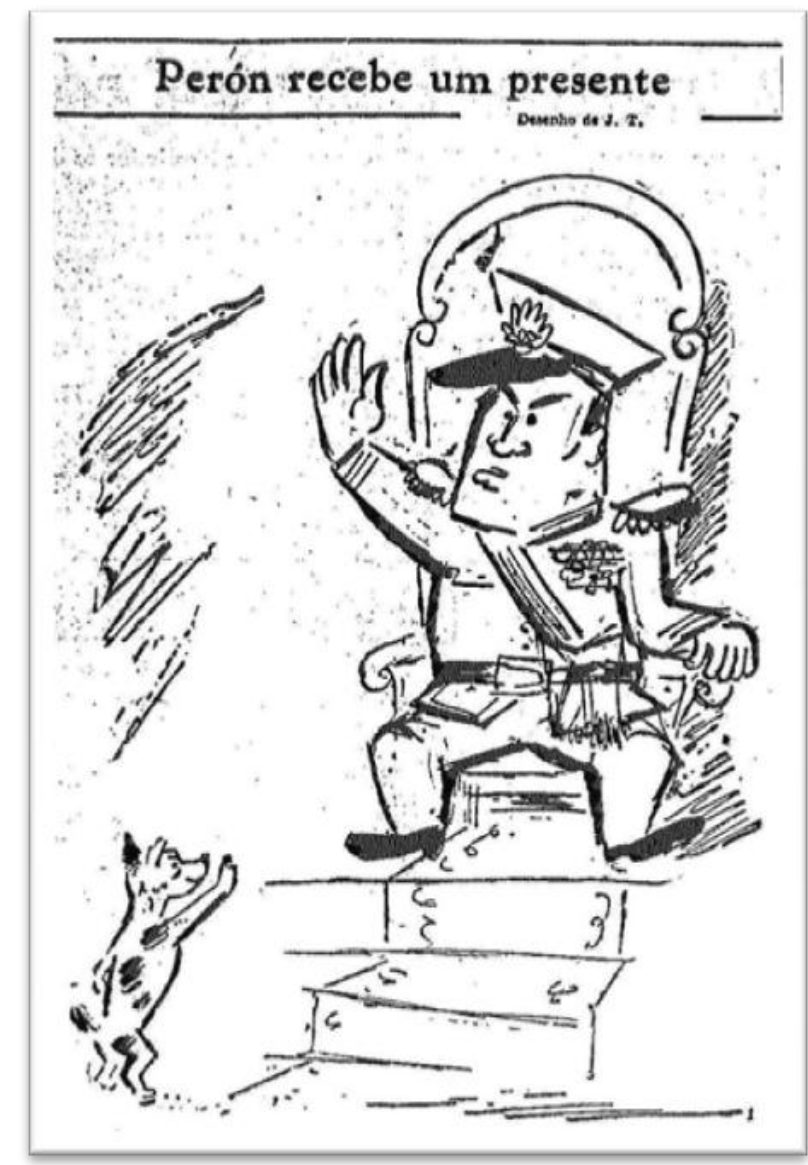

Figura 6 - J.T., Tribuna da Imprensa, 23/01/1951, p. 4.

Hilde produziu uma charge com uma crítica ainda mais explícita nesse sentido (figura 7). Como um fantasma, o líder do Terceiro Reich emana dos livros queimados e cumprimenta o presidente argentino ("Heil"), que desta vez é representado mais baixo e gordinho, mas igualmente com cara amarrada. A imagem provavelmente faz referência à repressão à cultura e à imprensa que estavam ocorrendo na Argentina naquele momento. A artista procurou estabelecer um paralelo entre tal situação e os espetáculos públicos de queimas de livros ocorridos Alemanha nazista em 1933. Ao lado dos desenhos, publicou-se um editorial de Lacerda em que Perón era novamente colocado como discípulo aperfeiçoado de Vargas. Destacou-se também as características autoritárias do seu governo e sua admiração, junto com outros membros do GOU, pelos países do Eixo durante a Segunda Guerra Mundial. 


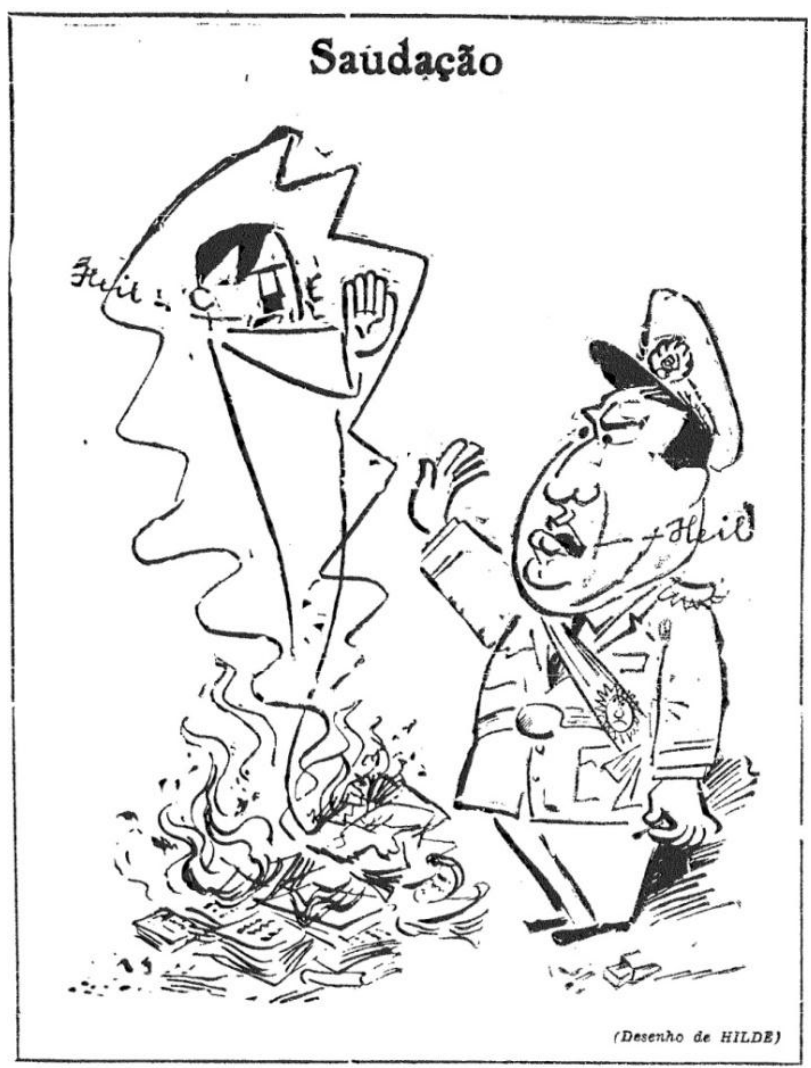

Figura 7 - HILDE. Tribuna da Imprensa, Rio de Janeiro, 17/4/1953, p. 4

\subsection{A bomba atômica peronista}

Além da expropriação de La Prensa, outro importante acontecimento nos primeiros meses de 1951 ajudou a ampliar temporariamente o apoio interno ao regime e a desconfiança dos outros países. Em 24 de março, Perón anunciou com entusiasmo que, liderados por um alemão chamado Ronald Richter, cientistas argentinos haviam conseguido produzir "reações termonucleares sob condições de controle em escala técnica". O experimento teria ocorrido em laboratórios secretos localizados na ilha Huemul, em San Carlos de Bariloche. O presidente aduziu que a energia atômica seria utilizada exclusivamente para fins industriais, mas Richter assegurou que o país já conhecia o segredo da bomba de hidrogênio e poderia produzi-la, caso fosse necessário.

$\mathrm{O}$ anúncio teve enorme impacto entre os apoiadores do regime, algo valioso em um momento no qual as eleições presidenciais se aproximavam. Meses depois, Perón garantiu que haveria usinas atômicas em funcionamento no país em dois anos, produzindo energia a custos muito baixos. 
No entanto, os jornais brasileiros e as agências de notícias internacionais receberam a notícia com um misto de ceticismo e apreensão. Afinal, ninguém no mundo da física sabia quem era o cientista alemão que emigrara para Buenos Aires após a guerra e que alegava ter inventado um método revolucionário de produção de energia atômica bastante diferente daqueles que vinham trabalhando as superpotências. As solicitações de detalhes técnicos foram convenientemente negadas sob alegação de segredo militar.

Após diversos físicos no Brasil e no mundo demonstrarem sua desconfiança em torno da descoberta, Lacerda classificou-a como um "ardil de feira" e um "truque de matinê". Seria a "bomba de um governo bambo". ${ }^{364}$ Dias depois, seu jornal publicou o boato, que acabou por não se confirmar, de que Richter fora desmascarado como charlatão e preso por ludibriar Perón. ${ }^{365}$ Uma nota não assinada em Tribuna da Imprensa chegou a achacar explicitamente o presidente argentino, assegurando que este fizera papel de "otário" ao dar ao mundo "um motivo para rir [...], em meio das apreensões mais graves. ${ }^{366}$

Apenas três dias após o anúncio, Hilde Weber também ridicularizou a revelação (figura 8). Na charge, Perón aparece vestido como um garoto, em roupas curtas e com estilingue no bolso. Como um menino arteiro, ele teria aprontado mais uma de suas traquinagens. Nas mãos, carrega uma pequena bomba utilizada nos festejos de São João, numa sinalização de que sua pretensa arma atômica não passaria de embuste. Longe de uma expressão marota, seu rosto transmite a tradicional expressão grave de outros desenhos.

\footnotetext{
${ }^{364}$ LACERDA, Carlos. "A bomba do governo bambo" In Tribuna da Imprensa, Rio de Janeiro, 27 de março de 1951, p. 4.

365 "Perón prendeu Richter, o charlatão atômico" In Tribuna da Imprensa, Rio de Janeiro, 23/5/1951, p. 1

366 “O Otário” In Tribuna da Imprensa, Rio de Janeiro, 23/5/1951, p. 1
} 


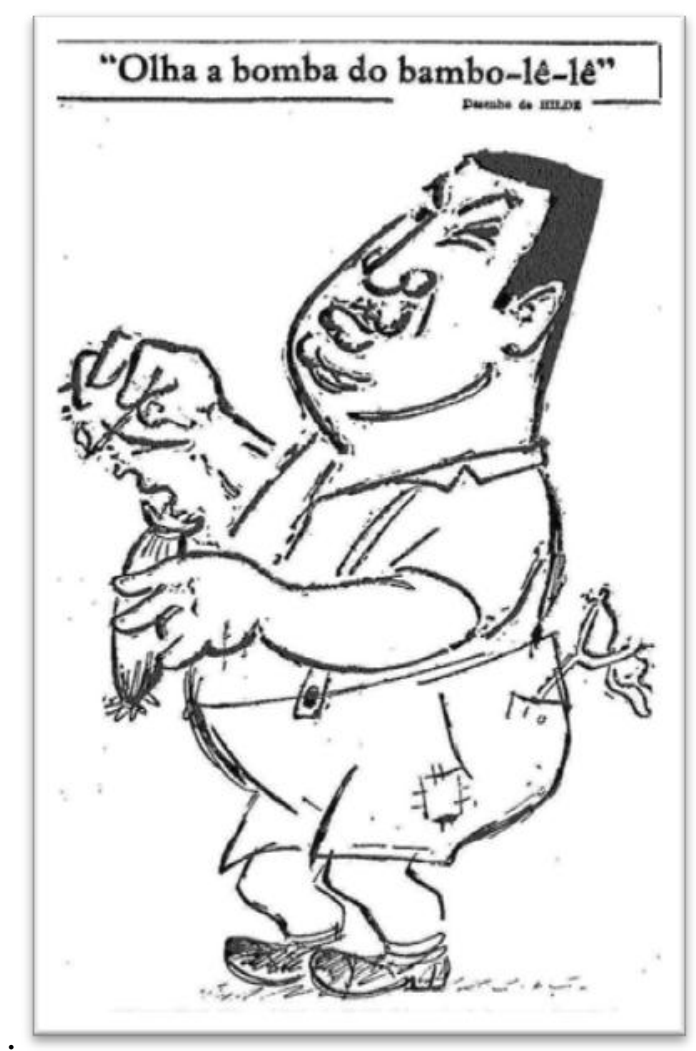

Figura 8 - HILDE. Tribuna da Imprensa, 27/03/1951, p. 4.

O episódio serviu como mote para várias charges que ridicularizaram Perón como um espertalhão, responsável por ações impensadas que acabaram mal. As duas representações (espertalhão e estúpido) tendiam a se complementar, pois na visão da artista Hilde Weber o líder argentino, na ânsia de conseguir vantagens ilicitamente, acabava por se atrapalhar.

Em maio, foi veiculado outro desenho bastante irônico (figura 9). Com ar severo e usando o tradicional quepe e a faixa presidencial, o presidente argentino faz as vezes de camponês e cuida de seus "cogumelos atômicos". Estes não passariam de cogumelos tradicionais. A imagem faz referência às nuvens em forma de cogumelo que aparecem após as explosões atômicas. 


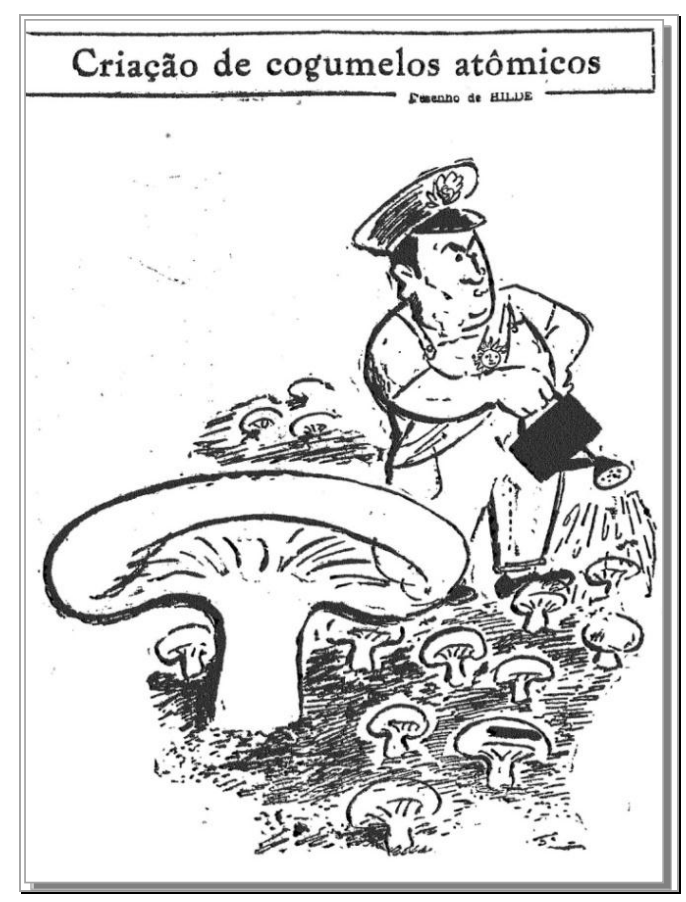

Figura 9 - HILDE. Tribuna da Imprensa, 28/5/1951, p. 4.

Apesar de certo descrédito, as alegações do governo argentino foram acompanhadas com atenção pelos cronistas que viram no anúncio mais um sinal inequívoco do imperialismo justicialista. Para Franklin de Oliveira, apesar do "gigantesco e frustrado golpe publicitário" justicialista, o governo brasileiro deveria pensar em sua defesa e adotar a postura daquele que, nas suas palavras, "seguro morreu de velho". Segundo ele,

O episódio argentino obriga o governo brasileiro a considerar com maior gravidade o problema nacional das investigações atômicas. É obrigação não só de atender a cientistas, a eruditos, a homens de cultura, mas dever essencial de segurança e sobrevivência do Brasil, como Estado soberano e Nação íntegra. [...] Procuremos tornar-nos, real e efetivamente, em nação atômica. Quando até a Índia persegue estes objetivos, por que o Brasil não poderá fazê-lo? $?^{367}$

Para Rachel de Queiróz, a bomba atômica argentina, "imaginária ou real," garantia a Perón uma forma de intimidação aos inimigos externos. De acordo com ela, "a bomba atômica na mão do general seria como uma bazooka na mão de Virgulino: a segurança da impunidade". ${ }^{368}$ Lacerda foi no mesmo sentido, o de que era imperativo

367 OLIVEIRA, Franklin de. "Golpe e ameaça argentinos, dever brasileiro". Coluna Sete Dias In: $O$ Cruzeiro, Rio de Janeiro, 7 de abril de 1951, p. 7.

${ }^{368}$ QUEIROZ, Rachel de. "O drama de "La prensa"”' In O Cruzeiro, Rio de Janeiro, 21/04/1951, p. 130. 
antecipar a agressão platina que, na sua perspectiva, estava relacionada à ação dos comunistas. Ele escreveu:

\begin{abstract}
Mas suponhamos que ela [a descoberta] seja verdadeira [...]. Neste caso, tratemos de ajudar o povo argentino a derrubar Perón, antes que ele obrigue a Argentina a conflagrar a América.

Assim, pois, de duas, uma. Ou Perón mente, e neste caso é perigoso, porque nada há mais perigoso do que um governante que mente ao povo para adquirir mais poder, ou Perón diz a verdade, e neste caso devemos pedir que se reúna uma conferência interamericana para a defesa conjunta da América contra a ameaça do general Perón.

Não tem sentido a defesa do continente contra a ameaça de uma agressão russa, se paralelamente não se promover a defesa do continente contra a agressão que se prepara aqui dentro mesmo.

E que é, no fundo, a mesma agressão. Se tiverem dúvidas, vejam a conduta dos diferentes partidos comunistas em relação ao general Perón. Eles são aliados. Eles se completam.

Ambos são agressores. Ambos empregam o "bluff" como arma política. ${ }^{369}$
\end{abstract}

Talvez para abrandar a repercussão profundamente negativa no Brasil, Perón aceitou um convite inusitado: conceder entrevista a um jornalista da revista $O$ Cruzeiro, então proibida no país. Na ocasião, o presidente argentino reafirmou ao repórter Flávio Damm que não posuía a bomba de hidrogênio e que as experiências tinham intuito puramente pacifista. Reclamou também da imagem equivocada que as pesquisas de Richter tinham produzido no exterior. O texto da reportagem, porém, foi-lhe amplamente desfavorável e insistiu no autoritarismo no regime e na ideia de que Perón preparava uma "sorrateira aventura imperialista" na região. ${ }^{370}$

Malgrado as inúmeras objeções e desconfianças vindas do exterior, o presidente platino seguiu com seu sonho de obter enegria atômica barata e fácil por mais um ano e meio. Apenas no final de 1952, chegou-se a conclusão de que as pesquisas de Richter realmente não passavam de um embuste, uma grande e caríssima fantasia que havia seduzido Perón. De acordo com o jornalista Stefan Baciu, o projeto Huemul consumira um bilhão de pesos argentinos aos cofres públicos. ${ }^{371} \mathrm{O}$ enigmático Richter, que sequer era alemão e tampouco especialista em física nuclear, foi oficialmente demitido, o projeto paralisado e o assunto cuidadosamente jogado para escanteio na propaganda

\footnotetext{
${ }^{369}$ LACERDA, Carlos. "A bomba do governo bambo" In Tribuna da Imprensa, Rio de Janeiro, 27 de março de 1951, p. 4.

${ }^{370}$ DAMM, Flavio. "Perón não tem a bomba atômica” In: O Cruzeiro, Rio de Janeiro, 22/9/1951

371 BACIU, Stefan. "Bolha de sabão - a bomba atômica de Perón" In Tribuna da Imprensa, Rio de Janeiro, 4/10/1954, p. 3 do caderno 3.
} 
peronista. Os opositores no Brasil, porém, faziam questão de lembrar o episódio. David Nasser, por exemplo, alcunhou Perón de "genial criador de bombas cômicas". 372

Outro episódio ocorrido em 1951 serviu de motivo para mais chacotas por parte do jornal (figura 10). Na comemoração do "Día de la Lealtad" peronista (17 de outubro), uma pequena nota da United Press informou que o Observatório Astronômico de La Plata descobrira um novo planeta e o batizara com o nome de "justicialista". De acordo com declarações do reitor da universidade, a homenagem "significa a identidade da corporação universitária com os ideais do povo argentino em suas festas do corrente mês de outubro, consagrado à maior das virtudes humanas: a lealdade." ${ }^{373}$

No dia posterior à manchete, Hilde satirizou o presidente argentino colocando sua cabeça como um planeta ao redor do qual girava um anel. Indiretamente, criticavase a megalomania do regime e atitude despropositada de atribuir o nome de um político tido por demagogo a uma descoberta tão importante. Em outra chave de leitura, pode-se pensar que a cabeça de Perón continha pensamentos tão exóticos que só podia ser pensada como um mundo à parte. Seus pensamentos seriam tão estranhos que pareciam originários de outra realidade.

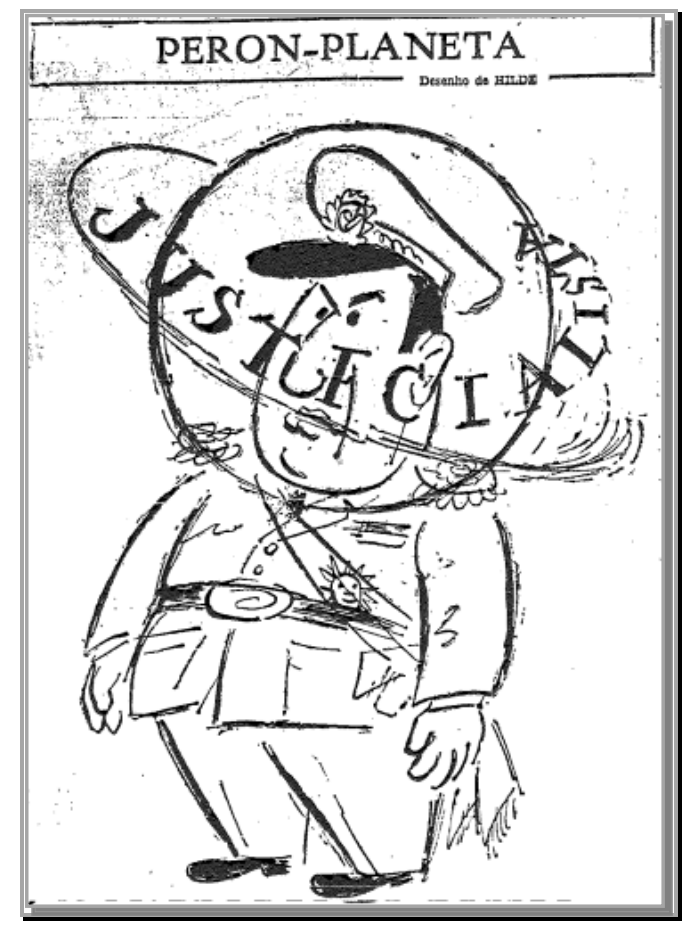

Figura 10 - Tribuna da Imprensa, 18/10/1951, p. 4.

\footnotetext{
372 NASSER, David e KEFFEL, Ed. "Perón denunciado às Nações Unidas" In O Cruzeiro, Rio de Janeiro, 13/9/1952

373 “Um planeta para Perón” In Tribuna da Imprensa, Rio de Janeiro, 17/10/1951, p. 1.
} 
A propósito, vale lembrar que, de acordo com Maria Helena Capelato, as universidades argentinas sofreram dura intervenção durante o governo peronista. A partir da Reforma Universitária de 1947, os reitores passaram a ser indicados pelo Poder Executivo, a representatividade estudantil foi drasticamente reduzida e ampliou-se ainda mais a penetração de setores católicos mais radicais na direção dessas instituições. Além disso, elas foram inundadas pela propaganda oficial peronista. A repressão que se abateu sobre os campi levou muitos estudantes ao cárcere e centenas de professores à demissão. Por outro lado, foram realizadas melhorias no campo da infraestrutura e estabelecida a gratuidade, o que facilitou o acesso aos cursos superiores pelos setores populares. Tais medidas, no entanto, não conseguiram impedir que as universidades se configurassem como um dos principais focos de resistência ao autoritarismo do regime. $^{374}$

\subsection{O povo esclarecido contra a massa fanática}

Como explicar a longa duração e a inegável popularidade do peronismo com uma parte da população argentina? Afinal, parecia evidente que o regime não se mantinha apenas pela força. Vários jornais liberais-conservadores classificaram reiteradamente os apoiadores do justicialismo como uma "massa fanática e bárbara"375, seduzida por uma forte propaganda e que agia sob impulsos primitivos. Desse ponto de vista, caberia aos "grupos mais esclarecidos" lutar pelo resgate da democracia e dos valores da civilização que teriam sido subvertidos.

Como se vê, trata-se de um discurso semelhante àquele que a própria UDN utilizava na política nacional em alguns momentos. Udenistas, de modo geral, difundiam a autoimagem de superioridade e excelência de um grupo que se via como elite econômica e cultural. De acordo com Maria Victoria de Mesquita Benevides, em termos de prática política isso se traduziu na "identificação de reivindicações sociais [...] com a desordem, 'o caos', e [em] um solene desprezo pelo povo - 'as massas' refletido na permanente revolta com a derrota [udenista] nas urnas, considerada 'fruto da ignorância popular","376

Esse elitismo do partido, carregado de um "solene desprezo pelas massas", é facilmente perceptível nas fontes sobre a experiência política peronista. Termos como

\footnotetext{
${ }^{374}$ CAPELATO, 2008, op. cit., p. 130-4.

375 "Perón desarma o Exército e arma a CGT" In Tribuna da imprensa, Rio de Janeiro, 16/09/1955, p. 6

${ }^{376}$ BENEVIDES, op. cit., p. 253.
} 
horda ${ }^{377}$, rale ris $^{374}$ turba $^{379}$, vândalos ${ }^{380} \mathrm{e}$, principalmente, fanáticos ${ }^{381}$ foram muito utilizados para descrever os apoiadores do regime e mostram uma tenaz demofobia. Na legenda de uma foto com manifestantes, por exemplo, pode-se notar a explícita estratégia de mostrar que entre estes reinava a ignorância:

"VIVA PERÓN! ABAIXO BRADEN!" - O povo grita o nome do exembaixador americano, mas se perguntarmos a 50\% quem é Braden, pensarão que é marca de refresco. A velha técnica Braden-Griffins não surte mais efeito. ${ }^{382}$

De modo geral, difundiu-se a representação de que uma minoria manobrava inescrupulosamente as "massas fascinadas pela propaganda e dementadas pelo incitamento à guerra de classes e ao ressentimento". ${ }^{383}$ Para Theóphilo de Andrade, essa massa amorfa e irracional seria guiada pelos instintos mais baixos e possuiria "prazer infinito em incendiar e saquear". Em suas palavras:

Perón se ativa, efetivamente, à mais desbragada violência, mas a violência, em seu caso, o fortalece, em vez de enfraquecê-lo. É que a sua atuação está a tomar um caráter revolucionário, de luta contra as classes aristocráticas e conservadores, e de apelo aos mais baixos instintos da plebe. [...]. E quando as suas medidas não deram os frutos imaginados, seja pela incompetência dos seus conselheiros ou pela corrupção dos que o cercam, buscou bodes expiatórios para os males públicos. Foi além: confiou à própria plebe a execução dos seus desígnios, como o que, de uma cajadada, mata dois coelhos: liquida os seus inimigos reais ou potenciais e satisfaz os complexos de inferioridade da plebe. Esta, como aconteceu na Revolução Francesa, ou como se verificou, ainda em 1948, no incêndio de Bogotá, tem um prazer infinito em incendiar e saquear. Fá-lo por conta própria, quando incendiada pelos demagogos. E fá-lo com maior prazer e requinte, quando a polícia a incentiva e lhe assegura impunidade. ${ }^{384}$

Em uma leitura um pouco diferente, Rachel de Queiroz discorreu sobre a "daninha raça de ditadores" sul-americanos. Apontou, sobretudo, sua "falta de classe" e esperteza ao aproveitar "da descrença, do desânimo e do desinteresse das elites”. Perón,

${ }^{377}$ ANDRADE, Theophilo de. "O excomungado" In O Cruzeiro, Rio de Janeiro, 9/7/1955.

${ }^{378}$ BACIU, Stefan. "Perón: ascensão e queda de um tirano" In Tribuna da Imprensa, Rio de Janeiro, 21/9/1955, p. 8.

379 "Condenados à forca pelo jornal de Perón três juízes brasileiros" In Tribuna da Imprensa, Rio de Janeiro, 16/11/1950, p. 1 e 10.

${ }^{380}$ CARDOSO, Lycurgo e RONEK, Antônio."A Revolta" In O Cruzeiro, Rio de Janeiro, 9/7/1955.

381 CARLOS, Newton. "Apoteose de liberdade na capital argentina" In Tribuna da Imprensa, Rio de Janeiro, 24-25/9/1955, p. 4.

382 NASSER, David e WANDERLEY, Indalecio. "Perón balança, mas não cai” In O Cruzeiro, Rio de Janeiro, 20 de setembro de 1951.

${ }^{383}$ LACERDA, Carlos. "Aleluia argentina e paixão brasileira" In Tribuna da Imprensa, Rio de Janeiro, 20/9/1955, p. 4.

${ }^{384}$ ANDRADE, Theophilo. "A Argentina sob o terror” In O Cruzeiro, Rio de Janeiro, 20/6/1953. 
em particular, foi classificado como um "coronel balofo" e "medíocre", que teria sido ajudado por Evita, uma "pequena igualmente ambiciosa, igualmente sem escrúpulos e intelectualmente mais dotada do que ele". ${ }^{385}$ A questão do ressentimento também foi destacada:

[...] a mola que os anima [ditadores sul-americanos] é o ressentimento - e quanto pode o ressentimento atuante neste mundo povoado de otários! O ressentimento desenvolve neles essa estranha e contraditória espécie de megalomania: acreditam e obrigam os outros a acreditar na própria estrela. Aliás, muitas vezes nem essa crença eles têm: simulam apenas. Sabem muito bem que são filhos das circunstâncias, do geral abaixamento de um povo, da descrença, do desânimo, do desinteresse das elites. E quando falo nas elites, não me refiro aos grandes nomes da aristocracia ou da finança, mas aos mais dotados, aos mais capazes de exercer o poder e orientar a comunidade. Num oleoso mar de desinteresse, eles flutuam - em geral como um cadáver flutua, inflado com os próprios gases de decomposição. ${ }^{386}$

Em outra crônica, Theóphilo de Andrade voltou a associar o justicialismo aos instintos animais, caracterizando seu líder como um ser primário e violento, desprovido de qualquer moral. Na sua ótica, a brutalidade do guia permitia que seus comandados se deixassem conduzir mansamente. Ele escreveu:

JUAN Domingo Perón é um lugar-comum da história. Tem seguido a rota de todos os maus ditadores. Homens enérgicos e com um profundo sentido animal, estão mais aproximados da escala puramente zoológica do que do "homo sapiens". E esse é o segredo do seu êxito, pois o homem não é tão nobre quanto queremos fazê-lo. Alguns milhares de séculos nos separam dos primatas. Mas a cultura acumulada, durante essa longa peregrinação de nossa espécie sobre a terra, nos forneceu apenas uma ligeira camada de vida racional. Por debaixo dela, continuamos de carne e osso, como os outros animais. E desde que se arranhe o "homo sapiens", aparece o troglodita. Através das idades, forjaram-se os freios da moral e da Polícia. Quando estes, porém, desaparecem, surge o primata em toda a sua brutalidade. E aqui encontramos a distinção entre os bons e os maus ditadores. É que estes não têm moral. E eles são a própria Polícia. Para suprema desgraça, na marcha da história, atuam sobre uma espécie zoológica de caráter gregário, como é a humanidade. E o animal gregário se deixa conduzir com tanto mais docilidade quanto mais bruto é o seu guia. Este, graças, exatamente, ao seu espírito animal, espicaça os instintos da horda, criando-lhes inimigos a combater, uns após outros. Desde que tenha o poder político, solidamente em mãos, excitam a massa contra a elite, os pobres contra os ricos, a multidão dos fracos contra os poucos fortes existentes na comunidade. E nessa marcha, têm que defrontar-se, um dia, com as forças morais que elevaram a humanidade do nível animal ao nível racional, através dos tempos. ${ }^{387}$

Essa representação de uma massa irracional, sem personalidade, guiada pelos seus instintos animais, seduzida pela propaganda e por um líder imoral, produzia, ao

\footnotetext{
${ }^{385}$ QUEIROZ, Rachel de. “Perón” In O Cruzeiro, Rio de Janeiro, 29/10/1955.

${ }^{386}$ Ibidem.

${ }^{387}$ ANDRADE, Theophilo de. "O excomungado" In O Cruzeiro, Rio de Janeiro, 9/7/1955.
} 
menos, dois efeitos. Primeiro, tirava daqueles que a compunham, principalmente os trabalhadores, a qualidade de agentes das transformações que estavam ocorrendo. Ao retratar o justicialismo como resultado da manipulação do povo, eclipsava-se que, malgrado sua propaganda bastante intensa, o peronismo foi um movimento social apoiado por parte considerável dos argentinos. Segundo, ficava subjacente a negação da luta de classes. Perón não representaria os interesses dos menos favorecidos, apenas os seus próprios. Essa perspectiva é bem mais evidente em alguns cronistas, como David Nasser, do que em outros. Para este, os conflitos políticos platinos eram essencialmente uma luta do bem contra o mal, e não um embate entres "as oligarquias" e "os descamisados", como queria a oratória justicialista.

Essa negação da questão de classe é perceptível em diversos momentos. Nas manchetes e reportagens, por exemplo, a palavra justicialismo apareceu com frequência consideravelmente menor do que sua congênere peronismo. Além disso, ela foi utilizada quase sempre entre aspas, o que denota certo desconforto ou, mesmo, rejeição à noção de que o regime argentino promovia a justiça social. A defesa dos "débeis contra os fortes", que integrava o discurso peronista, também foi reiteradamente apontada como mero pretexto demagógico. ${ }^{388}$ Ao comentar as contribuições forçadas para obras de assistência social, por exemplo, Rachel de Queiroz chegou a afirmar que se tratava de um regime que tirava "dos pobres para dar aos pobres". ${ }^{389}$

$\mathrm{Na}$ pena de outros cronistas, porém, a polarização classista veio à tona em pequenos trechos. Theóphilo de Andrade admitiu que Perón apoiou-se no proletariado porque "os partidos políticos, em dezenas de anos de governo, não souberam dar privilégios ou direitos já conquistados no resto do mundo civilizado". ${ }^{390}$ Outro repórter de O Cruzeiro, Flávio Damm, reconheceu en passant que as "desigualdades sociais [na Argentina] estão caindo". Ainda assim, afirmou que isso ocorria "não apenas pela direta interferência do peronismo, senão como uma consequência inevitável de conquistas que têm amplitude universal". 391 Essas fugazes considerações não impediram que as medidas trabalhistas fossem criticadas. Em determinado momento, a crise agropecuária

\footnotetext{
388 NASSER, David e KEFFEL, Ed. "Perón denunciado às Nações Unidas" In O Cruzeiro, Rio de Janeiro, 13/9/1952

389 QUEIROZ, Rachel de. "Evita” In O Cruzeiro, Rio de Janeiro, 16/8/1952.

${ }^{390}$ ANDRADE, Theóphilo de. “As táticas de Perón” In O Cruzeiro, Rio de Janeiro, 09/05/1953.

${ }^{391}$ DAMM, Flavio. "Perón não tem a bomba atômica" In: O Cruzeiro, Rio de Janeiro, 22/9/1951.
} 
que a Argentina atravessava foi atribuída, entre outras coisas, a uma "legislação social incompatível com o estado social do país". 392

A divisão social apareceu ainda nas descrições sobre o clima de terror que estaria predominando no país vizinho. Em uma reportagem de Arlindo Silva, ele caracterizou a Argentina como um país cindido:

\begin{abstract}
Ninguém confia em ninguém. Os pais têm medo dos filhos. Os patrões têm nos empregados, muitas vezes, inimigo e delatores. As domésticas, todas pertencentes aos sindicatos e, portanto, à CGT, são espiãs de Perón instaladas nas casas de família. Quando elas estão presentes na hora das refeições ou dos lanches, os patrões desconversam, falam de Gary Cooper, de Gene Kelly ou de corridas de cavalos. O "justicialismo" peronista conseguiu levar o pânico e o medo até o seio das família argentinas. Num hotel qualquer ninguém pode confiar num garção, na arrumadeira ou na telefonista. Os telefones argentinos só são usados para o trato de assuntos sem importância, porque as conversas mais delicadas só são travadas pessoalmente [...] uma palavra contra o regime peronista, dita em tom elevado, pode significar tempo indeterminado nas celas frias da Polícia peronista. Por isso se cochicha tanto na Argentina. E uma Nação, onde os cidadãos só falam ao pé do ouvido, não é uma Nação. É um cativeiro. É a isso que Perón reduziu a Argentina. ${ }^{393}$
\end{abstract}

De acordo com Theóphilo de Andrade, haveria na Argentina "aquilo que Rauschining chamou de oclocracia ou, mais precisa e claramente, ditadura da plebe, cesarismo das massas barbarizadas". Esta se manteria por meio da CGT, "uma pseudoconfederação de trabalhadores, confundindo na consciência rebaixada e deformada destes operários um ato de pirataria com a máscara de uma reivindicação trabalhista $[\ldots] " 394$

A propósito, a CGT foi repetidamente apontada como espécie de "tropa auxiliar do partido governante". ${ }^{395}$ Nos conflitos que culminaram com a queda de Perón, ela foi acusada de impor um "rush de obreros" em direção à Plaza de Mayo. Noticiou $O$ Cruzeiro:

Milhares de trabalhadores não quiseram atender ao chamamento, mas foram empurrados à Plaza de Mayo com revólveres nas costas. A prova disso é que mais de 4 mil tombaram, assassinados, nesse dia, e seus corpos encheram 4 quadras do Cemitério Chacarita, em Buenos Aires. ${ }^{396}$

\footnotetext{
${ }^{392}$ ANDRADE, Theophilo de. "Perón cumple” In O Cruzeiro, Rio de Janeiro, 28/06/1952, p. 53.

393 SILVA, Arlindo e DAMM, Flavio."O comediante da Plaza de Mayo" In O Cruzeiro, Rio de Janeiro, 24/9/1955.

${ }^{394}$ OLIVEIRA, Franklin. "Violência e ignomínia". Coluna Sete Dias In: O Cruzeiro, Rio de Janeiro, 17 de março de 1951, p. 7.

395 NASSER, David e KEFFEL, Ed. "Pimenta nos olhos dos outros - O suplício das telefonistas" In $O$ Cruzeiro, Rio de Janeiro, 18/10/1952.

396 LEMOS, Ubiratan; WANDERLEY, Indalécio e RONEK, Antônio. “Adeus, Perón, Bem-vindo, Lonardi” In O Cruzeiro, Rio de Janeiro, 8/10/1955.
} 
Lacerda, em especial, advertiu inúmeras vezes para o risco que representaria ao Brasil a repetição de um sindicato unificado, poderoso e que, em sua ótica, era controlado pelos comunistas. Ele chamou a CGT argentina de "gang" e afirmou que não passava de "pelegos fascistas". ${ }^{397}$ Em algumas ocasiões, denunciou que a entidade estaria fazendo a função de polícia e que o Executivo teria entregado armamentos do Exército a essa "massa fanática". ${ }^{398}$ As prisões arbitrárias feitas pela agremiação provariam, em suas palavras, o andamento de um processo de "sovietização à moda crioulla da ditadura de Perón". ${ }^{399}$ Em editorial de 1951, o jornalista carioca aduziu:

Paralelamente ao Exército e à Polícia, o sistema presidido pelo general Perón tem a sua Confederação Geral do Trabalho (CGT), que é uma falsificação trabalhista ainda maior do que a Conferência Sindical brasileira, que todos sabem não existir senão para um efeito de pilhar o dinheiro do Fundo Sindical e promover manifestações ao governo.

A CGT é um instrumento de domínio do bando que controla o Estado argentino, sob rótulo trabalhista ou - para usar a expressão do sr. Perón - "justicialista”. O Estado peronista assenta numa parte do Exército, na polícia secreta e na CGT - que desempenha o papel de representante espontâneo e sem mandato do proletariado argentino. [...] A CGT prende, a CGT condecora oficiais das forças armadas, segundo o grau de lealdade a Perón, a CGT organiza expedições punitivas. ${ }^{400}$

Naturalmente, ao destacar a intensidade da propaganda e da violência do regime acabava-se indiretamente por louvar os "heróis" que lutavam contra esse quadro. Estes eram retratados como pessoas "esclarecidas" ou "conscientes" em detrimento da massa irracional. Ao tratar, por exemplo, da tentativa de derrubada de Perón em junho de 1955, o repórter Lycurgo Cardoso explicou:

Os civis também se dividiam em esclarecidos e fanáticos, ou seja, em povo consciente, sofrendo a ausência da liberdade, e povo envenenado pelas peçonhas do justicialismo, capaz de lutar, sem saber por que, para defender o ditador que lhe prega mentiras bem arquitetadas por técnicos de propaganda política. ${ }^{401}$

Em meio à crise política que antecedeu a "Revolução Libertadora", Arlindo Silva assinou a reportagem "O comediante da Plaza de Mayo", que ia no mesmo sentido ao dividir a sociedade entre pessoas conscientes e aquelas guiadas pelos baixos instintos.

\footnotetext{
397

398 "Perón desarma o Exército e arma a CGT" In Tribuna da Imprensa, Rio de Janeiro, 16/09/1955, p. 6

399 “Terror na Argentina” In Tribuna da Imprensa, Rio de Janeiro, 15/10/1951, p. 1 e 10.

${ }^{400}$ LACERDA, Carlos. "O verdadeiro caráter do movimento peronista" In Tribuna da Imprensa, Rio de Janeiro, 23/10/1951, p. 4

${ }^{401}$ CARDOSO, Lycurgo e RONEK, Antônio."A Revolta" In O Cruzeiro, Rio de Janeiro, 9/7/1955.
} 
Ele destacou que as ameaças do discurso de Perón se destinavam à oposição, que seria formada por

[...] argentinos conscientes, que, mesmo cochichando, constituem uma opinião poderosa, apesar de silenciosa. E esses constituem 90 por cento do povo argentino. $\mathrm{O}$ ditador quis mostrar aos chefes militares que possui um exército maior que o que veste farda. É o Superexército da CGT, cujos soldados são "descamisados" ou usam macacão. É um Superexército bem armado (as armas que lhe tinham sido tomadas foram devolvidas), que se dispõe a sair à rua, em "milícias populares" para garantir a continuidade do peronismo. São 6 milhões de "obreros" dispostos a lutar e a morrer, de fuzil na mão, em defesa do Grande Chefe. ${ }^{402}$

Uma consulta aos dados demográficos da Argentina no período permite questionar o trecho e indagar a respeito de uma possível manipulação dos dados. Em 1955, o país possuía população estimada em cerca 19 milhões de pessoas, dos quais aproximadamente $15 \%$ se encontravam abaixo dos 15 anos. Assim, em se confirmando os números apresentados na reportagem, os seis milhões de filiados à CGT comporiam cerca de $37 \%$ da população adulta, e não $10 \%$ como explicita a matéria.

Ainda que não representassem $90 \%$ da população, como queria a reportagem, uma multidão antiperonista saiu às ruas em outubro para apoiar a queda do regime e rasgar os retratos do presidente. Para os jornalistas de O Cruzeiro, fora "a classe média esclarecida [...] e as reservas insubornáveis das três armas, que derrubaram Perón". 403 Em “Adeus, Perón, Bem-vindo, Lonardi”, a revista buscou entender a "popularidade do novo governo na classe média":

Essa gente representa a parcela mais esclarecida do povo argentino e está disposta a derramar sangue para que Perón não volte, como dispostos estavam os civis que lutaram ombro a ombro com os militares, nos quartéis e nas ruas de Córdoba, cidade-berço da revolução que restituiu a liberdade ao povo da República do Prata. ${ }^{404}$

Carlos Lacerda não perdeu a oportunidade de saudar a "aleluia argentina". Ele asseverou que o "Brasil, no que tem de mais consciente e verdadeiramente representativo, saúda a queda de Perón”. Em pleno contexto eleitoral brasileiro, ele defendeu a liderança política dos "grupos mais esclarecidos", a fim de evitar o que chamou de "tirania do número" e "o despotismo exercido em nome das maiorias". Escreveu ele:

\footnotetext{
${ }^{402}$ SILVA, Arlindo e DAMM, Flavio."O comediante da Plaza de Mayo" In O Cruzeiro, Rio de Janeiro, 24/9/1955.

${ }^{403}$ LEMOS, Ubiratan; WANDERLEY, Indalécio e RONEK, Antônio. "Adeus, Perón, Bem-vindo, Lonardi” In O Cruzeiro, Rio de Janeiro, 8/10/1955.

${ }^{404}$ Ibidem.
} 


\begin{abstract}
A crise de maturidade de nossas nações não permite alternativa, não admite soluções parciais nem contemporização por perplexidade ou por divisionismo. Ou os movimentos se desencadeiam sob a direção dos grupos mais esclarecidos, mais apercebidos dessa realidade, para permitir ao país que o seu "coming of age", a sua transição de nação semifeudal, primária e precária, para nação moderna, industrial e de reforma agrária, ou se processam através de penosos caminhos como o do movimento peronista, que ensanguentam as nações depois de tiranizá-las - inclusive pela tirania do número, o despotismo exercido em nome das maiorias, sejam estas as dos "humildes" a que se referia, hipocritamente, a carta falsa atribuída a Vargas, ou a dos descamisados, segundo expressão bem conhecida de Perón. ${ }^{405}$
\end{abstract}

Surpreendentemente, está ausente nas crônicas, editoriais e reportagens lidas a associação entre o voto dos analfabetos, permitido na Argentina desde o século XIX, e a alegada insciência das massas. Seria de se esperar que tal relação fosse astuciosamente explorada pela oposição brasileira, já que os udenistas eram veemente contra implantação desse direito no país. ${ }^{406}$ Aparentemente, porém, o assunto acabou passando em brancas nuvens.

Pode-se especular que isso ocorreu devido às diferentes realidades. No ano de 1950 , cerca de $50,5 \%$ da população brasileira com mais de 15 anos era analfabeta. ${ }^{407}$ Um censo feito na Argentina em 1947 concluiu que naquele país os iletrados maiores de 14 anos eram apenas $13,6 \%$ da população. Convenientemente, nenhum meio de comunicação estudado aqui citou o nível de alfabetização no país vizinho, consideravelmente superior ao do Brasil. Afinal, tal informação contrariava a imagem da ignorância das multidões difundida nos periódicos.

Igualmente, importa destacar que, em uma última tentativa de negar a popularidade do peronismo entre uma parte da população, alguns analistas lançaram mão de um capcioso jogo de palavras em que diferenciavam o termo povo de massa. Escreveu Austregésilo de Athayde: "Não se pode confundir o povo argentino com a massa de trabalhadores, vindo de todos os pontos da terra, que se concentram em Buenos Aires e apoiam a ditadura do General Perón. O bom povo argentino origina-se

\footnotetext{
${ }^{405}$ LACERDA, Carlos. "Aleluia argentina e paixão brasileira". Tribuna da Imprensa, Rio de Janeiro, 20/9/1955, p. 4.

${ }^{406}$ O voto aos analfabetos só passou a existir no Brasil em 1985. Sobre a posição da UDN contrária a esse direito, ver: BENEVIDES, op. cit., p. 278.

${ }^{407}$ FERRARO, Alceu Ravanello. "Analfabetismo e níveis de letramento no Brasil: o que dizem os censos?". Educ. Soc., Campinas , v. 23, n. 81, Dec. 2002 . Disponível em $<$ http://www.scielo.br/scielo.php?script=sci_arttext\&pid=S0101-

$73302002008100003 \& \operatorname{lng}=$ en\&nrm=iso>. Acesso em 14 Jan. 2015.
} 
noutra cepa". ${ }^{408}$ Na legenda de uma foto publicada em Tribuna da Imprensa também se podia ler:

Populares apredrejam a sede do Partido Peronista em Buenos Aires. Depois de longos anos de opressão o povo argentino saiu às ruas para manifestar, às vezes com violência, o seu profundo repúdio à tirania de Juan Domingo Perón, derrubado pela revolução. Aos antigos movimentos de massa, organizados e dirigidos pela CGT, sucederamse as manifestações do povo. ${ }^{409}$

Enfim, como se pode notar nas várias fontes citadas, a popularidade de Perón com uma parte da população argentina foi retratada não como uma escolha racional por parte de seus seguidores, mas como resultado da intensa propagada e do autoritarismo do líder perante a um grupo social que teria consciência "rebaixada ou deformada" e que agiria conforme seus instintos animais. A esses apoiadores "fanatizados" se oporia um parcela racional e consciente, que teria o mérito de manter sua capacidade de resistência e discernimento diante de um governo espúrio e violento.

A ideia de que havia, nas palavras de Lacerda, uma "tirania do número", exercida por uma massa fanática, bárbara e movida pelo ressentimento, foi uma representação que, como tantas outras, buscou tirar legitimidade da experiência política justicialista. Ela relaciona-se à noção de que imperava no país um regime de força que, demagogicamente, alegava defender os mais pobres. As imagens que se sucederam nesse esforço convergiram para a representação de uma Argentina que regredira ao estágio de barbárie.

A noção de um país cindido entre o "povo esclarecido" e a "massa fanática", como se viu, acabava por eclipsar os diferentes interesses de classe envolvidos na disputa de poder naquele país. Essa polarização remete, novamente, ao dualismo entre o bem e o mal, que impedia a compreensão da complexidade da política platina no período.

\footnotetext{
${ }^{408}$ ATHAYDE, Austregésilo de. "Poder e glória" In O Cruzeiro, Rio de Janeiro, 4/6/1955.

409 "Apoteose de liberdade na capital argentina" In Tribuna da Imprensa, Rio de Janeiro, 24-25/9/1955, p. 1.
} 
Como eu temia, o general Perón procurou logo apresentar-se na ribalta continental, como se ele e Vargas fossem uma espécie de Castor e Pollux da mitologia populista. [...] Em suma, desde o primeiro dia da atual administração brasileira [de Vargas], o General Perón sempre constituiu um problema inquietante para a nossa política externa. S. Exa. sempre se julgou estranhamente autorizado a opinar nos assuntos mais íntimos do Brasil, com o ouvido colado à fechadura da fronteira, escutando os menores rumores da nossa intimidade, tomando partido nas desavenças dos políticos, distribuindo folhetos de propaganda nos quais por vezes se exaltava a excelência do seu regime em contraste com a democracia brasileira [...] Durante estes três anos, não pararam as "lançadeiras", tecendo entre as duas capitais os fios de um intriga internacional.

João Neves da Fontoura (1954) ${ }^{410}$

\section{Capítulo 3 \\ Os conspiradores (1953-1955)}

${ }^{410}$ FONTOURA, op. cit.. 


\subsection{Novas acusações de imperialismo}

No início dos anos de 1950, o horizonte parecia promissor para os governos latino-americanos de esquerda e com viés nacionalista. Somada à reeleição de Perón (1951), venceram seus pleitos Getúlio Vargas (1950), o equatoriano José María Velasco Ibarra (1952), o boliviano Víctor Paz Estenssoro (1951) e o chileno Carlos Ibáñez del Campo (1951). De acordo com Mônica Hirst, “deve-se ainda mencionar o crescimento de forças partidárias como, por exemplo: os Autênticos em Cuba, a Ação Democrática na Venezuela, o APRA no Peru e os socialistas na Guatemala". 411

Para os cronistas políticos, o dedo peronista nessa nova conjuntura era evidente. Relativamente rica e com diplomacia bastante ativa, a Argentina era vista como o centro das "agitações" que estariam dominando o sul do continente americano. Temia-se, em especial, a formação de um "bloco latino-americano de contornos peronistas ou justicialistas a fim de contrabalançar com o chamado imperialismo norte-americano". 412 Ao visitar exilados argentinos no Uruguai, governado pelo colorado Andrés Martínez Trueba, David Nasser fustigou:

\footnotetext{
Perón instalou Paz Estenssoro na Bolívia, Ibañez no Chile, impôs o Presidente ao Paraguai [Federico Chaves] e a outras nações, mas não consegue meter o nariz no Uruguai, que fica bem debaixo de seu nariz. Por quê? Uns dizem que ele não quer destruir o seu único refúgio possível, em caso de queda, pois, democraticamente, o Uruguai asila até os seus inimigos de ontem. ${ }^{413}$
}

Para o cronista político Theóphilo de Andrade, o novo quadro relacionava-se ao caudilhismo, cujas origens remontariam à violenta colonização espanhola. "Essa gente, esse sangue, essa raça criaram, na América, o caudilhismo como instituição que os compêndios de filosofia política nunca puderam classificar...", afirmou. De acordo com ele, essa "doença incurável, de recidivas incontroláveis" estava a adquirir contornos modernos por meio de democracias de fachada, nas quais se mobilizava "a sede de justiça, segurança e igualdade do proletariado" a favor de líderes autoritários. Ele completou:

\footnotetext{
${ }^{411}$ HIRST, Mônica. O Pragmatismo Impossível: A Política Externa do Segundo Governo Vargas. Rio de Janeiro: Editora do CPDOC, 1990. p. 29.

${ }^{412}$ NASSER, David. "Resposta ao governo da Bolívia - Fantoche de Perón" In O Cruzeiro, Rio de Janeiro, 26/9/1953.

${ }^{413}$ NASSER, David e KEFFEL, Ed. "Pimenta nos olhos dos outros - O suplício das telefonistas" In $O$ Cruzeiro, Rio de Janeiro, 18/10/1952.
} 
[...] Os exemplos pululam por trás de cada montanha. Na Argentina, Juan Domingo Perón, um caudilho sorridente, destruiu a democracia, e está a tornar-se um perigo continental, visto que encarna o espírito de Rosas e pretende restaurar o antigo Vice-Reinado do Prata. Na Bolívia, Paz Estenssoro, financiado por Perón, entra em La Paz sobre três cadáveres. No Equador, Velasco Ibarra vem pelas armas reconstruir a ditadura. E agora, no Chile, o antigo Coronel Carlos Ibañez, ex-Ditador, e atual aliado de Perón, é reconduzido ao poder pelo voto popular, porque levantou a bandeira nacionalista.

Mudaram os tempos. E mudaram os métodos. Mas o fenômeno do caudilhismo permanece como uma constância latino-americana, através das idades.

Será que o sangue espanhol não tem vocação para a democracia? ${ }^{414}$

Em relação à Bolívia, houve grande interesse de $O$ Cruzeiro, especialmente nos primeiros anos da década. Em 1951, Paz Estenssoro, encabeçando o MNR (Movimiento Nacionalista Revolucionario), venceu as eleições presidenciais, mas foi impedido de tomar posse por causa de um golpe de Estado executado pelo regime conservador. Em abril do ano seguinte, a Revolução Boliviana finalmente o conduziu ao poder, tendo início um mandato com tendências de esquerda nacionalista. Nesse ínterim, Perón foi acusado de apoiar líderes políticos de diferentes tendências com o objetivo "de envolver a Bolívia na trama de seu domínio de imperialismo econômico e militar”. De acordo com uma reportagem da revista, ao aumentar sua influência sobre La Paz, o justicialismo buscaria estabelecer "um cerco diplomático e econômico" ao Brasil. ${ }^{415} \mathrm{Na}$ cobertura dos violentos conflitos de 1952, a revista também destacou a abundante propaganda política argentina:

\begin{abstract}
Quase todos os países americanos mandaram a La Paz socorros de emergência para os milhares de feridos da revolução. $O$ trabalho dos médicos e enfermeiras venezuelanos, a assistência dos chilenos, dos panamenhos, dos norte-americanos foram exemplares. Os argentinos chegaram em quatro ou cinco quadrimotores, envergando vistosos uniformes não da Cruz Vermelha, mas da Fundação Eva Perón, e despejaram, ao lados dos víveres e dos remédios, massas de retratos, livros, folhetos, cartazes de propaganda peronista. Muitos incidentes ocorreram em consequência. Em La Paz espalhou-se a versão de que Perón mandara oito toneladas de carga [sic], mas nela se incluíam sete toneladas de retratos da senhora Eva Perón e material de propaganda do justicialismo. O fato é que a ostentação, a propaganda, o "show" chocaram um país de grande pundonor nacional e essa falta de medida é o que vale à América na apreciação do fenômeno peronista no sul do continente. ${ }^{416}$
\end{abstract}

\footnotetext{
414 ANDRADE, Theophilo de. "Caudilhos \& Pronunciamentos" In O Cruzeiro, Rio de Janeiro, 27/9/1952, p. 14.

${ }^{415}$ MOREIRA, Neiva e KANAI, Utaro. "Há uma força em meu caminho" In O Cruzeiro, Rio de Janeiro, 28 de julho de 1951.

${ }^{416}$ MOREIRA, Neiva e DAMM, Flavio. "Estenssoro rasga o jogo da nacionalização" In O Cruzeiro, Rio de Janeiro, 17 de maio de 1952.
} 
Ainda que Estenssoro negasse em entrevista a interferência platina, a legenda de uma foto denunciava a influência do governo de Buenos Aires: "PERÓN, sombra ameaçadora, capitalizando as inquietações sociais e o desespero econômico dos países mais fracos da América Latina". 417

Após medidas como a nacionalização das reservas minerais e a reforma agrária, a abordagem sobre o novo governo boliviano tornou-se ainda mais sulfúrica, com reportagens repletas de ataques pessoais ao presidente e pouca análise política mais profunda. Como em outras ocasiões, os textos mais ferinos partiram da lavra de David Nasser, que definiu o mandatário de La Paz como um "fantoche de Perón", que teria estabelecido um governo "comunista por princípio, peronista por conveniência". Nasser afirmou que a revolução utilizara armas e financiamento oriundos de Buenos Aires e que resultara em um governo profundamente autoritário. E emendou: "Custou sete mil vidas a aventura justicialista e a volta de Paz Estenssoro ao poder. Não eram vidas argentinas, mas bolivianas. Nem Perón nem Paz Estenssoro, por isso, deram importância ao tributo de sangue". 418

O Uruguai recebeu especial atenção nos meses finais de 1952, quando enfrentou uma grave crise diplomática com a Argentina. A relação entre os dois países não vinha bem há anos. Havia rumores de que o justicialismo financiara o candidato blanco, Luis Alberto de Herrera, derrotado na campanha presidencial de $1950 .{ }^{419}$ De acordo com Daniela Xavier V. G. Santos, a "opinião pública uruguaia, até mais do que a brasileira, tinha profundas desconfianças em relação à Argentina e a Perón". 420

Uma série de eventos havia prejudicado ainda mais o cenário. Entre outras coisas, o Uruguai acusava o vizinho de interferência indevida mediante o fomento a greves por meio dos adidos operários ligados à embaixada em Montevidéu. Em resposta, a Argentina criticava a proteção recebida pelos exilados antiperonistas, que podiam agir livremente do outro lado do rio da Prata. Perón chegou a ameaçar um rompimento de relações, mas acabou optando por uma "agressiva campanha de imprensa contra o Uruguai". ${ }^{421}$ Com os ânimos exaltados, não eram poucos os que temiam que a situação degringolasse para a luta armada.

\footnotetext{
${ }^{417}$ Idem.

${ }^{418}$ Nasser, David. "Resposta ao governo da Bolívia - Fantoche de Perón" In O Cruzeiro, Rio de Janeiro, 26/9/1953.

${ }^{419}$ SANTOS, op. cit., p. 66.

${ }^{420}$ Ibidem.

${ }^{421}$ Ibidem, p. 68.
} 
Como era de se esperar, O Cruzeiro defendeu o Uruguai, tido como uma "democracia modelar" ${ }^{422}$ e "um David que enfrentava corajosamente um Golias". 423 Uma reportagem de Neiva Moreira e Flávio Damm ressaltou o "assalto em marcha" contra o "valente povo de três milhões de habitantes". E insistiu que o regime justicialista se inspirava no rosismo. Em suas palavras:

\begin{abstract}
Ameaças militares, pressão econômica, intervenção sindical aberta e abusiva, hostilidade fronteiriça, tudo isso vêm sendo operado por Perón para intimidar o Uruguai e forçá-lo a entrar na esfera de ação de Buenos Aires. É esse um velho sonho do vice-reinado do Prata, que a casta militarista argentina, reunida no conhecido GOU, ainda alimenta. ${ }^{424}$
\end{abstract}

No início de 1953, as atenções se voltaram para o Chile. Após apoiar abertamente a eleição do general Ibañez del Campo, Perón fez-lhe uma visita cercada de pompa entre 20 e 26 de fevereiro. Dias antes, o presidente argentino dera uma entrevista na qual defendera que, mais do que a união econômica, era necessário fazer a "união total e não pela metade" das duas nações. ${ }^{425}$ De acordo com a historiadora Leonor Machinandiarena de Devoto, essas declarações sobre uma possível união política "geraram no país vizinho [Chile] grande mal-estar, subindo o tom das polêmicas já provocadas pela iminente viagem do presidente argentino". 426

A chegada faustosa da comitiva justicialista apenas uma semana antes das eleições parlamentares chilenas gerou protestos de jornais e políticos opositores a Ibañez, com acusações de interferência peronista em questões internas. Apesar de alguns constrangimentos, os encontros entre os dois mandatários culminaram na assinatura da Ata de Santiago, um acordo econômico significativo que previa redução de tarifas aduaneiras por parte dos dois países. ${ }^{427}$ No documento, abria-se a possibilidade de adesão de outras nações do continente.

Enquanto a imprensa argentina celebrou a resolução, O Cruzeiro retratou a visita como uma grande derrota de Perón. De acordo com Wilson Aguiar e Eugênio Silva, após a desastrosa entrevista, o líder justicialista tivera suas intenções imperialistas

\footnotetext{
422 MOREIRA, Neiva e DAMM, Flavio. "Perón assalta o Uruguai" In O Cruzeiro, Rio de Janeiro, $3 / 1 / 1953$.

${ }^{423}$ SILVA, Arlindo. ""O Cruzeiro" lutou contra o ditador Perón" In O Cruzeiro, Rio de Janeiro, 15/10/1955.

${ }^{424}$ MOREIRA, Neiva e DAMM, Flavio. "Perón assalta o Uruguai" In O Cruzeiro, Rio de Janeiro, 3/1/1953.

${ }^{425}$ DEVOTO, Leonor Machinandiarena de. Las relaciones con Chile durante el peronismo: 1946-1955. $1^{\mathrm{a}}$. Ed., Buenos Aires, Lumière, 2005, p. 238.

${ }^{426}$ Ibidem, p. 239.

${ }^{427}$ CAVLAK, op.cit., p. 50.
} 
desmascaradas pela ação enérgica da imprensa e da oposição conservadora chilena. Seu verdadeiro objetivo, o "anchluss" (anexação) do Chile, teria naufragado e ele voltara "a Buenos Aires sem borrar os Andes. Pelo contrário, mais alta estava a cordilheira separando os dois países, pois que mais acima se colocou a altivez e o patriotismo do povo chileno". ${ }^{428}$ Após destacar novamente a "verdadeira onda de publicidade peronista" em terra estrangeira, os jornalistas apontaram diretamente o presidente argentino como principal responsável pelo fracasso:

\begin{abstract}
Acreditamos ser os amigos uma necessidade do "justicialismo", principalmente para a expansão de sua doutrina. Porém, o organismo de fazer os amigos do "justicialismo" é uma verdadeira fábrica de inimigos: Perón. Tais foram os caminhos tortuosos percorridos pelo Presidente Perón no Chile, que os chilenos que estavam dispostos a se tornarem amigos de Perón, hoje são seus piores inimigos. ${ }^{429}$
\end{abstract}

Como se verá, temia-se nesse momento que as articulações de Perón redundassem no chamado Pacto ABC (Argentina, Brasil e Chile), um acordo econômico entre as três nações evocado há tempos pelo mandatário argentino. Em Tribuna da Imprensa, uma charge, provavelmente de Hilde, traduziu a ideia do Pacto $A B C$ como um arapuca continental (figura 11). Nela, Perón aparece em trajes aparentemente escolares a equilibrar um bloco com as iniciais das três nações. Sua feição não deixa dúvidas a respeito das intenções perversas do projeto.

Chama atenção seu isolamento na cena, ou seja, a ausência de líderes de Chile e Brasil que, subentende-se, estariam sendo manipulados. Também curiosas são suas vestimentas que, numa outra chave de leitura, remetem à ideia de uma molecagem, uma travessura irresponsável. Há efeito cômico ao colocar o líder justicialista, tão sisudo e poderoso, em trajes pueris. Fica implícita ainda a ideia de que ele possuiria a personalidade de uma criança mimada e, ao mesmo tempo, megalomaníaca. Por fim, pode-se pensar que, do ponto de vista da artista, o Pacto $A B C$ não passaria de uma aventura tão imatura e imprudente quanto uma brincadeira infantil.

\footnotetext{
${ }^{428}$ AGUIAR, Wilson e SILVA, Eugenio. "Perón desmascarado no Chile. Beijos e 30 dinheiros" In $O$ Cruzeiro, Rio de Janeiro, 11/4/1953.

${ }^{429}$ Idem.
} 


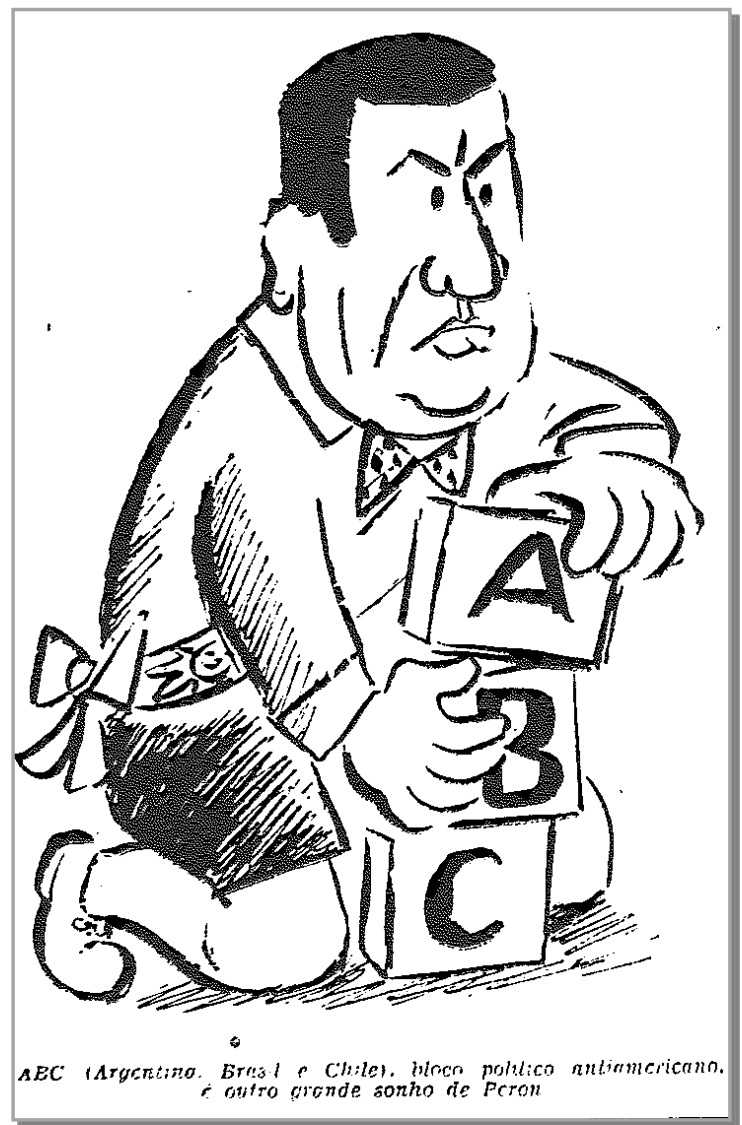

Figura 11 - Autoria desconhecida. Tribuna da Imprensa, 25/09/1952, p. 12

Por fim, foi a vez de o Paraguai ser apontado como caudatário de Buenos Aires. Em 1954, um golpe militar contra o presidente eleito Federico Chaves gerou contentamento no Brasil, pois seu novo líder, o general Alfredo Stroessner, era tido como simpatizante do país. ${ }^{430}$ No entanto, o novo regime paraguaio, confirmado em eleições com candidato único, não se afastou da Argentina peronista. Ao contrário, o país guarani, tido como "peça vital nos sonhos peronistas de hegemonia e expansão" do "hitlerzinho portenho", ratificou os acordos econômicos encetados na Ata de Santiago. ${ }^{431}$ No Brasil, a suntuosa visita de Perón a Stroessner em agosto de 1954 parecia confirmar a ampliação da órbita justicialista e provocou reações indignadas:

PERÓN tomou de assalto a República do Paraguai, consolidando espetacularmente uma posição de predomínio que vinha sendo trabalhada desde 1946. A sua visita a Assunção, no dia 15 de agosto, foi a entrada de um General vitorioso num baluarte conquistado. Ampliou-se a frente peronista na América Latina, de uma forma habilidosa e positiva. Chile e Bolívia já estavam sob a influência direta do caudilho portenho. A esses países juntouse, agora, a pátria do Marechal Solano Lopez. E não se diga que a queda do

\footnotetext{
${ }^{430}$ PEARSON, Drew. “A revolta no Paraguai e Perón” In O Cruzeiro, Rio de Janeiro, 10/7/1954.

${ }^{431}$ MARTINS, João e RONEK, Antônio. "Nos bastidores da intriga internacional - Política e sangue no Paraguai” In O Cruzeiro, Rio de Janeiro, 12/06/1954.
} 
Paraguai se deu sem nenhum tiro. O processo é longo, dura oito anos. Balas peronistas deflagraram, em 1947, para salvar Morínigo, quando uma revolução popular já havia decretado a queda do ditador, quando os Exércitos rebeldes batiam às portas de Assunção. Nas revoluções subsequentes, o dedo de Perón sempre esteve em ação. Depois Evita - que Deus se compadeça de sua alma - passou a comandar a linha auxiliar de penetração argentina, através da caridade, dando pão aos famintos, agasalhando os que tinham frio, assistindo os necessitados. A caridade era feita ao som de clarins, à moda farisaica, com frutos surpreendentes. Morreu Evita, mas Perón continuou a demagogia esmoleira, aproveitando-se da situação de dificuldades que o bravo, o bom, o heroico, o sofrido povo paraguaio (vítima de tiranias desalmadas que no poder sempre estiveram absorvidas pela preocupação da própria estabilidade, raramente com os problemas da nação) vem atravessando há decênios. E Perón faz da fome e do frio os seus grandes generais. Resultado: o Paraguai rendeu-se ao "justicialismo". ${ }^{42}$

A devolução dos troféus da Guerra do Paraguai foi retratada como uma atitude peronista demagógica, que teria sido acompanhada pela imprensa argentina, responsável por "deformar" episódios para enfatizar o imperialismo brasileiro e isentar seu próprio país das catastróficas consequências do conflito. A imensa popularidade de que gozava Perón no país vizinho foi novamente noticiada em tom de alarde:

Na recepção de Perón no Paraguai, as explosões de júbilo do povo tiveram um cunho mais profundo, mais sério, mais penetrante. Não se saudava a Argentina, mas um líder, um salvador, uma esperança, um condutor de destinos da América Espanhola. E não se fazia a aproximação dos dois povos apenas a "favor" de alguém, ou de alguma coisa, ou de duas nações. Fazia-se também "contra" alguém. Não se falou no imperialismo norte-americano, tema sediço de Perón. Falou-se, e muito, no "imperialismo brasileiro". ${ }^{433}$

Como se pode notar, uma nova conjuntura política sul-americana, marcada pela ascensão de líderes populares e nacionalistas, parecia reforçar as posições geopolíticas de Perón e sua opção por blocos regionais, e não continentais. Essa sensação de que estaria ocorrendo o fortalecimento do justicialismo no plano internacional impôs-se, malgrado a situação econômica interna do país, que se deteriorou consideravelmente no início dos anos de 1950. Paradoxalmente, enquanto as bases do seu poder eram silenciosamente corroídas, as representações de Perón como líder imperialista se fortaleciam nos países vizinhos.

\footnotetext{
${ }^{432}$ FERREIRA, Jorge e PINTO, José. "Perón invade o Paraguai" In O Cruzeiro, Rio de Janeiro, $27 / 11 / 1954$

${ }^{433} \mathrm{Idem}$
} 


\subsection{Denúncias de infiltração sindical e jornalística}

A propaganda justicialista também esteve muito presente no Brasil. Denúncias envolvendo a atuação diplomática peronista no Brasil foram constantes, principalmente na Tribuna da Imprensa. Elas se concentraram principalmente em dois aspectos: o envio, via embaixada, de livros e folhetos peronistas aos sindicatos e as tentativas de cooptação de sindicalistas locais para integrar a Agrupación de Trabajadores Latinoamericanos Sindicalistas (ATLAS).

Essas denúncias estiveram bastante relacionadas à atuação dos adidos obreros (ou adidos trabalhistas/operários) enviados pelo governo de Buenos Aires. O cargo já existia no serviço diplomático de alguns países, como Estados Unidos, França e Inglaterra. No caso argentino, ele foi implantado por Perón a partir de 1946. Seus representantes atuavam com outros tipos de adidos (militar, cultural, comercial etc). Tratava-se de dirigentes sindicais indicados pelos seus próprios grêmios. Antes de serem designados para uma representação diplomática, faziam um curso preparatório com duração de três meses a dois anos. Segundo Cláudio Panella, 485 homens e mulheres se formaram e 108 chegaram a exercer funções no exterior. ${ }^{434}$ Para a retórica peronista, era mais uma maneira de incorporar os descamisados aos centros decisórios tradicionais, dando-lhes a incumbência de aproximar os trabalhadores argentinos aos de outras partes do mundo. As oposições sul-americanas, porém, viam na iniciativa mais uma prova do imperialismo megalomaníaco do regime.

Ao longo dos anos, o trabalho dos adidos trabalhistas gerou diversos incidentes diplomáticos, com acusações constantes de intervenção na vida interna de outras nações. O caso mais emblemático foi o do Uruguai, que em 1952 expulsou os dois adidos obreros justicialistas sob a acusação de fomentar greves no país.

De acordo com Claudio Panella, a atuação desses funcionários no Brasil foi bem mais discreta, especialmente durante os anos Dutra, pois o governo, a chancelaria e os grandes jornais eram "decididamente pró-norteamericanos e antiargentinos". Segundo um adido do período, estes temiam que "os contatos dos representantes laborais argentinos com trabalhadores brasileiros significassem uma tomada de consciência

\footnotetext{
${ }^{434}$ PANELLA, Claudio. "Los agregados obreros" In Revista Todo es Historia, n 328, octubre 1994, p. 38.
} 
destes sobre seu péssimo nível de vida e, em consequência, a possibilidade de atuar a respeito frente aos patrões e ao governo". ${ }^{435}$

Isso, porém, não evitou episódios delicados, como o que ocorreu em 1947, quando o alfaiate argentino Cipriano Barreiro, recém-indicado para o cargo no Rio de Janeiro, provocou celeuma ao criticar nos jornais o nível de vida dos trabalhadores brasileiros. ${ }^{436}$ Havia também um desconforto silencioso por parte do Itamaraty. De acordo com Iuri Cavlak, o órgão não via com bons olhos os constantes convites feitos pelos agregados obreros aos sindicalistas brasileiros para conhecerem a Argentina justicialista e, não raro, o próprio Perón. ${ }^{437}$

Em relação à distribuição de livros e folhetos panegíricos ao justicialismo e a seu mentor, a reação foi frequentemente contundente. Notícias a respeito já eram recorrentes nos diários e revistas brasileiros desde o final dos anos 1940 e continuaram ecoando. Para a historiadora Marisol Saavedra, essa controversa tática do regime peronista acabou por converter-se em uma "obsessão brasileira". De acordo com o relato de um diplomata platino do período,

[...] a cada quatro ou cinco dias, no Congresso ou nos jornais se alçava alguma voz para destacar o perigo que ela [propaganda peronista] implicava. Qualquer publicação sobre aspectos da realidade argentina que chegava ao país era considerada "subversiva". ${ }^{43}$

Em certa ocasião, por exemplo, a Tribuna da Imprensa apelidou a embaixada argentina de "agência de propaganda peronista". ${ }^{439}$ A estridência do jornal de Carlos Lacerda a respeito do tema pode ser observada no fac-símile da primeira página apresentado a seguir.

\footnotetext{
435 Ibidem, p. 46.

${ }^{436}$ Ibidem, p. 51.

${ }^{437}$ CAVLAK, op. cit., p. 124-125.

${ }^{438}$ Apud SAAVEDRA, op. cit., p. 30.

439 “O peronismo por dentro e por fora (III)” In Tribuna da Imprensa, Rio de Janeiro, 13-14/9/1952, p. 4, $2^{\circ}$ caderno.
} 


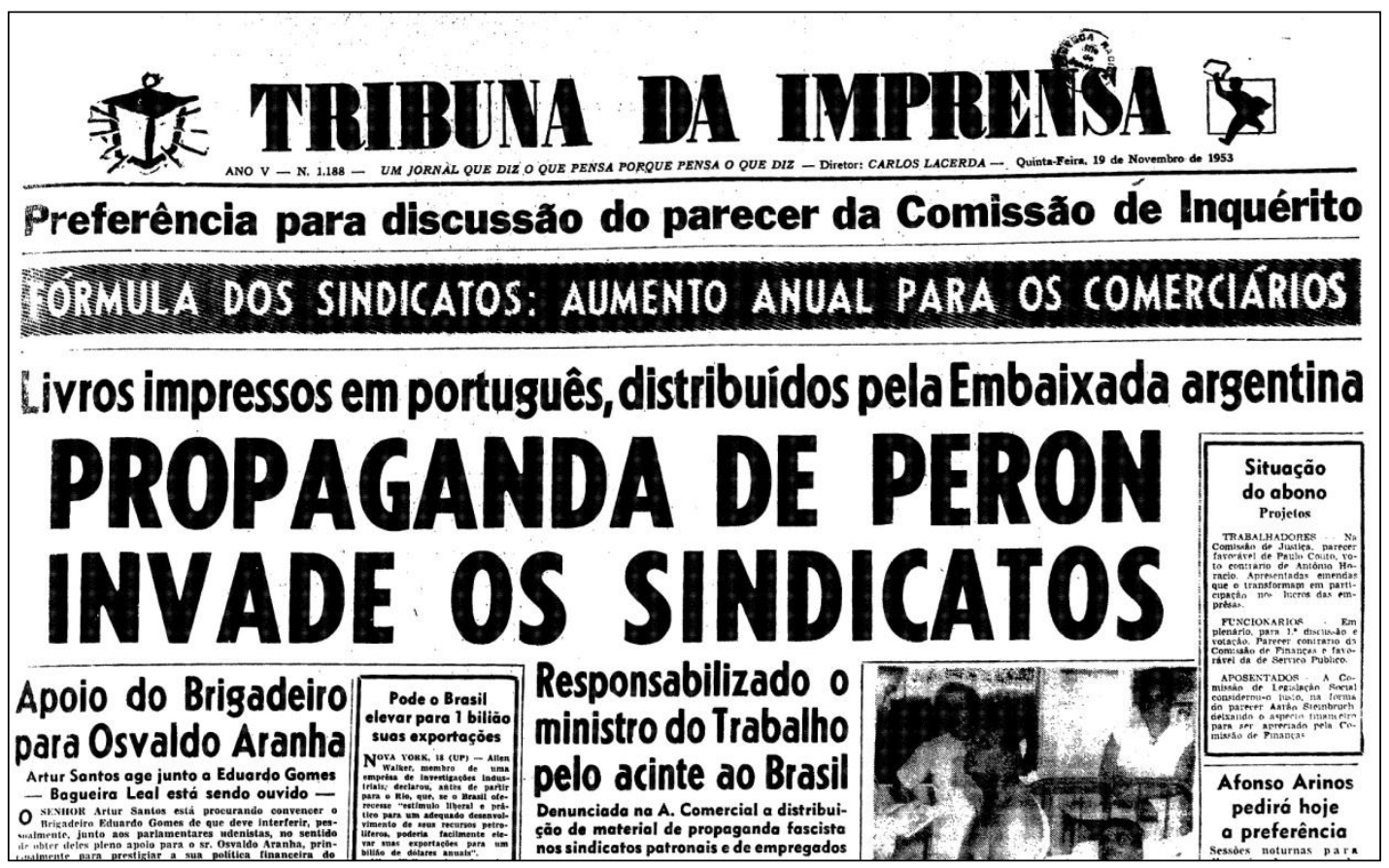

Figura 12 - Fac-símile da $1^{a}$ página da edição de 19 de novembro de 1953.

$\mathrm{Na}$ notícia, diretores da Associação Comercial do Rio de Janeiro mostraram indignação com o envio de livros em língua portuguesa e apologéticos ao regime aos sindicatos patronais e de empregados brasileiros. Alegaram que essa prática da embaixada argentina havia se intensificado enormemente após a posse de João Goulart como ministro do Trabalho, que seria conivente. Para um dos diretores, tais obras deveriam ser queimadas em praça pública. ${ }^{440}$

A consulta a alguns desses livros, preservados em bibliotecas e sebos, indica que muitos foram impressos em gráficas de Buenos Aires. ${ }^{441}$ No entanto, houve ao menos um escritor que produziu obras a partir do Brasil. Trata-se do espanhol Pascual Nuñez de Arca que assinou ao menos duas obras apologéticas: A verdade argentina - A luta de um povo por sua liberdade econômica ${ }^{442}$ e De Quitandinha a Bogotá passando por Buenos Aires; reportagens de duas conferências e duas viagens. ${ }^{443}$

\footnotetext{
440 "Propaganda de Perón invade os sindicatos" In Tribuna da Imprensa, Rio de Janeiro, 19/11/1953, p. 1 ${ }^{441}$ Ver, por exemplo: MENDE, Raul A. "O justicialismo - doutrina e realidade peronista". Buenos Aires, 1952.

${ }^{442}$ NUÑEZ ARCA, P. e PLANTÓN, Juan Pedro. A verdade argentina: a luta de um povo por sua liberdade econômica. São Paulo, Letras Editora Continental, 1950, 112 p.

${ }^{443}$ NUÑEZ ARCA, P. De Quitandinha a Bogotá passando por Buenos Aires: reportagens de duas conferencias e duas viagens. São Paulo : Letras Ed. Continental, s/d, 278 p.
} 


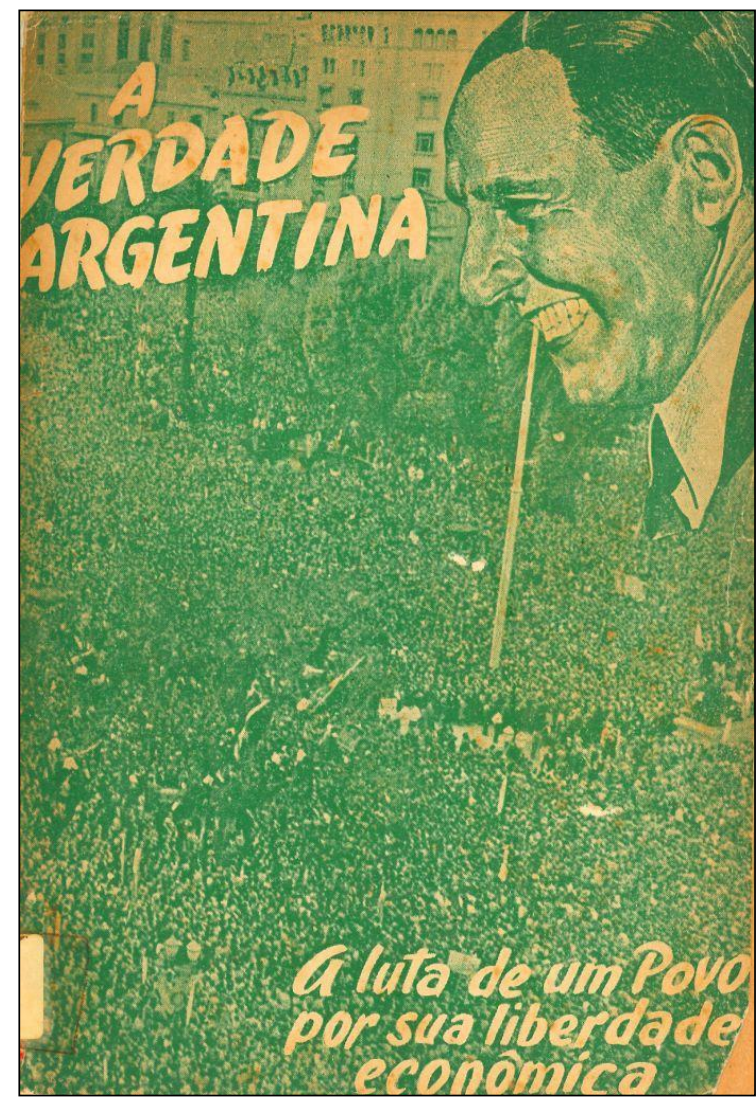

Figura 13 - Capa do livro de Pascual Nuñez de Arca, publicado no Brasil em 1950.

De acordo com o antiperonista Agustín Rodriguez Araya, Arca recebeu 40 mil pesos do governo argentino para escrever um de seus livros, quantia que considerou "fabulosa". Araya classificou-o como um mercenário, que atuaria com outros "traficantes da pena" pagos por Perón espalhados pelo continente. "Pouco lhes interessa o país, as instituições, a dignidade, se com ela juntam um pouco de dinheiro", assegurou. ${ }^{444} \mathrm{Na}$ ocasião, os cheques recebidos pelo escritor espanhol foram publicados pela Tribuna da Imprensa, que o qualificou como um "picareta". 445

Segundo o Correio da Manhã, essa "infiltração peronista" promovida por meio da distribuição desses livros e panfletos foi feita inicialmente pelos adidos obreros. ${ }^{446}$ Assim, não é por acaso que eles tivessem seus passos seguidos de perto especialmente

\footnotetext{
444 “Mercenários peronistas" In Tribuna da Imprensa, Rio de Janeiro, 20-21/10/1951, p. 1.

445 Pascual Nuñez de Arca esteve entre os jornalistas que tiveram sua inscrição rejeitada na sétima Assembleia da Sociedade Interamericana de Imprensa, realizada em Montevidéu, em 1951. Ele alegou representar a agência brasileira de notícias Asapress, mas, de acordo com a Tribuna da Imprensa, não possuía qualquer relação com essa empresa. Ver: "O espanhol peronista não representa coisa alguma" Coluna Prezado Leitor. Tribuna da Imprensa, Rio de Janeiro, 23/10/1951, p. 1.

446 "Adidos da Embaixada argentina à frente da propaganda peronista no Brasil” In Correio da Manhã, Rio de Janeiro, 19/06/1955, p. 22.
} 
pela Tribuna da Imprensa, que denunciava com frequência suas atividades e contatos nos meios sindicais.

Em 1952, por exemplo, o jornal trouxe informações a respeito do monótono primeiro dia da $V$ Conferência dos Estados Americanos Membros da Organização Internacional do Trabalho, realizada em Petrópolis. Não havia nenhuma novidade. O único destaque ficou por conta do discurso inaugural de Vargas em que ele louvara e prometera ampliação da legislação social brasileira. Minimizando as palavras do líder trabalhista, o jornalista Newton Carlos preferiu enfatizar a opinião do adido operário argentino. Este garantira: "O que disse Vargas é o mesmo que tem dito Perón". ${ }^{447} \mathrm{O}$ título da notícia ia nesse mesmo sentido: “Opinião dos pelegos argentinos: Vargas imita Perón”.

No dia seguinte à notícia, Hilde desenhou Vargas colocando uma máscara com a face do presidente platino. A imagem traz a denúncia de parentesco ideológico entre os dois presidentes. Novamente, não houve concessão ao líder justicialista, retratado com o semblante sisudo numa provável alusão à maneira autoritária com que lidava com seus adversários políticos.

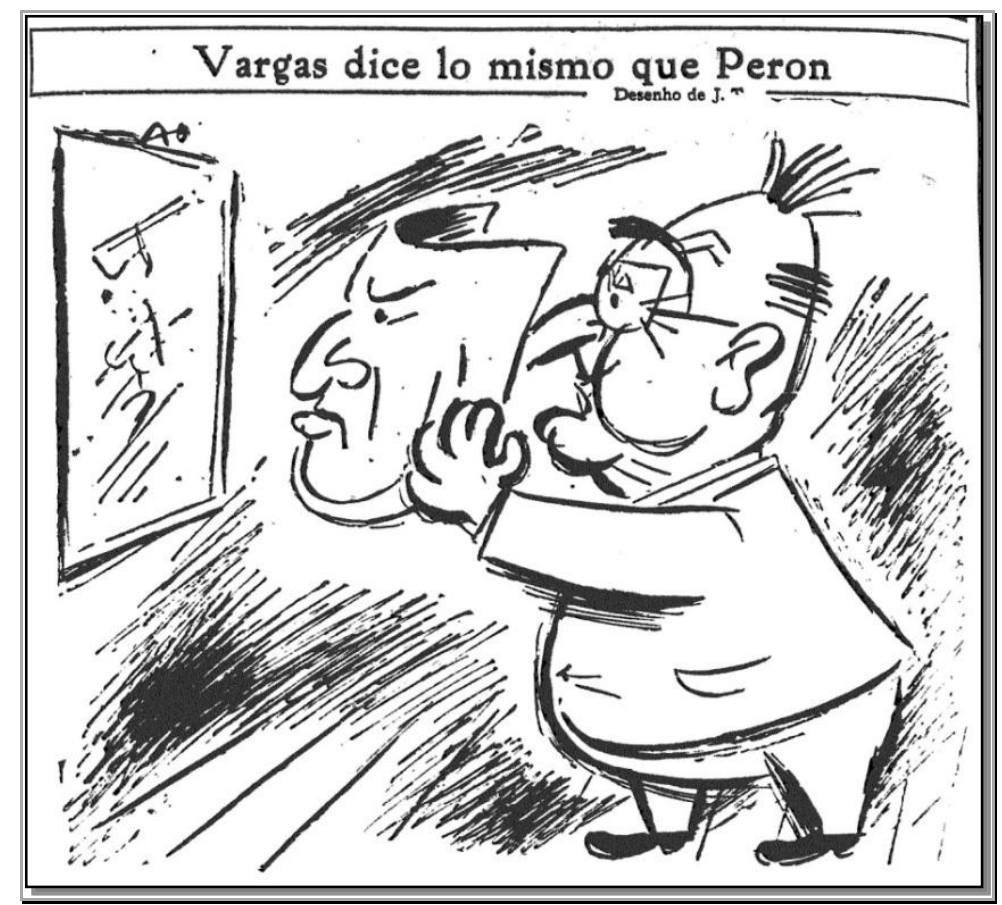

HILDE. Tribuna da Imprensa, 19-20/4/1952, p. 4

${ }^{447}$ CARLOS, Newton. "Opinião dos pelegos argentinos: Vargas imita Perón” In Tribuna da Imprensa, Rio de Janeiro, 18 de abril de 1952, p. 1 e 10. 
Em 1953, Tribuna da Imprensa forneceu informações bastante completas a respeito do "malicioso" George Hector Lupo, o novo adido operário no Rio de Janeiro, vinculado ao sindicato argentino dos telefonistas. Comunicou a data de sua chegada, sua atuação anterior nas Nações Unidas, os sindicatos e congressos que visitara no Brasil e suas viagens recentes a Buenos Aires. Tudo isso sob a manchete: "Perón invade os sindicatos brasileiros". 448

A suposta conivência das autoridades brasileiras em relação a tais atividades também foi criticada. De acordo com o jornal, outro adido trabalhista, de nome Vicente Diana, recebera permissão do Departamento Nacional do Trabalho, vinculado ao Ministério do Trabalho, para ministrar "aulas justicialistas" em suas dependências. ${ }^{449}$ Em outra ocasião, Diana teria usado o auditório do Ministério da Agricultura para comemorar o "Dia da Lealdade" peronista. ${ }^{450}$ Presidentes de sindicatos brasileiros que haviam assistido à posse de Perón a convite dos adidos também tiveram seus nomes apontados e foram chamados de "pelegos". 451

A Tribuna da Imprensa se gabava especialmente por dificultar a ação dos adidos operários argentinos que, em suas palavras, atuavam como "espiões disfarçados". ${ }^{452}$ Em 1952, deu ampla publicidade à declaração de Vicente Diana feita a círculos operários a respeito de um encontro secreto que ocorreria brevemente entre Vargas e Perón. De acordo com o jornal, tal "indiscrição" do adido trabalhista, noticiada ali com "absoluta exclusividade", teria culminado no adiamento da reunião por ordem do presidente brasileiro. ${ }^{453}$ Tempos depois, o vespertino orgulhou-se por ter contribuído para a remoção do mesmo Diana. Do seu ponto de vista, o funcionário fora "expurgado pelo alto comando peronista como agente fracassado" 454 após a forte reação de parte da imprensa brasileira contra a distribuição de material justicialista impresso. ${ }^{455}$

\footnotetext{
448 "Perón invade os sindicatos brasileiros" In Tribuna da Imprensa, Rio de Janeiro, 25/11/1953, p. 12.

449 CARLOS, Newton. "Rede de infiltração na América Latina” In Tribuna da Imprensa, 25/09/1952, p. 12.

${ }^{450}$ CARLOS, Newton. "Peronistas financiavam sindicatos brasileiros" In Tribuna da Imprensa, Rio de Janeiro, 20/6/1955, p. 8.

451 "Jango Goulart, aliado ao peronismo, dirige a campanha de "moralização" In Tribuna da Imprensa, Rio de Janeiro, 25-26/10/1952, p. 1 e 2.

452 "Novo agente peronista para o Brasil" In Tribuna da Imprensa, Rio de Janeiro, 28-29/11/1953, p. 2.

453 “Encontro Vargas-Perón” In Tribuna da Imprensa, Rio de Janeiro, 31/10/1952, p. 1.

454 "Perón invade os sindicatos brasileiros" In Tribuna da Imprensa, Rio de Janeiro, 25/11/1953, p. 12.

455 "Novo agente peronista para o Brasil” In Tribuna da Imprensa, Rio de Janeiro, 28-29/11/1953, p. 2.
} 
Muitas das notícias sobre esse tema foram escritas pelo jovem repórter Newton Carlos ${ }^{456}$, responsável por cobrir questões sindicais. Em uma delas, ele defendeu abertamente que a "infiltração peronista" estava colocando "em pleno desenvolvimento uma política acintosa de intromissão na vida pública, suborno de dirigentes sindicais e participação ativa em movimentos grevistas". ${ }^{457}$ Assegurou ainda que "300 agentes peronistas estão atualmente em atividade no Brasil", incluindo aí "elementos nativos trabalhando a soldo". 458

Manchetes a respeito se intensificaram a partir de 1952, quando o anúncio da CGT argentina da criação de uma central sindical de trabalhadores latino-americanos aumentou o alarme da oposição. Em consequência da Guerra Fria, havia até então duas grandes entidades desse tipo no continente. Alinhada aos norte-americanos, estava a Organização Regional Interamericana de Trabalhadores (ORIT), fundada em 1951 e vinculada à Confederação Internacional das Organizações Sindicais Livres (CIOSL). ${ }^{459}$ Do outro lado do espectro político, havia a Confederação de Trabalhadores da América Latina (CTAL), apoiada pelos soviéticos e tida como um braço da Federação Sindical Mundial (FSM).

Diversas notícias a respeito da formação de uma terceira central sindical, patrocinada pelo governo argentino, pulularam ao longo de 1952. A ideia se concretizou com a criação da ATLAS (Agrupación de Trabajadores Latinoamericanos Sindicalistas), no México, ao final daquele ano. Compareceram cerca de cem delegados oriundos de dezoito países do continente. Como era de se esperar, José Espejo, da CGT argentina, foi eleito secretário geral da entidade, que teve sua sede estabelecida em Buenos Aires. $^{460}$

\footnotetext{
${ }^{456}$ Newton Carlos de Figueiredo (Macaé-RJ,1927-?) era então um jovem repórter cujos artigos estavam bastante alinhados ao pensamento conservador de Carlos Lacerda. Anos depois, ele ficou conhecido por sua atuação jornalística na área de política internacional em diversos meios de comunicação, especialmente na Folha de S. Paulo.

${ }^{457}$ CARLOS, Newton. "Reação do governo uruguaio" In Tribuna da Imprensa, Rio de Janeiro, 24/10/1952, p. 12

${ }^{458}$ CARLOS, Newton. "Vitória de Ibañez e objetivos peronistas" In Tribuna da Imprensa, Rio de Janeiro, 4/3/1953, p. 3, $2^{\circ}$ caderno.

${ }^{459}$ Coincidentemente, o segundo Congresso da ORIT ocorreu no Rio de Janeiro, em dezembro de 1952. A representação argentina foi composta por três sindicalistas exilados no Uruguai que haviam fundado a COASI (Comité Obrero de Acción Sindical Independiente de Argentina). Eles criticaram a falta de liberdade do regime e solicitaram uma "bolsa de auxílio a líderes sindicais exilados". Ver: CARLOS, Newton. "Houve realmente um Congresso" In Tribuna da Imprensa, Rio de Janeiro, 20-21/12/1952, p. 12.

${ }^{460}$ LUNA, Felix. Perón y su tiempo. II - La comunidad organizada (1950-1952). Editorial Sudamericana, Buenos Aires, 1985,p. 298.
} 
Tribuna da Imprensa tripudiou a respeito da reunião de fundação, afirmando que teriam comparecido apenas "meia dúzia de gatos pingados". ${ }^{461} \mathrm{Na}$ lista de presentes nas primeiras reuniões figuraram pelo menos dois sindicalistas brasileiros. ${ }^{462}$ Não se sabe quantas entidades locais aderiram posteriormente. Em tom de orgulho, o jornal aduziu que aquele primeiro encontro fora cogitado para o Rio de Janeiro, mas o plano teria sido descartado após a percepção do tamanho do "vulto da onda antiperonista" no país. $^{463}$

Ideologicamente, a nova entidade se colocava em consonância com o projeto justicialista de manter equidistância dos "dois imperialismos" e de consolidar a Terceira Posição. A ATLAS foi apontada como mais um capítulo dos planos platinos de dominação da região. "O grande sonho de Perón é encampar o movimento sindical latino-americano e anular a Organização Interamericana do Trabalho [ORIT]", assegurou Newton Carlos. ${ }^{464}$ Nessa perspectiva, os "agregados obreros" argentinos estariam tentando cooptar sindicatos locais para a ATLAS, evitando, dessa forma, que eles se vinculassem à central ligada aos norte-americanos. De acordo com uma notícia não assinada publicada na Tribuna da Imprensa, Jango Goulart estaria "mancomunado" com o agregado obrero argentino para evitar o alinhamento à ORIT. A ação faria parte de um objetivo maior, o estabelecimento da "revolução dos pelegos". ${ }^{465}$

Embora não se possa assegurar o envolvimento do Ministro do Trabalho brasileiro nesse processo, Claudio Panella confirma que ao redor do continente os agregados trabalhistas foram fundamentais para a construção da ATLAS, por terem obtido a filiação de dezenas de sindicatos. ${ }^{466}$

Em menor escala, a Tribuna da Imprensa denunciou a aproximação entre a ATLAS (de tendência justicialista) e a CTAL (de tendência comunista) na gestação de uma "linha comum perono-comunista no plano continental". ${ }^{467}$ Como se verá, essa

\footnotetext{
461 CARLOS, Newton. “Os trabalhadores livres das Américas” In Tribuna da Imprensa, Rio de Janeiro, 12/12/1952, p. 12

${ }^{462}$ CARLOS, Newton. "Peronistas financiavam sindicatos brasileiros" In Tribuna da Imprensa, Rio de Janeiro, 20/6/1955, p. 8.

463 CARLOS, Newton. "Reação do governo uruguaio" In Tribuna da Imprensa, Rio de Janeiro. 24/10/1952, p. 12

${ }^{464}$ CARLOS, Newton. "Rede de infiltração na América Latina” In Tribuna da Imprensa, 25/09/1952, p. 12.

465 "Jango Goulart, aliado ao peronismo, dirige a campanha de "moralização"” In Tribuna da Imprensa, Rio de Janeiro, 25-26/10/1952, p. 1 e 2.

466 PANELLA, 1994, op. cit., p. 54-55.

467 “Intervenção peronista na política brasileira” In Tribuna da Imprensa, Rio de Janeiro, 21/8/1953, p. 5
} 
tentativa de apontar tais ideologias como semelhantes foi estratégia constante do diário e, especialmente, de Carlos Lacerda.

O que os meios de comunicação liberais-conservadores ignoravam, de modo deliberado ou não, é que os adidos operários norte-americanos também buscavam cooptar lideranças políticas e sindicais brasileiras. É o que defende em sua tese o historiador Eduardo José Afonso, que analisou os relatórios enviados por esses funcionários norte-americanos a partir de sua atuação do Brasil no período de 1943 a 1952. ${ }^{468}$ De acordo com ele, mais do que a coleta de dados e monitoramento, esses adidos faziam primordialmente um trabalho ligado à inteligência. ${ }^{469}$

Especialmente nos anos iniciais da Guerra Fria, interessava muito ao governo norte-americano barrar a expansão de ideias comunistas e de esquerda entre os trabalhadores sindicalizados. Desse ponto de vista, a atuação dos colegas argentinos e sua difusão da Terceira Posição argentina representavam uma ameaça. Isso justifica o acompanhamento atento dos passos da política justicialista e a luta silenciosa contra eles promovida pelo serviço de contra-inteligência de Washington.

Aparentemente, a atuação dos adidos operários norte-americanos foi mais reservada do que a dos argentinos. Além de não usarem a embaixada como centro de difusão de material de propaganda política, os convites para líderes brasileiros conhecerem os Estados Unidos geralmente partiam das centrais sindicais norteamericanas, e não da diplomacia diretamente. Documentos secretos consultados por Eduardo José Afonso mostram a enorme preocupação da chancelaria em ocultar que tais viagens eram financiadas diretamente pelo Estado norte-americano. ${ }^{470}$

Essa discrição talvez tenha colaborado para que, nas palavras de Afonso, a "livre circulação de representantes norte-americanos das centrais sindicais AFL e CIO, em círculos restritos do Palácio do Catete" ${ }^{471}$ chamasse bem menos atenção dos diários liberais-conservadores do que a atuação dos adidos justicialistas. Além disso, não se pode deixar de considerar, tendo em vista o contexto de bipolarização política mundial, o evidente alinhamento ideológico desses meios de comunicação em relação aos Estados Unidos.

\footnotetext{
468 AFONSO, Eduardo José. Para norte-americano ver. Adidos Trabalhistas e operários brasileiros (1943/1952). Tese de Doutorado (História Social). São Paulo: FFLCH/USP, 2011.

469 Ibidem, p.84.

${ }^{470}$ Ibidem, p. 131.

${ }^{471}$ Ibidem, p. 266.
} 
Por fim, no início de 1954 já havia notícias a respeito da falência da central sindical latino-americana idealizada por Perón devido a seu alto custo, difícil de ser financiado pelo governo platino em um momento de crise econômica. ${ }^{472}$ Ao longo dos anos, a ATLAS não conseguiu a adesão de grandes centrais sindicais do Brasil e do México, países com maior número de operários. Por meio da ação dos adidos obreros, houve a adesão de algumas entidades de outras nações da América Latina. No entanto, estas geralmente contavam com poucos filiados e eram organizações de classe bem menos estruturadas, fazendo com que as altas despesas recaíssem muito sobre a Argentina. Em um círculo vicioso, essa liderança argentina ampliava a desconfiança de que a ATLAS não passava de um instrumento de propaganda do justicialismo. A entidade deixou oficialmente de existir pouco depois da queda de Perón, embora já estivesse moribunda tempos antes. ${ }^{473}$

Quanto ao programa de agregados obreros, ele vinha sendo reduzido pelo ministro das Relações Exteriores, Jerônimo Remorino, após incidentes em outros países e conflitos com os tradicionais diplomatas de carreira. ${ }^{474}$ A iniciativa também foi finalizada após o golpe militar de 1955, com todos os representantes sendo convocados a retornar ao país.

Em relação à infiltração na imprensa local, pode-se citar a fundação em 1949 da Agência Latina de Notícias S.A., no Rio de Janeiro. Da ata de fundação da empresa constam acionistas como João Batista Lusardo e diversos banqueiros e industriais locais, que seriam comandados oficialmente pelo empresário e jornalista baiano Geraldo Rocha (1881-1959), dono do jornal vespertino carioca $O$ Mundo ${ }^{475}$ Em várias fontes do período, Rocha é apontado como amigo do presidente argentino. Um jornal paulistano getulista saudou a novidade como "uma grande organização brasileira, iniciativa de um grupo de capitalistas de alta visão que tiveram como objetivo principal estreitar laços de amizade que unem os povos latino-americanos". ${ }^{476}$

Apesar de pertencer oficialmente a empresários brasileiros, a Agência Latina foi provavelmente uma tentativa de Perón de reagir à violenta campanha que seu governo

\footnotetext{
472 CARLOS, Newton. "Caracas nada representa para os trabalhadores americanos" In Tribuna da Imprensa, 12/3/1954, p. 5.

${ }^{473}$ LUNA, 1985, op. cit., p. 296-300.

${ }^{474}$ Entre 1951 e 1955, 45\% deles tiveram seus postos fechados nas embaixadas e consulados sem que fossem indicados substitutos. Ver: PANELLA, 1994, op. cit., p. 56-57.

475 Diário Oficial da União (DOU) de 01/11/1949, seção 1, p. 44. Consulta on-line via site www.jusbrasil.com.br . Acesso em 18/11/2014.

476 "Instalada solenemente a Agência Latina de Notícias" In Jornal de Notícias. São Paulo, 10/06/1950, p. 2
} 
sofria por parte das agências de notícias tradicionais, bastante vinculadas ao ponto de vista da diplomacia norte-americana. Várias fontes bibliográficas indicam que a agência de notícias foi financiada e coordenada a partir da Casa Rosada. ${ }^{477}$

A imprensa conservadora brasileira não deixou o assunto passar em brancas nuvens. Logo em seu primeiríssimo número, Tribuna da Imprensa reprovou o surgimento de "uma agência de propaganda camuflada de noticiosa". Acusou a Agência Latina de ser financiada "mediante contribuições arrancadas dos industriais brasileiros que têm feito grandes negócios, especialmente de tecidos, com a Argentina". ${ }^{478}$ Ainda de acordo com o jornal, Geraldo Rocha estaria trabalhando "para que se implante o peronismo no Brasil". ${ }^{479}$ E, de forma mais explícita, denunciou: "A Agência Latina é o órgão de provocação jornalística de Perón no Brasil. Interessado, portanto, em dividir o Exército e provocar a desordem". ${ }^{480}$ Para o exilado argentino Rodriguez Araya, homens como Geraldo Rocha não passavam de "mercenários" ou "traficantes da pena". ${ }^{481}$

Um balaço da empresa publicado no Diário Oficial dava conta de que em 1953 já havia sucursais na Argentina, Chile, Bolívia, Equador, Colômbia, Cuba e México. ${ }^{482}$ O informe, no entanto, lamentou que a agência estivesse encontrando "compreensão e aceitação" bem maior em outros países do que no Brasil. ${ }^{483}$

Em outubro de 1955, documentos publicados no Diário Oficial informaram a "completa liquidação" da Agência Latina apenas duas semanas após a queda de Perón. A dissolução foi atribuída à "crise que se debate a imprensa continental". A iniciativa foi descrita como fruto da "aspiração patriótica de um grupo de brasileiros de boa vontade que procuravam se libertar da intervenção estrangeira em atos da vida interna dos países continentais". O texto encerra-se em tom esperançoso: "Dias virão, porém, em que esta iniciativa será retomada por outros patriotas, os quais assim colaborarão para o perfeito entendimento entre os países irmãos". ${ }^{484}$

\footnotetext{
${ }^{477}$ Ver: CANE, op.cit., p. 199; CISNEROS, op. cit., p. 379; SIRVEN, op. cit., p. 190-191.

${ }^{478}$ Rio, José do. “Coluna Vozes da Cidade” In Tribuna da Imprensa, Rio de Janeiro, 27/12/1949, p. 1.

479 "Exportadores de tecidos obrigados a financiar a propaganda de Perón" In Tribuna da Imprensa, Rio de Janeiro, 21/3/1950, p. 1.

${ }^{480}$ Coluna do DIP (O que está por trás das notícias dirigidas) In Tribuna da Imprensa, Rio de Janeiro, 18/11/1950, p. 1 .

481 “Mercenários peronistas” In Tribuna da Imprensa, Rio de Janeiro, 20-21/10/1951, p. 1.

482 Entre os correspondentes em vários pontos da América Latina, destaca-se o então desconhecido fotógrafo Ernesto "Che" Guevara, que trabalhava no México.

483 Diário Oficial da União (DOU) de 30/12/1953, Seção 1, p. 57. Consulta on-line via site www.jusbrasil.com.br . Acesso em 18/11/2014.

${ }^{484}$ Diário Oficial da União (DOU), 27/10/1955, Seção 1, p. 65. Consulta on-line via site www.jusbrasil.com.br . Acesso em 18/11/2014.
} 
Notícias assinadas pela Agência Latina foram encontradas em dois meios de comunicação brasileiros marcadamente peronófilos, $O$ Radical e Mundo Ilustrado. Ambos poderão ser pesquisados de forma mais detalhada no futuro.

Sabe-se que $O$ Radical foi um pequeno diário ligado aos sindicatos e voltado ao público operário. Dirigido por Georges Galvão, deputado federal pelo PTB, foi um dos representantes da chamada "imprensa trabalhista" ${ }^{485}$ Em suas páginas, nota-se vivo interesse em relação ao peronismo. Há, por exemplo, informes de jornalistas ${ }^{486}$ e sindicalistas ${ }^{487}$ brasileiros que foram visitar a Argentina com patrocínio do governo justicialista. Podem ser lidos também artigos de líderes operários expressando sua solidariedade em relação à luta de Perón contra seus inimigos políticos. ${ }^{488}$ Paralelos entre Vargas e Perón, também eram comuns: ao dar uma notícia sobre o aumento do salário mínimo por Getúlio, $O$ Radical estampou em sua primeira página: "Ele cumpre". ${ }^{489}$ A frase traz uma referência explícita ao slogan justicialista "Perón cumple, Eva dignifica". 490

Também a revista semanal Mundo Ilustrado transmitia visão bastante positiva do peronismo. De propriedade de Geraldo Rocha, esse magazine brasileiro publicou farto material iconográfico a respeito do governo justicialista. Além da profusão de fotografias, dezenas de editorais assinados pelo proprietário ajudaram a dar o tom profundamente laudatório que predominou desde o surgimento da revista (1953) até a derrubada de Perón (1955). Essas representações, muito ligadas à imagem dos descamisados que vivenciariam uma verdadeira revolução, parecem semelhantes ao que se vinculava na Argentina. Pesquisas futuras poderão verificar se esse meio de comunicação veiculou deliberadamente propaganda peronista no País.

\footnotetext{
$485 \mathrm{O}$ periódico foi bastante utilizado pelo historiador Jorge Ferreira. Ver: FERREIRA, Jorge. $O$ imaginário trabalhista: getulismo, PTB e cultura política popular (1945-1964). Rio de Janeiro, Civilização Brasileira, 2005.

486 "Convidados os jornalistas para o desfile do Dia da Lealdade" In O Radical, Rio de Janeiro, 15 de outubro de 1951, p. 8.

487 "Como os operários brasileiros viram as eleições argentinas" In O Radical, Rio de Janeiro, 13 de novembro de 1951, p. 8.

488 VIDIGAL, Gastão. "Estoy com ustedes". O Radical, Rio de Janeiro, 2 de outubro de 1951. Coluna "Movimento sindical", p. 6.

489 "Ele cumpre". O Radical, Rio de Janeiro, 1o. de novembro de 1951, p. 1.

490 CAPELATO, Maria Helena Rolim. Multidões em Cena: Propaganda Política no Varguismo e no Peronismo. 2a edição. São Paulo: Editora UNESP, 2008. p. 83.
} 


\subsection{A República sindicalista}

A imprensa já seguia os passos do deputado federal João Goulart bem antes de ele se tornar ministro. Desfrutando da amizade e da intimidade do presidente da República, são-borjense como ele, Jango possuía um gabinete no Palácio do Catete, onde agia como interlocutor privilegiado com líderes sindicais e trabalhadores. ${ }^{491}$ Ao se tornar presidente do diretório nacional do PTB, em abril de 1952, a vigilância dos antigetulistas em torno dele só aumentou.

Em novembro daquele ano, a Tribuna da Imprensa noticiou uma suposta aliança entre o líder sindical mexicano Vicente Lombardo Toledano (da CTAL, de tendência comunista) e o argentino José Espejo (secretário-geral da CGT peronista). E acrescentou: "Falta, agora, apenas, tornar-se pública a ligação com a camarilha sindical do Palácio do Catete, representada neste momento pelo notório João (“Jango") Goulart, o estancieiro milionário que agita as massas em favor das aventuras demagógicas". 492

A partir de 1953, a sustentabilidade política do governo piorou consideravelmente. A inflação corroía cada vez mais os salários. Em consequência, começaram a pulular mobilizações operárias que, em alguns casos, arrastaram multidões, como na greve dos 300 mil ocorrida no estado de São Paulo. Além disso, as tentativas de Vargas de cooptar a UDN mostraram-se pouco animadoras e acabaram por descontentar muitos dos antigos aliados. Tornava o quadro ainda mais nebuloso uma CPI que investigava o favorecimento do Banco do Brasil ao jornal varguista Última Hora. As investigações parlamentares acarretaram cinco meses de contínuas manchetes negativas em relação ao Poder Executivo.

Em junho, Vargas reagiu e iniciou uma reforma ministerial que, grosso modo, indicou novos nomes conservadores. Ele ousou, porém, ao entregar a pasta do Trabalho, Indústria e Comércio ao jovem Goulart, de apenas 34 anos. Seu antecessor, o também petebista José de Segadas Viana (1906-1991), havia angariado impopularidade entre os trabalhadores e sindicalistas por seus métodos autoritários, o que enfraqueceu uma das bases de sustentação do governo.

Em seu discurso de posse, Jango afirmou que seu compromisso seria principalmente com "o povo, no mais amplo sentido da expressão, e especialmente com

\footnotetext{
${ }^{491}$ FERREIRA, 2005, op. cit., p. 102.

492 "União sindical perono-comunista” In Tribuna da Imprensa, Rio de Janeiro, 11/11/1952, p. 1.
} 
o proletariado". ${ }^{493}$ Em outro pronunciamento, destacou a importância da união e mobilização dos trabalhadores e garantiu-lhes que o ministério sob sua gestão atuaria como uma trincheira da classe. ${ }^{494}$ Para os opositores, ele atuava como representante apenas dos trabalhadores, e não do trabalho, indústria e comércio.

As falas de Jango prenunciavam uma nova fase das relações entre o Estado e os sindicatos, marcada principalmente pela abertura ao diálogo e pela diminuição das medidas repressivas. De acordo com Jorge Ferreira, o político gaúcho aboliu em definitivo a exigência de atestados ideológicos para sindicalistas e diminuiu consideravelmente intervenções do ministério nessas entidades. ${ }^{495}$ Ações como essas garantiram maior aproximação e, até mesmo, alianças pontuais com líderes sindicais comunistas. Além disso, houve estímulo à fiscalização da legislação trabalhista e mediação de acordos que, além de darem fim a algumas das greves, garantiram aumentos salariais substanciais aos empregados de diferentes setores. Aos poucos, os sindicatos tornaram-se um ator político cada vez mais visível.

Ainda de acordo com Jorge Ferreira, o trabalhismo brasileiro buscou nesse momento atualizar seu programa, alinhando-se ideologicamente aos movimentos socialdemocratas europeus, que defendiam a criação e manutenção de um Estado de bemestar social que oferecesse ampla rede de proteção aos trabalhadores. O processo para atingi-lo, afirmou João Goulart, passava pela democracia e pelo respeito à Constituição. Muito presente no discurso petebista também estavam o anti-imperialismo e o nacionalismo, bastante em voga na América Latina do período. ${ }^{496}$

A atuação do novo ministro, além de robustecer as relações sindicais, fez dele um político muito popular. Assis Chateaubriand, em pronunciamento no Senado, chamou-o de ministro da Propaganda de Vargas. ${ }^{497}$ Era uma crítica que demonstrava o êxito de Jango. Em ofício datado de dezembro de 1953, a embaixada argentina no Rio de Janeiro informou: "Seu nome é mencionado cada dia com maior apoio do proletariado brasileiro como futuro candidato à Presidência da nação na eleição a realizar-se em 1954". 498

\footnotetext{
493 Apud FERREIRA, 2005, op. cit., p. 107.

${ }^{494}$ Apud FERREIRA, 2005, op. cit., p. 109.

${ }^{495}$ FERREIRA, 2005, op. cit., p. 107.

${ }^{496}$ Ibidem, p. 121-122.

497 “Jango, ministro da propaganda" In Tribuna da Imprensa, Rio de Janeiro, 20/2/1954, p. 2.

498 Apud ALMEIDA, 2005, op. cit, p. 115.
} 
O sucesso, entretanto, gerou cólera proporcional por parte dos liberaisconservadores. ${ }^{499}$ Jango foi diretamente responsabilizado pelo considerável aumento de greves no segundo semestre de 1953. Além disso, após sua nomeação o conflito com a UDN intensificou-se sobremaneira e os udenistas ampliaram seus contatos com as Forças Armadas. De acordo com Jorge Ferreira, “a opção pelo golpe, que amadurecia desde a posse de Vargas, tornou-se a partir de então irreversível". 500

Para Carlos Lacerda, a indicação de Jango para o ministério era mais um argumento a confirmar a tese que ele vinha tenazmente difundindo: Getúlio Vargas preparava silenciosamente um novo regime discricionário. Udenistas, de modo geral, o tinham como um "inimigo irreconciliável da democracia". ${ }^{01}$ Antes das eleições, Lacerda já assegurava que a candidatura do político gaúcho não passava, em realidade, de uma conspiração. Na ocasião, fustigou: “Os ditadores produzem ditadura com a naturalidade e, por assim dizer, o grau de fatalidade com que as galinhas põem ovos. Que há de o sr. Getúlio Vargas pôr senão ditadura?". ${ }^{02}$ Com base nessa lógica, a criação de um governo de tipo peronista parecia um desdobramento natural:

[...] com uma parte da população, na sua maior parte composta dos elementos politicamente menos esclarecidos e economicamente mais necessitados, a fazer pressão e exercer uma espécie de ditadura sobre o restante do povo, ele [Vargas] conta chegar ao poder para peronizar o Brasil. ${ }^{503}$

Lacerda, que nos dizeres de Hélio Jaguaribe possuía "visão policial da História" ${ }^{504}$, enxergava a preparação de um golpe em qualquer atitude do governo: "Ele [Vargas] se serve da lei como de um biombo. Por baixo e por cima desse frágil tapume vê-se o que ele anda a fazer". ${ }^{505}$ Nesse sentido, as crises políticas que se acumulavam não passariam de uma estratégia previamente orquestrada. Nas palavras do jornalista fluminense, "o Governo não governa porque não quer, porque não sabe, porque não

\footnotetext{
${ }^{499}$ Novamente, a situação ficou registrada na correspondência da diplomacia argentina. Em um ofício, pode-se ler: " $[\ldots]$ em nenhum momento da história política do Brasil, nenhum dirigente deve ter sofrido uma perseguição tão permanente e geral como a que tem acontecido contra o presidente do PTB" (Apud ALMEIDA, op. cit., p. 246).

${ }^{500}$ FERREIRA, 2005, op. cit., p. 125.

501 "Lançamento oficial do peronismo no Brasil - Jango num grito em Marília" In Tribuna da Imprensa, Rio de Janeiro, 29/7/1953, p. 1 e 2.

${ }_{502}^{502}$ LACERDA, Carlos. “A conspiração" In Tribuna da Imprensa, Rio de Janeiro, 20/06/1950, p. 4.

503 Ibidem.

${ }^{504}$ Apud BENEVIDES, op. cit., p. 156.

${ }^{505}$ LACERDA, Carlos. "Por Pernambuco e Minas, pela federação" In Tribuna da Imprensa, Rio de Janeiro, 16/6/1954, p. 4.
} 
deseja governar com liberdade, com a lei e ordem legitimamente instituídas. O que ele quer é arbítrio, é confusão, é movimento". 506

A existência de um inimigo (Vargas) que agiria nas sombras legitimava que a mesma estratégia fosse colocada em prática por aqueles que se arrogavam os verdadeiros democratas. Assim, ao justificar a necessidade de intervenção das Forças Armadas, Lacerda e outros astutamente conclamavam os "grupos esclarecidos" não para um golpe, mas para o que chamavam de um "contragolpe", que deporia um governo tido como inimigo da liberdade e prestes a "trair o país". Para reforçar essa tese, insistia-se no recente passado autoritário de Vargas, que ainda não havia se apagado da memória de muitos, especialmente dos jornalistas.

Lacerda assegurava que desta vez Vargas não copiaria os passos tradicionais de líderes despóticos que haviam sucumbido na Segunda Guerra, como Hitler e Mussolini. Ele optaria por uma ditadura com aparência democrática e com respeito dissimulado pelas liberdades individuais. Nesse sentido, Perón era apontado com um modelo, pois teria aperfeiçoado os métodos autoritários elaborados pelo fundador do Estado Novo. Em sua acepção, o governo estaria "dominado pela fascinação que sobre o velho mestre [Vargas] exerce o discípulo que o superou [Perón]". ${ }^{507}$ Em outra ocasião, Lacerda destacou:

[...] ninguém pode admirar-se se o sr. Getúlio Vargas adotar, desta vez, a fórmula de Perón: ditadura com Congresso aberto. Um Congresso acuado, ressequido, miserável, como esse que na Argentina, resgatada a sua culpa apenas pelos bravos resistentes da minoria, rasteja aos pés de Perón e de sua mulher, desonrando o povo argentino. ${ }^{508}$

Para estabelecer o regime discricionário, o presidente brasileiro e os trabalhistas adotariam duas estratégias principais: o fortalecimento dos sindicatos e a manipulação das eleições. Como outros liberais, Lacerda tinha grandes reservas em relação a essas associações de classe. Segundo ele, "o sindicato não é sempre e necessariamente arma de libertação e de melhoria. Pode ser, e frequentemente tem sido, arma de mistificação do trabalhador e de opressão da sociedade. Tal é a sua função na Argentina de Perón,

\footnotetext{
506 LACERDA, Carlos. "O governo prepara a traição" In Tribuna da Imprensa, Rio de Janeiro, 12/6/1951, p. 4.

${ }^{507}$ LACERDA, Carlos. "La Prensa e o interesse do Brasil". Tribuna da Imprensa, Rio de Janeiro, 15 de março de 1951, p. 4.

${ }^{508}$ LACERDA, Carlos. "Vargas desmente Vargas" In Tribuna da Imprensa, Rio de Janeiro, 19 de março de 1951, p. 4.
} 
como na Rússia de Stálin". ${ }^{509}$ Ao alentá-los, Getúlio Vargas criaria as bases para uma nova configuração política, marcada pelo enfraquecimento dos partidos.

Lacerda chamou essa suposta estratégia de "golpe peronista, no estilo boliviano" e aduziu: "Não se trata do fechamento do Congresso, como foi feito em 1937 e, sim, da sua dominação pela massa de manobra de um sindicalismo dirigido por 'pelegos', visando reformar a Constituição e estabelecer uma ditadura no país". ${ }^{510}$ Fortalecidos, os trabalhistas alterariam a Constituição e garantiriam a possibilidade de reeleições ilimitadas, como já acontecia na Argentina. Lacerda argumentou que esse plano dissimulado passaria também pelo "desarmamento sub-reptício das forças militares e a organização de uma Confederação Geral do Trabalho, em moldes totalitários, para o enquadramento dos trabalhadores, sob comando único". 511 Sem partidos fortes e com os sindicatos controlados pelo Estado via central única, surgiria uma nova ordem autoritária, na qual seria possível "jogar os trabalhadores contra o resto da Nação". Essas seriam as bases do futuro regime discricionário, a que ele chamou, em certa ocasião, de "sindicalismo totalitário". 512

Dias depois de Lacerda usar essa expressão, uma charge de Hilde Weber buscou traduzir em termos imagéticos aquelas ideias (figura 14).

\footnotetext{
${ }^{509}$ LACERDA, Carlos. "Vida sindical” In Tribuna da Imprensa, Rio de Janeiro, 11/12/1952, p. 4.

510 ““'Última Hora” integrada no esquema do golpe peronista que Jango Goulart prepara” In Tribuna da Imprensa, Rio de Janeiro, 8/7/1953, p. 1 e 2.

511 LACERDA, Carlos. "Joãozinho Boa Pinta, demagogo de cabaré” In Tribuna da Imprensa, Rio de Janeiro, 5/8/1953, p. 4.

512 LACERDA, Carlos. “O sindicalismo totalitário" In Tribuna da Imprensa, Rio de Janeiro, 4 de maio de 1951, p. 4.
} 


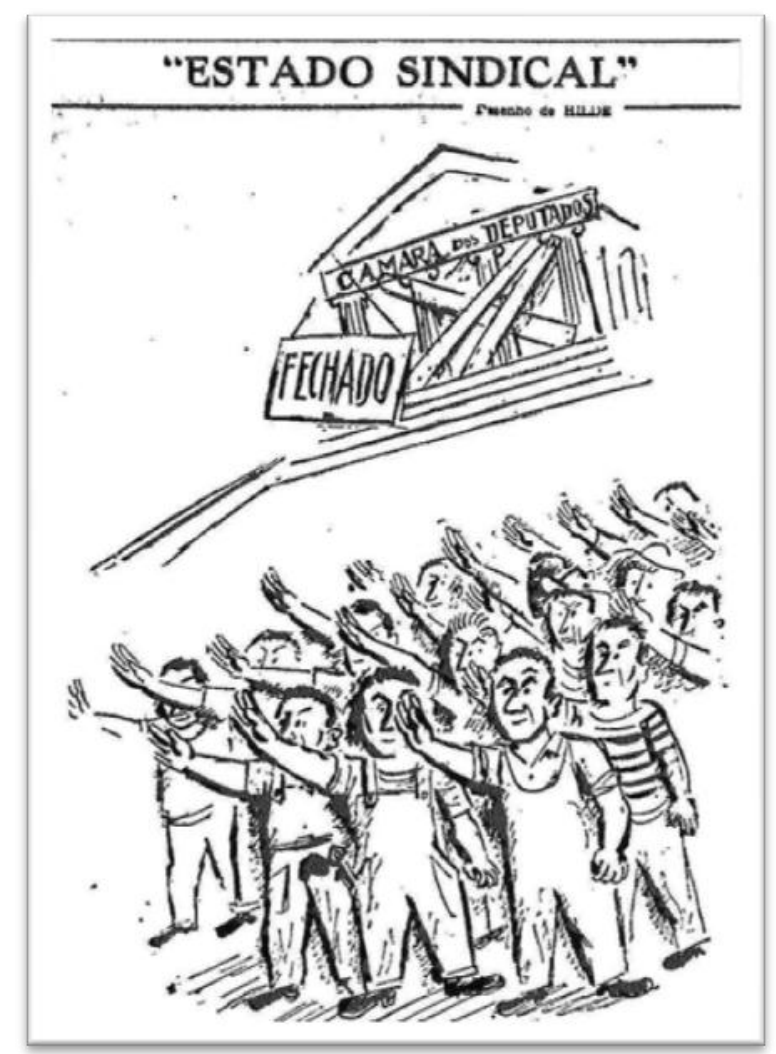

Figura 14 - Hilde. Tribuna da Imprensa, 08/05/1951.

Anos depois, saiu da boca de um aliado do governo, o sindicalista petebista Wilson de Barros Leal, outra expressão que se mostraria bem mais eficaz para ilustrar as ideias disseminadas pela oposição: "república sindicalista". Em 1953, em um discurso sobre as eleições vindouras, Leal afirmou que os trabalhadores em breve "poderiam eleger um parlamento que representasse seus interesses de classe, constituindo, assim, uma 'República sindicalista". ${ }^{513}$ Imediatamente, o termo passou a ser explorado pela imprensa e por políticos de oposição. Aparentemente, ele traduzia de forma muito eficiente a ideia de um governo de fachada democrática baseado nos sindicatos. A partir de então, essa expressão passou a imputar aos petebistas um projeto não democrático.

Para os udenistas, os trabalhistas estariam se articulando silenciosamente também para obter a maioria do Congresso e garantir a execução dos seus planos secretos. Explica Lacerda:

O golpe constitucional da República Sindicalista é muito simples: cabe aos titeriteiros fazer, nas eleições do ano que vem, a maioria parlamentar. Depois, com esta sonhada maioria, reformar a Constituição, para que seja permitida a

${ }^{513}$ FERREIRA, 2005, op. cit., p. 128. 
reeleição, pelo Congresso, do titeriteiro-mor. E a continuidade estará assegurada $[\ldots]^{514}$

Lacerda chamou esse suposto plano tirânico de "golpe legal", ou "o golpe da mudança da Constituição por uma maioria ditatorial, como se fez na Argentina de Perón". 515 Em um raciocínio tortuoso, asseverou que era necessário usar a força para salvar a democracia das mãos de uma "maioria autoritária". Como se pode notar, há nesse jogo de palavras um evidente desapreço às regras básicas do sistema democrático. Com efeito, ele e outros udenistas pareciam imbuídos de certo sentido messiânico que enxergava nos adversários conspiradores imorais a serem combatidos de todas as formas possíveis. Nessa lógica, a imoralidade das ações dos adversários justificava atitudes incompatíveis com a própria democracia, como o uso da força no lugar dos argumentos.

Durante o período em que Jango foi ministro não faltaram as costumeiras ofensas pessoais. Ele, por exemplo, foi chamado de "fanfarrão" e tido como dono de uma "lábia de malandro jovem". ${ }^{516}$ Em referência à sua notória vida boêmia, Lacerda deu a um de seus editoriais o título "Joãozinho Boa Pinta, demagogo de cabaré". No texto, atacou:

\footnotetext{
Joãozinho Boa Pinta deve sair do ministério e voltar ao cabaré - que é a sua universidade, a sua caserna e o seu santuário. O cabaré o espera com acompanhamento de "bandoneon" [sic].

O Brasil não está mais em idade de aturar as impertinências de um irresponsável.

Ser ministro não é o mesmo que dançar tango. ${ }^{517}$
}

Para parte significativa da oposição, Jango, que já expressara publicamente sua admiração pelo chefe da Casa Rosada, era um novo Perón, pois estaria se fortalecendo no Ministério do Trabalho, com o apoio dos sindicatos e dos comunistas, supostamente como fizera o presidente argentino.

Os ataques se intensificaram a partir de agosto de 1953, quando o Congresso Brasileiro de Previdência Social reuniu mil e duzentos líderes sindicais no Rio de Janeiro. Ali, eles aceitaram a proposta do Ministério do Trabalho de participação nas

\footnotetext{
${ }^{514}$ LACERDA, Carlos. “A República de Jango está em marcha” In Tribuna da Imprensa, Rio de Janeiro, 7/10/1953, p. 4.

${ }^{515}$ LACERDA, Carlos. "Por Pernambuco e Minas, pela federação" In Tribuna da Imprensa, Rio de Janeiro, 16/6/1945, p. 4.

${ }^{516}$ LACERDA, Carlos. "Joãozinho Boa Pinta, demagogo de cabaré" In Tribuna da Imprensa, Rio de Janeiro, 5/8/1953, p. 4.

${ }^{517}$ Ibidem.
} 
autarquias que compunham a Previdência. A medida permitia a participação desses militantes sindicais em setores-chave da administração e colocava à disposição deles muitos cargos e recursos públicos. ${ }^{518}$

Esse evento foi o estopim para uma série de boatos publicados em diários como Tribuna da Imprensa, Correio da Manhã e O Estado de S. Paulo, que davam conta de que aquela ampla mobilização sindical visava estabelecer um golpe peronista. Naquele momento, os parlamentares udenistas fomentavam e tinham sua ação fomentada por essas notícias desencontradas. O presidente do partido, Odilon Braga, por exemplo, advertiu: "Teremos dentro em breve, no Brasil, um governo de tipo peronista, ou, por outra, um Estado Novo instituído por processos sorrateiros, sem golpe declarado, se não organizarmos a resistência". ${ }^{519}$ Os desmentidos do governo não foram suficientes para diminuir a atmosfera de radicalização. ${ }^{520}$

Uma imagem publicada na primeira página da edição da Tribuna da Imprensa de 8-9 de agosto de 1953 buscou representar o "esquema do golpe peronista" na visão de grupos da oposição. A legenda informava:

O ESCÂNDALO da 'Última Hora' tem relações profundas com o plano do golpe sindicalista, tramado por Jango Goulart. O cliché reproduz o gráfico publicado pelo 'Correio do Dia' de Belo Horizonte, onde aparecem, detalhadas, as ligações dos golpistas Wainer e Jango, bem como os demais responsáveis e as organizações das quais se tem servido para pôr em marcha o plano agora desmascarado pela imprensa livre. ${ }^{521}$

\footnotetext{
${ }^{518}$ FERREIRA, 2005, op. cit., p. 111.

519 “Odilon Braga adverte: Governo de tipo peronista em breve no Brasil” In Tribuna da Imprensa, Rio de Janeiro, 24/11/1953, p. 1 e 4.

${ }^{520}$ NETO, Lira. Getúlio: Da volta pela consagração popular ao suicídio (1945-1954). 1 ${ }^{\text {a }}$. edição, São Paulo, Companhia das Letras, 2014, p. 253-255.

521 “Esquema do golpe peronista” In Tribuna da Imprensa, Rio de Janeiro, 8-9/8/1953, p.1.
} 


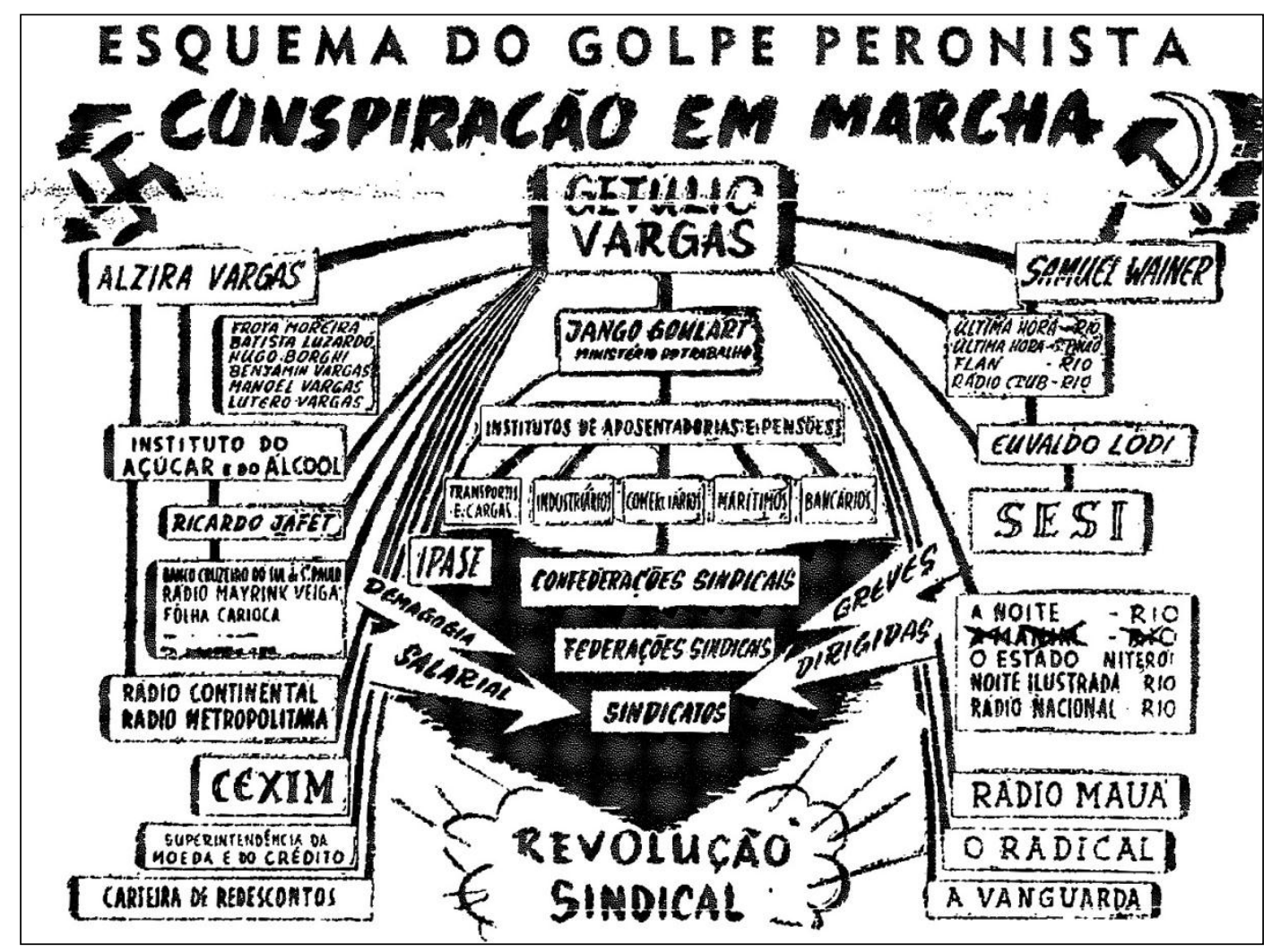

Figura 15 - "Esquema do golpe peronista" In Tribuna da Imprensa, Rio de Janeiro, 8-9/8/1953, p.1.

Como se pode observar, ladeiam o nome de Getúlio Vargas: Samuel Wainer, proprietário do jornal governista Última Hora, e Alzira Vargas, sua filha e principal assessora política, que segundo Lacerda estaria "praticando para Eva Perón”. ${ }^{522}$ Abaixo deles, há múltiplos nomes de pessoas, instituições estatais e privadas e meios de comunicação simpáticos ao governo. Alguns estão interligados e mostram entidades controladas ou influenciadas pelos indivíduos apontados. É o caso, por exemplo, do empresário Euvaldo Lodi (1896-1956), que, junto com Ricardo Jafet (1907-1958), era tido como um dos principais financiadores da campanha de $\operatorname{Vargas}^{523}$ e do grupo de comunicação Última Hora. ${ }^{524}$ Lodi, que fora o primeiro presidente da Confederação Nacional das Indústrias (CNI), atuou também como um dos fundadores e diretores do Serviço Social da Indústria (SESI). Daí a estranha inclusão dessa entidade no organograma golpista.

Na parte central, destaca-se logo abaixo do presidente o ministro do Trabalho, João Goulart, que teria sob seu controle os institutos de aposentadorias e pensões de

\footnotetext{
522 LACERDA, Carlos. "Brasil, país sem política exterior" In Tribuna da Imprensa, Rio de Janeiro, 26/10/1951, p. 4 e 5.

${ }^{523}$ NETO, op. cit., p. 193.

${ }^{524}$ Este era responsável pelos dois jornais de mesmo nome na capital federal e em São Paulo, pela revista Flan e pela rádio Clube. Ver: Ibidem, p. 222.
} 
diversas categorias profissionais (transporte e cargas, industriários, comerciários, marítimos, bancários etc.) e o Instituto de Previdência e Assistência dos Servidores do Estado (IPASE). À época, a previdência social era descentralizada, não existindo um órgão único como o atual Instituto Nacional do Seguro Social (INSS).

Muitos desses institutos mostrados na imagem tinham sido criados durante a Era Vargas e suas respectivas presidências eram exercidas por pessoas indicadas pelo Governo Federal. Quando, no Congresso Brasileiro de Previdência Social, de agosto de 1953, Jango convidou os sindicalistas a participarem mais ativamente da administração desses órgãos, a oposição denunciou o gesto como parte de um projeto que visava fortalecer os sindicatos e aproximá-los do governo. Como mostra a parte de baixo da imagem, para os grupos antivarguistas, Jango, apoiando-se e sendo apoiado pelos sindicatos, estaria produzindo "greves dirigidas" e praticando "demagogia salarial", que preparariam o clima para a futura "revolução sindical".

Convém refletir também sobre a "salada ideológica" evidente na imagem, com destaques ao nazismo e ao comunismo, indicados pelas insígnias na parte superior. A respeito do nazismo, a oposição gostava de lembrar a hesitação de Vargas em apoiar os Estados Unidos durante a Segunda Guerra e a postura germanófila de seus ministros militares durante o Estado Novo.

Soma-se a isso a ideia de que naqueles anos o presidente estaria discretamente em aliança com os comunistas brasileiros, proscritos desde 1947. Nesse sentido, o senador Hamilton Nogueira atacou Vargas no plenário em 1954 por ser leniente com estes:

Em desespero de causa, o presidente da República inscreve-se na linha comuno-peronista, namorando toda onda trabalhista que se coloca no sentido da destruição dos alicerces da verdadeira democracia. Não quer irritar os comunistas, a fim de poder usá-los quando necessitar de agitações para conservar a faixa presidencial. ${ }^{525}$

Lacerda apontava insistentemente o peronismo como um regime em aliança profunda com o Cominform. Em 1951, em editorial intitulado "O verdadeiro caráter do movimento peronista", denunciou a presença e atuação ativa de diversos políticos de formação marxista no governo platino. ${ }^{526}$ Para comprovar essa entranhada ligação, apresentou longos trechos de um artigo apologético ao justicialismo escrito pelo ex-

\footnotetext{
525 “Getúlio na linha comuno-peronista” In Tribuna da Imprensa, Rio de Janeiro, 10/6/1954, p. 2.

${ }^{526}$ LACERDA, Carlos. "O verdadeiro caráter do movimento peronista" In Tribuna da Imprensa, Rio de Janeiro, 23/10/1951, p. 4.
} 
militante comunista argentino Isaac Lebenson, tido como "agente de ligação entre a Rússia e a revolução de Perón em escala continental". 527

Profundamente alinhado aos Estados Unidos, Lacerda temia que o justicialismo acabasse sendo um movimento preparatório para futuras revoluções comunistas no continente. Para ele, o artigo de Lebenson havia revelado que "a revolução peronista é o tipo de revolução compatível com as condições dos países semicoloniais. É o comunismo de tipo semicolonial [...]". ${ }^{528}$ Segundo Lacerda, o texto de Lebenson seria prova documental do "caráter e os objetivos dessa aliança [com os soviéticos], pela qual se ameaça diretamente a unidade, a paz e a liberdade no continente americano". ${ }^{529}$ Semanas depois, uma charge de Hilde denunciou a influência de Stálin sobre o governo platino (figura 16).

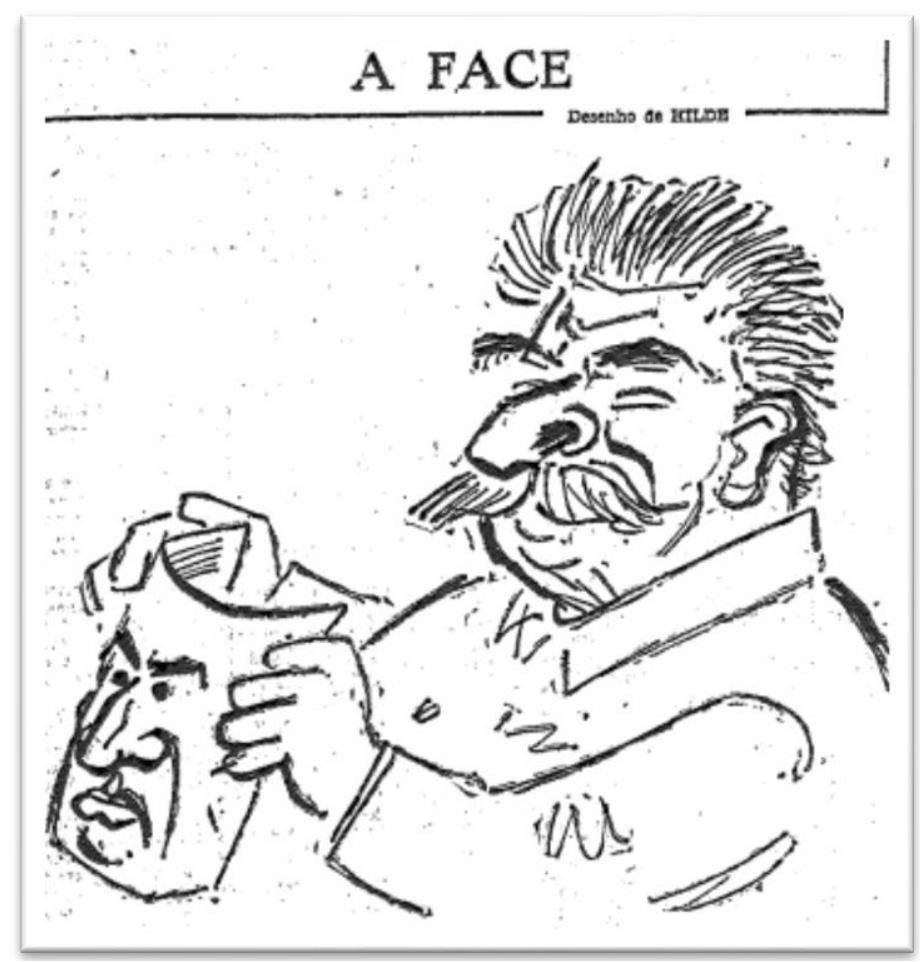

Figura 16. HILDE. Tribuna da Imprensa, 10-11/11/1951, p. 4.

A perspectiva de Lacerda era compartilhada por alguns grupos políticos da Argentina, que criticavam o governo por voltar-se cada vez mais à esquerda. Também em 1951, a Tribuna da Imprensa traduziu e veiculou um manifesto de democratas-

\footnotetext{
${ }^{527}$ LACERDA, Carlos. "União entre Perón e a Rússia" In Tribuna da Imprensa, Rio de Janeiro, 24/10/1951, p. 4.

${ }^{528}$ LACERDA, Carlos. "O verdadeiro caráter do movimento peronista" In Tribuna da Imprensa, Rio de Janeiro, 23/10/1951, p. 4.

${ }^{529}$ LACERDA, Carlos. "União entre Perón e a Rússia" In Tribuna da Imprensa, Rio de Janeiro, 24/10/1951, p. 4.
} 
cristãos daquele país que recriminava a aproximação do peronismo com um grupo supostamente comunista liderado por Rodolfo Puiggrós, expulso do Partido Comunista Argentino (PCA) em 1947. Esse conjunto de pessoas estaria ganhando cada vez mais espaço dentro do regime e apoiando-o entusiasticamente por vê-lo como "antesala do comunismo". Para os democratas cristãos argentinos, seu fortalecimento indicaria que “o próximo governo de Perón vai entrar resolutamente no comunismo ideológico". O texto previa ainda a ampliação da propaganda de cunho marxista e dos conflitos com a Igreja Católica e o Exército nos anos seguintes. E fustigava:

Sob a capa do "justicialismo", está-se introduzindo em nosso país o comunismo. Pode-se demonstrar isto muito facilmente, seja através dos discursos do general Perón, seja através das medidas governamentais no que se refere à organização econômica do país na base do capitalismo de Estado com a intervenção da C.G.T. ${ }^{530}$

Tanto no Brasil quanto na Argentina a caracterização do peronismo como uma variação do comunismo fortaleceu-se bastante a partir de 1953, quando se ampliaram os conflitos com a Igreja Católica e os acordos comerciais entre Buenos Aires e o governo moscovita. Nesse período, Lacerda assegurou que o peronismo possuía "nítida influência nazi-comunista" 531 e definiu o presidente platino como um "misto de funâmbulo grotesco e de sinistro ambicioso, filho de Juan Manuel Rosas e Josef Stálin". 532 Em suas palavras, a Rússia havia tomado o poder na Argentina por procuração. ${ }^{533}$

Malgrado a Tribuna da Imprensa e outros meios de comunicação vissem o Partido Comunista Argentino (PCA) como aliado fiel do peronismo, essa relação foi muito mais complexa e conflituosa do que a apresentada ao público. De acordo com depoimentos recolhidos pelo historiador argentino Marcelo Fonticelli, milhares de membros da agremiação foram presos após o golpe dado pelo GOU em $1943 .{ }^{534}$ Além disso, nos discursos do período em que era secretário do Trabalho, Perón criticava constantemente comunistas e socialistas e exortava a classe trabalhadora a banir dos sindicatos os militantes dessas organizações. ${ }^{535}$ Tal qual Vargas, costumava lembrar aos

\footnotetext{
530 “Aliança entre Perón e a Rússia” In Tribuna da Imprensa, Rio de Janeiro, 9/11/1951, p. 9.

${ }^{531}$ LACERDA, Carlos. "O dever dos brasileiros na América" In Tribuna da Imprensa, Rio de Janeiro, 8/5/1953, p. 4.

532 Ibidem.

533 LACERDA, Carlos. "Apaziguamento e legalismo de Chambelain a Sobral Pinto" In Tribuna da Imprensa, Rio de Janeiro, 1/9/1955, p. 4.

${ }^{534}$ FONTICELLI, Marcelo; PANELLA, Claudio. La prensa de izquierda y el peronismo (1943-1949). Socialistas y comunistas frente a Perón. $1^{\text {a }}$ Ed., La Plata, Universid Nacional de La Plata, 2007, p. 88-89. ${ }^{535}$ Ibidem, p. 145.
} 
empresários que as medidas de cunho social tomadas pelo Estado eram a melhor forma de evitar a repetição dos acontecimentos russos de 1917.

Compreende-se, dessa forma, por que o PCA fez inicialmente oposição ferrenha ao novo regime e caracterizou-o como nazifascista. Em consonância com tal posição, os acontecimentos de 17 de outubro de 1945 ("Dia da Lealdade", na perspectiva justicialista) foram duramente criticados pelos jornais comunistas. Nas eleições de 1946, estes apoiaram abertamente a União Democrática, ou seja, a chapa oposta à do coronel. ${ }^{536}$ Durante a campanha presidencial, a Igreja Católica chegou a recomendar o voto em Perón porque era o "candidato do governo que havia perseguido os comunistas e estabelecido o ensino religioso". 537

No entanto, após a derrota nas urnas, o PCA reorientou sua posição, abandonou as críticas sistemáticas e reconheceu a legalidade do novo governo. A classe operária, afinal, estava, em sua maioria, ao lado de Perón. A partir daí, suas posições políticas oscilaram conforme o tema e o momento. Em 1947, foram definidas por eles próprios como sendo de "apoio crítico" ao governo. ${ }^{538}$ Grosso modo, a agremiação também reconstruiu sua política sindical por meio da reacomodação, e do não enfretamento com as novas lideranças sindicais peronistas. ${ }^{539}$ Buscou acompanhar de perto a classe trabalhadora e, quando possível, denunciar o paternalismo, a demagogia e as contradições do heterogêneo movimento justicialista. ${ }^{540}$

Colaborou para essa mudança de postura do PCA a retomada das relações diplomáticas entre Buenos Aires e Moscou a partir da posse do novo presidente, em junho de 1946. Embora anticomunista, Perón sabia que a União Soviética era um dos protagonistas do novo cenário mundial e que, após a guerra, estava sedenta por alimentos. Após anos de hesitação do governo platino, foi finalmente celebrado em 1953 um acordo comercial que ampliou substancialmente as trocas comerciais entre os dois países. ${ }^{541}$

\footnotetext{
${ }^{536}$ Ibidem, p. 106.

${ }^{537}$ TORRE, op. cit., p. 34.

538 SPINELLI, María Estela. Los vencedores vencidos: el antiperonismo y la revolución libertadora. $1^{\mathrm{a}}$. edição, Buenos Aires, Biblos, 2005, p. 244.

539 VÁZQUEZ, Pablo Adrián. “Argentina y URSS. Relaciones comerciales y culturales durante los gobiernos de Perón” In Actas del Primer Congreso de estudios sobre el peronismo: la primera década. Mar del Plata, Noviembre de 2008. Disponível on-line http://redesperonismo.com.ar/archivos/CD1/EPP/vazquez.pdf . Acesso em 12/12/2014.

${ }^{540}$ FONTICELLI, op. cit., p. 146.

${ }^{541}$ CAVLAK, op. cit., p. 184.
} 
À época dessa aproximação econômica, um artigo não assinado na Tribuna $d a$ Imprensa vaticinava: "Se o ditador [Perón] não for obrigado a deixar seu cargo, a Argentina será brevemente a primeira república de democracia popular da América do Sul, contribuindo, junto com a Guatemala, à bolchevização de um mundo livre". ${ }^{542}$

O que não se lia nesses periódicos brasileiros é que, apesar do apoio em questões pontuais, as relações entre o peronismo e os comunistas locais foram bem mais complexas, como mostram diversos episódios. No final dos anos de 1940, o aumento das greves levou Perón a apontar um complot comunista como responsável por sabotar a política econômica. ${ }^{543}$ Em 1950, o jornal comunista La Hora foi empastelado, como tantos outros periódicos opositores. ${ }^{544}$ No ano seguinte, o sequestro ilegal e tortura pela polícia do estudante universitário comunista Ernesto Mario Bravo ganhou ampla repercussão, sendo denunciado inclusive pela revista $O$ Cruzeiro, que, convenientemente, omitiu a filiação política dos torturado e definiu-o apenas como "um estudante de reputação brilhante". 545

De outro lado, não se pode negar que o justicialismo atraiu correligionários do PCA, o que provocou, em alguns momentos, rachaduras em sua unidade e disciplina. Em certas ocasiões, militantes comunistas de destaque defenderam aproximação com o peronismo e acabaram expulsos, caso de Rodolfo Puiggrós e de Juan José Real.

Ainda assim, durante a longa crise que culminou no fim do primeiro peronismo, o governo argentino considerou os comunistas inimigos em potencial. Após a procissão de Corpus Christi realizada em Buenos Aires em 1955 terminar em saques e ataques a igrejas católicas, Perón eximiu seus apoiadores e culpou justamente os comunistas por aqueles atos violentos. ${ }^{546}$

A tese da infiltração comunista no governo justicialista, difundida por Lacerda e outros, deliberadamente ignorava isso. Ao associar os dois grupos políticos, objetivavase utilizar as imagens do imaginário anticomunista difundidas há décadas para atacar o regime argentino. Na lógica conservadora, eles se assemelhariam em alguma medida. A busca pela aproximação ideológica de dois inimigos que eram substancialmente

\footnotetext{
542 "Perón, discípulo de Moscou, apoia os comunistas" In Tribuna da Imprensa, Rio de Janeiro, 910/5/1953, p. 5.

${ }^{543}$ DOYON, Louise. La formación del sindicalismo peronista Juan Carlos Torre (dir.) Nueva Historia Argentina. Los años peronistas (1943-1955). Buenos Aires, Sudamericana, 2002, Tomo VIII, p. 377.

${ }^{544}$ FONTICELLI, op. cit., p. 88.

${ }_{545}^{5}$ CARIDE, Alberto. "O martírio de Mário Bravo" In O Cruzeiro, Rio de Janeiro, 27/09/1952, p. 60.

${ }^{546}$ CAVLAK, op. cit., p. 193.
} 
diferentes potencializava os efeitos dos ataques, ainda que simplificassem fortemente a realidade.

\section{4 "Perón cumple, pero Vargas no dignifica"}

A partir do início nos anos de 1950, Perón passou a insistir em seus discursos em um amplo acordo econômico envolvendo Argentina, Brasil e Chile. Tratava-se de uma proposta nova para um continente pouco afeito à ideia de união aduaneira entre nações soberanas. Astutamente, o mandatário da Casa Rosada chamou a iniciativa de Pacto $A B C$, referência à proposta de mesmo nome feita pelo Barão do Rio Branco no início do século. Eram, no entanto, projetos diferentes.

A partir de 1910, a diplomacia argentina, sob o governo de Roque Sáenz Peña, buscou aproximação com o vizinho lusófono. O presidente platino, em visita ao Rio de Janeiro, chegou a afirmar: "Todo nos une, nada nos separa". ${ }^{547} \mathrm{O}$ resultado concreto dessa fase de colaboração mais estreita apareceu em 1915, quando Argentina, Brasil e Chile assinaram o Tratado de Não Agressão, Consulta e Arbitragem, que ficou conhecido como Tratado (ou Pacto) do ABC.

Ao contrário das leituras feitas pelo peronismo, esse tratado não tinha caráter de aliança militar ou econômica e tampouco estabelecia a formação de um bloco para atuação diplomática conjunta. De acordo com Iuri Cavlak, tratava-se apenas de um primeiro passo que criava um foro regional para mediar conflitos e garantir a paz entre os três países. ${ }^{548}$ Estabelecia que as pendências que "não pudessem ser resolvidas por via diplomática ou por arbitragem teriam de ser submetidas à investigação e ao informe de uma comissão permanente, antes de qualquer abertura de hostilidades". ${ }^{549}$

Embora não contivesse cláusulas comerciais, supunha-se que o Tratado do $A B C$ facilitaria o futuro entrosamento econômico entre os participantes, mediante o estabelecimento de concessões recíprocas. Questões políticas internas, porém, impediram que ele fosse ratificado pelo Congresso argentino e vigorasse. De acordo com Moniz Bandeira, a imprensa norte-americana e de outros países da América Latina tampouco o viam com bons olhos. ${ }^{550}$

\footnotetext{
${ }^{547}$ BANDEIRA, op. cit., p. 127.

${ }^{548}$ CAVLAK, op. cit., p. 199-200.

${ }^{549}$ BANDEIRA, op. cit., p. 133.

${ }^{550}$ Idem.
} 
Mais de quatro décadas depois, em 1951, O Cruzeiro surpreendentemente conseguiu enviar um repórter de sua redação ao encontro de Perón, que falou abertamente em retomar o antigo projeto proposto pelo Barão do Rio Branco. Na reportagem, o jornalista brasileiro Flávio Damm pouco espaço deu às declarações do presidente. No lugar, apresentou uma interpretação particular das relações internacionais sul-americanas. Assegurou que a ideia do Pacto $A B C$, resgatada pelo governo argentino, era um novo petardo do "arsenal da demagogia continental" justicialista. Em suas palavras:

Na verdade, o $\mathrm{ABC}$ não passa de um jogo de Perón, de uma espécie de arapuca que ele arma com o fim de nela fazer cair o Brasil e o Chile. Necessitando de fortalecer a posição da Argentina, prega ele a formação de um bloco continental com a incorporação de dois dos mais importantes países da América Latina e apresenta-se, ele próprio, como o anjo tutelar dos interesses políticos e econômicos das nações que o ABC pretende congregar. O jogo é disfarçado, mas não a ponto de que não se possa ver claramente o que Perón quer [...]. O momento realmente é o mais propício para Perón se lançar à sua sorrateira aventura imperialista. Ele acredita piamente que os Estados Unidos, ludibriados com os passes de mágica que a Argentina vem fazendo na sua política externa, veja com bons olhos a formação do $\mathrm{ABC}$, condescendente em admitir os propostos democráticos dessa aliança imaginada em Buenos Aires. Perón apenas procura ganhar tempo. Uma vez eleito, e concretizado o pacto que ele tirou da cachola, o general estará pronto para voltar à sua posição intransigentemente antiamericana, arrastando na sua aventura totalitária o Brasil e o Chile. ${ }^{551}$

À essa altura era embaixador do Brasil em Buenos Aires João Batista Lusardo, apelidado de "Centauro dos pampas" por seus simpatizantes. Após longa hesitação de Vargas, ele foi recolocado no posto, em agosto de 1951, o que gerou muitas críticas dos jornais liberais-conservadores e dos udenistas. Dada sua explícita proximidade com o mandatário argentino, houve intensas discussões sobre sua indicação no Senado, mas seu nome acabou ratificado em votação. Dias depois, Lusardo foi novamente recebido com muita pompa no aeroporto e, numa quebra de protocolo, ganhou um apertado abraço do presidente argentino, que exclamou: "Mi querido Embajador!". 552

A partir de então, os ataques se intensificaram. No lápis de Hilde (figura 17), a indicação de Lusardo teria sido uma imposição ao presidente Vargas por parte de Perón que, com cara de poucos amigos, empunha um documento com a palavra ultimatum. Vale destacar que já havia no período elucubrações em torno de uma dívida eleitoral do presidente brasileiro para com o mandatário argentino. Ao lado deste, figura Lusardo

\footnotetext{
${ }^{551}$ DAMM, Flavio. "Perón não tem a bomba atômica" In: O Cruzeiro, Rio de Janeiro, 22/9/1951.

${ }^{552}$ CARNEIRO, op. cit., p. 373.
} 
com um sorriso maroto. Em uma interpretação possível, a representação do embaixador com ar malandro remete a denúncias da época em torno do enriquecimento ilícito do político gaúcho após sua primeira passagem pela embaixada brasileira. Seu retorno lhe garantiria a continuidade dos negócios escusos - daí o ar de satisfação.

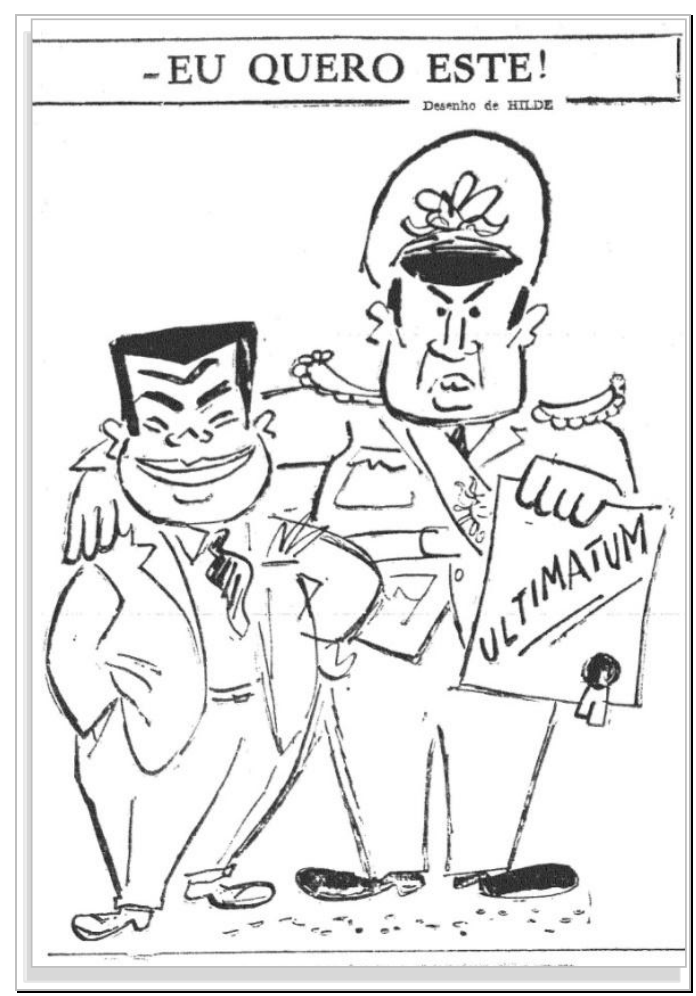

Figura 17 - HILDE. Tribuna da Imprensa, 18-19/08/1951, p. 4

Três meses depois da posse de Lusardo, em artigo publicado na Tribuna da Imprensa, o antiperonista Agustín Rodriguez Araya, exilado no Uruguai, insinuou que Lusardo estava sendo subornado pelo regime argentino, pois teria enriquecendo ilegalmente ao realizar contrabando na fronteira e "fazer negócios de toda espécie com o governo junto ao qual exerce suas funções". Em suas palavras: "No ritmo em que vão os negócios do embaixador Luzardo [...] ninguém se admiraria se na Embaixada do Brasil em Buenos Aires fosse colocada uma placa dizendo: 'Faz-se qualquer negócio'. 553

Nos anos seguintes, Lusardo continuou sendo retratado diuturnamente como um "cúmplice, um sócio da empreitada peronista". ${ }^{554}$ Em certa ocasião, Lacerda afirmou:

\footnotetext{
${ }^{553}$ ARAYA, Agustin Rodriguez. "Os negócios do embaixador Lusardo" In Tribuna da Imprensa, Rio de Janeiro, 17-18/11/1951, p. 4 e 5.

${ }_{554}$ LACERDA, Carlos. "O verdadeiro caráter do movimento peronista" In Tribuna da Imprensa, Rio de Janeiro, 23/10/1951, p. 4.
} 
"Brasil não tem um embaixador, tem um serviçal do peronismo". ${ }^{555}$ E completou: "[ele] fez à custa da traição uma das mais rápidas fortunas que se tem notícia na história dos personagens desse gênero". 556

Nesse ínterim, travou-se nos bastidores do Itamaraty uma luta surda entre o ministro das Relações Exteriores, o também gaúcho João Neves da Fontoura, e Lusardo. O primeiro era contra a formação de blocos regionais e a favor da manutenção dos ideais pan-americanos e do alinhamento em relação aos Estados Unidos, posição contrária à defendida pelo governo argentino e pelo embaixador brasileiro, favoráveis a entendimentos regionais. ${ }^{557}$ Em suas memórias, Lusardo assegurou que as divergências surgiram antes mesmo de sua posse, quando João Neves lhe pediu, em nome da longa amizade, que ele recusasse o convite de Vargas para a embaixada na capital portenha. Para Neves, isso acirraria ainda mais as críticas ao governo por parte da UDN, que há anos os hostilizava. ${ }^{558}$ Lusardo rejeitou o pedido do amigo e mudou-se para Buenos Aires. $^{559}$

Essas divergências em relação à política externa se refletiam na imprensa. Se os meios de comunicação liberais-conservadores voltavam suas ferinas baterias contra Lusardo, João Neves da Fontoura também foi fustigado com frequência pelos jornais platinos, que o retratavam continuamente como inimigo da Argentina e lacaio do imperialismo norte-americano. ${ }^{560}$ Do Brasil também vieram ataques que, segundo ele, eram oriundos do escasso, porém militante "justicialismo indígena", que "fazia causa comum com a extrema esquerda para perturbar a política externa por mim desenvolvida". 561

Esse antagonismo dentro do Itamaraty aflorou mais fortemente em um episódio ocorrido no início de 1953, que foi narrado nas memórias de Lusardo. ${ }^{562}$ Perón, por

555 LACERDA, Carlos. "União entre Perón e a Rússia" In Tribuna da Imprensa, Rio de Janeiro, 24/10/1951, p. 4.

${ }^{556}$ LACERDA, Carlos. "O verdadeiro caráter do movimento peronista" In Tribuna da Imprensa, Rio de Janeiro, 23/10/1951, p. 4.

${ }_{557}^{55}$ RECKZIEGEL, op. cit., p. 41-90.

${ }^{558}$ CARNEIRO, op. cit., p. 364-366.

${ }^{559}$ De acordo com a historiadora Raquel Paz dos Santos, a gestão de Lusardo na embaixada foi marcada, entre outros aspectos, pela ampliação significativa do intercâmbio de atividades culturais entra Brasil e Argentina. Ver: SANTOS, Raquel Paz dos. "O impacto do projeto do ABC nas relações Brasil-Argentina durante o segundo governo Vargas” In OPSIS, Catalão-GO, v. 14, n. especial, 2014, p. 47-48.

${ }^{560}$ RECKZIEGEL, op. cit., p. 87.

${ }^{561}$ FONTOURA, op. cit., p. 28.

${ }^{562}$ Curiosamente, muito do que se sabe sobre os bastidores desses momentos vem das memórias de Lusardo, que, por estranho que pareça, foram publicadas pela editora Nova Fronteira, de propriedade de Carlos Lacerda. Em 1977, em um depoimento meses antes de sua morte, o jornalista fluminense deixou claras suas intenções ao dar voz a Lusardo: "no livro - que é muito bom - ele [Lusardo] me ataca várias 
intermédio do embaixador brasileiro, teria informado a Vargas sua intenção de iniciar o Pacto $A B C$ com entendimentos econômicos com o Chile. A aproximação com o Brasil ocorreria posteriormente. Nas palavras de Lusardo, Vargas teria "mordido a isca", ou seja, concordado secretamente com os passos iniciais do projeto. Todavia, frisou a Lusardo que:

Perón teria, não a palavra oficial do Brasil, mas um consentimento preliminar, reservado; que ele conversasse com o Chile, adiantando mais ou menos que o Brasil ia aceitar. Tempos depois, dependendo do que resultasse da conversa com o Chile, se formalizaria o assunto. ${ }^{563}$

No entanto, dias antes de visitar o Chile para firmar os acordos econômicos (Ata de Santiago), Perón empolgou-se em uma entrevista e imprudentemente declarou que estava seguro de que em breve "virá a união com outros países, como o Brasil, por exemplo" ${ }^{564}$ Nas palavras de Lusardo, as afirmações do chefe da Casa Rosada caíram como "uma bomba na América Latina". ${ }^{565}$ Poucos dias depois, João Neves da Fontoura reagiu e, aparentemente sem o consentimento de Vargas, pronunciou um duro discurso em um almoço oficial do Itamaraty. Nele, garantiu:

\begin{abstract}
O Brasil não está interessado na formação de quaisquer blocos regionais nem no estabelecimento de facções continentais em detrimento do conjunto. [...] No Império como na República, o Brasil tem sido inflexivelmente fiel ao conceito do pan-americanismo como uma comunidade de Nações livres, orientadas no sentido de se aperfeiçoarem as formas democráticas internas por um laço comum de fidelidade à paz, à independência e à liberdade de todos os povos. ${ }^{566}$
\end{abstract}

De acordo com Lusardo, Perón teria ficado profundamente contrariado com a negativa brasileira e assim que voltou de Santiago o teria convocado para dar explicações. Este lhe garantiu que as opiniões do chanceler brasileiro não refletiam as do presidente. ${ }^{567}$ Dias depois, o mandatário da Casa Rosada recebeu também a visita do jornalista brasileiro Geraldo Rocha, amigo dos dois líderes sul-americanos, que lhe teria informado da difícil situação política de Vargas e da impossibilidade de controlar as

\footnotetext{
vezes, mas diz que houve realmente um entendimento entre o Perón e o Jango, e é isso que me interessa. Ele conta sem detalhes, mas confirma o negócio direitinho". ${ }^{562}$ Lacerda, no entanto, não viu a obra pronta, pois morreu em circunstâncias suspeitas meses antes do lançamento. Ver: LACERDA, 1978, op. cit, p. 108.

${ }^{563}$ CARNEIRO, op. cit., p. 434

564 Correio da Manhã, 19 de fevereiro de 1953. Disponível nas cartas de João Neves da Fontoura a Getúlio Vargas. CPDOC/RJ FGV - Documento GV c 1953.02.18/1.

565 Idem.

${ }^{566}$ FONTOURA, op. cit., p. 13-14.

${ }^{567}$ CARNEIRO, op. cit., p. 434-435.
} 
ações de João Neves da Fontoura. Em seguida, o próprio Perón enviou uma carta agradecendo as aclarações do intermediário e reafirmando sua amizade com o presidente brasileiro. A missiva reservada, de 6 de março de 1953, ficou preservada na documentação pessoal do político gaúcho. Eis os trechos mais significativos:

\begin{abstract}
Estimado presidente,
Recebi sua mensagem por intermédio do dom Gerardo [sic] Rocha; muito lhe agradeço por suas amáveis recordações.

O que me conta, esclarece para mim, uma situação confusa referente aos últimos acontecimentos, pois me era difícil relacionar seu juízo sobre minha viagem ao Chile, com as declarações do ministro das Relações Exteriores do Brasil e o ataque sistemático da imprensa de seu país. O que me conta dom Gerardo explica a questão e me dei conta da difícil situação em que V. Exa. está vivendo. [...]

Eu somente desejo reafirmar-lhe que estou leal e sinceramente na posição de sempre. Minha política é precisamente aquela da sinceridade mais absoluta, como tentei provar-lhe em todas as circunstâncias, cumprindo lealmente quanto nos prometíamos há três anos[...].
\end{abstract}

Receba uma afetuosa saudação do seu amigo, Juan Domingo Perón. ${ }^{568}$

Em junho, apenas três meses depois desses acontecimentos, a crise econômica, as greves e as difíceis relações com a UDN, que relutava em fazer uma conciliação com o governo, levaram Vargas a uma ampla reforma ministerial, que substituiu quase todas as pastas civis. João Neves da Fontoura foi trocado pelo simpatizante udenista Vicente Rao.

Coincidentemente, dias antes Fontoura havia entrado em outra polêmica com o governo argentino a respeito de um caso rumoroso de reexportação de café. Todavia, assegurou em um depoimento que sua saída não teve qualquer relação com uma reorientação da política externa varguista: "Meu pedido de exoneração foi devido à crise interna; e só a ela". 569

Enquanto parte dos jornais argentinos comemorou a alteração, a imprensa liberal-conservadora brasileira interpretou a mudança como uma imposição de Perón. Para Lacerda especificamente, João Neves da Fontoura havia sido sacrificado como oferenda de Vargas a Perón. ${ }^{570}$ Nas páginas de O Cruzeiro, Franklin de Oliveira investiu contra o governo com grande virulência:

\footnotetext{
${ }^{568}$ Correspondência pessoal de Getúlio Vargas. FGV CPDOC/RJ - Documento GV c 1953.03.06/2 (tradução nossa).

${ }^{569}$ FONTOURA, op. cit., p. 48.

${ }^{570}$ LACERDA, Carlos. “O traidor traído” In Tribuna da Imprensa, Rio de Janeiro, 10/3/1954, p. 4.
} 
Pois não é que, para satisfazer às impertinências e dar gáudio e folgança à basofia de um vizinho insólito e incômodo, [Vargas] não hesitou em fazer um churrasco gaúcho de um de seus terneiros mais diletos? Imolando o Sr. João Neves à sanha publicitária de um caudilho que jugula com o peso da sua tirania uma nação fraterna, que manipula através do terror, do cárcere e da corrupção a degradação de um nobre povo, ao qual devíamos assistir no seu sofrimento e jamais compatibilizamos com o seu verdugo, imolando um Chanceler Brasileiro às necessidades de demagogia interna de um tiranete, tanto mais abjeto quanto caricato, a Revolução de 30 mostrou que retornou ao poder não com os cabelos brancos de sabedoria, mas da mais opaca obtusidade. [...] Volte a doce avozinha ao seu natural e, se quiser mesmo brindar a voracidade do cômico déspota portenho com um churrasco regional, que o faça queimando as obsequiosas enxúndias do Sr. Batista Luzardo, que está mais próximo do espeto e das garras do devorador. As banhas, a gordura mercantil do embaixador de Perón junto a Perón, derretidas ao fogo da insânia justicialista, azeitarão melhor a máquina que ali se montou para triturar a liberdade e a vida digna do povo argentino. O que o Brasil não pode aceitar é que, à edacidade de um régulo de tanto, se imole um dos nossos mais altos valores, como esse João Neves que, na Casa de Rio Branco portou-se à altura das tradições do grande defensor da dignidade internacional do Brasil. $^{571}$

Hilde Weber destacou que a escolha do substituto passaria pela opinião de Perón. Na figura 18, Vargas, colocado na condição de vendedor de uma loja de brinquedos ("Casa da Reforma"), oferece ao presidente argentino um novo político que poderia ocupar o cargo. Não foi possível identificar quem é. Abandonado sobre a mesa está o boneco de João Neves da Fontoura. Embora segure um charuto, marca de despreocupação, o semblante de Getúlio transmite angústia, sinalizando possivelmente seu enfraquecimento político. Sua própria posição na cena, dando a Perón a chance de escolha, o coloca em posição de inferioridade em relação ao líder platino.

571 OLIVEIRA, Franklin de. "A volta da vovó". Coluna Sete Dias In O Cruzeiro, Rio de Janeiro, $11 / 7 / 1953$. 


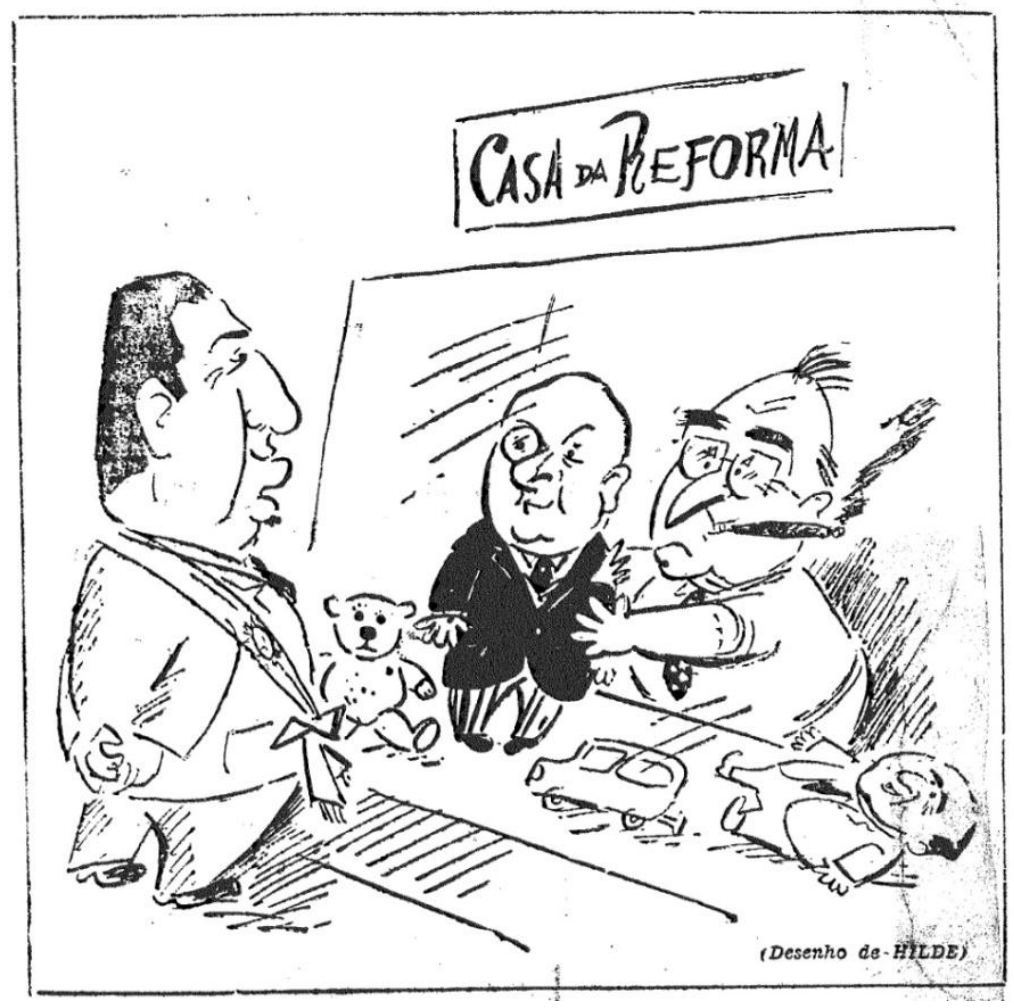

Figura 18 - HILDE. Tribuna da Imprensa, 22/6/1953, p. 4.

Como se pode perceber, a saída de João Neves da Fontoura ampliou muito as críticas sobre Vargas, pois a mudança foi entendida como uma reorientação de sua política externa no sentido de uma aproximação com Buenos Aires. Conhecedor das dificuldades políticas do momento, Lusardo colocou seu cargo à disposição numa carta a Vargas em julho daquele ano: "Nunca lhe criei dificuldades e não seria agora que começaria a fazê-lo [...] se os interesses da política forem esses, não tenha o menor constrangimento em mandar para Buenos Aires outra pessoa". Ao final da missiva, defendeu que o governo estivesse atento "às coisas verdadeiramente sérias, em vez de tanto nos preocuparmos com campanhas inúteis de imprensa". 572

No mês seguinte, o embaixador anunciou sua saída para evitar desgaste ainda maior do governo. ${ }^{573}$ Exonerado em outubro, foi substituído por Orlando Leite Ribeiro, um experiente diplomata de tendência varguista. ${ }^{574}$ A troca aplacou apenas temporariamente a fúria da oposição. Meses depois, Lacerda voltou suas baterias contra o novo representante diplomático, a quem definiu como um "notório provocador e

\footnotetext{
${ }^{572}$ Carta de Batista Luzardo a Getúlio Vargas de 06/07/1953 (CPDOC - FGV-RJ GV c 1953.07.06/1) ${ }^{573}$ CARNEIRO, op. cit., p. 455. ${ }^{574}$ CAVLAK, op. cit., p. 65-66.
} 
intrigante internacional" $" 575$, "comunistóide" $" 576$ e "responsável pela infiltração comunista em postos diplomáticos". 577

As especulações em torno de conversas secretas com o líder platino também continuaram fervilhando. Em setembro, Vargas retirou-se da capital federal por dez dias para descansar em São Borja, na fronteira com a Argentina, após dezenove meses de trabalho ininterrupto. Uma visita à fazenda de Lusardo nesses dias deu margem à ampliação dos boatos em torno de uma "república sindicalista" e de conversas secretas com Perón. ${ }^{578}$ Naquele momento, $O$ Cruzeiro notou que "a inexistência do encontro deve ter decepcionado os que anseiam por acontecimentos perturbadores da vida nacional". 579

O cenário político era complicado para os petebistas. Denúncias de corrupção envolvendo o governo se acumulavam na imprensa de oposição, que, a partir de Lacerda, definiu a situação como "um mar de lama”. O quadro de inflação, greves e contínuos escândalos piorou ainda mais no início do ano seguinte. A atuação do ministro João Goulart, em especial, provocou forte reação nos quartéis. Esta culminou na veiculação do "Manifesto dos Coronéis", assinado por 82 oficiais da ala conservadora do Exército no Rio de Janeiro. O documento com críticas às condições da caserna e à política de aumento do salário mínimo de Jango abriu uma grave crise política. Em um claro sinal de enfraquecimento do presidente, o jovem ministro foi demitido, a contragosto de Vargas, no final de fevereiro de 1954.

$\mathrm{O}$ texto do manifesto não trouxe qualquer menção à Argentina peronista. No entanto, o senador udenista Hamilton Nogueira criticou naqueles dias a "peronização do Brasil" e asseverou que Jango estava "jogando os empregados contra os empregadores". ${ }^{580}$ Outro udenista, o potiguar José Ferreira de Sousa, também atacou: “Todos sabemos dos esforços imensos que se vêm desenvolvendo no setor do Ministério do Trabalho no sentido de, falhando à finalidade superior do sindicato [...], desviar a ação dessas entidades para o mundo político, tentando numa espécie de

\footnotetext{
575 “Interpelação urgente” In Tribuna da Imprensa, Rio de Janeiro, 13-14/3/1954, p. 4.

576 LACERDA, Carlos. "Perón cumple, pero Vargas no dignifica" In Tribuna da Imprensa. Rio de Janeiro, 15 de março de 1954, $1^{\text {a }}$ seção, p. 4.

577 Idem

${ }^{578}$ NETO, op. cit., p. 256-260.

${ }^{579}$ QUEIROZ, Olavo de e RONEK, Antônio. "Visita presidencial ao Sul” In O Cruzeiro, Rio de Janeiro, 31/10/1953.

580 "Ferreira de Souza no Senado: "Se há desordem, unamo-nos todos para combatê-la" In Tribuna da Imprensa, Rio de Janeiro, 17/2/1954, p. 3.
} 
lamentável mimetismo copiar ou seguir as lições de um ditador da América do Sul". 581 Nos traços de Hilde Weber, a saída de João Goulart foi comemorada com uma referência mordaz ao justicialismo. Demitido, o político gaúcho voltaria à vida boêmia e a Argentina peronista, onde poderia bailar o tango (figura 19).

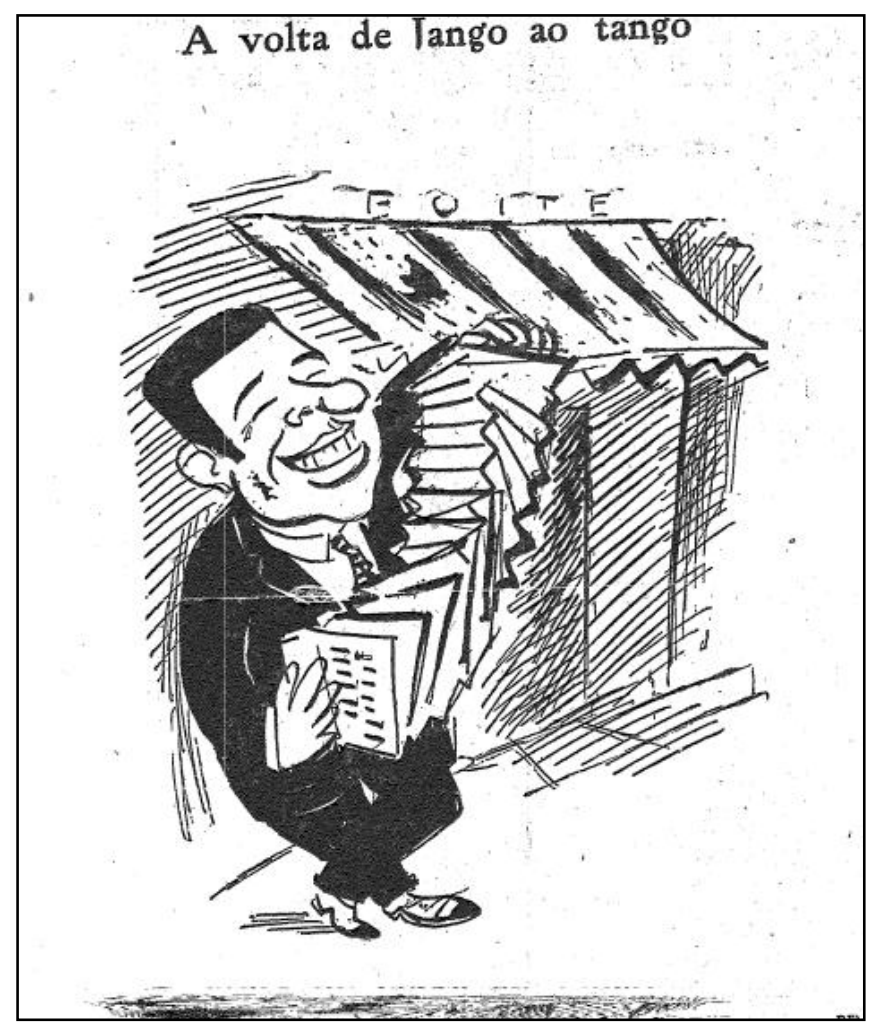

Figura 19. Tribuna da Imprensa. 23/2/1954, 1을 caderno, p. 4.

Apenas duas semanas depois da demissão de Goulart, o governo teve de enfrentar mais um imbróglio. Em 9 de março de 1954, a Tribuna da Imprensa publicou em primeira mão um discurso informal e secreto que Perón fizera aos militares na Escola Superior de Guerra em Buenos Aires em 11 de novembro do ano anterior. De acordo com o jornal, o pronunciamento fora divulgado inicialmente pelos Cuadernos de la Resistencia Argentina, brochura publicada no Uruguai por exilados argentinos, e repassado por Agustín Rodriguez Araya, ex-deputado radical, que, a partir de Montevidéu, colaborava constantemente com artigos antiperonistas. ${ }^{582}$

É importante analisar em detalhes o conteúdo desse controvertido e longo discurso. A partir de sua perspectiva, Perón indiscretamente narrou em minúcias aos oficiais presentes diversos episódios diplomáticos envolvendo a construção do Pacto

\footnotetext{
${ }^{581}$ Idem.

582 "Perón revela acordo com Vargas" In Tribuna da Imprensa, Rio de Janeiro, 9/3/1954, p. $1\left(1^{\circ}\right.$. caderno) e p. 5 ( $2^{\circ}$. caderno).
} 
$A B C$. Se confirmados, os fatos narrados comprometeriam significativamente o presidente brasileiro.

Há, na parte inicial do pronunciamento, uma digressão sobre o futuro das relações internacionais. Segundo Perón, a construção de um mundo superpovoado e superindustrializado inevitavelmente levaria as grandes potências a buscar o domínio de regiões com grandes reservas de alimentos e matérias-primas, caso da América do Sul. A existência de países pequenos e fracos no subcontinente facilitaria esse processo. Por isso, seria necessário "encarar de frente a possibilidade de uma união real e efetiva de nossos países, para encarar uma vida em comum e para planejar também uma defesa em comum". Perón lamentou que outras iniciativas de união política latino-americana, como as que ocorreram no período de independência, tivessem fracassado. E emendou: "Penso que o ano 2000 nos vai surpreender ou unidos ou dominados". 583

Ele explicou, ainda, que, dada a transitoriedade dos governos e o anacronismo das chancelarias, a melhor estratégia para atingir a união latino-americana seria "influenciando os povos". Esse seria "talvez o único êxito extraordinário do comunismo", que não trabalharia com os governos, "senão com os povos porque eles [comunistas] estão encaminhados a uma obra permanente e não a uma obra circunstancial". Partindo dessa ideia, o governo argentino teria, a partir de 1946, começado a "trabalhar sobre os povos, sem excitação, sem pressa e, sobretudo, tratando de cuidar minuciosamente de desvirtuar toda possibilidade de que nos acusem de intervenção nos assuntos internos de outros Estados". 584

Perón destacou também que a união deveria ser feita "devagarzinho, sem pressões e violências de outra natureza" e, em outro trecho completou: "Não se pode duvidar que, realizada essa união, cairão em sua órbita os demais países sul-americanos $[\ldots]^{\prime}$.

Para dar início à integração regional, o mandatário argentino defendeu a criação de uma unidade econômica entre Argentina, Brasil e Chile, tida por ele como "a mais extraordinária do mundo inteiro", dada a imensa disponibilidade de reservas naturais dos três países. Nas suas palavras, "os grande impérios, as grandes nações, têm chegado, desde o começo da história até nossos dias, às grandes conquistas com base na unidade econômica". Tendo isso em mente, afirmou Perón: "Eu comecei a trabalhar sobre os povos [...] preparando a opinião para receber bem essa ação".

\footnotetext{
${ }^{583}$ PERÓN, Juan Domingo. La hora de los pueblos. Buenos Aires: Norte, 1968 (tradução nossa).

${ }^{584}$ Idem.
} 
De acordo com a narrativa do líder justicialista, ele teria conversado com Vargas e Ibañez antes das eleições no Brasil e Chile. O governante brasileiro, em especial, teria se mostrado "total e absolutamente de acordo com essa ideia [de integração] e em realizá-la tão logo ele estivesse no governo". Perón aduziu:

Quando Vargas subiu ao governo me prometeu que nos reuniríamos em Buenos Aires ou no Rio e faríamos esse tratado que eu firmei com Ibañez depois; o mesmo tratado.

Esse foi um propósito formal que havíamos traçado. Mais ainda, dissemos: "Vamos suprimir as fronteiras, se for preciso". [...]

Mais tarde Vargas me disse que era difícil que pudéssemos fazê-lo tão cedo, porque ele tinha uma situação política um pouco complicada no Congresso e que antes de dominá-lo queria fazer uma conciliação. É difícil isso em política - é necessário primeiro dominar e depois a conciliação vem sozinha. São pontos de vista; são maneiras distintas de pensar. ${ }^{585}$

No caso brasileiro, Perón apontou uma dificuldade adicional: a atuação do Itamaraty, tido como uma instituição supragovernamental, que criava grandes entraves à integração. Ele atacou: "Deve desmontar-se todo o sistema do Itamaraty e devem desaparecer essas excrescências imperiais que constituem, mais do que nenhuma outra razão, os principais obstáculos para que o Brasil entre em uma, digamos, união verdadeira com a Argentina". 586

Ciente das dificuldades internas enfrentadas por Vargas, Perón teria resolvido iniciar o processo de aproximação econômica com um acordo inicial com o Chile, governado pelo general Ibañez. De acordo com ele, "o general foi mais decidido porque costumamos ser mais decididos do que os políticos”. Antes de viajar a Santiago, porém, teria solicitado a Lusardo autorização para iniciar os entendimentos sem a participação inicial do Brasil. Em sua versão dos acontecimentos, a resposta teria sido bastante animadora:

[Vargas] não somente me autorizava que fosse ao Chile, liberando-me do compromisso, senão que me dá também sua representação para que eu o faça em nome dele no Chile. Naturalmente já sei agora muitas coisas que antes não sabia; aceitei somente a autorização, mas não a representação. ${ }^{587}$

No entanto, a aprovação da Ata de Santiago, em fevereiro de 1953, provocou fortes declarações na imprensa do ministro das Relações Exteriores do Brasil, João

\footnotetext{
585 Idem.

586 Idem.

${ }^{587}$ Idem.
} 
Neves da Fontoura. Perón teria ficado inicialmente sem entender o que se passara com o governo do Rio de Janeiro. A explicação viria dias depois:

\begin{abstract}
Quando cheguei me encontrei com Geraldo Rocha, velho jornalista de grande talento, diretor de "O Mundo" no Rio, muito amigo do presidente Vargas, que me disse: "Me manda o presidente Vargas para que lhe explique o que aconteceu no Brasil. Disse que a situação dele é muito difícil; que politicamente não pode dominar; que tem secas no Norte, geadas no Sul, e que os políticos estão contra ele, que o comunismo está muito perigoso, que não pôde fazer nada; enfim, que o desculpe, que ele não pensa assim e que o ministro fez isso, que ele tampouco pode mandar no ministro". 588
\end{abstract}

Após narrar esses percalços na construção do Pacto $A B C$, o líder justicialista mostrou-se bastante confiante. Nos últimos momentos do pronunciamento, declarou aos aos militares argentinos presentes: "Essa união, senhores, está em plena elaboração: é, tudo quanto eu posso dizer-lhes em definitivo". 589

A publicação desse discurso secreto de Perón pela Tribuna da Imprensa, em marco de 1954, caiu como uma bomba no já tumultuado cenário político brasileiro. O pronunciamento foi um prato cheio para a oposição, que vinha insistindo há anos na existência de relações secretas entre os dois líderes. "Traição" foi o termo mais utilizado para classificar a atuação de Vargas no caso. Lacerda defendeu que a interpelação do presidente era "uma grande oportunidade de levantar a UDN à altura de suas responsabilidades, já não somente na defesa do regime, mas no próprio decoro nacional". ${ }^{590}$ Discursos de líderes udenistas cobrando explicações também receberam ampla cobertura no diário. ${ }^{591}$

Hilde Weber destacou as conversas secretas. Na charge, o pequenino Getúlio (cerca de 1,60 de altura), que agiria na escuridão, pede silêncio a Perón após serem descobertos em seus planos (figura 20). A lanterna da cena pode remeter a pelo menos dois aspectos. Em primeiro lugar, era o símbolo do próprio jornal e relacionada ao ideal de objetividade da imprensa que reivindicava o posto de reveladora da verdade, ou seja, promotora das luzes. Nesse sentido, também é curiosa a descoberta do "crime" por várias pessoas e não apenas uma. Isso alude à tradicional noção do jornalismo como voz da opinião pública, ou seja, meio de expressão de toda sociedade e não de interesses particulares. Em segundo lugar, vale lembrar que Lacerda e outros udenistas haviam

\footnotetext{
${ }^{588}$ Idem.

${ }^{589}$ Idem.

590 “Interpelação urgente” In Tribuna da Imprensa, Rio de Janeiro, 13-14/3/1954, p. 4.

591 "Pacto ABC: violação das tradições brasileiras" In Tribuna da Imprensa. Rio de Janeiro, 15 de março de 1954 , p. 3.
} 
fundado em 1953 um grupo de militares e civis de postura radicalmente antigetulista e anticomunista que carregava o sugestivo nome de "Clube da Lanterna". 592

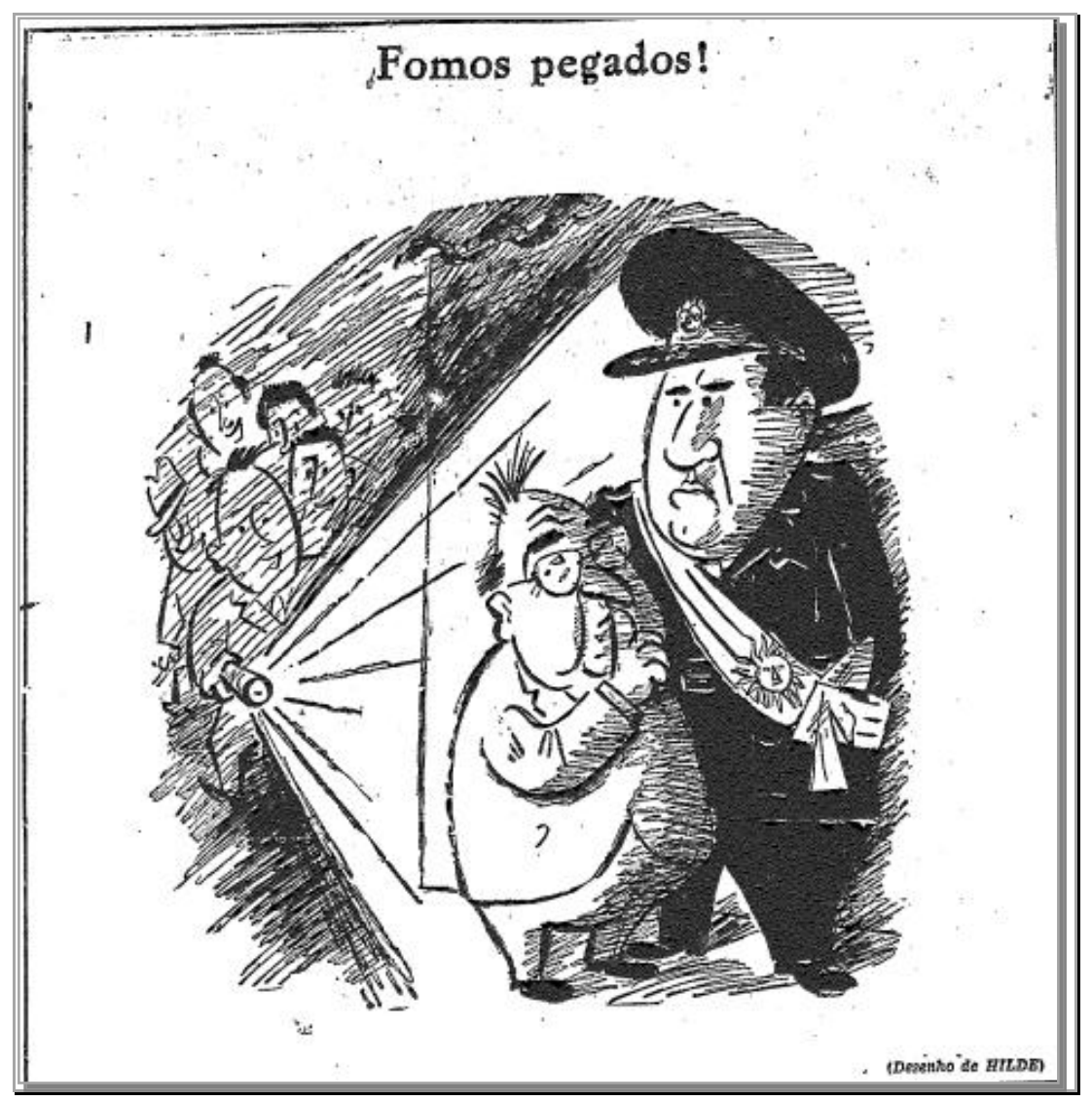

Figura 20 - HILDE. Tribuna da Imprensa, 17/3/1954, p. 4.

O Cruzeiro acompanhou a distância a polêmica envolvendo o discurso de Perón, malgrado os ataques ao governo feitos pelos meios de comunicação de Assis Chateaubriand tivessem se ampliado após a criação da Petrobrás, em 1953. Lacerda, por sua vez, não perdeu a oportunidade de atacar o presidente. Nos meses seguintes, em uma série de editoriais, insistentemente chamou Vargas de traidor, alegando que ele tentara romper a unidade continental e a "tradição diplomática" de alinhamento aos Estados Unidos traçada pelo Itamarati. Termos como conjura e conspiração também foram repetidos à exaustão. Assim que o discurso foi divulgado, ele assinou o texto " $\mathrm{O}$ traidor traído" no qual afirmou:

O crepúsculo do sr. Getúlio Vargas é o mais melancólico. Por merecido que seja, causa piedade. $\mathrm{O}$ sr. Vargas, à força de ser esperto, acaba por se tolo.

${ }^{592}$ BENEVIDES, op. cit., p. 86. 
Enganou o Brasil com o chefe argentino - e acabou desmascarado por este. Enganou os Estados Unidos com a Argentina - e acaba de joelhos implorando dinheiro aos americanos, sujeitando-se a todas as condições. ${ }^{593}$

Embora Perón não tenha citado João Goulart em nenhum trecho do discurso, Lacerda não hesitou em apontá-lo, junto com Lusardo, como "agentes da traição internacional". ${ }^{594}$ A lentidão da Embaixada argentina em negar a autenticidade do discurso favoreceu a ampliação das suspeitas. Nesse momento, Lacerda escreveu:

[...] desarvorados, os elementos palacianos não sabem o que fazer para conseguir um desmentido do Governo argentino, que coloque o sr. Vargas em melhor situação. [...]

$\mathrm{O}$ chefe argentino, traído, não poupou o traidor que se havia mancomunado com ele.

Daí a perplexidade no Governo, que há vários dias está tonto, sem saber o que faça e o que diga. Daí a evasiva do rombudo Luzardo, que encontra na sua notória boçalidade limites naturais para a sua insensibilidade ao interesse nacional. ${ }^{595}$

O desmentido veio apenas quatro dias depois, em 13 de março. Afirmava que a publicação do discurso era "totalmente falsa e destituída de verossimilhança". Foi assinado não pelo embaixador, Juan Isaac Cooke, mas pelo encarregado de negócios no Rio de Janeiro, Fernando Torquato Isninsausti, que aduziu:

O Exmo. Senhor Presidente da República Argentina não só não pronunciou tal discurso como não podia, em caso algum, exprimir conceitos que se encontram em completa oposição ao seu espírito de governante que não deseja senão realizar uma política permanente, de estreita solidariedade com todos os governos e povos do Continente Americanos. Por isso torna-se inconcebível que lhe sejam atribuídas manifestações que não estão de acordo com seu profundo respeito pela soberania e pela igualdade jurídica dos Estados. ${ }^{596}$

Não houve qualquer outra declaração oficial a partir de Buenos Aires, o que não passou despercebido pelos antiperonistas. ${ }^{597}$ Tendo em vista o enorme terremoto político que o pronunciamento provocara, Lacerda considerou a explicação insuficiente:

Com esse pífio desmentido contentar-se-ão os ingênuos, se ainda existem, e os que não querem outra coisa senão pôr uma pedra em cima do assunto para ir adiante na mesma cínica sequência pela qual o sr. Vargas, não contente de emporcalhar o Brasil aqui dentro com a proteção que dispensa aos negocistas,

\footnotetext{
${ }^{593}$ LACERDA, Carlos. “O traidor traído” In Tribuna da Imprensa, Rio de Janeiro, 10/3/1954, p. 4.

${ }^{594}$ Idem.

595 “Interpelação urgente” In Tribuna da Imprensa, Rio de Janeiro, 13-14/3/1954, p. 4.

${ }^{596}$ CPDOC/RJ - Documento GV c 1954.02.20/4.

597 “As cartas Perón-Vargas” In Tribuna da Imprensa, Rio de Janeiro, 22/3/1954, p. 3.
} 
ainda vai enxovalhá-lo no estrangeiro, com as tramas que urde com os ditadores. $^{598}$

Após a nota argentina, o governo brasileiro convenientemente deu o assunto por encerrado. Vargas afirmou que não se pronunciaria sobre ele, para evitar um "atrito internacional". 599 No entanto, em editorial intitulado "Perón cumple, pero Vargas no dignifica", nítida referência ao slogan peronista "Perón cumple, Evita dignifica", Lacerda buscou manter a discussão acesa:

Falta agora um desmentido cabal, frontal, completo do sr. Getúlio Vargas. Sim ou não, entendeu-se com Perón? Sim ou não, recebeu dele uma carta sobre a visita que ia fazer ao Chile? Quantas vezes esteve com Perón e o que foi que discutiram nesses encontros?

A Nação tem o direito de saber. Não há, entre o Brasil e a Argentina, nada de secreto - e se há está errado, portanto, deve tornar-se público.

O povo tem o dever de exigir do sr. Getúlio Vargas toda a verdade sobre os seus entendimentos secretos com o general Perón. Ao menos para não ficar sabendo dos compromissos do seu governo pela indiscrição, evidentemente intencional, dos seus parceiros traídos. ${ }^{600}$

Lacerda rebateu especialmente o argumento de que as ideias expressas no discurso eram inverossímeis. No editorial "Mais do que verossímil, exatíssimo", ele resgatou outro artigo de Perón publicado em 1951, sob o pseudônimo de "Descartes", intitulado "Confederaciones continentales". Em seu texto, o jornalista fluminense selecionou trechos dos dois documentos e demonstrou a grande semelhança entre eles. Embora hoje se saiba que "Descartes" era mesmo Perón, não havia tanta certeza no período o que, do ponto de vista dos leitores, pode ter enfraquecido a tese de Lacerda. Tampouco se sabia que, apesar do desmentido da Embaixada argentina, aquele discurso secreto que provocou tanta celeuma no Brasil realmente fora pronunciado pelo presidente argentino. ${ }^{601}$

\footnotetext{
${ }^{598}$ LACERDA, Carlos. "Perón cumple, pero Vargas no dignifica" In Tribuna da Imprensa, Rio de Janeiro, 15 de março de 1954, p.1

599 "Vargas nada diz sobre Perón" In Tribuna da Imprensa, Rio de Janeiro, 16/3/1954, p.1 e 2.

${ }^{600}$ LACERDA, Carlos. "Perón cumple, pero Vargas no dignifica" In Tribuna da Imprensa. Rio de Janeiro, 15 de março de 1954, p. 4, 1ª seção.

${ }^{601}$ Em 1968, quando se encontrava no exílio na Espanha, Perón finalmente permitiu que o discurso feito na Escola Superior de Guerra em 1953 fosse adicionado a um livro que compilava seus discursos. Alegou que se tratava de um documento histórico importante e que não mudaria o cenário naquele momento, pois Vargas e Ibañez já haviam falecido. Confirmou-se então pelo próprio autor que o polêmico pronunciamento era real. Ver: PERÓN, Juan Domingo. La hora de los pueblos. Buenos Aires: Norte, 1968. Na versão ampliada do pronunciamento, publicada quinze anos depois, aparece um último trecho, que não foi divulgado no Brasil à época. Nele, o líder justicialista encerra o discurso com certo tom triunfante: "A união continental à base da Argentina, Brasil e Chile está muito mais próxima do que creem muitos argentinos, muitos chilenos e muitos brasileiros; no Brasil, há um enorme setor que trabalha para isso. O único que é preciso vencer são interesses; mas, quando os interesses dos países começam a
} 
Se o jornalista fluminense farejou corretamente a autoria do texto, não se pode deixar de notar que a Tribuna da Imprensa, no afã de comprovar a autenticidade do pronunciamento secreto, abusou das ilações precipitadas. Uma notícia, por exemplo, resgatou o relatório do udenista Arnon de Mello e apressou-se em assegurar que aquele documento de 1949 era uma prova da veracidade das palavras proferidas recentemente por Perón. ${ }^{602}$ Lacerda também garantiu que o discurso confidencial mencionara “encontros sigilosos entre o sr. Vargas e o sr. Perón”, embora não houvesse a rigor qualquer referência explícita a uma reunião de corpo presente entre os dois mandatários. ${ }^{603}$

Além dessas inferências apressadas, veicularam-se também boatos, como o de que Lusardo confessara a "amigos íntimos" a realidade dos fatos narrados por Perón. ${ }^{604}$ Até mesmo jogos capciosos de palavras foram utilizados, como na manchete "[Afirma] Lourival: Vargas entendeu-se com Perón”. Ao contrário do que dá a entender esse título, o texto da notícia informava que o chefe da Casa Civil do governo, Lourival Fontes, defendeu o governo. Ele garantiu que os entendimentos entre os dois presidentes não excederam assuntos protocolares e que não haviam sido cogitados acordos secretos. ${ }^{605}$

Embora não tenha vindo a público para comentar o discurso, Perón encontrou-se naqueles dias finais de março com o novo embaixador do Brasil em Buenos Aires, Orlando Leite Ribeiro. Em carta secreta e pessoal, o diplomata datilografou a Vargas:

\footnotetext{
Pela conversa demorada de hoje, posso afirmar ao Presidente que o discurso em questão foi feito pelo General e talvez por ele próprio mandado difundir. Aproveitou da ingenuidade dos exilados argentinos e da nossa desgraçada oposição que fez exatamente o que ele desejava: a maior divulgação do seu discurso, sem a responsabilidade da Secretaria de Informações (Casa Rosada). ${ }^{606}$
}

\footnotetext{
atuar, os interesses dos homens devem ser vencidos por aqueles: essa é nossa maior esperança. Até que isso se produza, senhores, não temos outro remédio senão esperar e trabalhar para que se realize: e esta é nossa ação e esta é nossa orientação. Muito obrigado" (tradução nossa).

602 "Vargas nada diz sobre Perón” In Tribuna da Imprensa, Rio de Janeiro, 16/3/1954, p. 1 e 2.

603 "Interpelação urgente" In Tribuna da Imprensa, Rio de Janeiro, 13-14/3/1954, p. 4.

604 “Luzardo confirma Perón” In Tribuna da Imprensa, Rio de Janeiro, 11/3/1954, p. 1.

605 "Lourival: Vargas entendeu-se com Perón” In Tribuna da Imprensa, Rio de Janeiro, 20-21 de março de 1954, p. 1.

${ }^{606}$ Correspondência pessoal de Orlando Leite Ribeiro a Getúlio Vargas datada de 30/03/1954 (CPDOC/RJ GV c 1954.02.20/4).
} 
Curiosamente, Leite Ribeiro aduziu nesse documento um pequeno comentário com sua própria letra, que ficou preservado no acervo de correspondências do expresidente:

\begin{abstract}
Presidente, dada a confiança que nos merece o portador desta, eu poderei referir-me aqui a outro assunto mais sério ainda que ouvi do General [Perón] e sobre o qual dois de seus auxiliares mais imediatos já haviam falado $(O$ Tessaire e Nicolini [?]). É que o General já não faz segredo sobre a propalada ajuda material e combinações políticas que teriam sido feitas com emissários seus, antes e depois das eleições. Ao General e aos Ministros, respondi-lhes secamente, dizendo ter a certeza de que - se tais fatos ocorreram - o Sr. fora enganado por seus emissários, pois eu jamais ouvira falar sobre tais coisas, muito embora fosse igualmente pessoa de sua imediata confiança. ${ }^{607}$
\end{abstract}

Como se pode notar, a missiva apresenta indícios de que o presidente argentino ajudou emissários brasileiros que, autorizados ou não, advogaram interesses de Vargas no início da década de 1950. Do ponto de vista da documentação disponível não é possível afirmar mais do que isso. Se houve acertos secretos mais profundos entre Vargas e Perón naqueles anos, como queria a oposição antigetulista, eles não foram comprovados publicamente até o momento por esta ou outras pesquisas historiográficas.

O que se pode assegurar é que as relações com o justicialismo configuraram um rico filão para a oposição brasileira, pois a ideia de uma conspiração produzida junto com o governo argentino ganhou força rapidamente no discurso udenista. Ao que tudo indica, as frequentes representações a respeito dessa suposta aliança secreta entre varguistas e peronistas podem ser enquadradas naquilo que o historiador francês Raoul Girardet chamou de "mito da conspiração". 608

Bastante comum em várias sociedades, esse tipo de imaginário é construído para atribuir a inimigos supostos complôs e conluios imorais feitos com o intuito de controlar o poder. Agindo nas sombras, seus organizadores, por meio da influência externa, ameaçariam a ordem estabelecida ao tentarem tomar o poder e retirar a vontade própria dos cidadãos. Essa ameaça estrangeira justificaria a intervenção do lado supostamente correto para preservar a segurança e o bem de todos. Esse parece ter sido justamente o caso de líderes antiperonistas brasileiros, como Carlos Lacerda, que justificavam seu apelo a soluções extralegais argumentando que seus opositores agiam continuamente na ilegalidade.

\footnotetext{
${ }^{607}$ Idem.

608 GIRARDET, Raoul. Mitos e Mitologias Políticas. Tradução de Maria Lúcia Machado. São Paulo: Companhia das Letras, 1987.p. 25-62.
} 
Em suma, não se pôde até o momento provar que o perigo de um golpe ao estilo peronista com ajuda de Buenos Aires era real. Ao que tudo indica, o mais importante para jornais como Tribuna da Imprensa era apresentar uma história conspiratória minimamente coerente aos leitores para fazer com que eles acreditassem nessa possibilidade. Nessa perspectiva, aspectos concretos, como o discurso de Perón, foram propositalmente mesclados a suposições e especulações de modo a compor uma narrativa minimamente coerente e convincente.

Esses episódios mostraram também que, apesar de algumas semelhanças no campo político, os dois líderes tinham personalidades notadamente diferentes, o que, em alguma medida, influenciou a condução da política externa dos seus respectivos países. Como se pode perceber no caso da conferência secreta, Perón era mais expansivo e confessadamente pouco discreto em relação aos assuntos de Estado. ${ }^{609}$ Vargas, ao contrário, criou em torno de si o mito de um homem misterioso, de poucas palavras e com pensamentos inacessíveis. Enigmático para alguns, dissimulado para outros, ele foi criticado em diversas ocasiões por ser excessivamente hesitante.

Tendo isso em mente, não parece gratuito que historiadores brasileiros ainda hoje debatam sobre as reais intenções de Getúlio Vargas em levar a cabo acordos mais profundos com a Argentina peronista. Mônica Hirst notou que a política externa varguista tinha por objetivo primordial conseguir vantagens econômicas em relação aos Estados Unidos, tal qual havia ocorrido na Segunda Guerra. O contínuo fracasso dessa estratégia teria feito com que Vargas considerasse cada vez mais a possibilidade da formação de um bloco econômico sul-americano. Em uma análise conjuntural, a autora defende que o líder gaúcho fez um jogo ambíguo, pois "no avivaba la llama [da integração com a Argentina] pero tampoco dejara que se apagara totalmente", ${ }^{610}$

Muito mais crítica em relação à política externa varguista é a historiadora Ana Luiza Gobbi Setti Reckziegel. ${ }^{611}$ Segundo a autora, as relações entre os dois países sempre estiveram pautadas pela rivalidade, provocada especialmente pela pretensão constante de hegemonia na América do Sul. ${ }^{612} \mathrm{O}$ Pacto $A B C$, mesmo com uma fachada integracionista, seria uma continuidade das antigas disputas. ${ }^{613}$ Do ponto de vista de Reckziegel, Vargas teria iludido Perón ao flertar com um estreitamento de laços com a

\footnotetext{
${ }^{609}$ LUNA, 1985, op. cit., p. 295.

${ }^{610}$ HIRST, op. cit., p. 18.

${ }^{611}$ RECKZIEGEL, op. cit.

612 Ibidem, p. 30.

${ }^{613}$ Ibidem, p 167.
} 
Argentina. Tal encenação seria uma estratégia para agilizar a liberação de financiamento norte-americano, o que consolidaria a condição geopolítica do Brasil como parceiro privilegiado dos Estados Unidos. ${ }^{614}$ Explica a autora: "Vargas não intencionava levar a cabo a adesão ao ABC [...], mas sim utilizar essa possibilidade como elemento de barganha, já que não pretendia romper com a nação dominante". ${ }^{615} \mathrm{~A}$ artimanha, porém, não teria funcionado, especialmente porque o presidente enfrentou uma situação política interna difícil, na qual a imprensa e os grupos conservadores repudiavam qualquer aproximação com o peronismo.

Embora se reconheçam as importantes contribuições da obra de Reckziegel, tende-se aqui a não endossar sua interpretação central. A dura e longa campanha de acusações de traição à nação por supostamente fazer acordos secretos com Perón parece um preço alto demais a ser pago por Vargas em nome de uma possível barganha com os Estados Unidos. Uma fonte destacada pela própria autora aponta nesse sentido. Em carta datada de outubro de 1950, bem distante, portanto, da tentativa de impeachment sofrida em 1954, João Neves da Fontoura já advertia o então candidato gaúcho sobre o problema:

Desejo ainda pedir a tua atenção para as constantes explorações que a imprensa está fazendo a propósito da visita do Vice-Presidente da Argentina e das supostas ligações entre ti e o Perón. Essa é a tecla em que mais se martela em seu desfavor. ${ }^{616}$

A respeito do fracasso daquela tentativa de integração, concorda-se aqui com a perspectiva de Iuri Cavlak $^{617}$ e, em especial, da historiadora Daniella Xavier V. G. Santos. Em sua dissertação de mestrado, ela defendeu a inexistência de condições políticas para tal projeto naquele momento. Afinal, estiveram contra o Pacto $A B C$ forças poderosíssimas, como a oposição, representada pela UDN e a imprensa ligada a ela, setores das Forças Armadas brasileiras, os Estados Unidos, alguns países vizinhos e o próprio Itamaraty. ${ }^{618}$

Seu trabalho apontou que a aproximação de Vargas com Perón lhe rendeu muitos problemas em termos de política interna. Em suas palavras, "a identificação

\footnotetext{
${ }^{614}$ Ibidem, p. 30.

${ }^{615}$ Ibidem, p. 168.

${ }^{616}$ Ibidem, p.72.

${ }^{617}$ CAVLAK, op. cit., p. 196-197.

618 SANTOS, Daniella Xavier. Vargas e Perón: A Política Externa do Brasil para a Argentina na Primeira Metade da Década de 1950. Dissertação de mestrado. Universidade de Brasília, 1991, p. 82
} 
ideológica com Perón era algo que Vargas precisava manejar com muito cuidado", pois isso "assustava a opinião pública brasileira que, insuflada pela imprensa oposicionista, não confiava em que o Presidente argentino houvesse abandonado, de um todo, suas pretensões imperialistas". ${ }^{619}$ Partindo da análise dos múltiplos fatores envolvidos no período, concluiu a autora:

Nem o Brasil, nem a comunidade latino-americana estavam preparados para uma união daquele tipo [Pacto $A B C$ ]. [...] Naquele momento e em consequência das desconfianças que a sua figura [Perón] despertava, não existiram as condições necessárias para que estas [iniciativas de cooperação] fossem consideradas. ${ }^{620}$

\subsection{O depoimento de João Neves e o pedido de impeachment}

O assunto dos diálogos secretos com Perón, que caminhava lentamente para o esquecimento público, ressurgiu com força a partir de 4 de abril de 1954, quando o exchanceler João Neves da Fontoura publicou um longo depoimento no jornal $O$ Globo, rapidamente reproduzido em outros meios de comunicação.

Gaúcho e amigo de Vargas desde os tempos em que ambos eram estudantes universitários, João Neves da Fontoura teve um relacionamento marcado por idas e vindas políticas com este. Em 1930, foi um dos principais líderes do movimento armado que levou à derrubada do governo Washington Luís. No entanto, dois anos depois, teve de se exilar na Argentina após apoiar a Revolução Constitucionalista paulista. Em 1935, foi eleito deputado federal e respaldou em seguida o Estado Novo, tendo exercido o cargo de embaixador em Portugal entre 1943 e 1945. Filiado ao PSD, apoiou a eleição de Dutra em 1946 e, posteriormente, foi coordenador geral da campanha presidencial vitoriosa de Vargas em 1950. Em três anos como ministro das Relações Exteriores (1951-1953), defendeu principalmente o alinhamento em relação aos Estados Unidos, linha que considerava tradição diplomática do País.

Em 1954, rompido novamente com Vargas após sua saída do Itamaraty, Neves disse em seu depoimento acreditar que o discurso de Perón era autêntico, dado seu "flagrante parentesco" com as ideias proferidas pelo líder justicialista em outras ocasiões. Reafirmou a defesa do ideal pan-americano e assegurou: "O Brasil não está interessado na formação de quaisquer blocos regionais nem no estabelecimento de

\footnotetext{
${ }^{619}$ Ibidem, p. 59.

${ }^{620}$ Idem.
} 
facções continentais em detrimento do conjunto". ${ }^{621}$ Considerou ainda a proposta do ABC um "triste anacronismo" 622 e um "pobre cavalo de Troya [...] dentro do qual o justicialismo esperava montar a máquina dos planos alucinados do Grupo dos Oficiais Unidos". 623

De acordo com Neves, emissários justicialistas procuraram com afoiteza a “integração" desde o início do governo Vargas. Esse "açodamento ostentoso" o fizera desconfiar de "conversações ou insinuações anteriores ao pleito de 1950, as quais o general Perón queria cautelosamente converter em títulos à vista" ${ }^{624}$ No entanto, a parte mais importante do seu depoimento estava nas possíveis implicações do presidente brasileiro em "uma visível conjura no sentido de levar-nos para o lado do justicialismo peronista". ${ }^{625}$ Segundo João Neves da Fontoura, por três anos "não pararam as laçadeiras, tecendo entre as duas capitais [Rio de Janeiro e Buenos Aires] os fios de uma intriga internacional". ${ }^{626}$ Nesse processo, Vargas teria colaborado, no mínimo, com uma "negligente cumplicidade". ${ }^{627}$

O ex-chanceler citou diversos episódios que o levaram a tais suspeitas. Entre outros, lembrou que no início de 1952 João Goulart o procurara para falar sobre seus encontros com Perón e para reclamar da pouca atenção dada pelo governo aos vizinhos argentinos. E completou: "Tudo isso o jovem líder trabalhista me foi recitando entre louvores ao prestígio do general Perón perante as massas populares do seu país". ${ }^{628}$ Em outra ocasião, ouvira inadvertidamente de uma secretaria do chefe da Casa Civil que "o diretor do jornal peronista no Brasil" (provavelmente Geraldo Rocha, proprietário de $O$ Mundo) necessitava entregar uma carta do mandatário argentino a Vargas. Neves conjecturou ainda sobre missivas secretas oriundas de Buenos Aires envolvendo Lusardo, a quem criticou por seus "excessos de amizade com o General Perón". ${ }^{629}$

A partir desses elementos, defendeu a publicação da correspondência entre os dois presidentes para acabar com o "mundo de insinuações e suspeitas acerca da sua conduta [de Vargas] neste delicado passo da vida continental". Sobre tais cartas,

\footnotetext{
${ }^{621}$ FONTOURA, João Neves da. Depoimentos de um ex-ministro (peronismo - minerais atómicos política externa). Rio de Janeiro, Organização Simões Editora, 1957, p. 46.

${ }^{622}$ Ibidem, p. 54.

${ }^{623}$ Ibidem, p. 55.

${ }^{624}$ Ibidem, p. 23.

${ }^{625}$ Ibidem, p. 35.

${ }^{626}$ Ibidem, p. 44.

${ }^{627}$ Ibidem, p. 44.

${ }^{628}$ Ibidem, p. 36.

${ }^{629}$ Ibidem, p. 51.
} 
assegurou que não as tinha lido, mas que não duvidava de sua existência. E fustigou: "Nada mais censurável e estranho dois Chefes de Estado trocarem cartas, sobre política externa, por cima e à revelia dos canais diplomáticos". 630

Apesar das fortes suspeitas, João Neves da Fontoura admitiu em um trecho a fragilidade documental do seu depoimento:

Falando honestamente, não tenho nem poderia ter prova documental de que o Sr. Getúlio Vargas se haja antecipadamente comprometido com o General Perón a incluir o Brasil no plano da Confederação Latino-Americana, habilmente disfarçada sob o rótulo de "integração econômica". ${ }^{631}$

Desta vez, a reação do governo foi mais rápida. No dia seguinte, Lourival Fontes, chefe do Gabinete Civil da Presidência da República, saiu em sua defesa. Assegurou que o presidente era um reconhecido nacionalista e respeitador da Constituição: "Não estamos mais na época da diplomacia secreta. Nem o sr. Getúlio Vargas tinha poderes ditatoriais para celebrar tratados à revelia dos órgãos constitucionais". Emendou, em seguida:

\begin{abstract}
A dialética do meu caro amigo João Neves da Fontoura perdeu-se em fantasias, seguiu por veredas enganosas, envenenou as fontes da verdade, impregnando o seu depoimento de subterfúgios e insinuações. Não há nele um fato real, uma afirmação positiva, um prova concreta, um subsídio documental envolvendo a responsabilidade do presidente Getúlio Vargas. Há, sim, um tom folhatinesco de novela policial, onde entram personagens pelas portas do fundo, agentes embuçados e outros sinistros comparsas desse gênero de ficção. O que é lamentável em tudo isso - e digo com pena - é ver que o ex-chanceler fez desertar do Itamaraty a prudência, a reserva e a discrição. ${ }^{632}$
\end{abstract}

Alegando ser conhecedor da correspondência entre os dois presidentes, o chefe da Casa Civil garantiu que as missivas não passavam de meras "cartas de cortesia recíproca”. Embora se colocasse contra a divulgação desse material, garantiu que, caso isso ocorresse, "seriam varridos todos esses duendes e fantasmas que o ministro João Neves espalhou no seu depoimento". Em sua perspectiva, a concessão a Perón do direito de representação dos interesses brasileiros era uma "historieta inverossímil", que enveredava pelo "reino da fábula".

\footnotetext{
${ }^{630}$ Ibidem, p. 34.

${ }^{631}$ Ibidem, p. 22.

${ }^{632}$ CRUZ, Adelina Novaes e; COSTA, Celia Maria Leite; D’ARAÙJO, Maria Celina Soares; SILVA, Suely Braga da (orgs.). Impasse na democracia brasileira (1951-1955): Coletânea de documentos. Rio de Janeiro: Fundação Getúlio Vargas, 1983, p. 267.
} 
Lourival Fontes reafirmou ainda a "fidelidade ao pan-americanismo" do presidente e sua disposição em "não aprisionar o Brasil em blocos regionais ou alianças de nações". Em relação ao suposto financiamento da campanha de 1950, recordou que João Neves fora o presidente do Comitê de pré-candidatura de Vargas e redarguiu: "Ninguém melhor do que ele poderá testemunhar que nunca obtivemos recursos e nunca recebemos influências de qualquer grupo ou país estrangeiro". Ao final, asseverou que em relação à política externa "o Brasil nada tem do que se envergonhar e tudo tem do que se orgulhar".

A resposta não foi suficiente para aplacar uma nova onda de ataques. Com João Goulart longe dos holofotes, Lacerda, em especial, não perdeu a oportunidade de investir ferozmente contra o presidente. Garantiu que "no que tange ao sr. Getúlio Vargas, o Brasil se envergonha profundamente de tê-lo como Presidente da República. Nunca um presidente envergonhou tanto - e se envergonhou tão pouco". ${ }^{633}$ As alegações de João Neves confirmariam o conluio, definido por ele como a "página mais ignóbil da vida internacional deste país que tem, na Presidência da República, um aventureiro". ${ }^{634} \mathrm{O}$ jornalista fluminense classificou também as conversas secretas como uma “conjura vergonhosa de seus dois dirigentes, [feita] à revelia dos dois povos, traficando com a honra nacional respectiva e a estabilidade da paz entre as nações de todo um continente". ${ }^{635}$ Sobre a falta de provas documentais, confessada por João Neves da Fontoura, redarguiu:

\begin{abstract}
Em matéria política e diplomática, as provas são indiciais, circunstanciais, raramente podem ser inteiramente documentadas. Nem sempre é possível fotografar o sr. João Goulart no momento em que pedia ao sr. João Neves que concordasse em levar o Brasil para uma "integração" com a Argentina peronista [...] Exigir, pois, provas dessa ordem é condenar uma Nação a ficar indefesa diante daqueles que deliberadamente a estão traindo.

Quem trai geralmente não deixa prova documental de sua traição $[\ldots]^{636}$
\end{abstract}

Lacerda criticou ainda a explícita vontade do governo em colocar uma pedra sobre o assunto. Escreveu ele: “A conduta do sr. Getúlio Vargas enoja até ele próprio obrigando-o a silenciar. E o pior é que, na forma do costume, ele apenas espera que a

\footnotetext{
${ }^{633}$ LACERDA, Carlos. "A desagregação do governo" In Tribuna da Imprensa. Rio de Janeiro, 7 de abril de 1954, p. 4.

${ }^{634}$ LACERDA, Carlos. "Um grande depoimento" In Tribuna da Imprensa, Rio de Janeiro, 3-4 de abril de 1954, p. 4.

${ }^{635}$ LACERDA, Carlos. "A desagregação do governo" In Tribuna da Imprensa. Rio de Janeiro, 7 de abril de 1954, p. 4.

${ }^{636}$ LACERDA, Carlos. "Como se prova que o discurso é autêntico" In Tribuna da Imprensa, Rio de Janeiro, 09/04/1954, p. 4.
} 
Nação tire a mão do nariz - para continuar a cheirar mal. O Governo está podre. A sua podridão já passou da fronteira". 637

Invocando o período do Estado Novo, no qual Lourival Fontes fora diretor do Departamento de Imprensa e Propaganda (DIP), apelidou-o de "antigo dr. Goebbels", em referência ao ministro da Propaganda do Terceiro Reich. ${ }^{638}$ Classificou a defesa do governo Vargas como mais uma "pêta da propaganda totalitária, em que se especializou o homem do DIP". 639

A situação política de Vargas era realmente preocupante. Em uma charge do período publicada na revista Careta, Vargas aparece sentado sobre uma cama de pregos em trajes indianos. Ao seu lado, o personagem Jeca questiona o presidente: "Como se arranjou vosmincê[sic] com o depoimento de João Neves?". Ao que Vargas redargui: “Ora, Jeca! Um prego a mais, um a menos...”. A resposta reflete bem as complicações políticas que se avolumavam naqueles meses. ${ }^{640}$

No Congresso, udenistas já falavam no impeachment no dia seguinte à publicação do testemunho de João Neves da Fontoura. ${ }^{641}$ Durante o mês de abril, a oposição fez pressão na Câmara dos Deputados para convocar o presidente, ou pelo menos o novo ministro das Relações Exteriores, a responder sobre questões relativas à controvérsia. ${ }^{642}$ Não houve sucesso.

Acuado politicamente, Vargas fez, no dia $1^{\circ}$ de maio, um pronunciamento enérgico no rádio, em que elogiou a atuação dos sindicatos e do ex-ministro João Goulart. $\mathrm{Na}$ ocasião, ele surpreendeu ao anunciar o aumento do salário mínimo em $100 \%$, justamente uma das propostas mais criticadas pelo "Manifesto dos Coronéis". A ação teve enorme repercussão e, em alguns casos, as críticas de parlamentares e jornalistas conservadores buscaram associar o gesto ao governo argentino.

Para o senador udenista Hamilton Nogueira, a fala presidencial seguia a "linha justicialista-demagógica". ${ }^{643}$ Já Lacerda viu na medida uma tentativa varguista de recuperar prestígio após o recente escândalo. Em suas palavras, "quando a nação inteira

\footnotetext{
${ }^{637}$ LACERDA, Carlos. "Análise de um falso testemunho" In Tribunda da Imprensa, Rio de Janeiro, 6 de abril de 1954, p. 4.

${ }^{638}$ LACERDA, Carlos. “A desagregação do governo” In Tribuna da Imprensa. Rio de Janeiro, 7 de abril de 1954, p. 4.

${ }^{639}$ Idem.

${ }^{640}$ Careta, Rio de Janeiro, v. 46, número 2393, 8/5/1954 apud CRUZ, op. cit., p. 326.

641 “Alta traição” In Tribuna da Imprensa, Rio de Janeiro, 5/4/1954, p. 1.

${ }^{642}$ CRUZ, op. cit., p. 271-272. Ver também: “A oposição exige Getúlio na Câmara” In Tribuna da Imprensa, Rio de Janeiro, 6 de abril de 1954, p. 1 e 2.

643 "Justicialista, a fala presidencial do dia $1^{\text {o" }}$ In Tribuna da Imprensa, 8-9/05/1954, p. 4.
} 
se vê traída, ele [Vargas] trata de comprar o apoio dos trabalhadores com benefícios que, normalmente devem ser proporcionados sem propaganda [...]". 644

Segundo outro correligionário udenista, o vereador carioca Mário Martins, tratava-se de mais uma "peronada":

É fácil comprovar - disse o vereador - que homens que lidam diretamente
com o general Perón, como é o caso do ex-ministro João Goulart, passam a
usar a mesma tática observada na Argentina: criar dificuldades para, depois,
estabelecer um salário, não um salário-mínimo, mas um salário eleitoral.
[...] Tudo isso está de acordo com a peronada que Getúlio e Jango planejam
contra o Brasil. Procuram, assim, provocar maior inquietude, para depois,
explorando os sentimentos do povo, explorando suas necessidades, encontrar
campo para nova demagogia social. ${ }^{645}$

Apenas 48 horas após o anúncio do novo salário mínimo, Wilson Leite Passos, um estudante de ligações com a UDN, protocolou no Congresso um pedido de impeachment de Vargas, aproveitando-se que a Constituição facultava tal possibilidade. A denúncia baseou-se em dois aspectos principais. O primeiro alegava que o presidente acertara a formação do Pacto $A B C$ "em condições e bases desconhecidas e que podem ter sido ajustadas visando tão somente a fins pessoais de perpetuação no poder, contrariamente à dignidade e aos interesses nacionais". ${ }^{646} \mathrm{O}$ segundo relacionava-se a uma série de acusações envolvendo improbidade administrativa e crimes de responsabilidade ligados à má execução orçamentária. ${ }^{647}$

O deputado petebista Viera Lins, relator do processo, recomendou o arquivamento imediato da denúncia. Considerou a acusação envolvendo o ABC "destituída de fundamento" e alegou que "tudo não passa de conjecturas e de elucubrações sem qualquer base real". ${ }^{648}$ Ainda assim, o impeachment acabou submetido ao plenário da Câmara dos Deputados, a partir de 2 de junho.

A UDN e outros partidos de oposição menores sabiam que tinham pouquíssimas chances de vitória. Na Tribuna da Imprensa, afirmou-se em uma coluna não assinada: "Ninguém está iludido quanto à possibilidade de virem os deputados a decretar a medida [...]. Para evitar isto, dispõe ele [presidente] de uma maioria cabisbaixa e obediente". ${ }^{649}$ Sequer havia consenso entre os oposicionistas em torno do impeachment.

\footnotetext{
644 "Peronada de Getúlio o aumento do salário" In Tribuna da Imprensa, Rio de Janeiro, 12/05/1954, p. 8, $1^{\circ}$ caderno.

${ }^{645}$ Idem.

${ }^{646}$ CRUZ, op. cit., p. 275-279.

${ }^{647}$ Idem.

${ }^{648}$ Idem

${ }^{649}$ Opinião [Coluna] In Tribuna da Imprensa. Rio de Janeiro, 17/05/1954, p. 4.
} 
Para o deputado pessedista Armando Falcão, o gesto favorecia Vargas, sendo preferível "policiá-lo no Congresso a transformá-lo de novo no ídolo de S. Borja". 650

Isso, no entanto, não impediu que alguns membros da UDN defendessem a ação com unhas e dentes. Para Lacerda, o importante era acuar ainda mais o governo para que o presidente tivesse "os dentes quebrados - no sentido figurado, é claro". Ele atacou:

\begin{abstract}
ANDA cheio de medo, mais do que de costume, o sr. Getúlio Vargas. Quem sabe dá o azar e a Oposição faz maioria, para afastá-lo do poder, a fim de ser julgado por seus crimes?

Como tudo que lhe interessa é ficar no poder, mesmo num poder degradado, tratemos de tranquilizá-lo. Não é de crer que a Oposição faça maioria [...]

O seu governo imoral poderá continuar, até o fim, a fingir de governo legal.

Mas esta espécie de pacto de desonra entre o Governo e a Nação só não atingirá mais profundamente o destino da democracia e os interesses permanentes do Brasil se o sr. Getúlio Vargas tiver os dentes quebrados - no sentido figurado, é claro.

Se ele fica no poder com vagar e oportunidade para intrigar, dividir, comprar, insultar, mentir, fazer a demagogia que o Banco do Brasil custeia, a pusilanimidade de alguns e a cobiça de outros toleram e propagam, não há nada mais fácil de prever do que uma nova ditadura - ou a guerra civil.

O destino melancólico desse homem fatídico é derramar sangue de brasileiros para chegar ou ficar no Palácio do Catete.

Por isto, é bom que esteja acuado. É excelente que a Câmara esteja treinando o povo para a Democracia, com o debate sobre o "impeachment". Em primeiro lugar, porque assim a própria Câmara fica sabendo o que vem a ser essa penicilina constitucional para a infecção que é o Governo Vargas. [...]

Não importa que, no final, como todos já sabem e esperam, não haja "impeachment". O que importa é o debate, para informar o povo, esclarecê-lo cada vez mais - e acuar o Governo, obrigando-o a defender-se, já que não se pode obrigá-lo a ser honrado e decente. ${ }^{651}$
\end{abstract}

Em suas memórias, o líder udenista Afonso Arinos recordou que um dos defensores mais intransigentes do pedido de impeachment foi o brigadeiro Eduardo Gomes, derrotado em dois pleitos presidenciais consecutivos. Ao contestar que a batalha muito provavelmente seria perdida e que, dessa forma, Vargas poderia ganhar terreno momentaneamente, Arinos escutou deste que a vitória temporária do líder gaúcho pouco importava. "Isso [a derrota do impeachment] é necessário para que se forme, no meio militar, a consciência de que não há solução legal”, assegurou Eduardo Gomes. Ou seja, o esgotamento das tentativas constitucionais de derrubar o governo seria uma forma de fortalecer entre os oficiais o projeto de intervenção armada. "Aí entendi o jogo", relembrou Arinos. ${ }^{652}$

\footnotetext{
650 "Vargas deve ser tolerado até o fim" In Tribuna da Imprensa, Rio de Janeiro, 15/6/1954, p. 3

${ }^{651}$ LACERDA, Carlos.”Impeachment, treinamento democrático" In Tribuna da Imprensa, Rio de Janeiro, 9/6/1954, p.4.

${ }^{652}$ NETO, op. cit., p. 284.
} 
Ao contrário dos udenistas, o general Dutra se opôs ao impeachment e arrastou consigo parte do PSD. ${ }^{653}$ Após duas semanas de debates, a Câmara dos Deputados colocou o assunto em votação em 16 de junho. A vitória do governo ocorreu com uma margem maior do que a esperada, com 135 votos contra o impeachment e apenas 36 favoráveis. Para a Tribuna da Imprensa, tratava-se de "estrondosa vitória" do governo. O jornal acusou dezenas de deputados udenistas de traição, alegando que seis haviam votado contra a medida e quarenta não apareceram por estarem escondidos nos corredores. No dia seguinte, publicou uma lista acusatória completa desses parlamentares. ${ }^{654}$

Destoando do tom do jornal, o udenista Afonso Arinos parecia satisfeito: "Os objetivos principais foram alcançados. O importante era advertir o sr. Getúlio Vargas de que, se tentar o golpe ou qualquer outra perturbação da ordem, encontrará pela frente uma oposição em qualquer terreno". 655

Menos de dois meses depois, em 5 de agosto de 1954, um texto não assinado do Correio da Manhã anunciava: "Peronada à vista". De acordo com o jornal, Vargas continuava com sua "ânsia de poder ditatorial" e teria estabelecido "uma cadeia de conspiração que se articula no subsolo do Catete". Haveria um "plano engenhoso", que passaria pela vitória petebista nas eleições parlamentares seguintes para, em seguida, mudar a Constituição e garantir a reeleição presidencial, nos moldes do que havia sido feito em 1949 na Argentina. Como se vê, trata-se de malabarismo discursivo semelhante ao praticado por Lacerda há anos para justificar o golpismo. Comentou o jornal de propriedade de Paulo Bittencourt:

Tudo é tão medíocre, tão indigente de originalidade no getulismo que até os projetos de ditadura hão de ser importados. Em 1937, as idéias e o processo do golpe foram trazidos da Alemanha e da Itália; agora, o modelo virá, junto com o trigo, do seu vizinho e mestre Perón. [...] Este é o plano também que se articula agora no Catete: um golpe branco, com aparência "legal", dispensando o sr. Getúlio Vargas de fazer apelo às classes armadas como da vez anterior. Durante este ano, o governo consumará o processo da ditadura econômica para a corrupção e a intimidação nas eleições estaduais. No próximo ano, conta o Catete que as bancadas parlamentares lhe entregarão um Congresso submisso para a reforma constitucional, com a "república sindicalista" e o direito de reeleição do presidente da República. ${ }^{656}$

\footnotetext{
${ }^{653}$ DULLES, op. cit, p. 168.

${ }^{654}$ MELO FILHO, Murilo. ““Impeachment”: traição de dezenas de udenistas” In Tribuna da Imprensa, Rio de Janeiro, 17/6/1954, p. 1 e 3.

655 "Atingidos os objetivos" In Tribuna da Imprensa, Rio de Janeiro, 17/6/1954, p. 3.

656 "Peronada à vista" in Correio da Manhã, Rio de Janeiro, 5 de agosto de 1954, p. 4, $1^{\circ}$ caderno.
} 
Na última linha desse editorial, podia-se ler uma advertência: "Mas isto não aconteceu, nem acontecerá. Esta peronada à vista vai encontrar pela frente uma reação firme e indomável”.

Antes de chegar à página quatro, onde foi publicado esse texto, os leitores do Correio da Manhã daquele mesmo dia provavelmente tiveram seus olhos atraídos pela manchete da primeira página: na madrugada anterior, Carlos Lacerda sofrera um atentado quando chegava ao seu apartamento na rua Tonelero, bairro de Copacabana. Como se sabe, tal episódio deu o argumento final para que os golpistas entrassem em cena de maneira mais explícita e intercedessem fortemente pela abreviação do governo Vargas.

Nos diversos jornais estatais de Buenos Aires a carta-testamento do político gaúcho foi intensamente veiculada e a culpa pela morte de Vargas, tido como "um justicialista", foi atribuída principalmente ao imperialismo norte-americano. ${ }^{657}$ Mais contido, um informe reservado da Embaixada argentina no Rio da Janeiro comunicou à Casa Rosada:

[...] com um ato tão teatral, o dr. Vargas servia a seus interesses e convertia a derrota em uma vitória futura sobre seus inimigos. O primeiro mandatário, conhecedor da índole sentimental e impressionável de seu povo, mediu o alcance do suicídio e das acusações deixadas na carta póstuma.

A repercussão foi notável. ${ }^{658}$

Embora tenha criado muitas dificuldades ao governo, o caso Perón não forneceu, como o atentado a Lacerda, o argumento definitivo para derrubá-lo. Uma nova tentativa de conseguir uma prova cabal que vinculasse os petebistas ao justicialismo ocorreria apenas no ano seguinte quando o antiperonismo, em sua vertente conspiratória, atingiu seu ápice no Brasil.

\subsection{A carta Brandi}

A forte comoção que se seguiu à morte de Vargas demonstrou a popularidade do presidente falecido e constrangeu temporariamente os golpistas civis e militares. Horas após o suicídio, o País passou a ser comandado por João Café Filho, vice-presidente de ideias conservadoras. No novo ministério, ocupado principalmente por udenistas,

\footnotetext{
${ }^{657}$ CAVLAK, op. cit., p. 186-187.

${ }^{658}$ Apud ALMEIDA, op. cit., p. 315.
} 
Eduardo Gomes, que articulara a intervenção armada nos meses anteriores, recebeu a pasta da Aeronáutica. O PTB proibiu seus membros de participarem do novo gabinete.

Em vão, a UDN ainda tentou adiar as eleições parlamentares, realizadas apenas quarenta dias após a morte do político gaúcho. Muitos de seus correligionários temiam que o resultado do pleito fosse afetado pelo trágico desfecho da crise e pela insistente divulgação da carta Testamento. Para Lacerda, a missiva não passava de um "novo documento Cohen dos falsários da oligarquia". ${ }^{659}$ Como outros, ele passou a defender um regime de exceção, ou seja, a "suspensão temporária do pleito, até que se promovesse um expurgo completo dos quadros getulistas na administração pública, como elemento indispensável à regeneração da vida política brasileira", 660

Surpreendentemente, a voz das urnas pouco alterou a correlação de forças no Congresso. Embora tenha perdido algumas cadeiras na Câmara dos Deputados, a UDN viu Lacerda ser eleito deputado federal com o maior número de votos do Distrito Federal. João Goulart, por sua vez, foi derrotado no pleito para senador pelo Rio Grande do Sul.

No início do ano seguinte, Café Filho demonstrou publicamente sua proximidade com a alta cúpula militar, formada, em sua maioria, por antigetulistas. Estes defendiam o lançamento de um candidato civil de "união nacional" em chapa única. Todavia, a ideia não encontrou eco nos outros partidos. Em fevereiro, o PSD confirmou a candidatura do governador de Minas Gerais, Juscelino Kubitschek, à presidência. Em abril, um acordo garantiu a vice-presidência ao PTB, que indicou João Goulart.

A aliança imediatamente alarmou os setores antigetulistas, que continuavam organizados depois de agosto de 1954. Temendo uma terceira derrota eleitoral consecutiva da UDN, Lacerda e outros correligionários mais radicais passaram a conclamar por um governo de emergência que suspendesse a Constituição, impedisse as eleições e fizesse uma "reforma da democracia brasileira para instaurar a legalidade legítima". ${ }^{661}$ Tratava-se de um projeto evidentemente contraditório com o tradicional ideal liberal defendido por alguns dos principais membros do partido desde sua fundação.

\footnotetext{
${ }^{659}$ Apud MENDONÇA, op. cit., p. 160.

${ }^{660}$ Ibidem, p. 161.

${ }^{661}$ SKIDMORE, Thomas. Brasil: de Getúlio a Castelo. 7. ed. Rio de Janeiro: Paz e Terra, 1982, p. 185.
} 
Pouco depois, a UDN lançou como candidato o general cearense Juarez Távora, chefe da Casa Civil do governo Café Filho e que também participara das articulações para tirar Vargas do poder no ano anterior. O escolhido, porém, carecia do carisma e do otimismo que abundavam no concorrente mineiro.

Temerosa, parte da imprensa liberal-conservadora passou a atacar violentamente a fórmula J-J (Juscelino e Jango), com acusações que evocavam a insistente representação de uma conspiração envolvendo uma "república sindicalista" e alegações de que o candidato a vice-presidente era um peronista.

Um mês antes das eleições, Luís Carlos Prestes fez um comunicado conclamando os comunistas a votarem em Goulart e Kubistchek, o que ampliou ainda mais as já recorrentes acusações de um conluio entre petebistas e vermelhos. ${ }^{662}$ Cientes dos problemas causados pelo apoio, ambos negaram publicamente um aliança secreta com os comunistas. ${ }^{663}$

Firme em sua disposição de evitar o pleito, Lacerda, em um editorial de junho de 1955, explicitou novamente a necessidade de um regime de exceção:

\begin{abstract}
Os líderes civis são, quase todos, partidários da chamada "solução extralegal", eufemismo covarde para a realidade que é a do indispensável contragolpe para evitar a ascensão dos golpistas, ladrões e protetores de ladrões, ao Poder da República. [...] Protelar o contragolpe, agora, deixandoo para depois das eleições, é ignorar que as eleições, nas condições em que forçosamente se vão efetuar, é que são o golpe! [...] E a prova é que os que mais as desejam, os que mais se esforçam para que elas se realizem são os golpistas de sempre, enquanto os democratas, dia após dia em maior número, reconhecem que para haver democracia no Brasil é preciso dar, agora, o contragolpe decisivo e final no regime golpista em que tem vivido o Brasil desde $1930 .{ }^{664}$
\end{abstract}

Também em junho, a Tribuna da Imprensa noticiou em, primeira página, a existência de "rumores" e "informações não documentadas" sobre tráfico de armas na fronteira entre Brasil e Argentina, especialmente na região da estância de Lusardo, em São Borja. ${ }^{665} \mathrm{Em}$ agosto, a edição do dia 12 teve como manchete principal: "Jango prepara a guerra civil”. Sem citar fontes, o texto, que tampouco trazia assinatura, assegurava que Jango havia retomado seus contatos com Perón e iniciado a importação secreta de armas e munição da Argentina. Sua candidatura contaria com a "assistência

\footnotetext{
${ }^{662}$ DULLES, op. cit., p. 219.

${ }^{663}$ CARLONI, Karla Guilherme. Marechal Lott, a opção das esquerdas: uma biografia política. Rio de Janeiro, Garamond, 2014, p. 114.

${ }^{664}$ Apud MENDONÇA, op. cit., p. 173 (editorial de 29/6/1955).

665 "Importação de armas na fronteira da Argentina” In Tribuna da Imprensa, Rio de Janeiro, 8/6/1955, p. 
técnica" dos justicialistas e apoio dos comunistas, que teriam recebido uma quantia vultosa para ampará-lo. ${ }^{666}$

Apenas dezessete dias antes das eleições, Lacerda exibiu na televisão um documento que supostamente comprovaria as relações entre o candidato à vicepresidência e o regime argentino. No dia seguinte, a Tribuna de Imprensa anunciou com estardalhaço: "Eis a prova da traição de Jango". Na ocasião, o diário apresentou uma suposta carta em espanhol do deputado peronista Antônio Jesus Brandi a João Goulart datada de 5 de agosto de 1953, período em que este era ministro do Trabalho. Coincidentemente, um golpe militar havia derrubado o regime peronista no dia anterior. A manchete ao lado da missiva informava: "Constituído o governo da revolução argentina".

Na polêmica carta, que possuía timbre da Câmara dos Deputados da província de Corrientes, Brandi informava a Goulart sobre a entrega confidencial de "protocolos e recomendações sobre "brigadas de choque operárias"” enviados pelo justicialista Ángel Borlenghi, ministro do Interior. Este acreditava que seria útil a Goulart "aproveitar a experiência obtida na luta sindical argentina". O documento comunicava também que o vice-governador da província de Corrientes, Clementino Forte, havia sido "designado para dirigir todas as atividades de coordenação sindical entre Brasil e Argentina". Por fim, confirmava-se a compra de "mercadoria" na "Fábrica Militar de Córdoba", que chegaria ao Brasil via Uruguaiana "disfarçada de produtos alimentícios". De acordo com o jornal, o documento teria sido apreendido em um hotel do Rio de Janeiro, quando ali estivera seu portador, Ignacio Pinedo.

Na televisão, Lacerda assegurou: "Só trouxe esta carta ao conhecimento público quando me convenci da sua autenticidade”. Em seguida, bradou:

Depois de um documento desses, que mais se pode dizer?

Teremos uma eleição a 3 de outubro e o candidato franco favorito à vicepresidência da República é um homem ligado à quinta-coluna comunista no Brasil.

Como se isso não bastasse tem-se agora a prova evidente da submissão de Jango Goulart a Perón. Será preciso acrescentar mais alguma coisa?

Vamos nos conformar a ver o Brasil governado por conta e ordem de Perón? [...] Não quero ditadura para o Brasil. Mas acho que a crise brasileira exige uma reforma de estrutura completa e urgente que reestabeleça a confiança do povo, criando condições para a democracia no Brasil.

Essa reforma é indispensável e pode ser obtida, dentre outras maneiras, por uma solução extralegal. A ilegalidade em tempo de crise não é a mesma ilegalidade dos tempos normais.

\footnotetext{
666 “Jango prepara a guerra civil” In Tribuna da Imprensa, Rio de Janeiro, 12/8/1955, p. 1
} 
Reivindico plenos poderes para que o governo, durante determinado tempo, execute determinadas tarefas [...]

Vamos permitir a infiltração comunista e peronista em nosso pais, através do próprio vice-presidente da República?

Vamos entregar o Brasil de graça a Perón? Só para que haja eleições? Na Hungria e na Polônia também houve eleições. Nem por isso se impediu que os comunistas tomassem conta desses países. ${ }^{667}$

A denúncia caiu como uma luva sobre os boatos de tráfico de armas na fronteira argentina que vinham sendo publicados há meses. Tribuna da Imprensa destacou a reação de alguns antivarguistas a respeito do "conluio de Jango com Perón para a traição do Brasil". O tom geral foi de prudência. Afonso Arinos, integrante da "Banda de Música” udenista, declarou: “Tudo vai depender da autenticidade do documento [...] Anteriormente existiam referências a isso. Agora, essa publicação é um indício da existência da articulação peronista em certo sindicalismo brasileiro". Outro correligionário, Raimundo Padilha, defendeu a cassação dos direitos políticos de Jango caso atestada a veracidade da carta. Apenas o parlamentar pessedista Lopo Coelho dispensou qualquer prova por crer que apenas o passado de Jango já confirmaria que "sua presença é incompatível com qualquer posto na democracia". 668

${ }^{667}$ LACERDA, Carlos. "Eis a prova da traição de Jango" In Tribuna da Imprensa, Rio de Janeiro, 1718/9/1955, p. 4.

668 “Conluio contra o Brasil”" In Tribuna da Imprensa, Rio de Janeiro, 19/9/1955, p. 1 


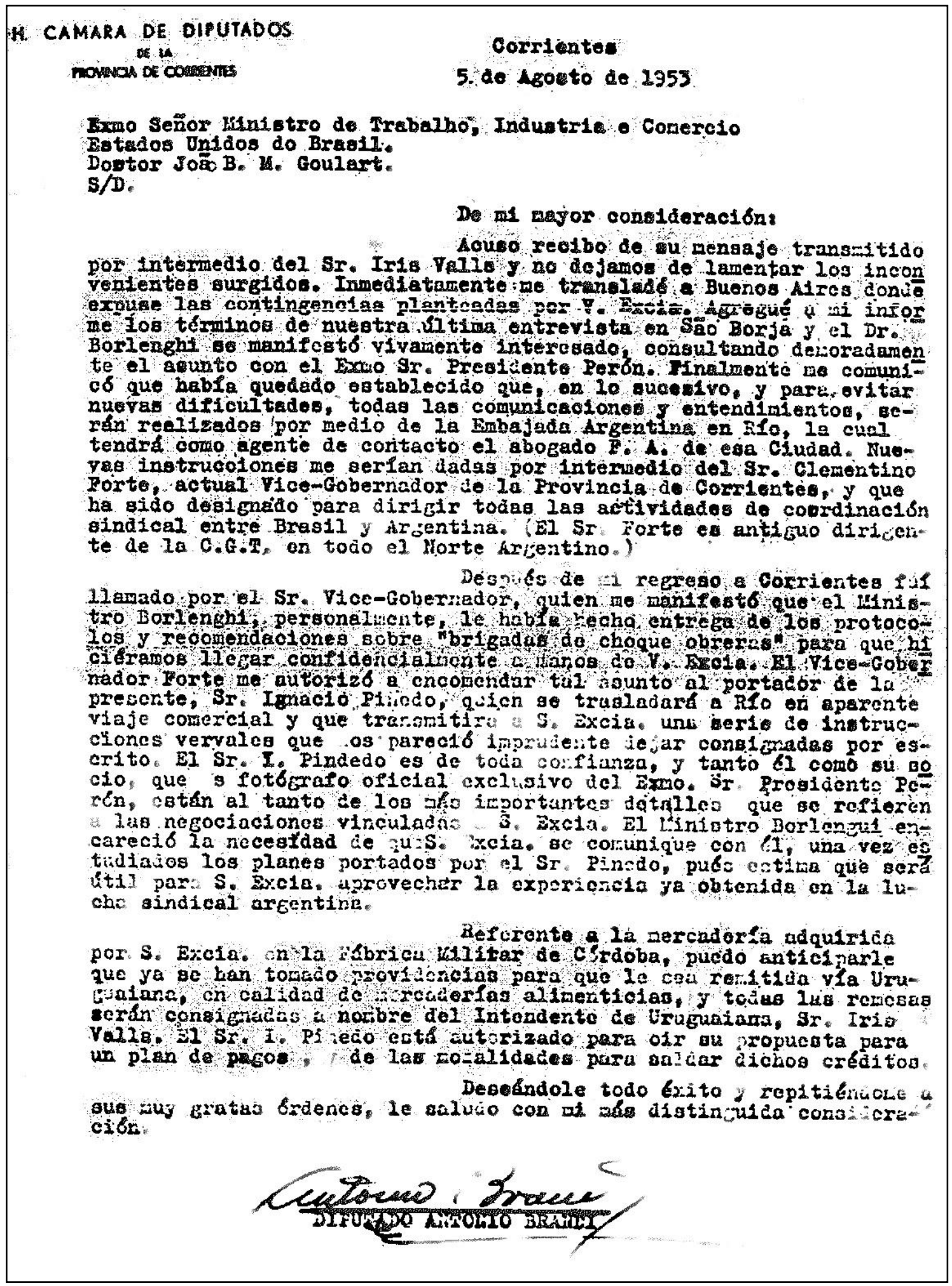

Figura 21 - Fac-símile da carta Brandi publicada em Tribuna da Imprensa. ${ }^{669}$

${ }^{669}$ LACERDA, Carlos. "Eis a prova da traição de Jango" In Tribuna da Imprensa, Rio de Janeiro, 1718/9/1955, p. 1. 
Demonstrando expectativa com a novidade, Hilde Weber publicou uma charge associando diversos políticos locais a Perón (figura 22). Podem ser identificados, da esquerda para direita: Luís Carlos Prestes (secretário-geral do PCB, na ilegalidade), Oswaldo Aranha (velho aliado de Vargas e seu ex-Ministro da Fazenda), Ernani do Amaral Peixoto (presidente do PSD fluminense, ex-governador do Rio de Janeiro e marido de Alzira Vargas) ${ }^{670}$, Juscelino Kubistchek (candidato à presidência pelo PSD) e João Goulart. Abaixo está o presidente argentino, recentemente derrubado.

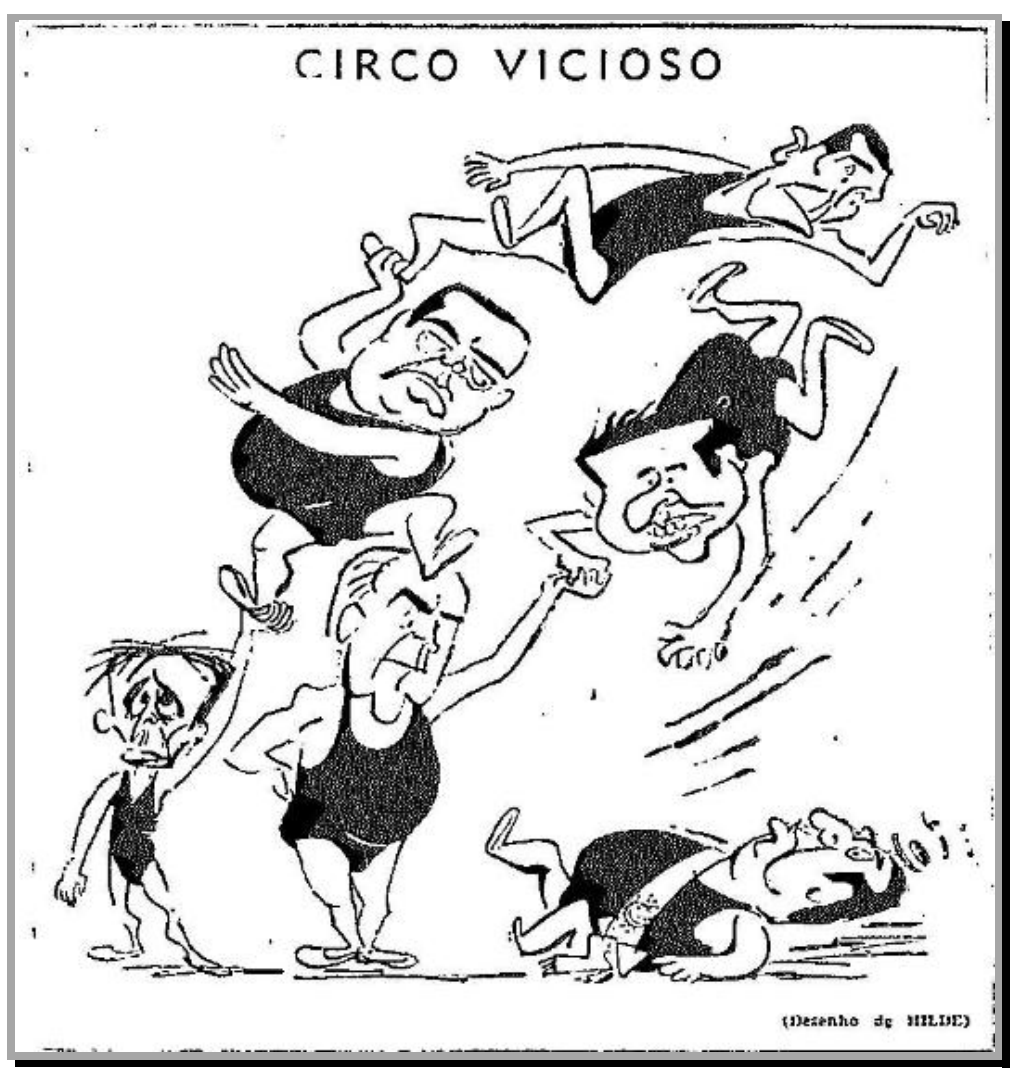

Figura 22 - HILDE. Tribuna da Imprensa, 29/9/1955, p. 4

A imagem apresentou-os como malabaristas uniformizados de um mesmo espetáculo degradante ("circo vicioso"). Tendo em vista os acontecimentos recentes, a charge parece jactar-se do possível enfraquecimento de tais homens públicos que estavam direta ou indiretamente ligados à fórmula J-J (Juscelino-Jango). Eles seriam elos de uma mesma cadeia que teria começado a desmoronar a partir da destituição do líder platino e da veiculação da carta Brandi.

\footnotetext{
${ }^{670}$ Existe também a possibilidade de que esse personagem da cena seja Lutero Vargas, filho do político gaúcho e presidente do diretório carioca do PTB.
} 
O próximo a se estatelar politicamente seria Jango, implicado diretamente na carta Brandi. Sua inevitável derrocada acabaria por atingir também o candidato à presidência, Juscelino, e assim sucessivamente. É importante notar que o baixinho e franzino Prestes novamente desempenha papel discreto na cena, já que os comunistas seguiam sem direitos políticos.

A pedido de parlamentares do próprio PTB, foi criado nos dias seguintes um inquérito policial militar (IPM) para apurar a autenticidade do documento, sob responsabilidade de Emílio Maurell Filho, secretário geral do Ministério da Guerra. Nesse ínterim, aliados de João Goulart levantaram muitas dúvidas sobre o documento, a começar pela sua origem. Desde o início, Lacerda protegeu suas fontes e não esclareceu de que modo o obtivera. Alegou simplesmente que ele fora apreendido, sem dizer por quem, nem quando.

Outras objeções levaram em conta diversos aspectos internos da missiva, que, apesar de supostamente secreta, apresentava conteúdo puerilmente explícito em relação às atividades criminosas. ${ }^{671}$ Chamava atenção que apenas um dos indivíduos citados tenha sido poupado, ao ser mencionado pelas iniciais F.A.. ${ }^{672}$ Todos os outros tiveram seus nomes abertamente apresentados. Com efeito, o conteúdo excessivamente compreensivo soou como uma tentativa deliberada de comprometer os citados, especialmente João Goulart.

Estranhou-se também a grafia correta de palavras como "João" e "São", pois nas máquinas de escrever em língua espanhola predomina o til em uma única tecla, o "ñn". Lacerda redarguiu mostrando uma máquina usada nos países vizinhos em que o til aparecia isolado em uma única tecla, separada do "n". Ele tripudiou: "Vai mal o sr. Juan [sic] Goulart se confia apenas nesse til para salvar-se". ${ }^{673}$ Havia ainda outros erros ortográficos que levantaram a desconfiança de que o documento possivelmente fora escrito por um lusófono. Ao invés de "trasladé”, grafia correta em espanhol, constava a palavra "transladé". "Pues" aparece com um estranho acento: "pués". E o nome do ministro do Interior, Ángel Borlenghi, foi grafado uma vez como "Borlengui". Em um debate parlamentar, o deputado federal Nelson Omegna (PTB-SP) chamou o documento

\footnotetext{
671 “Urgência no inquérito sobre a carta de Jango" In Tribuna da Imprensa, Rio de Janeiro, 20/9/1955, p. 3.

${ }^{672}$ Soube-se depois que tratava-se do advogado Fortunato Azulay. Cordero tentou em vão convencer Lacerda e alguns policiais a fazer um batida policial não oficial na casa dele para buscar novos documentos. Seu objetivo era aproveitar-se da situação para resgatar, na casa de Azulay, provas que o incriminavam em outros episódios envolvendo estelionato.

673 “Termina aqui o caso do til” In Tribuna da Imprensa, Rio de Janeiro, 23/09/1955, p. 1
} 
de "carta-chantagem". ${ }^{674}$ Igualmente, parecia muito suspeito que algo tão comprometedor para Jango, datado de agosto de 1953, viesse a público duas semanas antes das eleições nas quais ele era favorito.

À sua maneira, Lacerda buscou rebater cada um dos pontos levantados e definiu os argumentos dos adversários como "torcicolos, são contorções da verdade para esconder o medo, o grande medo de que estão possuídos". ${ }^{675} \mathrm{Em}$ defesa da carta, o jornalista João Duarte Filho argumentou que Brandi, como correntino, era um personagem fronteiriço, que poderia inconscientemente ter usado a linguagem híbrida que predominaria na região. Além disso, em sua perspectiva, apenas um argentino cometeria tais erros ao escrever despreocupadamente, pois um estrangeiro estaria sempre alerta com uma língua que não é a sua. ${ }^{676}$ Para Lacerda, era um absurdo "exigir de um pobre deputado provincial, e ainda por cima peronista, que escreva segundo os moldes clássicos da Espanha". 677

Poucos dias antes do pleito, alguns udenistas acreditavam que apenas um dado novo poderia mudar o cenário de favoritismo da chapa PSD-PTB. Assim, paralelamente à investigação oficial, Lacerda embarcou para Buenos Aires. Na ocasião, atacou: "Jango ia buscar em Buenos Aires armas para a guerra civil. Nós vamos a Buenos Aires tentar obter mais munição para a vitória de Juarez nas eleições". ${ }^{678}$ E aduziu que perseguiria "as provas da traição dos candidatos peronistas, mancomunados com a corrupção e o comunismo $[\ldots] " .679$

Nesse intervalo, o prefeito de Uruguaiana, Iris Valls, apontado como intermediário na missiva, voou até o Rio de Janeiro para desmenti-la. Após classificar Lacerda como "anormal" e uma "figura patológica", afirmou:

Trata-se evidente que esse profissional da calúnia e da injúria que é o sr. Carlos Lacerda, diretor da Tribuna da Imprensa, está servindo a grupos que procuram, através do ódio e da difamação, criar um ambiente de hostilidade, de insegurança e de tumulto, para promover, então, os seus baixos e inconfessáveis projetos de golpe. ${ }^{60}$

\footnotetext{
674 “A infiltração peronista no Brasil” In Tribuna da Imprensa, Rio de Janeiro, 6/10/1955, p. 4 e 6.

${ }^{675}$ LACERDA, Carlos. "As razões de Juan Goulart” In Tribuna da Imprensa, Rio de Janeiro, 23/9/1955, p. 4.

${ }^{676}$ FILHO, João Duarte. “A carta do deputado". Coluna Tribuna Parlamentar In Tribuna da Imprensa, Rio de Janeiro, 23/9/1955, p. 3.

677 "Evitar que aconteça no Brasil a mesma desgraça da Argentina" In Tribuna da Imprensa, Rio de Janeiro, 29/9/1955, p. 4.

678 “Não, Ernani!" In Tribuna da Imprensa, Rio de Janeiro, 23/09/1955, p. 1.

${ }^{679}$ Tribuna da Imprensa, Rio de Janeiro, 23/09/1955, p. 1.

680 "Fala Valls sobre a carta da traição" In Tribuna da Imprensa, Rio de Janeiro, 23/9/1955, p. 4.
} 
No dia seguinte, a réplica veio em um editorial repleto de ofensas, quando o jornalista fluminense definiu o prefeito gaúcho como "valiente [sic] de costas quentes, primário, ignorante, com certa esperteza de fronteiriço impudente e impune, contrabandista nas horas vagas [...]”. ${ }^{681} \mathrm{Na}$ mesma edição, publicou-se em primeira página a manchete: "Valls deu desfalque na COFAP: CR\$ 1 milhão". ${ }^{62}$

$\mathrm{Na}$ capital argentina, Lacerda conseguiu localizar Ignacio Pinedo, suposto portador da carta secreta. Embora ele negasse qualquer participação nos acontecimentos, admitiu que Brandi era padrinho de um de seus filhos e que conhecia Jango desde menino, embora não fosse seu amigo íntimo. Forneceu também um documento com assinatura do deputado correntino, que pareceu aos olhos de Lacerda de "impressionante identidade" com a que constava na controversa missiva. Foi o suficiente para que o jornal apressadamente estampasse em letras garrafais: "A Tribuna tem as provas da traição de Jango ao Brasil". ${ }^{683}$

Com a queda do justicialismo, foi possível também a Lacerda confirmar que o controvertido discurso de Perón sobre o Pacto $A B C$, que tanta celeuma havia provocado ao final do governo Vargas, era real. ${ }^{684}$ No pronunciamento, vale lembrar, Perón não mencionou João Goulart. A Tribuna da Imprensa classificou-o como "prova insofismável da traição", 685

Em regozijo, João Neves da Fontoura, um dos pivôs daquela discussão no ano anterior, publicou um texto intitulado: "Não há como um dia após o outro" [sic]. Nele, elogiou o "corajoso espírito de iniciativa do deputado Carlos Lacerda" e arremeteu contra "a seita dos 'gregórios", em referência a Gregório Fortunato, chefe da segurança e preso como mandante do atentado da rua Tonelero. Ao contrário do que havia declarado há um ano, disse agora "não acreditar que pessoalmente Vargas houvesse assumido os compromissos que Perón lhe atribui. A este caberá a prova das afirmativas $[\ldots]^{\prime \prime}{ }^{686}$

${ }^{681}$ LACERDA, Carlos. "Fala Iris Falls, o peronista" In Tribuna da Imprensa, Rio de Janeiro, 2425/9/1955, p. 4.

682 "Valls deu desfaque na COFAP: CR\$ 1 milhão" In Tribuna da Imprensa, Rio de Janeiro, 2425/9/1955, p. 1.

${ }^{683}$ LACERDA, Carlos. "A Tribuna tem as provas da traição de Jango ao Brasil” In Tribuna da Imprensa, Rio de Janeiro, 26/9/1955, p. 1. [edição da manhã]

${ }^{684}$ LACERDA, Carlos. "Na Câmara, o discurso de Perón sobre o ABC" In Tribuna da Imprensa, Rio de Janeiro, 29/9/1955, p. 4

685 "Estes fatos também merecem investigação" In Tribuna da Imprensa, Rio de Janeiro, 14-15 de outubro de 1955, p. 1.

${ }^{686}$ FONTOURA, João Neves da "Não há como um dia após o outro" In Tribuna da Imprensa, Rio de Janeiro, 1-2/10/1955, p. 4. 
Alguns dias depois, outro ex-ministro defendeu Vargas no caso das ligações com o peronismo. Na ocasião, o petebista José de Segadas Viana (1906-1991), que estivera à frente da pasta do Trabalho entre setembro de 1951 e junho de 1953, enviou uma carta a Lacerda, a quem se declarou um "admirador". ${ }^{687}$ Nela, assegurou que, em exercício, alertou o presidente a respeito da "gravidade que estava assumindo a infiltração peronista em nosso país", tendo aludido especialmente à atuação dos adidos trabalhistas. Nas suas palavras, o mandatário teria demonstrado "preocupação e até irritação ao saber da interferência dos agentes peronistas na vida sindical brasileira, declarando-me que havia encaminhado uma das exposições de motivo ao Conselho de Segurança Nacional e ao Ministério das Relações Exteriores”.

O magoado ex-ministro, porém, não demonstrou a mesma complacência com seu sucessor, João Goulart. Garantiu que este fora o responsável pelo seu afastamento do ministério, pela greve dos marítimos de 1953 e pela vaia que ele recebera dos trabalhadores nas comemorações de $1^{\circ}$ de maio. Considerou, ainda, "esplêndido" o discurso que Lacerda fizera recentemente na Câmara sobre as ligações entre peronismo e janguismo. ${ }^{688}$

Houve um terceiro homem ligado a Vargas que o defendeu naqueles dias. Em depoimento ao Senado, Lourival Fontes reafirmou que este recebera apenas cinco cartas do presidente platino. Em resposta, teriam sido enviadas missivas lacônicas, com meras manifestações de cortesia mútua. Lourival louvou também a memória do ex-presidente brasileiro como alguém que "nunca transgrediu diante das ameaças ou cedeu à pressão dos interesses". No entanto, confirmou a grande insistência e pressa de Lusardo, exembaixador na Argentina, em acertar um tratado comercial entre os países e fixar um encontro entre os dois mandatários. Desconsiderando o cerne desse depoimento, a Tribuna da Imprensa noticiou-o com a manchete "Luzardo advogava interesses comerciais do governo Perón”. Essa chamada claramente pouco tinha a ver com o conteúdo estrito das declarações de Lourival Fontes. ${ }^{689}$

Não apenas a Última Hora, jornal vinculado ao varguismo, ficou contra a carta Brandi. Diários cariocas de oposição ao trabalhismo, mas defensores da legalidade,

\footnotetext{
${ }^{687}$ A relação entre eles se aprofundaria na década seguinte, quando Viana ocupou o cargo de secretário do Interior e Segurança na gestão de Lacerda como governador da Guanabara (1960-1965).

688 "Segadas Viana confirma acusações contra Jango" In. Tribuna da Imprensa, Rio de Janeiro, 89/10/1955, p. 3. Ver também: "Adidos da Embaixada argentina à frente da propaganda peronista no Brasil” In Correio da Manhã, Rio de Janeiro, 19/06/1955, p. 22.

689 "Luzardo advogava interesses comerciais do governo Perón” In Tribuna da Imprensa, 22-23/10/1955, p. 3
} 
pareciam suspeitar da sua autenticidade. Matutinos como O Jornal, de Assis Chateaubriand, e Correio da Manhã, de Paulo Bittencourt, mobilizaram seus repórteres para conseguir mais informações sobre o caso. Ironicamente, ambos haviam dado muito destaque anteriormente aos boatos sobre relações escusas entre os petebistas e o mandatário argentino. ${ }^{690}$

Lacerda fez questão de recordar isso e, em uma ótica maniqueísta, garantiu que tais meios de comunicação estariam inadvertidamente colocando "sua máquina de difusão a serviço de Jango Goulart [...]". ${ }^{691}$ O Correio da Manhã, em especial, foi acusado de ser "praticante de eunuco no harém de Kubistchek". ${ }^{992}$ Dias depois, Lacerda passou a utilizar a expressão "imprensa perono-janguista" para se referir àqueles que colocavam o documento em dúvida. ${ }^{693}$ Ele fustigou esses donos de jornais:

Tudo por medo ao general Juarez. Até Jango Goulart lhes seve, contanto que não suba ao governo um homem como Juarez Távora. Eles querem é Kubistchek, a reabertura da temporada, o recomeço da safra. Nem que isto lhes custe a própria pele. Pois têm mais amor à bolsa do que à vida. ${ }^{694}$

A quatro dias do pleito, Lacerda assegurou em editorial que apenas a vitória de Juarez Távora e seu vice, Milton Campos, seriam capazes de realizar "a extirpação do peronismo no Brasil". ${ }^{695}$ A Tribuna da Imprensa também reproduziu um discurso do jornalista proferido na Câmara dos Deputados em que ele exortou os brasileiros a "mirar-se no espelho despedaçado da Argentina peronizada para compreender quão perto esteve dessa desgraça e quanto dela se aproximará de novo se não optar na hora exata, com o sentido de gravidade da decisão de cada qual, neste momento da vida brasileira". 696

No entanto, Lacerda já intuía a possibilidade da derrota eleitoral e alegou que estavam para acontecer no Brasil eleições ilegítimas, "parecidas com as que se

\footnotetext{
${ }^{690}$ LACERDA, Carlos. "No fim está o melhor”. Tribuna da Imprensa, Rio de Janeiro, 12/10/1955, p. 4.

${ }^{691}$ LACERDA, Carlos. "O secretário de Jango e os desmentidos que confirmam". Tribuna da Imprensa, Rio de Janeiro, 28/9/1955, p. 4.

${ }^{692}$ LACERDA, Carlos. "No fim está o melhor". Tribuna da Imprensa, Rio de Janeiro, 12/10/1955, p. 4.

693 "Evitar que aconteça no Brasil a mesma desgraça da Argentina". Tribuna da Imprensa, Rio de Janeiro, 29/9/1955, p. 4

${ }^{694}$ LACERDA, Carlos. "Porque se admiram que um traidor tenha traído" In Tribuna da Imprensa, Rio de Janeiro, 30/9/1955, p. 4.

695 "Golpe de silêncio contra a divulgação da verdade" In Tribuna da Imprensa, Rio de Janeiro, 30/9/1955, p. 4.

${ }^{696}$ LACERDA, Carlos. "Na Câmara, o discurso de Perón sobre o ABC" In Tribuna da Imprensa, Rio de Janeiro, 29/9/1955, p. 4
} 
realizavam na Argentina, durante Perón". ${ }^{697}$ No editorial publicado no domingo de eleições foi ainda mais explícito em relação a isso. Em aberta pregação golpista, defendeu que o pleito só deveria ocorrer após a "desintoxicação do país":

PESA sobre o país, no dia de hoje, a ameaça de voltar a um passado de desonra, de manobras inconfessáveis, de corrupção desalmada.

O comício de Kubitschek e Jango foi uma exibição indecorosa desse conluio já agora exposto com insolência, das forças mais detestáveis: o peronismo, com Jango Goulart e seus contrabandistas, o comunismo, revolvendo a vasa social para esculpir a estátua de Kubitschek, o negocismo, preparando o seu retorno triunfal $[\ldots]$

As eleições vão ser fartamente roubadas. Roubadas em si mesmas, roubadas antes de serem feitas, roubadas na apuração. É fraude, e da pior, permitir que concorram às eleições candidatos sabidamente incapacitados, sob o ponto de vista da moral pública, de exercerem os cargos para os quais pleiteiam o voto popular $[\ldots]$

Os que sustentam que, em qualquer hipótese seja qual for o ganhador seja como for a vitória, deve ser dada posse ao vitorioso, ou são imbecis ou estão de má-fé. Pois ninguém, de antemão, pode dizer que o vitorioso deve tomar posse, antes de saber se a vitória foi legítima. O legalismo exige a apuração legal da vitória $[. .$.

Nós, da TRIBUNA DA IMPRENSA temos a consciência tranquila. Até o último momento lutamos para evitar essa eleição feita na fraude e na promiscuidade que a intoxicação da opinião pública favoreceu através de longos anos. Sustentamos que era preciso, primeiro, desintoxicar o país, promover a reforma de certas leis fundamentais, a revisão do registro eleitoral, etc., para depois convocar eleições.

[...] Agora, a sorte está lançada. Seja o que Deus quiser. Só lhe pedimos misericórdia para o Brasil, que vale mais do que os seus homens, e para os nossos filhos, que não têm culpa de ter gente tão medíocre e tão incapaz arcando com a responsabilidade do Poder.

Só Deus, diretamente, poderá inspirar o povo, no dia de hoje. ${ }^{698}$

Enquanto os brasileiros formavam longas filas nos postos de votação, Lacerda, usando os microfones da Rádio Globo, no Rio de Janeiro, transmitiu informações de um telegrama oriundo de Buenos Aires. Em pleno domingo eleitoral, a nota anunciava que um laudo pericial da Polícia Federal argentina, obtido pelo inquérito do general Emílio Maurell Filho, admitira ser "sumamente provável" a autenticidade da assinatura que constava na carta Brandi. Contrariando a legislação eleitoral, que proibia propaganda 48 horas antes do pleito, o jornalista fluminense celebrou entusiasticamente a novidade:

Não estou aqui para fazer propaganda eleitoral. Vim aqui para congratularme com a Nação brasileira pela descoberta, pela comprovação da autenticidade da prova da traição contra ela cometida por determinados indivíduos.

\footnotetext{
697 "Golpe de silêncio contra a divulgação da verdade" In Tribuna da Imprensa, Rio de Janeiro, 30/9/1955, p. 4.

${ }^{698}$ LACERDA, Carlos. "Reflexões na hora de votar" In Tribuna da Imprensa, Rio de Janeiro, 3/10/1955, p. 1
} 
Seria o caso de dizer: bendita benção, que permitiu ao Brasil libertar-se de uma praga e lutar por melhores dias à luz de documentos já agora oficialmente comprovados.

Não posso deixar de agradecer a Deus mais este ato de misericórdia e de infinita bondade para com o Brasil.

Deus Todo-Poderoso, seja para sempre louvado. A Sua Proteção, lá nos céus, velava pela sorte do Brasil, enquanto os homens cá embaixo se dilaceravam no esforço de interdestruição que poderia levar este país à garra [sic]. E eis que a misericórdia de Deus põe em nossas mãos, na hora oportuna - ainda que parecendo tardia - um documento cuja comprovação agora coloca os brasileiros diante de um deve iniludível: o dever de repelir a traição e puni-la dentro da lei, para que a Nação respire, desafogada e tranquila.

É por nossos filhos, é por nossa gente, é por nossa terra, que eu venho à Rádio Globo, congratular-me com a Nação brasileira, com o povo brasileiro e agradecer a Deus, numa prece fervente, pela misericórdia que nos fez, pela graça que nos deu, proporcionando ao Brasil esta oportunidade - talvez única e talvez mesmo derradeira - de comprovar a traição contra ele longamente premeditada e demoradamente consumada e que agora, ainda a tempo, se pode contrarrestar e inutilizar, através da consciência, através dos atos conscientes, através das ações lúcidas patrióticas e inspiradas na misericórdia de Deus para com os filhos desta grande Pátria. ${ }^{699}$

Indagado sobre as implicações políticas da publicação do laudo naquele momento político delicado, o ministro da Guerra, Henrique Teixeira Lott, absteve-se de comentar. ${ }^{700}$ A Tribuna da Imprensa defendeu sua atitude: "Este é um país em que os homens de bem cumprem os seus compromissos: mesmo o de empossar no Governo um traidor da Pátria". ${ }^{701}$ Já a revista $O$ Cruzeiro viu na veiculação da análise uma "indicação preciosa" do estado de espírito dos chefes militares em relação ao presidente do PTB e uma clara "advertência ao eleitorado democrático". 702

Seguiram-se protestos por parte do PTB e do PSD, alegando que a legislação eleitoral havia sido ferida. Em resposta, na Rádio Globo, Lacerda destacou que caso houvesse cometido crime eleitoral "renunciaria às suas imunidades e pagaria gostosamente os 15 dias de prisão estabelecidos pela lei, uma vez que trouxera ao conhecimento do Brasil fatos importantes sobre a traição" que importavam mais do que uma "discussão bizantina" como aquela. ${ }^{703}$ Em um texto não assinado, intitulado "Muito barulho por nada", a Tribuna da Imprensa redarguiu: “A Rádio Globo concitou seus ouvintes a votar contra a corrupção e a ameaça comunista. O PSD e o PTB,

\footnotetext{
699 “A polícia argentina comprova: a Carta de Brandi é autêntica” In Tribuna da Imprensa, Rio de Janeiro, 4/10/1955, p. 1 ( $1^{\circ}$ caderno $)$ e 8 ( $2^{\circ}$. Caderno).

${ }^{700}$ Idem.

701 "Por que Lott divulgou fatos do inquérito Jango-Peronismo" In Tribuna da Imprensa, Rio de Janeiro, 7/10/1951, p. 1.

702 “Coluna Política” In O Cruzeiro, Rio de Janeiro, 15/10/1955.

703 LACERDA, Carlos. "Nenhuma violação à Lei Eleitoral" Tribuna da Imprensa, Rio de Janeiro, 4/10/1955, p. 4.
} 
protestando contra esse fato, revelaram que a carapuça caía em suas cabeças, ao alegar que essa irradiação prejudicava a Juscelino e a Jango". 704

No dia seguinte à eleição, outro artigo não assinado resumiu com riqueza de detalhes o mito da conspiração que vinha se desenvolvendo na imprensa liberalconservadora há anos. $\mathrm{O}$ texto não deixava claras as fontes das informações e misturava dados concretos com boatos para compor uma história aparentemente coerente. De acordo com o artigo, a "traição" se iniciara após as eleições presidenciais de 1950, quando apareceu a possibilidade de o Tribunal Superior Eleitoral aceitar a tese da maioria absoluta e impugnar a posse de Vargas. Caso isso ocorresse, o político gaúcho sublevaria as tropas da $3^{\mathrm{a}}$ e da $5^{\mathrm{a}}$ região militar, sob comando do general Newton Estillac Leal, e transferiria a capital do país para Porto Alegre, onde instalaria o novo ministério. Sob comando de Jango, teria sido estabelecida uma aliança com Perón, que reconheceria imediatamente o novo governo e disponibilizaria tropas para ajudar na marcha armada até o Rio de Janeiro. Embora a ação militar não tenha sido necessária, as boas relações entre os dois presidentes teriam se mantido. Em 1953, Jango teria sido nomeado ministro do Trabalho justamente por pressão de Perón, que buscava intensificar suas relações com o Brasil. Na conclusão, destacou-se:

\begin{abstract}
Jango deslocava-se constantemente para Buenos Aires, em avião pilotado por Fittipaldi e ali passando por cima do Itamarati e da embaixada, mantinha os entendimentos para a traição. Perón recebia o emissário amiúde e com ele sonhava o advento de um novo Rosas, ressuscitado nas águas do Prata para o trono de um vice-reinado que atingia as fronteiras de uma alucinação. ${ }^{705}$
\end{abstract}

Dias depois, dando seguimento às teorias conspiratórias, a Tribuna da Imprensa publicou na sua primeira página mais um artigo sem assinatura. Nele, lia-se: “a guerra pela restauração do peronismo na Argentina será tecida, preparada, mobilizada no Brasil" imediatamente após da chegada de Goulart à vice-presidência. Esse suposto apoio seria uma "contraprestação normal de serviços, um auxílio de aliado, uma retribuição", em se considerando que após as eleições locais de 1950 o mandatário argentino prometera, por intermédio de Jango, ajuda armada para garantir a posse de Vargas. Por essa lógica, empossar Goulart acarretaria restaurar o peronismo no país vizinho. Em outros termos, explicou o jornal:

\footnotetext{
704 "Muito barulho por nada" In Tribuna da Imprensa, Rio de Janeiro, 4/10/1955, p. 1.

705 "Tropas peronistas na retaguarda para garantir a posse de Vargas" In Tribuna da Imprensa, Rio de Janeiro, 4/10/1955, p. 2.
} 
O sócio argentino virá pedir ao sócio brasileiro, agora poderoso e forte, aquele auxílio material que lhe ia dar, quando desfrutava, como um tirano de Roma, a ditadura na Argentina.

O peronismo é que se vai instalar na presidência do Senado brasileiro, quando Jango tomar posse da vice-presidência da República. E vai agir, e vai lutar para a restauração da ditadura argentina". ${ }^{706}$

\subsection{O resultado das eleições e das investigações}

Nos primeiros dias de outubro, houve uma reviravolta no inquérito conduzido pelo general Maurell. Após entrevistar os principais nomes citados na carta Brandi e visitar Buenos Aires, Corrientes e Uruguaiana, ele ordenou a prisão de Alberto Jorge de Mestre Cordero e de Fernando Francisco Malfussi, dois argentinos que viviam no Rio de Janeiro e que haviam passado o documento a Lacerda. Soube-se depois que ambos confessaram sua falsificação.

Nesse momento, muito provavelmente, parecia claro a Lacerda que o horizonte político dos próximos dias não lhe traria boas novas. A partir de então, ele delineou uma nova estratégia - a de chamar atenção para outros aspectos das relações entre Jango e o peronismo, que, em sua perspectiva, também mereceriam investigação. A iniciativa contou com apoio de outros udenistas. O deputado federal Rafael Corrêa de Oliveira (UDN-PB), por exemplo, solicitou ao responsável pelo inquérito que ouvisse jornalistas que vinham denunciando tal proximidade desde $1953 .^{707}$

À medida que passavam os dias, o resultado das urnas também foi ficando mais claro e confirmou os maus pressentimentos dos udenistas. Aparentemente, a divulgação da carta Brandi pouco efeito tivera sobre o eleitorado, que sufragou a fórmula J-J. Kubistchek foi eleito por uma estreita margem. Obteve $35,68 \%$ dos votos, sendo seguido por Juarez Távora (30,27\%), Ademar de Barros $(25,77 \%)$ e Plínio Salgado (8,28\%). Na vice-presidência, João Goulart atingiu 44,25\%, com uma vantagem de apenas 200 mil votos em relação ao udenista Milton Campos (41,70\%).

Previsivelmente, a eleição do governador de Minas Gerais com pouco mais de um terço dos votos válidos provocou protestos da oposição, que já alegara a necessidade da maioria absoluta dos votos em 1950, quando Vargas obteve "apenas" 48\% dos votos

\footnotetext{
706 "Peronismo, perigo imediato para o Brasil" In Tribuna da Imprensa, Rio de Janeiro, 17/10/1955 [edição final], p. 1.

707 "Maurell trabalhou a noite inteira e talvez fale hoje" In Tribuna da Imprensa, Rio de Janeiro, 17/10/1955, p. 1 [1 ${ }^{\mathrm{a}}$. edição].
} 
válidos. Insistia-se dessa vez que os candidatos do PSD e do PTB haviam sido eleitos pelos comunistas e em conluio com os peronistas. No editorial intitulado "Dar posse aos gregórios é trair o Brasil", Lacerda, incansável, atacou: "Estamos, agora, diante de um fato: a eleição de Kubitschek e Jango, isto é, a volta dos gregórios, com uma ideologia de tipo peronista e uma aliança, que custará muito caro ao Brasil, com o Partido Comunista". 708

Embora a ala legalista da UDN tenha novamente levado o caso à Justiça Eleitoral, a possibilidade de aceitação da tese da maioria absoluta pelos juízes parecia remota mesmo para seus correligionários. Com isso, os adeptos da "tese golpista" se fortaleceram. De acordo com Maria Victoria Benevides, essa ala contava com o apoio de setores mais radicais da Aeronáutica e da Marinha. ${ }^{709}$ Lacerda, em especial, criticou o que chamou de "legalismo palerma" $" 710$ e assegurou que naquele momento essa posição funcionava como "pretexto para entregar o Poder aos inimigos do Brasil". Ele bradou: "Isto que aí está não é democracia". 711

No dia 17 de outubro, Maurell inesperadamente adiantou o resultado de uma nova análise grafológica feita pelo perito criminal brasileiro Antônio Carlos Villanova, que teve acesso a um número bem maior de padrões de assinatura de Brandi, colhidos na Argentina. Chefe da Seção Química do gabinete de Exames Periciais do Departamento Federal de Segurança Pública (DFSP), Villlanova não teve dúvida: a assinatura da carta fora falsificada. ${ }^{712} \mathrm{O}$ inquérito, porém, continuaria.

A notícia foi péssima para Lacerda, que passou a ser duramente acusado pela imprensa próxima ao PTB, como o jornal Última Hora, de falsificador e falsário. Inicialmente, ele assegurou que o general estava enganado, criticou sua precipitação em apresentar informações de um inquérito não concluído e, entre outras objeções, lembrou que ele próprio ainda não havia sido ouvido no inquérito. Destacou novamente que eram "mais importantes os fatos relatados na carta do que o próprio documento cuja autenticidade não podia comprovar". Alegou, ainda: "Pode ser a carta falsa - e verdadeiros serem os fatos e circunstâncias que ela menciona, ou aqueles que tenham

\footnotetext{
${ }^{708}$ LACERDA, Carlos. "Dar posse aos gregórios é trair o Brasil” In Tribuna da Imprensa, Rio de Janeiro, 10/10/1955(edição final), p. 4.

${ }^{709}$ BENEVIDES, op. cit., p. 98.

${ }^{710}$ LACERDA, Carlos. "Apaziguamento e legalismo de Chambelain a Sobral Pinto" In Tribuna da Imprensa, 1/9/1955, p. 4.

${ }^{711}$ LACERDA, Carlos. “A hora das Forças Armadas". Tribuna da Imprensa, Rio de Janeiro, 4 de novembro de 1955 , p. 4.

712 "Prometeu em 10 dias; revelou em 72 horas" In Tribuna da Imprensa, Rio de Janeiro, 18/10/1955, p. 7.
} 
com eles correlação". ${ }^{713}$ Também insistiu em lembrar que diversos eventos de anos anteriores sobre a "infiltração peronista" no Brasil deveriam ser examinados, como os depoimentos de João Neves da Fontoura, Segadas Viana, Góes Monteiro, Ciro de Freitas Valle e outros. Nesse diapasão, Hugo Baldassari, advogado pessoal do jornalista, atribuiu aos petebistas a concentração do inquérito apenas na missiva:

[...] o poderio da propaganda dos aliados de Jango Goulart conseguiu deslocar a questão para a já famosa carta e as atividades peronistas do pretenso herdeiro político de Getúlio Vargas estão passando a um plano secundário. Essa manobra, em arte militar, tem o nome de manobra diversionista, contudo, tal diversão se transformou em batalha principal e, afinal, pode-se dizer - usando a linguagem militar - que o conflito foi localizado e isolado em torno da carta. ${ }^{714}$

Uma charge não assinada publicada em Tribuna da Imprensa fez coro à ideia de que a missiva falsa fora introduzida no circuito político para beneficiar João Goulart, livrando-o da acusação de conluio com o regime peronista. Na figura, o líder gaúcho utiliza um envelope de carta como escudo contra as acusações (figura 23).

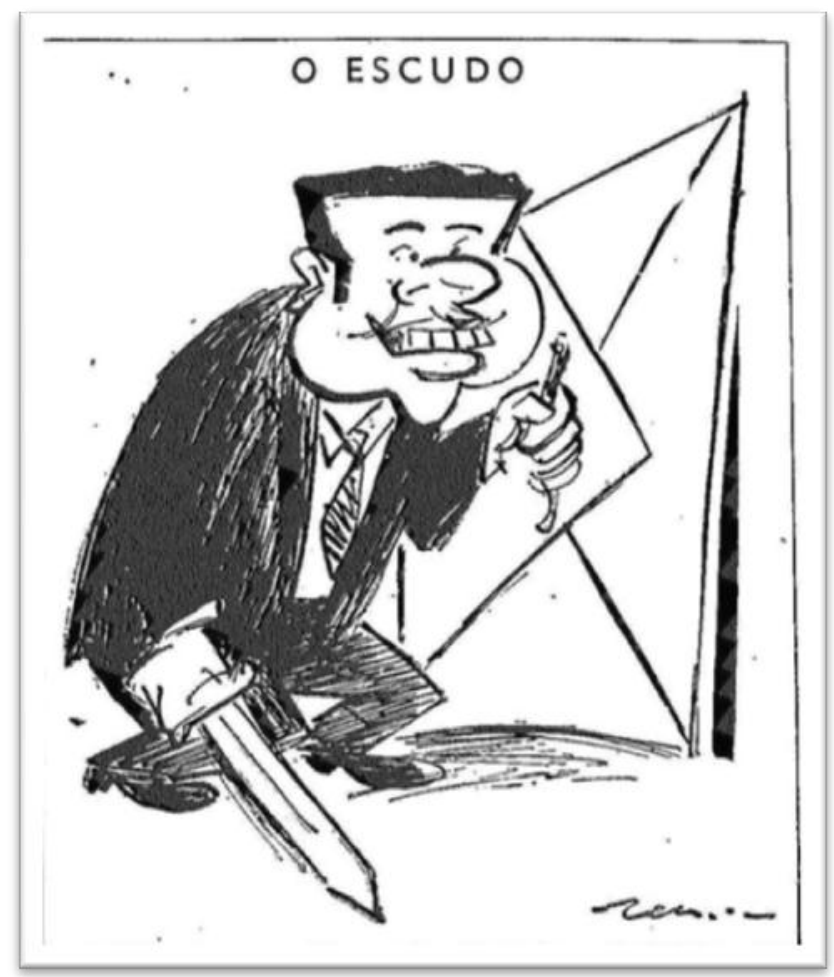

Figura 23 - Tribuna da Imprensa, 24/10/1955

\footnotetext{
${ }^{713}$ LACERDA, Carlos. “A carta é o ponto de partida e não ponto final” In Tribuna da Imprensa, Rio de Janeiro, 20/10/1955, p. 1 e 4.

714 BALDASSARI, Hugo."Equívocos do 'affaire' Jango" In Tribuna da Imprensa, Rio de Janeiro, 19/10/1955, p. 1 e 2.
} 
Após alguns dias de postergação, Lacerda prestou depoimento diante do general Maurell, em 27 de outubro de 1955. Levou consigo um calhamaço de 110 laudas datilografadas e 60 documentos. De acordo com a Tribuna da Imprensa, o acontecimento teria chamado atenção de cerca de quinhentas pessoas, que se aglomeraram à porta do quartel da Polícia do Exército, no bairro do Andaraí. ${ }^{715} \mathrm{O}$ prolixo testemunho, bem ao estilo de Lacerda, foi publicado no dia seguinte. Firme em relação à sua linha de raciocínio, ele titulou-o "A Traição em Marcha" e fustigou: "A verdade sim! Mas a verdade inteira!". 716

$\mathrm{Na}$ ocasião, Lacerda apresentou-se como vítima e alegou ter caído, junto com o coronel Adil de Oliveira, em uma "armadilha" que faria parte de "uma trama para glorificar João Goulart e procurar desmoralizá-lo, ao coronel Adil de Oliveira, à Força Aérea Brasileira e ao Clube da Lanterna". ${ }^{717}$ Conformado com a conclusão a respeito da falsidade da carta, ele eximiu-se de qualquer culpa: "Se o documento é falso, como se afigura, tenho a dizer que não o falsifiquei, não o mandei falsificar, não colaborei para sua falsificação". 718

A autovanglorização e a tentativa de retratar sua atuação política como um sacrifício para salvar a nação, tão frequentes em seus discursos, também estiveram presentes. Ele escreveu: "Assumi um risco calculado, sem heroísmo algum, pois me parecia muito remoto. Mas este foi, afinal, o mais certo. Cabe-me suportá-lo sozinho".

Lacerda narrou que tivera os primeiros contatos com os "meliantes" argentinos Fernando Malfussi e Alberto Mestre Cordero em junho de 1955. O primeiro foi-lhe apresentado por um colega jornalista e dizia ter provas do contrabando de armas na fronteira, assunto que vinha sendo insistentemente veiculado, especialmente na Tribuna da Imprensa. Em seguida, Malfussi teria lhe introduzido a Cordero, que se apresentou como um antiperonista exilado e proprietário de grande patrimônio que fora bloqueado pelo governo platino. Ele informou ser amigo de antiperonistas de destaque que possuíam reconhecidas ligações com Lacerda.

\footnotetext{
715 "Ameaçado de morte na presença de Jango" In Tribuna da Imprensa, Rio de Janeiro, 28/10/1955, p. 1 e 4.

${ }^{716}$ LACERDA, Carlos. “A Traição em Marcha” In Tribuna da Imprensa, Rio de Janeiro, 29-30/10/1955, 24 p. (Suplemento especial). (Acervo Carlos Lacerda - UNB).

717 "Ameaçado de morte na presença de Jango" In Tribuna da Imprensa, Rio de Janeiro, 28/10/1955, p. 1 e 4.

${ }^{718}$ LACERDA, Carlos. “A Traição em Marcha” In Tribuna da Imprensa, Rio de Janeiro, 29-30/10/1955, 24 p. (Suplemento especial), p. 3.
} 
Pouco depois, Cordero teria oferecido espontaneamente ao jornalista fluminense documentação que poderia "evitar a vitória do tipo brasileiro de peronismo". ${ }^{719}$ Ao contrário do esperado, não lhe falou em dinheiro em nenhum momento. Em contraste com sua versão inicial, Lacerda esclareceu no testemunho à justiça que a carta Brandi não fora apreendida por uma autoridade. Cordero the teria confessado que a roubara deliberadamente do argentino Ignacio Pinedo, o suposto portador da missiva, ao conhecê-lo em um hotel no Rio de Janeiro.

Assim que tomou contato com a carta Brandi, o jornalista estranhou diversas inconsistências, a começar pela coincidência na data de sua expedição, 5 de agosto, o mesmo dia do atentado da rua Tonelero. ${ }^{720}$ Todavia, o material lhe despertou muito interesse e um problema de consciência, que foi resumido por ele nas seguintes palavras: "O peronismo avança; eu tenho uma carta para barrá-lo". ${ }^{721}$

Antes de tornar pública a carta Brandi, Lacerda teria mostrado a alguns amigos e autoridades, entre elas João Adil de Oliveira, chefe da $2^{a}$ Seção do Estado Maior. Este lhe exigiu uma denúncia formal para investigar mais profundamente o caso, o que não foi feito, de acordo com Lacerda, por recomendação de Cordero, que temia contato com a polícia local. Ao contrário do que veiculou a Tribuna da Imprensa, que assegurou desde o início sua autenticidade, Lacerda teria reconhecido nessas conversas privadas iniciais "a possibilidade, embora remota, de ser falso o papel". 722

Em seu depoimento, o jornalista adotou a estratégia de repetir à exaustão a denúncia de um conluio entre trabalhistas e peronistas. Astutamente, Lacerda entremeou explicações sobre as circunstâncias do aparecimento da carta Brandi com longas acusações nesse sentido. Sem provas cabais dessa relação, baseou-se em algumas ilações e suposições feitas a partir de longas citações de documentos e testemunhos de dezenas de diplomatas, militares e outros homens públicos brasileiros. Esses indícios foram apresentados como provas insofismáveis e deram o fio condutor à ideia de uma traição silenciosa ao País.

\footnotetext{
719 Ibidem, p. 4.

${ }^{720}$ Curiosamente, Lacerda evocou repetidas vezes outro polêmico documento, a carta Testamento de Getúlio Vargas, que veio a público num momento definido por ele como "o golpe de 24 de agosto" [de 1954]. O jornalista lembrou que, embora decisiva nos destinos políticos do país, ela nunca fora objeto de um inquérito policial que averiguasse as circunstâncias de sua produção. Lacerda definiu-a ainda como um escrito "destinado à lançar o ódio e provocar a guerra civil no país, espécie de súmula diabólica das calúnias comunistas e peronistas contra as Forças Armadas e demais forças democráticas do Brasil”. Ibidem, p. 16.

${ }^{721}$ Ibidem, p. 12.

${ }^{722}$ Ibidem, p. 10.
} 
Dessa forma, manteve-se a estratégia de apontar a carta como ponto de partida para futuras investigações, e não o de chegada. Segundo ele: "A carta é falsa? Mas os crimes contra o Brasil existiram - e todos esses indícios os comprovam. Nada se vai fazer sobre eles? Não produzem consequências? Que é mais importante: a carta ou o crime?". ${ }^{723}$ Em outro trecho, ele acusou: "Sabendo que ela é falsa permanece o dado essencial: é falso que o sr. João Goulart seja peronista, tenha pactuado com o peronismo, e esteja, de braço dados com o comunismo, pronto a usar o Poder para peronizar o Brasil?", 724

Ao final, Lacerda acusou Cordero, principal responsável pela falsificação, de possuir ligações com Jango e com Vargas e de ter trabalhado como "provocador" a serviço do presidente argentino. Reafirmou sua posição de vítima e acusou o argentino preso de estar "a serviço de terceiros, empenhado na minha desmoralização e na glorificação de João Goulart", ${ }^{725}$ No último trecho, aduziu:

Falta agora a parte que mais interessa à Nação - e interessaria mesmo que fosse o último dos miseráveis, o mais infame dos falsários ou dos mandantes de falsidades:

QUAL A RESPONSABILIDADE DE JOÃO GOULART E SEU GRUPO NA INFILTRAÇÃO PERONISTA NO BRASIL, NA INTRIGA E NA CIZÂNIA ENTRE OS BRASILEIROS, NA SUBVERSÃO DA ORDEM EM CONLUIO COM UM REGIME E UMA FORÇA ESTRANGEIRA? Qual o vulto do contrabando de armas na fronteira e qual a sua destinação? Qual o alcance da penetração dos agentes peronistas, com GOULART e outros, no meio dos trabalhadores brasileiros?

Cometi o erro de acreditar que tinha em mãos um documento autêntico? É possível. Dado o merecido crédito à conclusão do general Maurell, é certo. Mas, se fui enganado, quem me enganou? Quem procurou enganar ao general Maurell?

Foram as mesmas pessoas. É o mesmo grupo. Tinham a mesma finalidade. ${ }^{726}$

$O$ Estado de S. Paulo, jornal paulistano de fortes ligações udenistas, saudou o longo depoimento de Lacerda como uma peça "capaz de ocasionar mudança radical no curso das investigações militares do inquérito". ${ }^{727}$ Não foi o que aconteceu. Na véspera do feriado de finados, Maurell tornou público o relatório final que concluía pela falsidade da carta Brandi. Contrariando os insistentes pedidos de Lacerda, a investigação centrou-se apenas na missiva e nos supostos eventos citados nela. Maurell tampouco recomendou novo inquérito para investigar as relações entre peronistas e

\footnotetext{
${ }^{723}$ Ibidem, p. 21.

${ }^{724}$ Ibidem, p. 10.

725 Ibidem, p. 19.

${ }^{726}$ Ibidem, p. 22.

727 “O depoimento de Lacerda modificará o inquérito" In Tribuna da Imprensa, Rio de Janeiro, 31 de outubro de 1955 , p. 1.
} 
trabalhistas. Questionado a respeito, redarguiu: “Coisas fora da época não me cabiam apurar", 728

Alberto Jorge Mestre Cordero e Fernando Francisco Malfussi, dois argentinos que faziam jogo duplo politicamente e viviam, nas palavras do relatório, em "precaríssima situação financeira", foram, após confissão, presos e formalmente indiciados. O primeiro já respondia a processo no Brasil por "crime de estelionato e defraudações várias" e o segundo foi classificado por Maurell como um notório "vadio contumaz e cínico vigarista". Para Maurell, não havia indícios ou provas da participação de terceiros na qualidade de mandantes do crime.

Assim, Lacerda não foi formalmente acusado de falsificação. O general que liderou a investigação disse estar convicto de que o jornalista fluminense e outras pessoas que haviam utilizado a carta para objetivos políticos tinham sido realmente ludibriados pelos dois argentinos. No entanto, o relatório indicou que a dupla de falsários teria se aproveitado da ânsia desses grupos políticos que buscavam avidamente documentos que comprovassem os boatos sobre relações escusas com o peronismo. Sem dar nome aos bois, Maurell criticou-os indiretamente por mau jornalismo, pois teriam apresentado provas "sem mesmo indagar as fontes de onde provinham e nem a idoneidade moral de quem as fornecia”. Explicava o relatório:

\begin{abstract}
Estimulados pela insistência e notória avidez com que certos grupos ligados à política partidária e a certos órgãos de imprensa, procuravam obter informes capazes de confirmar e, se possível, caracterizar os boatos, de há muito circulantes, sobre contrabando de armas na fronteira com a Argentina, além de outros relativos a apregoadas atividades de pessoas ligadas ao Governo Vargas junto a Perón e a seus adeptos - Cordero e Malfussi, cuja identidade de propósitos crescia dia a dia - resolveram tirar partido da situação que atingira o seu clímax nos últimos meses que antecederam os comícios eleitorais de 3 de outubro último. ${ }^{729}$
\end{abstract}

A partir de então, a avalanche de críticas e acusações contra Lacerda avolumouse ainda mais. Em sua defesa, o deputado federal Adauto Cardoso (UDN-DF), membro da "Banda de Música udenista", declarou que o episódio fora arquitetado intencionalmente com propósito de prejudicar o jornalista e “destruir, com o escândalo

\footnotetext{
728 "Maurell apurou apenas uma parte da verdade" In Tribuna da Imprensa, Rio de Janeiro, 1 de novembro de 1955, p. 1.

729 "Maurell sepulta o inquérito na véspera de finados" In Tribuna da Imprensa, Rio de Janeiro, 1 de novembro de 1955 , p. 3.
} 
de uma prova falsa, facilmente desmoralizável, fatos que, por outras vias e meios, desde muito se tinham tornado indiscutíveis". 730

O jornal paulistano sob direção da família Mesquita também apoiou firmemente o jornalista fluminense no caso da carta Brandi. Seguindo a linha da Tribuna da Imprensa, assegurou que "a autenticidade da carta pode ser discutida, mas o que não pode ser posto em dúvida é que o sr. Goulart e o ex-ditador viviam em contato e que esses contatos facilitaram a remessa de armas da Argentina para o Brasil". Em um editorial intitulado "Peronismo e getulismo", O Estado de S. Paulo fustigou violentamente o político gaúcho:

Não há como negar a existência de ameaças sérias à nossa vida política em consequência dos entendimentos entre o sr. Goulart e o presidente argentino. $\mathrm{O}$ inquérito que se iniciou a propósito da carta deve prosseguir. Se as Forças Armadas se acham de posse, como se assegura, de informações sobre as atividades antipatrióticas do ex-ministro do Trabalho do ditador brasileiro, corre-lhes o dever de realizar rigorosa investigação a respeito desses fatos e, uma vez verificados, promover o processo criminal contra esse político, de frouxo patriotismo mas de ambições alentadas a fim de que receba o devido castigo. Atos de traição não podem ficar impunes. Quando entram em jogo a vida de instituições e a própria independência do País a repressão contra os culpados deve ser implacável.

A ação contra esse político aliado do peronismo ditatorial deve ser levada a efeito imediatamente para que nos libertemos do perigo que seria a sua presença no Senado brasileiro como vice-presidente da República. Já temos sofrido muito com a mediocridade e a imoralidade de certos políticos. Não é possível que venhamos a sofrer também com a falta de patriotismo de outros. Se a ambição do ex-ministro do Trabalho é de tal porte que para satisfazê-la ele não recua diante da traição à Pátria, também não devemos recuar diante do que for indispensável para ele seja rigorosamente castigado. ${ }^{731}$

O Cruzeiro adotou uma postura bem mais comedida. Em sua coluna Política, perguntou: “Os erros de Lacerda prejudicam o golpe?”. O artigo deixava clara a enorme influência do jornalista e deputado federal naquela grave crise política após as eleições, definida pelo magazine como o "processo revolucionário de que [Lacerda] se tornou um foco agressivo e o polo mais visível”. O texto aduziu:

\begin{abstract}
Não resta dúvida de que seus artigos e discursos constituem a expressão audaciosa e exasperada de um estado de espírito que, muitas vezes, se arreceia do apelo à violência e à força, mas que, nas suas diversas modulações, se identifica no mesmo anseio de impedir a entrega do poder ao grupo Kubitschek-Jango, em cuja vitória denuncia a ressurreição do regime deposto em 24 de agosto.
\end{abstract}

\footnotetext{
730 "O documento Brandi foi forjado contra Lacerda" In Tribuna da Imprensa, Rio de Janeiro, 1 de novembro de 1955 , p. 3.

731 “Peronismo e getulismo" In Tribuna da Imprensa, Rio de Janeiro, 3 de novembro de 1955, p. 3.
} 
No entanto, a revista ilustrada de Assis Chateaubriand criticou duramente sua atuação no episódio da carta falsificada, definido este como "uma nova batalha perdida nessa guerra do udenismo contra o getulismo, da direita contra a esquerda". A coluna assegurou que o líder conservador agira:

[...] com certa facilidade ao se deixar envolver até a intimidade por agentes escusos e misteriosos e submeteu-se com precipitação a uma prova pública das mais difíceis, qual seja a de procurar, com a boca no mundo, comprovar denúncias na base de um documento de cuja autenticidade ele mesmo duvidava. $^{732}$

Semelhante postura adotou $O$ Globo, diário vespertino de Roberto Marinho, que com frequência abria as portas de sua rádio a Lacerda, inclusive no dia das eleições. $\mathrm{O}$ jornal disse estar convencido da inexistência de qualquer "intenção dolosa de nosso colega". Além disso, exaltou seu "espírito de sacrifício", sua "repulsa à corrupção" e criticou a "agressiva e injusta" campanha que se desencadeava sobre ele naquele momento por parte da imprensa e do Congresso. Todavia, censurou seus "excessos de temperamento" e creditou que esses o haviam levado, em algumas ocasiões, a "cometer graves erros de apreciação quanto a pessoas e fatos". 733

Coincidentemente, no mesmo dia em que Maurell anunciou suas conclusões, um fato inesperado ampliou a crise política pós-eleições. No enterro do general Canrobert Pereira da Costa, que fora um dos principais líderes da pressão exercida sobre Vargas na crise de agosto de 1954, o coronel Jurandir Mamede, também antigetulista, elogiou o colega falecido e criticou abertamente a posse de Juscelino e Jango. Sob chuva torrencial, alegou que eles representavam a "vitória da minoria" e que sua posse confirmaria uma "indiscutível mentira democrática". Ao final da cerimônia, Mamede foi cumprimentado efusivamente por diversos líderes militares e civis, entre eles, Carlos Luz, um político de ligações com a ala golpista do udenismo que ocupava o cargo de presidente da Câmara dos Deputados. ${ }^{734}$

Um dos presentes na ocasião, o ministro da Guerra, Henrique Lott, entendeu o pronunciamento como um claro ato de insubordinação. Legalista, Lott defendia o respeito à Constituição e a posse dos eleitos. Ele vinha atuando também no sentido de impedir qualquer pronunciamento político por parte de membros mais exaltados do Exército nos dois polos da pugna política.

\footnotetext{
732 “Os erros de Lacerda prejudicam o golpe?” In O Cruzeiro, Rio de Janeiro, 12/11/1955.

${ }^{733}$ Apud DULLES, op. cit., p. 219

${ }^{734}$ CARLONI, op. cit., p. 131
} 
O discurso de Mamede coadunava-se claramente com pregação golpista que seduzia principalmente setores militares e vinha sendo tenazmente difundida por alguns políticos udenistas e jornais como Tribuna da Imprensa e O Estado de S. Paulo. ${ }^{735} \mathrm{O}$ matutino paulistano, por exemplo, enalteceu em editorial os militares argentinos que haviam tomado recentemente o poder e banido o partido justicialista. No texto, republicado pela Tribuna da Imprensa, a hesitação e a negligência da caserna brasileira em interferir em momentos-chave, como o fim do Estado Novo e a crise que levou ao suicídio de Vargas, foram duramente criticadas:

O QUE o governo provisório da Argentina acaba de fazer em relação ao partido peronista, maior destaque dá ainda ao erro duas vezes perpetrado no Brasil. Ao contrário do que sucedeu entre nós, o movimento revolucionário em que se empenharam as Forças Armadas da República do Prata não se deteve em meio caminho e decidiu levar até ao fim a reforma política que as correntes democráticas reclamavam. Se erros e traições futuramente houver, não os poderá o povo argentino atribuir à negligência dos militares e marinheiros em limparem o terreno dos últimos remanescentes da ditadura demolida. O que dela politicamente restava, e que viria a ser fermento de novas agitações e tentativas de novo assalta ao poder, acaba o governo do presidente Lonardi de o varrer da arena política argentina assinando o decreto de dissolução do partido peronista.

Só deste modo, com efeito, se compreende e inteiramente justifica a interferência das Forças Armadas de um país na vida política nacional. Se essa interferência se dá porque, privado o povo de poderes jurídicos e legais para se defender e impor a sua vontade a uma minoria audaciosa que se apoderou do poder e de todos os instrumentos da lei, só as Forças Armadas têm o poder de restabelecer a legalidade e a ordem, não se concebe que ela não seja levada às suas últimas consequências. A destituição de um homem não altera um regime, do mesmo modo que a mudança do rótulo não altera o conteúdo de um frasco. Ora, aquilo que no Brasil se assistiu, quer em outubro de 1945, quer em 1954, foi precisamente a mudança, de rótulo e conservação de conteúdo. Havermos de convir que, para tanto, não seria indispensável a rijeza de um sabre...

Alegando que os petebistas haviam obtido ilegalmente o apoio dos comunistas, o jornal paulistano conclamou os oficiais locais a agirem para terminar "o que têm tido escrúpulo em acabar":

\footnotetext{
${ }^{735}$ A respeito de $O$ Estado de S. Paulo nesse período, Maria Victoria de Mesquita Benevides comentou: "O Estado de S. Paulo, além da tradição antigetulista, expressava aquilo que poderia significar o "liberalismo restrito" dos bacharéis paulistas. Os editoriais refletiam, com aguda frequência, algumas posições constantes na retórica udenista: a denúncia da "irresistível tendência das massas para o "pulha", no exemplo extremado de Plínio Barreto; a defesa dos proprietários rurais, especialmente os cafeicultores (a denúncia do confisco cambial); a condenação da "hegemonia" estatal na economia; a defesa da intervenção "salvadora" das Forças Armadas, e aí, a conjugação com as teses lacerdistas e golpistas dos "estados de exceção"; e a ambígua representação das aspirações das "classes médias", na mitificação dos temores de "proletarização"” (BENEVIDES, op. cit., p. 237).
} 
Nós aguardamos ainda, para nos pronunciarmos então, que as Forças Armadas terminem o que têm tido escrúpulo em acabar. Não é a violência que pedimos. Queremos tão somente, que se leve até as últimas consequências esse respeito à legalidade. Somos, como o ministro da Guerra, intransigentemente, obstinadamente, pelo respeito à lei. Que ela se cumpra. Mas que ela se cumpra em toda a sua integridade. ${ }^{736}$

Nesse sentido, mas em tom bem mais exaltado, a Cruzada Brasileira AntiComunista veiculou naqueles dias um comunicado em que também criticou violentamente a associação entre João Goulart e os comunistas, alegando, entre outras coisas, que "esse indivíduo agitador" contribuíra financeiramente com o partido que estava na ilegalidade. Inconformada com o resultado do pleito, a entidade comentou: "Cerca de três milhões de eleitores inconscientes, mistificados pela canalha comunogetulista, votaram em Jango Goulart - a esperança no. 1 do Kominform no que respeita a bolchevização do Brasil - para vice-presidente da República”.

É bastante interessante nesse documento certo entrelaçamento entre o anticomunismo e o antiperonismo. O texto denuncia os contatos frequentes de Jango com pessoas ligadas à embaixada Argentina e argumenta que ele havia sido deposto do cargo de ministro do Trabalho "devido ao seu trabalho desagregador e a querer dividir a Nação, entregando-a de pés e mãos amarrados a Perón e a sua camarilha". Ao final, emendou: "Jango como ministro não servia, pois trabalhava contra o Brasil, como vicepresidente da República, servirá? Que me respondam os militares brasileiros, que depuseram Vargas e sua camarilha!!!" ${ }^{737}$ Como se pode observar, tratava-se, no fundo, da mesma representação difundida há anos - a de Jango como traidor, em conluio com a União Soviética e com Argentina.

No entanto, nem todos os veículos de comunicação liberais-conservadores clamaram pelo golpe. ${ }^{738}$ O Correio da Manhã, por exemplo, defendeu incisivamente a posse dos eleitos e bateu pesadamente naquele que havia sido um dos seus principais colunistas na década de 1940: "tudo em Carlos Lacerda é pequeno, mesquinho, desprezível [....] De real nele, só a vaidade que atinge a paranoia e uma crueldade que vai até a fúria assassina. O seu ideal seria a provocação de suicídios semestrais". ${ }^{739}$

Do mesmo modo, o apelo aos militares não seduziu a todos os udenistas. Ao contrário de Lacerda, uma parte significativa do partido iniciou uma batalha jurídica

\footnotetext{
736 “Que a lei se cumpra!” In Tribuna da Imprensa, Rio de Janeiro, 27/10/1955, p. 4.

737 "Jango: contribuinte do Partido Comunista” In Tribuna da Imprensa, Rio de Janeiro, 31 de outubro de 1955 , p. 2.

${ }^{738}$ A respeito, ver CARLONI, op. cit., p. 126.

${ }^{739}$ DULLES, op. cit., p. 223.
} 
contra a posse de Kubistchek, sob alegação de fraude eleitoral em diversos pontos do País. ${ }^{740}$ Importantes líderes, como Afonso Arinos, também se posicionaram contra soluções que violassem a Constituição. ${ }^{741}$ Ironicamente, o próprio general Juarez Távora, candidato derrotado por Kubistchek, não aderiu ao coro pela intervenção militar.

De volta à crise, o violento discurso do coronel Jurandir Mamede contra a posse dos eleitos acirrou ainda mais os ânimos. Rapidamente, o ministro da Guerra, Henrique Lott, solicitou ao presidente da República a punição de Mamede. Ao relembrar o episódio, o general justificou: "o cel. Mamede estava como uma criança mimada, agarrada às saias da avó, a fazer caretas para o pai... Com isso, sofria danos irreparáveis o elo básico do Exército, que era a disciplina", ${ }^{742}$

Lacerda, cada dia mais ousado, entendeu aquele instante como um momento crucial e veiculou um editorial conclamando os militares a agirem e executarem imediatamente a "revolução" para impedir a posse "desses dois aventureiros irresponsáveis". Em "A hora das Forças Armadas", alegou que o Brasil não tinha uma democracia de verdade, mas um sistema ilegal, em "adiantado sistema de decomposição" e no qual grande parte da "massa getulista" já estaria sob controle do Partido Comunista. Eis um trecho do texto:

\footnotetext{
Agora, já é tarde demais para hesitação. O dilema é este: ou se estabelece o regime de emergência ou tomam posse Kubitschek e Jango para imporem ao país, em pouco tempo, uma ditadura e, como inevitável consequência, uma guerra civil - pois neste país há milhões de pessoas que não se conformarão em voltar ao jugo dessa camorra que há mais de 20 anos explora e degrada a República. [...]

A posse desses dois aventureiros irresponsáveis só poderá ser evitada por um ato de força. Nesse mesmo ato se contém a instauração de um regime cuja legalidade tem de ser por ele próprio criada.

Este é o ponto que precisa ficar bem claro. A hora é de ação. E a ação, neste passo, não somente compete como depende das Forças Armadas. [...]

O domínio de uma Oligarquia não se extingue por manobras de mera e duvidosa habilidade. Só por um ato de força pode mudar o curso de acontecimentos que se entrosam num sistema criado por outro ato de força. A réplica de 1937 está por ser dada, não como uma desforra, mas como uma complementação de 45 e de 54, que ficaram interrompidas em meio, revoluções engasgadas, que não seguiram o seu curso e não foram capazes, sequer, de impedir a volta da camorra ao Poder.
}

\footnotetext{
${ }^{740}$ Ibidem, p. 227.

${ }^{741}$ Ibidem, p. 225.

${ }^{742}$ Apud Carloni, op. cit., p. 135.
} 
Esta é a hora em que os chefes das Forças Armadas, responsáveis pela defesa do Brasil contra os seus inimigos externos e internos, tem de assumir, perante a História, a sua quota indeclinável de responsabilidades [...]. ${ }^{743}$

No dia seguinte ao discurso de Mamede, porém, o presidente Café Filho teve um ataque cardíaco e foi substituído temporariamente pelo presidente da Câmara dos Deputados, Carlos Luz, político de notórias relações com os golpistas. Dias depois, este informou a Lott que não puniria Mamede pelo discurso. A atitude culminou na renúncia do ministro da Guerra em protesto. A partir daí, os acontecimentos de aceleraram. Na madrugada de 11 de novembro, Lott, desconfiado de uma conspiração envolvendo parte da oposição civil e militar, mobilizou tropas e ocupou pontos-chave da capital federal.

Luz, Lacerda, Mamede, alguns ministros e oficiais embarcaram rapidamente no cruzador Tamandaré e partiram, sob tiros, em direção a Santos com a perspectiva, que se mostrou frustrada, de organizar a resistência. Em seguida, a Câmara dos Deputados votou o "impedimento" de Luz e empossou Nereu Ramos, vice-presidente do Senado, como novo presidente interino. Logo depois, o Congresso, com grande número de votos do PTB e PSD, aprovou o afastamento de Café Filho e declarou estado de sítio por trinta dias, condição prorrogada até a posse dos eleitos, que efetivamente ocorreu no final de janeiro de 1956.

Com a intervenção militar, o prédio da Tribuna da Imprensa foi tomado por tropas e o diário não circulou por dois dias. Lacerda asilou-se na embaixada de Cuba, governada então pelo ditador Fulgêncio Batista. Durante um ano de exílio, passou por Cuba, Estados Unidos e Portugal. A partir desses países, continuou sua produção jornalística atuando como correspondente do seu próprio diário. Coincidentemente, outro exilado, de ideias políticas bem distintas, também encontrou refugio em um país da América Central naquele mesmo mês. Temendo pela sua segurança em solo paraguaio, Juan Domingo Perón mudou-se para o Panamá. Nas escalas que seu voo fez no Brasil, relutou em sair do avião.

Oito meses após a conclusão do inquérito de Maurell, o juiz Pedro Ribeiro de Lima, da 9a. Vara Criminal do Rio de Janeiro, condenou Alberto Jorge Mestre Cordero e Fernando Francisco Malfussi, respectivamente, a três e dois anos e dois meses de reclusão pelo crime de falsificação da carta Brandi. Ambos também receberam multas. Na sentença, o magistrado considerou que Lacerda havia agido dolosamente ao publicar

\footnotetext{
743 LACERDA, Carlos. "A hora das Forças Armadas" In Tribuna da Imprensa, Rio de Janeiro, 4 de novembro de 1955 , p. 4.
} 
um documento a respeito do qual tinha confessadamente dúvidas em torno de sua autenticidade. Ao agir dessa forma, teria assumido "o risco da produção do resultado". ${ }^{74}$ De acordo com notícia da época, o juiz iria solicitar à Câmara dos Deputados permissão para indiciar o jornalista, que continuava em Portugal, licenciado das atividades parlamentares. ${ }^{745}$

Em um depoimento concedido um mês antes de sua morte, em 1977, o próprio Lacerda recordou o episódio da carta Brandi e definiu 1955 como o pior ano de sua vida. ${ }^{746}$ Eis algumas de suas impressões vinte e dois anos depois:

\begin{abstract}
Em suma, foi um revés, um desastre para mim, um negócio! Verdadeiramente talvez um dos períodos mais terríveis da minha vida, quer dizer eu passar como cúmplice de um falsário. E foi horrível! Não tenho a menor ideia da intenção desse argentino [Fernando Malfussi]. Dinheiro não era. Nunca me falou em dinheiro. Esperei inclusive que ele falasse. Nunca falou em dinheiro. E assim como apareceu, sumiu. Nunca mais vi esse sujeito. $^{747}$
\end{abstract}

Para Lacerda, a revelação da falsidade da carta Brandi não apenas o desmoralizou, mas sobretudo desacreditou o tema. Nos anos seguinte, enquanto as representações anticomunistas se fortaleciam no imaginário político, o antiperonismo aparentemente perdeu espaço. Como mostraram inúmeros estudos, em 1964, às vésperas do golpe militar, a principal acusação a recair sobre os ombros de João Goulart não era a de ser peronista, mas a de se aliar aos comunistas e de abrir as portas do País ao perigo vermelho.

Obviamente, também colaborou para esse enfraquecimento do imaginário antiperonista a própria queda do regime justicialista em outubro de 1955. Ela foi saudada efusivamente pelos meios de comunicação liberais-conservadores brasileiros. $\mathrm{Na}$ cobertura dos acontecimentos, a grande violência do novo governo contra os militantes peronistas dividiu espaço com inúmeras denúncias de que Perón acumulara enorme fortuna e de que mantivera casos amorosos com garotas secundaristas. Corrupto e imoral foram as principais representações que passaram a ser difundidas sobre o líder argentino no final do ano de 1955.

A expectativa pela queda do líder platino durou meses. Em 16 de junho daquele ano, edifícios do centro de Buenos Aires foram intensamente bombardeados numa

\footnotetext{
744 "Condenados Cordero e Malfussi" In A Noite, Rio de Janeiro, 21/7/1956, p. 10.

745 "Concluiu o juiz ter agido o deputado "dolosamente" no caso da Carta Brandi" In Diário de Notícias, Rio de Janeiro, 21/7/1956, p. 3.

${ }^{746}$ DULLES, op. cit, p. 3.

${ }^{747}$ LACERDA, 1978, op. cit., p. 106.
} 
tentativa frustrada dos militares de assassinar o presidente. Houve centenas de mortos e feridos. Perón escapou por muito pouco, mas o "Bombardeio da Praça de Maio" ampliou ainda mais a polarização ideológica daqueles dias.

No dia posterior a esses violentos ataques aéreos, Hilde assinou uma caricatura em que o rosto de Perón aparece riscado por uma cruz (figura 24). Acima, há a expressão hebraica "Mane, Thecel, Phares" [sic], uma referência ao Velho Testamento que significa "pesado, contado, dividido". De acordo com o livro de Daniel, essas palavras premonitórias teriam sido escritas por uma misteriosa mão nas paredes do local em que Belsazar, último rei da Babilônia, realizava sua última orgia. O significado delas é que algo inevitável e desastroso está na iminência de acontecer. Na narrativa bíblica, após a revelação, o imperador persa Ciro teria invadido a capital e matado Belsazar naquela mesma noite.

Trata-se de uma charge curiosíssima que indiretamente atribui ao próprio Perón a razão para sua queda e quase morte. Na visão da artista, seu governo imoral estaria fadado ao fim, tal qual o reino de Belsazar.

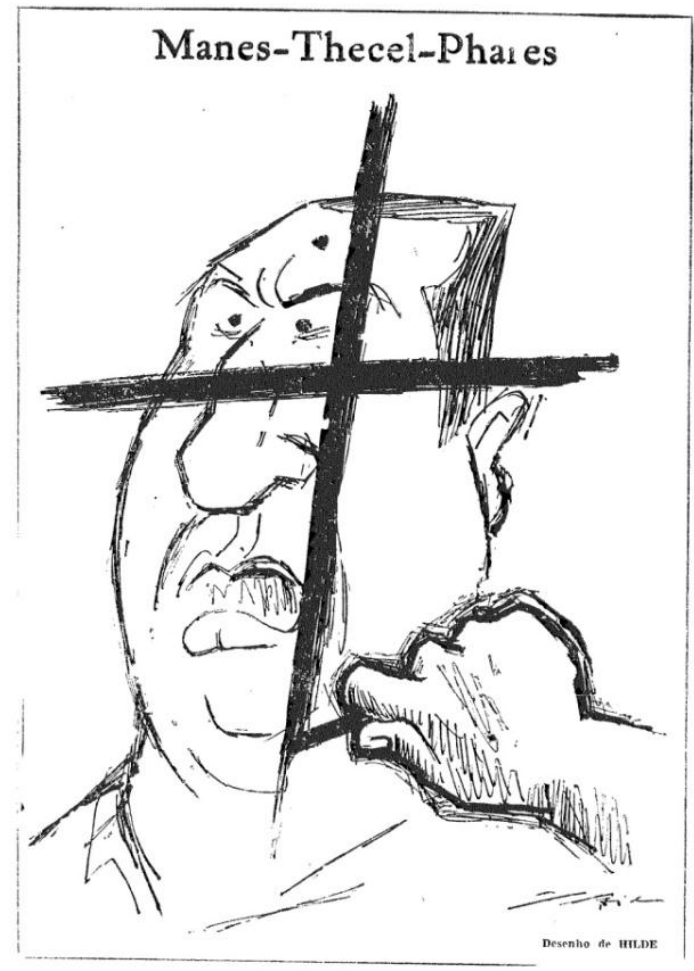

Figura 24 - HILDE. Tribuna da Imprensa, 17/6/1955, p. 4.

Uma charge mais cômica, mas com sentido semelhante, foi veiculada naquele mesmo mês (figura 25). Nela, Perón aparece sentado sobre uma bomba que prepara para 
acender. A legenda informa o resultado inevitável da traquinagem: "Custa, mais vai" (sic). A imagem remete à ideia de que o governante, na busca por um artifício esperto, acabava por desempenhar papel de tolo. Suas medidas políticas, tomadas supostamente para fortalecer o governo, estariam enfraquecendo-o ainda mais e preparando seu inescapável final. Possivelmente, trata-se também de uma crítica ao autoritarismo de Perón que, mesmo tendo concentrado enorme poder em suas mãos, contava com tenaz resistência de uma parte da sociedade argentina que se fortalecia cada vez mais a cada novo ataque.

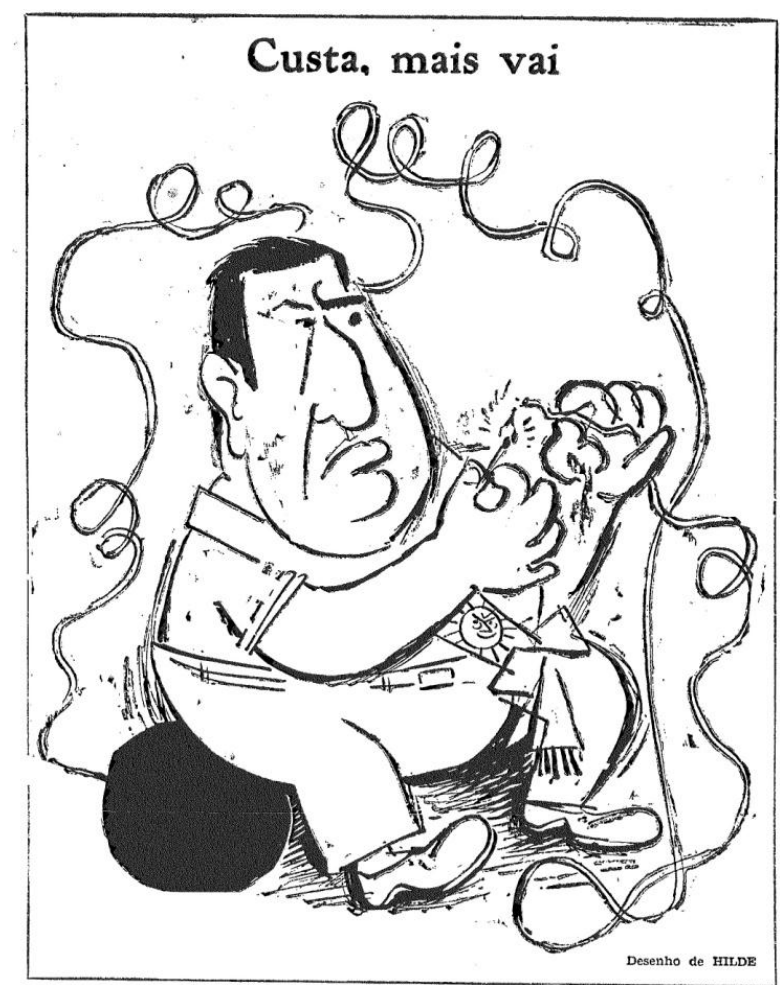

Figura 25 - HILDE. Tribuna da Imprensa, 18-19/6/1955, p. 4

Após a queda do justicialismo através de um golpe militar em setembro, Tribuna da Imprensa comemorou previsivelmente o ocorrido. Na charge de Hilde Weber (figura 26), a estátua de Perón sobre a insígnia da CGT aparece despedaçada. O tom de celebração é confirmado pela legenda: "Até que enfim".

A "Revolução Libertadora", liderada pelo general argentino Eduardo Lonardi, deu início a uma ineficaz política de "desperonização" da Argentina. Além da prisão de centenas de líderes, o partido peronista foi proscrito, assim como a utilização de símbolos e outras formas de menção ao líder deposto. Exilado em diversos países, a maioria ditatoriais, Perón ficou dezoito anos fora do poder. O justicialismo só ressurgiu 
oficialmente em 1973, quando o país retomou o caminho democrático. Após um curto período, ocorreram eleições, e Perón saiu-se vencedor. Com ironia, ele comentou que havia sido derrubado quando tinha todos os meios de comunicação a seu favor (1955) e triunfara quando todos eram contrários a ele (1973). ${ }^{748}$

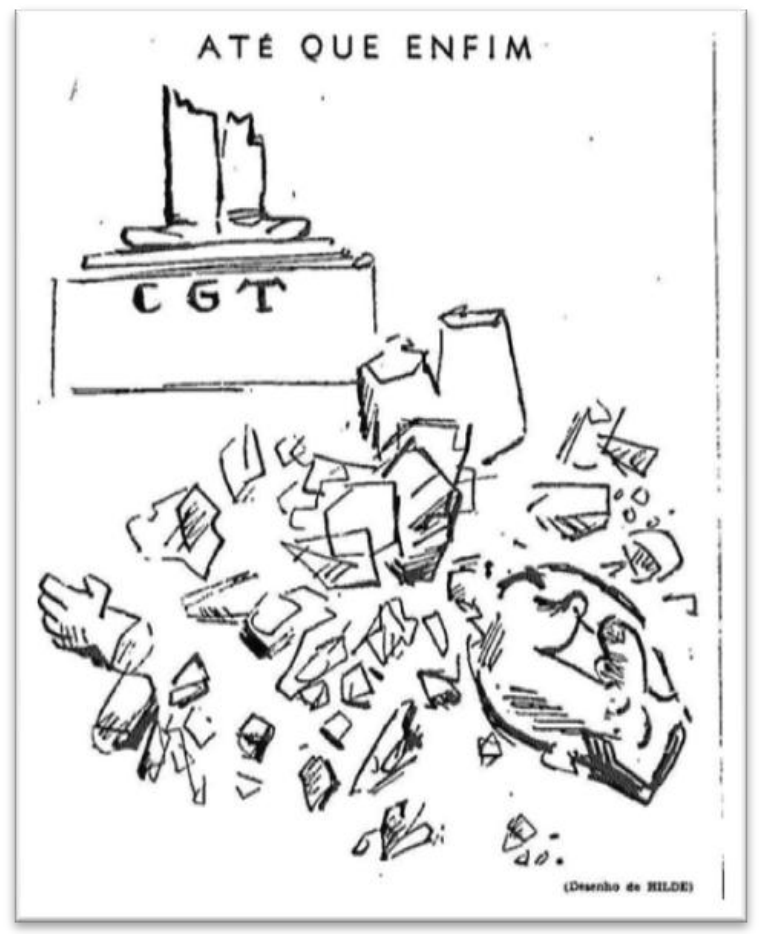

Figura 26 - HILDE. Tribuna da Imprensa, 20/09/1955, p. 4

Ao noticiar a queda, Tribuna da Imprensa publicou uma curiosa manchete com título: "A Argentina reintegra-se na democracia e no cristianismo". Entre outras coisas, noticiava-se a ocorrência de uma festa em um local bastante significativo:

Reunidos ontem na redação de "O Estado de S. Paulo", elementos da coletividade argentina aqui radicados, celebraram em intensa vibração, o fim da ditadura peronista.

Desde a tarde, tais elementos, entre os quais oficiais das Forças Armadas, participantes do movimento de 16 de junho, e que se encontram refugiados nesta capital - postaram-se junto ao teletipo da United Press instalado na redação do jornal.

Foi grande o júbilo dos democratas argentinos, quando o teletipo confirmou as notícias referentes à renúncia de Perón [...]

Logo após, no Salão Nobre do "O Estado", o sr. Júlio de Mesquita Filho ofereceu aos presentes uma taça de champanha, redundando a festa em verdadeira confraternização democrática. ${ }^{749}$

${ }^{748}$ CAPELATO, 2008, op. cit., p. 321.

749 “A Argentina reintegra-se na democracia e no cristianismo" In Tribuna da Imprensa, Rio de Janeiro, 20/9/1955, p. 2. 


\section{CONCLUSÕES}

Brasil e Argentina não firmaram acordos econômicos e políticos significativos no período estudado. A política externa de Dutra esteve alinhada ao pan-americanismo defendido pelos norte-americanos. Malgrado diversas iniciativas do lado platino, Getúlio Vargas e Juan Domingo Perón, considerados hoje exemplos expressivos do populismo latino-americano, sequer chegaram a se conhecer pessoalmente.

Contribuíram para esse desencontro entre os dois países muitos fatores. Podem ser apontados, entre outros, a postura refratária dos sucessivos chanceleres brasileiros, a intensa e polêmica campanha peronista de divulgação de sua ideologia nas nações vizinhas e a atuação da diplomacia e das agências de notícias norte-americanas que buscaram de, modo geral, obstruir as iniciativas de integração regional do governo platino.

Além disso, é motivo de controvérsia entre historiadores brasileiros a hesitação de Getúlio Vargas em efetivar a aproximação com o justicialismo. Para alguns, os afagos retóricos do político brasileiro ao chefe da casa Rosada não passaram de encenações calculadas para enciumar a diplomacia norte-americana com a possibilidade de acordos regionais. Nessa perspectiva, a Argentina nunca teria sido colocada como prioridade da política externa do País. Em contrapartida, outros pesquisadores acadêmicos têm apontado as enormes dificuldades políticas do líder gaúcho em ensaiar qualquer acercamento com o regime platino, já que contava com ampla e acirrada oposição interna.

Sem desconsiderar essas importantes discussões, esta tese procurou demostrar que a imprensa liberal-conservadora do Brasil também teve papel significativo nesse processo. Amplamente majoritária em termos de leitores, ela dificultou, através de sua atuação, a formação de condições políticas para a aproximação diplomática. Mais do que informar o que ocorria no país vizinho, os meios de comunicação analisados aqui fizeram uma deliberada campanha contra a experiência política justicialista.

Em tais periódicos, as críticas ao peronismo estiveram vinculadas principalmente à defesa dos direitos individuais, em especial da liberdade de expressão. Muitos dos jornalistas atuantes naquele momento haviam sido censurados anos antes pelos órgãos de controle do Estado Novo. Assim, inúmeras reportagens, editoriais e 
charges foram veiculados para denunciar o crescente autoritarismo do justicialismo. Sob tal prisma, esses meios de comunicação se colocavam como paladinos do liberalismo.

Ao mesmo tempo, a análise das fontes mostrou uma profunda rejeição à participação popular mais ampla e à extensão dos direitos sociais. Insistentemente, as medidas trabalhistas do governo argentino foram descritas como mera demagogia, o que mostra a postura conservadora desses meios de comunicação.

Resulta desses aspectos a definição, aparentemente contraditória, de uma imprensa liberal-conservadora. Nela, a defesa apaixonada da democracia e da liberdade de expressão convivia ambiguamente com uma forte rejeição às escolhas e demandas dos setores desfavorecidos da sociedade. Ignorava-se, por exemplo, que, ao menos em 1946, Perón fora eleito democraticamente.

Em consonância com essa perspectiva, os apoiadores do justicialismo foram reiteradamente classificados como uma "massa fanática e bárbara", que agia sob impulsos primitivos e era seduzida por uma forte propaganda. Para esses meios de comunicação, caberia aos "grupos mais esclarecidos" lutar pelo resgate da democracia e dos valores da civilização que teria sido subvertidos.

Esse representação de uma massa irracional, sem personalidade, guiada pelos seus instintos animais e seduzida por um líder imoral não era novidade no discurso dos conservadores latino-americanos. No caso analisado, ela produzia ao menos dois efeitos. Primeiro, tirava dos que a compunham, principalmente trabalhadores, a qualidade de agentes das transformações que estavam ocorrendo. Ao retratar o justicialismo como resultado da manipulação do povo eclipsava-se que, malgrado sua propaganda bastante intensa e inspirada no fascismo, o peronismo foi um movimento social apoiado por parte considerável da Argentina, país que possuía grau de alfabetização bem mais elevado do que o Brasil. Em segundo lugar, ficava subjacente a negação da luta de classes, pois Perón não representaria os interesses dos menos favorecidos, apenas os seus.

Nessa linha de raciocínio, a população argentina foi, grosso modo, poupada de críticas, pois não era destacada como agente político, mas como vítima de um grande mal, que, inspirado na experiência nazista, impunha o silêncio absoluto a todos. Inúmeras representações do período convergiram para Perón como encarnação desse mal absoluto. Tratava-se de um viés bastante maniqueísta que buscava personificar em um único indivíduo a responsabilidade por toda uma complexa gama de mudanças coletivas que vinham ocorrendo. 
Aliada à ideia de que o peronismo era um regime semelhante ao nazismo, difundiu-se a noção de que estavam sendo preparadas guerras para expandir seu domínio. Sob tal ótica, a política externa beligerante argentina seria consequência de uma política interna totalitária. Assim, as propostas de integração não passariam de armadilhas e o Brasil deveria se preparar para enfrentar a ânsia expansionista do presidente platino que representaria a revivescência de Juan Manuel de Rosas.

Principalmente após a eleição de Getúlio Vargas em 1950, o regime platino passou a ser descrito como mais do que um modelo político a ser rejeitado. Inúmeras representações davam conta de que ele significava uma verdadeira ameaça à democracia brasileira. A partir de notícias desencontradas, difundiu-se a noção de que, por meio de doações a campanhas eleitorais, treinamento militar e apoio armado, os peronistas estariam dispostos a ajudar os trabalhistas a criar no Brasil um regime semelhante ao justicialismo. A expressão "república sindicalista" foi difundida pela oposição para imputar aos partidários do PTB tal projeto autoritário. Ela traduzia a ideia de um governo de fachada democrática, com partidos fracos e baseado fortemente nos sindicatos.

Nesse momento, o antiperonismo difundido pelos meios de comunicação não visava apenas afastar o Brasil diplomaticamente da Argentina e garantir a continuidade do alinhamento aos Estados Unidos. Mais do que a preocupação com a política externa, interessava aos grupos que difundiram tais imagens atuar na política interna, fustigando Vargas e seus aliados ao atribuir a eles conjuras para estabelecer um novo regime discricionário no País.

A documentação levantada em diversas pesquisas historiográficas não permite concluir que era real o perigo de um golpe dos trabalhistas ao estilo peronista e com ajuda do governo de Buenos Aires. Não há provas nesse sentido. O que se pode assegurar é que as relações com o justicialismo configuraram um rico filão para a oposição brasileira, que difundiu enfaticamente esse "mito da conspiração". Nessa perspectiva, aspectos concretos, como o polêmico discurso de Perón na Escola Superior de Guerra em 1953, foram propositalmente mesclados a suposições e especulações de modo a compor uma narrativa minimamente coerente e convincente.

Do ponto de vista de udenistas como Carlos Lacerda, a existência de um inimigo que agia nas sombras (os trabalhistas) legitimava que a mesma estratégia fosse colocada em prática por eles, que se arrogavam os verdadeiros democratas. Assim, ao justificar a necessidade de intervenção das Forças Armadas, o jornalista fluminense e outros 
correligionários astutamente conclamavam os "grupos esclarecidos" não para um golpe, mas para o que chamavam de um "contragolpe", que deporia um governo tido como inimigo da liberdade e prestes a "trair o país". Em certo sentido, ele e outros políticos antivarguistas pareciam imbuídos de um messianismo político que enxergava nos adversários conspiradores imorais a serem combatidos de todas as formas possíveis. $\mathrm{Na}$ sua visão maniqueísta, tratava-se de salvar o povo continuamente explorado por vilões corruptos e infiéis à nação.

Ao longo dos anos, o antiperonismo no Brasil passou por sutis transformações, com ênfase em alguns aspectos em detrimento de outros. Tais mudanças são compreensíveis tendo em conta que o próprio justicialismo, que possuía composição social bastante heterogênea, também enfrentou mutações. A partir dos anos iniciais da década de 1950, destacou-se especialmente a caracterização do regime platino como um governo muito próximo ideologicamente do comunismo. Especialmente nos editoriais de Carlos Lacerda, as consideráveis diferenças entre essas duas experiências políticas tenderam a ser deliberadamente ignoradas. Na lógica conservadora, peronismo e comunismo se assemelhavam em certa medida.

A derrota do pedido de impeachment de Vargas em 1954, feito com base em acusações de entendimentos secretos com Perón, não aplacou as especulações em torno de acordos confidenciais com a Casa Rosada. Como mostrou o grave episódio da carta Brandi, em 1955, o imaginário em torno de um conluio peronista continuou mobilizando muitos políticos udenistas que, com base naquele documento, conclamaram os militares a impedir a eleição e posse de João Goulart, principal herdeiro de Getúlio Vargas. Como se viu, a tentativa de intervenção no pleito por meio do "argumento argentino" malogrou fragorosamente e contribuiu, junto com a queda de Perón, para o enfraquecimento dessas representações nos anos seguintes no País.

Por fim, vale destacar que o antiperonismo no Brasil possuiu notórias semelhanças com aquele desenvolvido dentro na própria Argentina. Também estiveram muito presentes nos discursos dos opositores platinos a representação do justicialismo como uma espécie de nazismo, a visão negativa das massas, a denúncia constante do autoritarismo associado à figura Juan Manuel de Rosas e a crítica à aproximação com os comunistas no início dos anos 1950. Contribuiu para tais similitudes uma rede de colaboração e sociabilidade composta por oposicionistas brasileiros e antiperonistas platinos exilados principalmente no Uruguai. Em diversas ocasiões, periódicos liberaisconservadores do País franquearam suas páginas aos textos escritos por perseguidos 
políticos argentinos, principalmente pelos ex-deputados radicais Agustín Rodríguez Araya e Raúl Damonte Taborda.

Não se pode deixar de notar, porém, certa especificidade no discurso antiperonista brasileiro, especialmente a ênfase na política externa peronista supostamente imperialista e na mitologia em torno de conluios com políticos trabalhistas locais. Esses aspectos assumiram no País contornos bastante específicos que, como foi destacado, foram importantes nas disputas políticas daqueles anos. 


\section{Bibliografia}

ABREU, Alzira Alves de. A Imprensa em transição: o jornalismo brasileiro nos anos 50. Rio de Janeiro, Editora Fundação Getulio Vargas, 1996.

"Revisitando os anos 1950 através da imprensa". In: BOTELHO, André. $O$ moderno em questão. A década de 1950 no Brasil. Rio de Janeiro, Topbooks, 2008.

ACCIOLY NETO, Antonio. O Império de Papel - Os bastidores de O Cruzeiro, Porto Alegre: Sulina, 1998.

AFONSO, Eduardo José. Para norte-americano ver. Adidos Trabalhistas e operários brasileiros (1943/1952). Tese de Doutorado (História Social). São Paulo: FFLCH/USP, 2011.

ALMEIDA, Hamilton. Sob os olhos de Perón: o Brasil de Vargas e as relações com a Argentina. Rio de Janeiro: Record, 2005.

ALMEIDA, Paulo Renan de. Perón - Vargas - Ibáñez. Pacto ABC: raízes do Mercosul. Porto Alegre: EDIPUCRS, 1998.

BACZKO, Bronislaw. "Imaginação Social". In: Enciclopédia Einaudi (AnthroposHomem). Lisboa: Imprensa Nacional/Casa da Moeda, 1985, v. 5.

BAITZ, Rafael. Um continente em foco: a imagem fotográfica da América Latina nas revistas semanais brasileiras (1954-1964). São Paulo, Humanitas/História Social-USP, 2003.

BANDEIRA, Luiz Alberto Moniz. Brasil, Argentina e Estados Unidos: conflito e integração na América do Sul (da Tríplice Aliança ao Mercosul), 18702007. $3^{a}$ edição revisada e ampliada. Rio de Janeiro, Civilização Brasileira, 2010.

BEIRED, Jose Luis Bendicho. “A 'Grande Argentina': um Sonho Nacionalista para a Construção de uma Potência na América Latina". Revista Brasileira de História (Online), São Paulo, v. 21, n.42, 2001.

BENEVIDES, Maria Victoria de Mesquita. A UDN e o udenismo - ambiguidades do liberalismo brasileiro (1945-1965). Rio de Janeiro: Paz e Terra, 1981.

BOHOSLAVSKY, Ernesto. “Antiperonismo y Antivarguismo (1943-1955): Similitudes, diferencias, vínculos". Anuario $N^{\circ} 24$, Escuela de Historia, Universidad Nacional de Rosario, Revista Digital No. 3 (2011-2012).

CADERNOS DE COMUNICAÇÃO. O Cruzeiro - A maior e melhor revista da América Latina, Série Memória, vol. 3, Secretaria Especial de Comunicação Social, Prefeitura Municipal do Rio de Janeiro, Rio de Janeiro, 2002.

CANE, James. The fourth enemy. Journalism and Power in the making of peronist Argentina, 1930-1955. The Pennsylvania State University, Pennsylvania, 2011.

CAPELATO, Maria Helena Rolim e PRADO, Maria Lígia. O Bravo Matutino: imprensa e ideologia: o jornal $O$ Estado de S. Paulo. São Paulo: AlfaOmega, 1980.

Os Intérpretes das Luzes: Liberalismo e Imprensa Paulista (1920-1945). Doutorado em História Social. Universidade de São Paulo, USP, 1986.

"História Política" IN Estudos Históricos, Vol. 9, No 17, Rio de Janeiro: CPDOC/FGV, 1996.

"Populismo latino-americano em discussão". In: FERREIRA, Jorge (org). $O$ populismo e sua história: debate e crítica. Rio de Janeiro: Civilização Brasileira, 2001, p. 127-165. 
. Multidões em Cena: Propaganda Política no Varguismo e no Peronismo. 2a edição. São Paulo: Editora UNESP, 2008.

CARLONI, Karla Guilherme. Marechal Lott, a opção das esquerdas: uma biografia política. Rio de Janeiro, Garamond, 2014.

CARNEIRO, Glauco. Lusardo: o último caudilho: entre Vargas e Perón. Vol. 2. Rio de Janeiro: Nova Fronteira, 1978.

CARVALHO, Luis Maklouf. Cobras Criadas: David Nasser e O Cruzeiro. São Paulo, editora SENAC, 2001.

CASADEI, Eliza Bachega. "O sonho imperialista de Assis Chateaubriand na América Latina: ascensão e fracasso de "O Cruzeiro Internacional"". Revista Extraprensa, v. 1, p. 75-87, 2012.

CAVLAK, Iuri. A política externa brasileira e a Argentina Peronista (1946-1955). São Paulo, Annablume, 2008.

"Nazismo na América do Sul: A questão do peronismo". Boletim Tempo Presente (UFRJ), v. 8, 2013.

CHARTIER, Roger. A História Cultural: entre práticas e representações. Tradução de Maria Manuela Galhardo, Lisboa, Difel, 1990.

CISNEROS, Andrés \& IÑIGUEZ, Carlos Piñeiro. Del ABC al Mercosur: la integración latinoamericana em la doctrina y práxis del peronismo. Buenos Aires: ISEN/Nuevo Hacer/Grupo Editor Latinoamericano, 2002, 601 p.

COSTA, Helouise. Aprenda a ver as coisas: fotojornalismo e modernidade na revista $\mathrm{O}$ Cruzeiro, dissertação de mestrado. São Paulo: ECA-USP, 1992.

Um olho que pensa: estética moderna e fotojornalismo, Tese de doutorado. São Paulo: FAU-USP, 1998.

COSTA, Marcelo Fernandes González da. As repercussões da política externa Argentina no primeiro Governo Perón (1946-1952) na imprensa Sul-RioGrandense. Dissertação de mestrado, São Leopoldo, Universidade do Vale do Rio dos Sinos (UNISINOS), 2004.

COUTINHO, Lourival, O General Góes Depõe..., Editora Coelho Branco, 1956.

CRUZ, Adelina Novaes; COSTA, Celia Maria Leite; D’ARAÙJO, Maria Celina Soares; SILVA, Suely Braga da (orgs.). Impasse na democracia brasileira (19511955): Coletânea de documentos. Rio de Janeiro: Fundação Getúlio Vargas, 1983.

D’ARAÚJO, Maria Celina Soares, O Segundo Governo Vargas, 1951-1954. Rio de Janeiro: Zahar, 1982.

DELGADO, Marcio de Paiva. O "golpismo democrático". Carlos Lacerda e o jornal Tribuna da Imprensa na quebra da legalidade (1949-1964). Dissertação de Mestrado, Universidade Federal de Juiz de Fora (UFJF), 2006.

DEVOTO, Leonor Machinandiarena de. Las relaciones con Chile durante el peronismo: 1946-1955. 1ª. Ed., Buenos Aires, Lumière, 2005.

DORATIOTO, Francisco. Maldita guerra: nova história da Guerra do Paraguai. São Paulo: Companhia das Letras, 2002.

DOYON, Louise. "La formación del sindicalismo peronista" In Juan Carlos Torre (dir.) Nueva Historia Argentina. Los años peronistas (1943-1955). Buenos Aires, Sudamericana, 2002, Tomo VIII.

DRUMOND, Maurício. Nações em jogo: esporte e propaganda política em Vargas e Perón. Rio de Janeiro: Apicuri, 2008.

DULLES, John W. Foster. Carlos Lacerda: a vida de um lutador (1914-1960). Rio de Janeiro, Nova Fronteira, 1992, v.1. 
FERRARO, Alceu Ravanello. "Analfabetismo e níveis de letramento no Brasil: o que dizem os censos?”. Educ. Soc., Campinas , v. 23, n. 81, Dec. 2002 . Disponível em <http://www.scielo.br/scielo.php?script=sci_arttext\&pid=S0101$73302002008100003 \& \operatorname{lng}=$ en\&nrm=iso>. Acesso em 14 Jan. 2015.

FERREIRA, Jorge. O imaginário trabalhista: getulismo, PTB e cultura política popular (1945-1964). Rio de Janeiro, Civilização Brasileira, 2005.

"O nome e a coisa: o populismo na política brasileira". In: (Org.). $O$ populismo e sua história: debate e crítica. Rio de Janeiro: Civilização Brasileira, 2001.

. O Rio de Janeiro nos jornais: ideologias, culturas políticas e conflitos sociais (1946-1964). Rio de Janeiro: 7 Letras, 2011.

FONTICELLI, Marcelo; PANELLA, Claudio. La prensa de izquierda y el peronismo (1943-1949). Socialistas y comunistas frente a Perón. $1^{\mathrm{a}}$ Ed., La Plata, Universid Nacional de La Plata, 2007.

FONTOURA, João Neves da. Depoimentos de um ex-ministro (peronismo - minerais atómicos - política externa). Rio de Janeiro, Organização Simões Editora, 1957.

FRIAS FILHO, Otavio. "O Tribuno da Imprensa” In Piauí, Rio de Janeiro, no. 91, ano 8, abril de 2014.

GIRARDET, Raoul. Mitos e Mitologias Políticas. Tradução de Maria Lúcia Machado. São Paulo: Companhia das Letras, 1987.

GOMES, Angela de Angela de Castro. "Jango e a República de 1945-1964: da República Populista à Terceira República", in: Rachel Soihet; Maria Regina Celestino Almeida; Cecília Azevedo; Rebeca Gontijo (orgs.). Mitos, projetos e práticas políticas. Memória e historiografia. Rio de Janeiro, Civilização Brasileira, 2009.

HAUSSEN, Dóris Fagundes. Rádio e política: tempos de Vargas e Perón. São Paulo, 1992, Tese de doutorado, Universidade de São Paulo (USP).

HIRST, Monica. "Vargas y Perón. Las relaciones argentino brasileñas" In Todo es Historia, no. 224, Buenos Aires, deciembre 1985.

O Pragmatismo Impossível: A Política Externa do Segundo Governo Vargas. Rio de Janeiro: Editora do CPDOC, 1990.

JULLIARD, Jacques. "A política". In: LE GOFF, Jacques e NORA, Pierre (org.) História: novas abordagens. Rio de Janeiro: Francisco Alves, 1976.

LACERDA, Carlos. Depoimento. Rio de Janeiro, Nova Fronteira, 1978.

PESAVENTO, Sandra Jatahy. "Em Busca de Uma Outra História: Imaginando o imaginário". Revista Brasileira de História, São Paulo, v. 15, n. 29, 1995.

LIMA, Herman. História da Caricatura no Brasil. Rio de Janeiro: José Olympio Ed., $1963,4^{\circ}$ volume.

LUCA, Tania Regina de. "História dos, nos e por meio dos periódicos". In: PINSKY, Carla Bassanezi (org.). Fontes históricas. São Paulo: Contexto, 2005.

LUNA, Félix. Perón y su tiempo: la Argentina era una fiesta - 1946-1949. Buenos Aires: Sudamericana, 1986.

Perón y su tiempo. II - La comunidad organizada (1950-1952). Editorial Sudamericana, Buenos Aires, 1985.

MENDONÇA, Marina Gusmão de. O demolidor de presidentes. São Paulo: Códex, 2002, 2a . Edição.

MORAES, Letícia Nunes de Góes. "David Nasser e a conspiração de 1964", in: Revista Tempo Brasileiro, Rio de Janeiro, 158: 137/162, jul.-set., 2004. 
MORAES, Letícia Nunes de. Cotidiano e Política em Carmen da Silva e David Nasser (1963-1973). Tese apresentada ao Departamento de História da Faculdade de Filosofia, Letras e Ciências Humanas da Universidade de São Paulo, 2007.

MOTTA, Rodrigo Patto Sá. Em guarda contra o perigo vermelho: o anticomunismo no Brasil. São Paulo, Perspectiva/FAPESP, 2002.

Jango e o golpe de 1964 na caricatura. Rio de Janeiro, Jorge Zahar Ed., 2006.

NETO, Lira. Getúlio: Da volta pela consagração popular ao suicídio (1945-1954). $1^{\mathrm{a}}$. edição, São Paulo, Companhia das Letras, 2014.

PANELLA, Claudio. La prensa de izquierda y el peronismo (1943-1949): socialistas y comunistas frente a Perón. La Plata, Universidad Nacional de La Plata, 2007.

"Los agregados obreros" In Revista Todo es Historia, n 328, octubre 1994.

PARADISO, José. "Vicisitudes de una política exterior independiente" In TORRE, Juan Carlos (org.). Nueva Historia Argentina. Tomo VIII. Los años peronistas (1943-1955), Buenos Aires, Ed. Sudamericana, 2002.

PEREGRINO, Nadja. A fotografia de reportagem: sua importância na revista $\mathrm{O}$ Cruzeiro (1944-1960), Dissertação de mestrado, Escola de Comunicação da Universidade Federal do Rio de Janeiro, Rio de Janeiro, 1990.

PRADO, Maria Ligia C.."O Brasil e a distante América do Sul". Revista de Historia (USP), São Paulo, v. 145, 2001.

RECKZIEGEL, Ana Luiza. O Pacto ABC: As Relações Brasil-Argentina na Década de 1950. Passo Fundo: EDIUPF, 1996.

REICHEL, H. J. "Sob os olhos da águia: imagens da Argentina peronista na imprensa brasileira dos primeiros anos da guerra-fria (1946-1955)". Revista Eletrônica da ANPHLAC, v. 7, p. 76, 2008.

RÉMOND, Rene. "Uma história presente". In: RÉMOND, Rene. (org.). Por uma história política. Rio de Janeiro: FGV, 1996.

RIBEIRO, Ana Paula Goulart. Imprensa e história no Rio de Janeiro dos anos 1950. Rio de Janeiro: E-papers, 2007.

RIBEIRO, Vanderlei Vazelesk. A Roça y la Campaña: a questão agrária face ao Varguismo e ao Peronismo. Tese de doutorado, Niterói, UFF, 2006.

ROSANVALLON, Pierre. "Por uma história conceitual do político" In: Por uma história conceitual do político. São Paulo, Alameda, 2010.

SAAVEDRA, Marisol; "Peronismo y antiperonismo en Chile y Brasil" In Todo es Historia, no 369 , abril de 1998, p. 8 a 34.

SANTOS, Daniella Xavier. Vargas e Perón: A Política Externa do Brasil para a Argentina na Primeira Metade da Década de 1950. Dissertação de mestrado. Universidade de Brasília, 1991.

SANTOS, Raquel Paz dos. "O impacto do projeto do ABC nas relações BrasilArgentina durante o segundo governo Vargas" In OPSIS, Catalão-GO, v. 14, n. especial, 2014, p. 38-59.

SCHEMES, Cláudia. As festas cívicas e esportivas no populismo: um estudo comparado dos governos Vargas (1937-1945) e Perón (1946-1955). São Paulo, 1995, Dissertação de mestrado, Universidade de São Paulo (USP).

SEBASTIANI, Marcela García. Los antiperonistas en la Argentina peronista: radicales y socialistas en la política argentina entre 1943 y 1951. 1ª ed. Buenos Aires: Prometeo Libros, 2005.

SILVA, Carlos Eduardo Lins da. O adiantado da hora : a influência americana sobre o jornalismo brasileiro. São Paulo: Summus, 1991. 
SIRVÉN, Pablo. Perón y los medios de comunicación. La conflictiva relación de los gobiernos justicialistas com la prensa (1943-2011). 1ª . edição, Buenos Aires, Sudamericana, 2011.

SKIDMORE, Thomas. Brasil: de Getúlio a Castelo. 7. ed. Rio de Janeiro: Paz e Terra, 1982.

SOARES, Gláucio Ary Dillon. "As bases ideológicas do lacerdismo" In Revista Civilização Brasileira, ano I, No. 4, Rio de Janeiro, setembro, 1965, p. 4970.

TORRE, Juan Carlos, "Introducción a los años peronistas" In Juan Carlos Torre (dir.) Nueva Historia Argentina. Los años peronistas (1943-1955), Buenos Aires, Sudamericana, 2002, Tomo VIII.

VÁZQUEZ, Pablo Adrián. “Argentina y URSS. Relaciones comerciales y culturales durante los gobiernos de Perón" In Actas del Primer Congreso de estudios sobre el peronismo: la primera década. Mar del Plata, Noviembre de 2008. Disponível

on-line http://redesperonismo.com.ar/archivos/CD1/EPP/vazquez.pdf . Acesso em 12/12/2014.

WAINER, Samuel. Minha razão de viver. Rio de Janeiro: Record, 1987.

WEBER, Hilde. O Brasil em charge: 1950-1985. São Paulo: Circo Editorial, 1986. 


\section{Anexos}

\section{a) Lista de fontes}

\section{Livros da época}

LACERDA, Carlos. “A Traição em Marcha” In Tribuna da Imprensa, Rio de Janeiro, 29-30/10/1955, 24 p. (Suplemento especial). (Acervo Carlos Lacerda UNB).

MARTINS, Mário. Perón: um confronto entre o Brasil e a Argentina. Rio de Janeiro: Edições do Povo, 1950.

NETTO, A. Accioly. Três mascaras. Rio de Janeiro, Editora "O Cruzeiro", 1956.

NUÑEZ ARCA, P. e PLANTÓN, Juan Pedro. A verdade argentina: a luta de um povo por sua liberdade econômica. São Paulo, Letras Editora Continental, 1950, $112 \mathrm{p}$.

De Quitandinha a Bogotá passando por Buenos Aires: reportagens de duas conferencias e duas viagens. São Paulo : Letras Ed. Continental, s/d, 278 p.

PERÓN, Juan Domingo. La hora de los pueblos. Buenos Aires: Norte, 1968.

TABORDA, Raul Damonte. O caso Perón: uma conspiração internacional. Porto Alegre: Globo, 1954.

\section{Lista cronológica das matérias publicadas pela revista $O$ Cruzeiro que fazem referência ao peronismo (outubro de 1945 a dezembro de 1955)}

OLIVEIRA, Franklin. Coluna: Sete Dias In O Cruzeiro, Rio de Janeiro, 15/12/1945.

NASSER, David e MANZON, Jean. "A mulher de Perón” In O Cruzeiro, Rio de Janeiro, 1/06/1946, p. 6, 8-16.

NASSER, David. "Contrabando no sul” In O Cruzeiro, Rio de Janeiro, 23/11/1946, p. 34,35 e 44.

NASSER, David e MANZON, Jean. "Com os rebeldes no Paraguai" in O Cruzeiro, Rio de Janeiro, 05/04/1947, p. 8-16, 50, 74 e 84.

WAINER, Samuel. "Óleo para a grande aventura do general Perón” in O Cruzeiro, Rio de Janeiro,10/05/1947, p. 34-36 e 40.

FREITAS, Geraldo de e REGATO, Angelo. "Novas pontes ligam a América" in $O$ Cruzeiro, Rio de Janeiro, 14/06/1947, p. 56-62.

NASSER, David e MANZON, Jean. "Nosso amigo Videla" in O Cruzeiro, Rio de Janeiro, 05/07/1947, p. 64- 66, 80 e 84.

PEARSON, Drew. "Perón busca o apoio brasileiro" in O Cruzeiro, Rio de Janeiro, 26/07/1947, p. 16.

PEARSON, Drew. "Wallace aproxima-se de Truman" in O Cruzeiro, Rio de Janeiro, 2/08/47, p. 64.

CECÍLIA, Helena. "Viagem da Peregrina" In O Cruzeiro, Rio de Janeiro, 9/08/1947, p. 3

PEARSON, Drew. "A Argentina auxilia Morinigo" In O Cruzeiro, Rio de Janeiro, 09/08/1947, p. 16 e 17. 
PEARSON, Drew. "A carne argentina e a rainha Elisabeth" In O Cruzeiro, Rio de Janeiro, 16/08/1947, p. 34.

PEARSON, Drew. "Perón agrada os Estados Unidos" In O Cruzeiro, Rio de Janeiro, 23/08/1947, p. 16

MANZON, Jean. "Os descamisados" In O Cruzeiro, Rio de Janeiro, 6/09/1947, p. 9-15.

PEARSON, Drew. "Reconstrução da Alemanha" In O Cruzeiro, Rio de Janeiro, 13/09/1947, p. 16.

PEARSON, Drew. "Londres prepara nova crise para os EE. UU." In O Cruzeiro, Rio de Janeiro, 20/9/1947, p. 16.

NASSER, David. "O perigo argentino" In O Cruzeiro, Rio de Janeiro, 11/10/1947, p. 31.

PEARSON, Drew. "A Argentina no Conselho de segurança da ONU” In O Cruzeiro, Rio de Janeiro, 01/11/1947, p. 16.

PEARSON, Drew. "Perón tentou intervir no Paraguai" In O Cruzeiro, Rio de Janeiro, 10/1/1948, p. 16.

PEARSON, Drew. "Trigo - baluarte da Argentina" In O Cruzeiro, Rio de Janeiro, 17/1/1948, p. 40.

SILVA, Arlindo. "Ponta de lança dos descamisados" In O Cruzeiro, Rio de Janeiro, 31/1/1948, p. 36-28 e 56

PEARSON, Drew . "Livro branco contra Trujillo" In O Cruzeiro, Rio de Janeiro, 21/2/1948, p. 34.

PEARSON, Drew. "Drew: "Perón nega carne à Argentina" In O Cruzeiro, Rio de Janeiro, 6/3/1948, p. 32.

MANZON, Jean. "Do samba ao tango" In O Cruzeiro, Rio de Janeiro, 17/4/1948, p. 5457.

PEARSON, Drew. "Perón contra o continente" In O Cruzeiro, Rio de Janeiro, 15/05/1948, p. 34.

PERSON, Drew. "Truman ainda espera ser candidato" In O Cruzeiro, Rio de Janeiro, 22/05/1948, p. 34.

NASSER, David e SCLIAR, Salomão. "Pão nosso de cada dia - A vergonha do trigo" In O Cruzeiro, Rio de Janeiro, 29/05/1948, p. 8-14,16.

PERSON, Drew. "A Argentina pretende dominar a América" In O Cruzeiro, Rio de Janeiro, 29/05/1948, p. 64.

PEARSON, Drew. "A Conferência de Bogotá foi um fracasso" In O Cruzeiro, Rio de Janeiro, 5/6/1948, p. 58

PEARSON, Drew. “Terror em Buenos Aires” In O Cruzeiro, Rio de Janeiro, 26/6/1948, p. 24

PEARSON, Drew. "Perón intervirá no Paraguai" In O Cruzeiro, Rio de Janeiro, 24/7/1948, p. 32.

WAINER, Samuel. "Venezuela - nação afogada em petróleo" In O Cruzeiro, Rio de Janeiro, 25/09/1948, n. 49, ano XX.

PEARSON, Drew: "Frente anticomunista na Ásia" In O Cruzeiro, Rio de Janeiro, 2/10/1948, p. 45

PEARSON, Drew. "Exemplo de justiça peronista" O Cruzeiro, Rio de Janeiro, 30/10/1948, p. 46.

PEARSON, Drew. "O “Complot” contra Perón” In O Cruzeiro, Rio de Janeiro, 06 de novembro de 1948, n. 3, ano XXI.

PEARSON, Drew. "A América Latina apoiará os EE. UU.?" In O Cruzeiro, Rio de Janeiro, 20 de novembro de 1948, n. 5, ano XXI. 
PEARSON, Drew. "O plano quinquenal argentino" In O Cruzeiro, Rio de Janeiro, 8/1/1949, p. 64.

GUIMARÃES, Josué. "Trigo - a nova batalha do Brasil” In O Cruzeiro, Rio de Janeiro, 22/1/1949, p. 42-48; 52

NASSER, David e MANZON, Jean. "Bancarrota Argentina" In O Cruzeiro, Rio de Janeiro, 12/2/1949, p. 12- 20 e 24.

NASSER, David “Lama das botas de Perón” In O Cruzeiro, Rio de Janeiro, 19/2/1949, p. 43 e 44.

PEARSON, Drew. A nação menos democrática da América Latina In O Cruzeiro, Rio de Janeiro, 12 de março de 1949, n. 21, ano XXI.

PEARSON, Drew "Receia-se nos EE.UU uma revolução no Brasil” In O Cruzeiro, Rio de Janeiro, 19/3/1949, p. 96.

PEARSON, Drew. "Argentina não quer turistas" In O Cruzeiro, Rio de Janeiro, 09/4/49, p. 68.

NASSER, David. "Só a morte calará a minha voz" In O Cruzeiro, Rio de Janeiro, 23/4/1949, n. 27, ano XXI.

NASSER, David. "Espionagem de Perón no Brasil - Os agentes argentinos no Rio" IN O Cruzeiro, Rio de Janeiro, 30/4/1949, n. 28, ano XXI.

NASSER, David. "Espionagem de Perón no Brasil - Documento revelador" In $O$ Cruzeiro, Rio de Janeiro, 7/5/1949, p. 28 e 78.

SILVA, Álvares da e SILVA, Eugenio H.. "O mistério dos 3 Peróns" In O Cruzeiro, Rio de Janeiro, 21/5/1949, p. 62-65, 78, 80.

JORDÃO, Vera Pacheco. "Nuestra Argentina" In O Cruzeiro, Rio de Janeiro, 9/7/49, p. 3.

GUIMARÃES, Josué e KEFFEL, Ed.. "Sentinelas da fronteira" In O Cruzeiro, Rio de Janeiro, 16/7/49, p. 58-62; 66.

FERREIRA, Jorge; BALLOT, Henri e MARTINS, João. "Vargas rumo ao Catete" In $O$ Cruzeiro, Rio de Janeiro, 10/02/1951.

PEARSON, Drew. “As catástrofes começam no verão" In O Cruzeiro, Rio de Janeiro, 27/8/49, p. 70

PEARSON, Drew. "A bomba atômica russa". Coluna "O Carrossel do mundo" In $O$ Cruzeiro, Rio de Janeiro, 29/10/1949, p. 38.

PEARSON, Drew. "Automóveis americanos no Brasil" In O Cruzeiro, Rio de Janeiro, 25/2/1950, p. 62.

NASSER, David e MANZON, Jean. "A rebelde Bolívia - Sangue, estanho e dinamite" In O Cruzeiro, Rio de Janeiro, 18/3/1950, p. 12-22, 28, 32 e 96.

GUIMARÃES, Josué e KEFFEL, Ed. "A tirania pelo medo - Os fugitivos de Perón (parte 1)". In O Cruzeiro, Rio de Janeiro, $1^{\circ}$ de abril de 1950, p. 41, 42, $48 \mathrm{e}$ 52.

PEARSON, Drew. "Carta aberta a Dean Acheson" In O Cruzeiro, Rio de Janeiro, $1^{\circ}$ de abril de 1950, p. 68.

GUIMARÃES, Josué e KEFFEL, Ed. ““Complôs de mentira” - Os fugitivos de Perón (parte 2)". In O Cruzeiro, Rio de Janeiro, 8 de abril de 1950, p. 44, 45, 46, 56, 74 e 68.

GUIMARÃES, Josué e KEFFEL, Ed. "Jornalismo - o maior inimigo das ditadura. Os fugitivos de Perón - parte III". In O Cruzeiro, Rio de Janeiro, 15 de abril de 1950, p. 44,45,46 e 64.

GUIMARÃES, Josué e KEFFEL, Ed. "Terror - a moderna arma da Argentina. Os fugitivos de Perón (parte IV)". O Cruzeiro, Rio de Janeiro, 29/4/1950, p. 51, 52 e 76. 
GUIMARÃES, Josué e KEFFEL, Ed. "Aluga-se uma revolução. Os fugitivos de Perón - (parte V)". O Cruzeiro, Rio de Janeiro, 6/5/1950, p. 51 e 70.

SILVA, Arlindo e SCHEIER, Peter. "Um caudilho no Uruguai" In O Cruzeiro, Rio de Janeiro, 13/5/1950.

PEARSON, Drew. "A luta de Videla contra o comunismo" In O Cruzeiro, Rio de Janeiro, 20/05/1950, p. 74.

PEARSON, Drew. "Vargas pretende reviver o comunismo" In O Cruzeiro, Rio de Janeiro, 03.06.1950, p. 78.

PEARSON, Drew. "125 milhões para a Argentina" In O Cruzeiro, Rio de Janeiro, 10.06.1950, p. 70.

NASSER, David e MANZON, Jean."Luzardo x Pereira Lira. Inquérito da traição" In $O$ Cruzeiro, Rio de Janeiro, 24/06/1950, p. 12, 13,14,15, 16, 22 e 122.

NASSER, David e MANZON, Jean. "Os tanks da democracia" In O Cruzeiro, Rio de Janeiro, 01/07/1950.

SILVA, Arlindo. "Lembrai-vos de 37!" In O Cruzeiro, Rio de Janeiro, 08/07/1950, p. 26-29, 86, 88 e 98.

QUEIROZ, Rachel de. "Eleições - partidos II" In O Cruzeiro, Rio de Janeiro, 22/7/1950, p. 130.

NASSER, David. "Marcado por Perón - o drama argentino" In O Cruzeiro, Rio de Janeiro, 30 de setembro de 1950, p. 25, 26 e 46.

NASSER, David e MANZON, Jean. "História secreta das eleições de 1950" In $O$ Cruzeiro, Rio de Janeiro, 30 de setembro de 1950, p. 12-18, 24 e 86.

NASSER, David. Perón insulta o Brasil: "Uma república de bêbedos" In O Cruzeiro, Rio de Janeiro, 7/10/1950, p. 15, 16, 17, 18 e 20.

LAUS, Lausimar." Buenos Ayres" In O Cruzeiro, Rio de Janeiro, 7/10/1950, p. 3.

CAMARINHA, Mario e FREUND, Gisele. "A vida íntima de Eva Perón" In: $O$ Cruzeiro, Rio de Janeiro, 20/01/1951

WAINER, Samuel. "A força da democracia - A volta de Vargas" In O Cruzeiro, Rio de Janeiro, 27/01/1951, p. 46, 47 e 84.

OLIVEIRA, Franklin de. "Os mortos ceiam" In O Cruzeiro, Rio de Janeiro, 24.02.1951, p. 7.

OLIVEIRA, Franklin. "Violência e ignomínia". Coluna Sete Dias In: O Cruzeiro, Rio de Janeiro, 17 de março de 1951, p. 7.

LAUS, Lausimar. "Uma brasileira visita La Prensa" In O Cruzeiro, Rio de Janeiro, 24/3/1951, p. 3.

OLIVEIRA, Franklin de. "Golpe e ameaça argentinos, dever brasileiro". Coluna Sete Dias In: O Cruzeiro, Rio de Janeiro, 7 de abril de 1951, p. 7.

QUEIROZ, Rachel de. "O drama de "La prensa"” In O Cruzeiro, Rio de Janeiro, 21/04/1951, p. 130.

RODRIGUEZ-ARAYA, Agustin e KEFFEL, Ed. "La Prensa - O baluarte ultrajado" In O Cruzeiro, Rio de Janeiro, 5/5/1951, p. 95, 96, 97, 98, 99, 100, 104 e 112.

PEARSON, Drew. "O Queixo de vidro de Perón" In O Cruzeiro, Rio de Janeiro, 21/07/1951, p. 72.

MOREIRA, Neiva e KANAI, Utaro. "Há uma força em meu caminho" In O Cruzeiro, Rio de Janeiro, 28 de julho de 1951, p. 81-84, 88, 90 e 98.

PEARSON, Drew. "Einsenhower e a Casa Branca" In O Cruzeiro, Rio de Janeiro, 11.08.1951, p. 78.

PEARSON, Drew. "A vice-presidente Evita..." In O Cruzeiro, Rio de Janeiro, 01.09.1951, p. 62. 
DAMM, Flavio. "Perón não tem a bomba atômica" In: O Cruzeiro, Rio de Janeiro, 22/9/1951, p. 12-16, 18 e 48.

NASSER, David e WANDERLEY, Indalecio. "Perón balança, mas não cai" IN $O$ Cruzeiro, Rio de Janeiro, 20 de setembro de 1951, p. 12-20 e 26.

PEARSON, Drew. "Perón e o vice-reinado do Prata". Coluna Carrossel do Mundo IN $O$ Cruzeiro, Rio de Janeiro, 20 de setembro de 1951, p. 74.

SILVA, Camarinha da. "Fracasso dos peronistas da imprensa" IN O Cruzeiro, Rio de Janeiro, 3/11/1951, p. 34, 35, 36, 44, 45, 50.

PEARSON, Drew. "É tarde demais para agir no Irã" In O Cruzeiro, Rio de Janeiro, $17 / 11 / 1951$.

PEARSON, Drew. "Propostas de paz na Europa" In O Cruzeiro, Rio de Janeiro, 15/12/1951, p. 82.

PEARSON, Drew. "Expurgo de militares argentinos" In O Cruzeiro, Rio de Janeiro, 05/01/1952, p. 60.

PEARSON, Drew. "Perón não confia no Exército" In O Cruzeiro, Rio de Janeiro, 16/12/1952, p. 80.

NASSER, David e KANAI, Utaro. "Falsos turistas na Argentina" IN O Cruzeiro, Rio de Janeiro, 5/4/1952, p. 12-18, 56-57.

MOREIRA, Neiva e DAMM, Flavio. "O terror invade La Paz - Oito milhões de tiros na Revolução da Bolívia" In O Cruzeiro, Rio de Janeiro, 10 de maio de 1952.

MOREIRA, Neiva e DAMM, Flavio. "Estenssoro rasga o jogo da nacionalização" In $O$ Cruzeiro, Rio de Janeiro, 17 de maio de 1952, p. 84-88, 90, 98, 108.

FERREIRA, Jorge e LEITE, Nicolas. "Os últimos dias de Eva Perón” In O Cruzeiro, Rio de Janeiro, 17 de maio de 1952.

PEARSON, Drew. "Por trás da revolução boliviana" n $O$ Cruzeiro, Rio de Janeiro, 31/05/1952, p. 46.

ANDRADE, Theophilo de. "Perón e os métodos de tortura de sua "Gestapo"” In $O$ Cruzeiro, Rio de Janeiro, 7/06/1952, p. 45.

ANDRADE, Theophilo de. "Perón cumple" In O Cruzeiro, Rio de Janeiro, 28/06/1952, p. 53.

PEREIRA, Alceu. "Faleceu Eva Duarte Perón” O Cruzeiro, Rio de Janeiro, 09/08/1952, p. 121-124

QUEIROZ, Rachel de. "Evita” In O Cruzeiro, Rio de Janeiro, 16/8/1952.

ASSIS, Nelson de e RONEK, Antônio. "Fronteira sangrenta" In O Cruzeiro, Rio de Janeiro, 23/8/1952.

CAMARINHA, Mario. "Com pompas nunca vistas - Os funerais de Eva Duarte Perón", O Cruzeiro, Rio de Janeiro, 30/08/1952.

PEARSON, Drew. "A Força Aérea e os discos voadores", In O Cruzeiro, Rio de Janeiro, 6/9/1952, p. 110.

NASSER, David e KEFFEL, Ed. "Perón denunciado às Nações Unidas" In O Cruzeiro, Rio de Janeiro, 13/9/1952.

CARIDE, Alberto. "As câmaras de tortura de Perón" In O Cruzeiro, Rio de Janeiro, 20/09/1952.

ANDRADE, Theophilo de. "Caudilhos \& Pronunciamentos" In O Cruzeiro, Rio de Janeiro, 27/9/1952, p. 14.

CARIDE, Alberto. "As câmaras de tortura de Perón - O martírio de Mário Bravo" In $O$ Cruzeiro, Rio de Janeiro, 27/09/1952.

ATHAYDE, Austregésilo de. "Volta a D. Quixote" In O Cruzeiro, 4/10/1952, p. 4. 
NASSER, David e KEFFEL, Ed. "Pimenta nos olhos dos outros - Entrei duas vezes na câmara de tortura" IN $O$ Cruzeiro, Rio de Janeiro, 11/10/1952, 50-52, 62, 72 e 48.

NASSER, David e KEFFEL, Ed. "Pimenta nos olhos dos outros - O suplício das telefonistas" In O Cruzeiro, Rio de Janeiro, 18/10/1952.

ANDRADE, Theophilo de. "Uruguai, democracia exemplar" In O Cruzeiro, Rio de Janeiro, 8/11/1952.

PEARSON, Drew. "A viagem de Einsenhower à Coreia" In O Cruzeiro, Rio de Janeiro, 20/12/1952, p. 24.

MOREIRA, Neiva e DAMM, Flavio. "Perón assalta o Uruguai" In O Cruzeiro, Rio de Janeiro, 3/1/1953.

ANDRADE, Theophilo de. "Calendário das ditaduras sul-americanas" In O Cruzeiro, Rio de Janeiro, 3/1/1953, p. 14.

MOREIRA, Neiva e DAMM, Flavio. "Colegiado, antibiótico do golpismo e da corrupção" In O Cruzeiro, Rio de Janeiro, 10/1/1953.

AGUIAR, Wilson e SILVA, Eugenio. "Perón desmascarado no Chile. Beijos e 30 dinheiros" In O Cruzeiro, Rio de Janeiro, 11/4/1953.

AGUIAR, Wilson e SILVA, Eugenio. "A Eva Perón do Chile" In O Cruzeiro, Rio de Janeiro, 02/05/1953.

PEARSON, Drew. "Aperfeiçoamentos nas Bomba Atômicas" In O Cruzeiro, Rio de Janeiro, 2/5/1953.

ANDRADE, Theóphilo de. “As táticas de Perón” In O Cruzeiro, Rio de Janeiro, 09/05/1953.

PEARSON, Drew. "Por que se suicidou o cunhado de Perón" In O Cruzeiro, Rio de Janeiro, 23/05/1953.

LEMOS, Ubiratan e WANDERLEY, Indalécio. "Bolívia - Maldição do Estanho" In $O$ Cruzeiro, Rio de Janeiro, 23/05/1953.

MENDONÇA, Yedo e AUDI, Jorge. "Perón Contra Evita" In O Cruzeiro, Rio de Janeiro, 13/6/1953.

MENDONÇA, Yedo. “Juan Duarte” In O Cruzeiro, Rio de Janeiro, 20/6/1953.

ANDRADE, Theophilo. "A Argentina sob o terror" In O Cruzeiro, Rio de Janeiro, 20/6/1953

OLIVEIRA, Franklin de. "A volta da vovó". Coluna Sete Dias In O Cruzeiro, Rio de Janeiro, 11/7/1953.

MENDONÇA, Yedo e AUDI, Jorge. "Enquanto Perón não cai... o terror domina Buenos Aires" In O Cruzeiro, Rio de Janeiro, 18/7/1953.

MENDONÇA, YEDO e BERTO, Nélio. "1a. bomba de Jango - Revolução Trabalhista" In O Cruzeiro, Rio de Janeiro, 18/7/1953.

NASSER, David. "Menina de 4 anos expulsa por Perón" In O Cruzeiro, Rio de Janeiro, 5/9/1953.

MENDONÇA, Yedo e DAMM, Flávio. "Acabou-se o ABC - Novos tratados BrasilPeru" In O Cruzeiro, Rio de Janeiro, 12/9/1953.

NASSER, David. "Resposta ao governo da Bolívia - Fantoche de Perón" In O Cruzeiro, Rio de Janeiro, 26/9/1953.

PEARSON, Drew. "Perón e a visita de Milton Eisenhower" In O Cruzeiro, Rio de Janeiro, 26/9/1953.

NASSER, David. "Argentina, república do medo - A mulher que fugiu do inferno" In $O$ Cruzeiro, Rio de Janeiro, 10/10/1953.

MARTINS, João. "Dois bilhões de dólares em pão" In O Cruzeiro, Rio de Janeiro, 19/12/1953. 
LAUS, Lausimar. "A linguagem do silêncio" In O Cruzeiro, Rio de Janeiro, 2/1/1954.

MENDONÇA, Yedo e RONEK, Antônio. "O bonitão dos pampas" In O Cruzeiro, Rio de Janeiro, 09/01/1954.

ATHAYDE, Austregésilo de. "Duas nações inseparáveis" In O Cruzeiro, Rio de Janeiro, 01/05/1954.

PEARSON, Drew. "Os EE. UU. E a guerra da Indo-china" In O Cruzeiro, Rio de Janeiro, 15/05/1954, p. 84.

MARTINS, João e RONEK, Antônio. "Nos bastidores da intriga internacional - Política e sangue no Paraguai" In O Cruzeiro, Rio de Janeiro, 12/06/1954.

“ 'Carlos Gardel', o tango proibido" In O Cruzeiro, Rio de Janeiro, 19/06/1954.

PEARSON, Drew. "A revolta no Paraguai e Perón” In O Cruzeiro, Rio de Janeiro, $10 / 7 / 1954$.

FERREIRA, Jorge e PINTO, José. "Perón invade o Paraguai" In O Cruzeiro, Rio de Janeiro, 27/11/1954.

GASPAR, Carlos."Perón contra a Igreja" In O Cruzeiro, Rio de Janeiro, 15/1/1955.

ATHAYDE, Austregésilo de. "Poder e glória" In O Cruzeiro, Rio de Janeiro, 4/6/1955.

SILVA, Arlindo e DAMM, Flavio. "Fugitivos do inferno Peronista" In O Cruzeiro, Rio de Janeiro, 11/6/1955.

SILVA, Arlindo. "Ordem: matar Perón" In O Cruzeiro, Rio de Janeiro, 2/7/1955.

SILVA, Arlindo e DAMM, Flavio. "Eis um dos motivos da Revolução - Santa EVITA" In O Cruzeiro, Rio de Janeiro, 2/7/1955

ANDRADE, Theophilo de. "O excomungado" In O Cruzeiro, Rio de Janeiro, 9/7/1955.

CARDOSO, Lycurgo e RONEK, Antônio."A Revolta" In O Cruzeiro, Rio de Janeiro, 9/7/1955

SILVA, Arlindo e DAMM, Flavio. "Borlengui - o carrasco peronista" In O Cruzeiro, Rio de Janeiro, 23/07/1955.

SILVA, Arlindo. "Eles voltarão" In O Cruzeiro, Rio de Janeiro, 6/8/1955.

SILVA, Arlindo e DAMM, Flavio."O comediante da Plaza de Mayo" In O Cruzeiro, Rio de Janeiro, 24/9/1955.

SILVA, Arlindo e DAMM, Flavio. "Por que caiu Perón" In O Cruzeiro, Rio de Janeiro, $1 / 10 / 1955$.

“Denúncia contra Jango”. Seção Política In O Cruzeiro, Rio de Janeiro, 1/10/1955.

LEMOS, Ubiratan. “Adeus, Perón, Bem-vindo, Lonardi” In O Cruzeiro, Rio de Janeiro, 8/10/1955, p. 4-11.

ANDRADE, Theóphilo de. "A queda de Perón" In O Cruzeiro, Rio de Janeiro, 8/10/1955, p. 89.

"Vitórias que poderão perturbar". Seção Política In O Cruzeiro, Rio de Janeiro, 8/10/1955, p. 84-85.

SILVA, Arlindo. "'O Cruzeiro" lutou contra o ditador Perón" In O Cruzeiro, Rio de Janeiro, 15/10/1955

NASSER, David. “Tango do Adeus” In O Cruzeiro, Rio de Janeiro, 15/10/1955, p. 12.

"Os índices favorecem Juscelino". Coluna Política In O Cruzeiro, Rio de Janeiro, $15 / 10 / 1955$

ATHAYDE, Austregésilo de. "Saudades do feitor" In: O Cruzeiro, Rio de Janeiro, 22/10/1955.

MARTINS, João. "Um ditador em férias" In: O Cruzeiro, Rio de Janeiro, 22/10/1955.

"O povo falou; os políticos interpretam". Coluna Política In: O Cruzeiro, Rio de Janeiro, 22/10/1955.

ATHAYDE, Austregésilo de. "A fábula do diabo" In O Cruzeiro, Rio de Janeiro, 29/10/1955. 
"A carta é falsa: consequências e novidades". Seção Política In O Cruzeiro, Rio de Janeiro, 29/10/1955.

WANDERLEY, Indalécio e RONEK, Antônio. "Amores e joias de Don Juan Perón" In O Cruzeiro, Rio de Janeiro, 29/10/1955.

QUEIROZ, Rachel de. "Perón” In O Cruzeiro, Rio de Janeiro, 29/10/1955.

RONEK, Antonio. "O tesouro que Perón esqueceu" In O Cruzeiro, Rio de Janeiro, $5 / 11 / 1955$.

PEARSON, Drew. "Um grupo de homens governa o país" In O Cruzeiro, Rio de Janeiro, 5/11/1955.

GASPAR, Carlos e RONEK, Carlos. "A volta de Tato" In O Cruzeiro, Rio de Janeiro, $12 / 11 / 1955$

ANDRADE, Theophilo de. "A Marcha da Revolução na Argentina" In O Cruzeiro, Rio de Janeiro, 19/11/1955.

GASPAR, Carlos e RONEK, Antônio. "Cinema argentino - passado, presente, futuro" In O Cruzeiro, Rio de Janeiro, 19/11/1955.

"O Cruzeiro triunfa na Argentina" In O Cruzeiro, Rio de Janeiro, 19/11/1955.

GASPAR, Carlos e RONEK, Antônio. "O portenho Walter Pinto" In O Cruzeiro, Rio de Janeiro, 26/11/1955.

LEMOS, Ubiratan e WANDERLEY, Indalécio. "Brandi” In O Cruzeiro, Rio de Janeiro, 10/12/1955.

"Parlamento". Seção Política. In O Cruzeiro, Rio de Janeiro, 10/12/1955, p. 119.

BARRETO, Luiz Carlos. "A realidade do futebol argentino" In O Cruzeiro, Rio de Janeiro, 17/12/1955, p. 50 a 50-G. 


\section{b) Posições dos jornais cariocas a respeito do peronismo de acordo com a diplomacia argentina (1954).}

A compilação a seguir foi feita a partir da nota secreta no. 888/1954 de 27 de julho de 1954, produzida pela embaixada argentina no Rio de Janeiro. As informações foram publicadas no livro de Hamilton Almeida. ${ }^{750}$

\section{LEGENDA DAS TABELAS:}

- T (Tiragem) : em mil das edições que circulavam de segunda a sexta-feira. No domingo, os jornais geralmente tinham tiragem maior.

- C (Circulação) - momento do dia em que o jornal circulava.

- M - Matutino.

- $\mathrm{V}$ - Vespertino.

\section{Jornais cariocas contrários ao peronismo}

\section{T C Posições políticas Posição a respeito da Argentina peronista}

\begin{tabular}{ccccc}
$\begin{array}{c}\text { Correio da } \\
\text { Manhã }\end{array}$ & 70 & - & $\begin{array}{c}\text { Anti-Vargas } \\
\text { Udenista } \\
\text { Pró-EUA }\end{array}$ & $\begin{array}{l}\text { "Contrário à República Argentina e ao seu } \\
\text { governo" }\end{array}$ \\
\hline O Jornal & 70 & $\mathrm{M}$ & $\begin{array}{c}\text { Anti-Vargas } \\
\text { "Entreguista" }\end{array}$ & "(...) inimigo de nosso país e governo". \\
\hline $\begin{array}{c}\text { Diário de } \\
\text { Notícias }\end{array}$ & 50 & $\mathrm{M}$ & $\begin{array}{c}\text { Anti-Vargas } \\
\text { Udenista }\end{array}$ & $\begin{array}{l}\text { "Não costuma atacar nosso governo, mas } \\
\text { reproduz extensamente notícias [das agências } \\
\text { internacionais] que aparecem nesse sentido". }\end{array}$ \\
\hline $\begin{array}{c}\text { Diário } \\
\text { Carioca }\end{array}$ & 40 & $\mathrm{M}$ & $\begin{array}{c}\text { Anti-Vargas } \\
\text { Udenista } \\
\text { Pró-EUA }\end{array}$ & $\begin{array}{l}\text { "Orientado por J.B. de Macedo Soares (...) ataca o } \\
\text { nosso país e o presidente general Perón em todas } \\
\text { as oportunidades". }\end{array}$ \\
\hline
\end{tabular}

${ }^{750}$ ALMEIDA, 2005, op. cit., p. 149-172. 


\begin{tabular}{|c|c|c|c|c|}
\hline O Globo & 110 & V & $\begin{array}{l}\text { Anti-Vargas } \\
\text { Não está ligado a } \\
\text { partidos } \\
\text { Pró-EUA }\end{array}$ & $\begin{array}{l}\text { "Esteve vinculado ao Itamaraty, por intermédio do } \\
\text { chanceler João Neves da Fontoura, que tinha } \\
\text { interesses e amizades no jornal, usando-o para } \\
\text { iniciar campanhas que lhe eram úteis em algum } \\
\text { sentido. Destacou-se então pelos ataques contra } \\
\text { a República Argentina e seu governo. Depois, } \\
\text { passou a atuar com maior ponderação e } \\
\text { equilíbrio, embora sempre como opositor" }\end{array}$ \\
\hline $\begin{array}{c}\text { Diário da } \\
\text { Noite }\end{array}$ & 80 & V & Não informado & $\begin{array}{l}\text { "Sensacionalista. (...) De forma constante, } \\
\text { desenvolve campanhas contra nosso país e } \\
\text { governo, baseado em calúnias, injúrias e } \\
\text { mentiras". }\end{array}$ \\
\hline $\begin{array}{l}\text { Tribuna da } \\
\text { Imprensa }\end{array}$ & 25 & V & $\begin{array}{l}\text { Anti-Vargas } \\
\text { Udenista } \\
\text { Pró-EUA }\end{array}$ & $\begin{array}{l}\text { "(...) aproveita qualquer oportunidade para fazer } \\
\text { virulentos ataques contra o país e o governo. } \\
\text { Recebe colaborações de exilados argentinos. } \\
\text { Costuma publicar calúnias, injúrias e mentiras } \\
\text { contra nossas autoridades públicas. O jornal está } \\
\text { a serviço das ambições políticas de seu diretor, } \\
\text { que deseja destacar-se mediante campanhas de } \\
\text { moralização do ambiente brasileiro e de ataque à } \\
\text { República Argentina" }\end{array}$ \\
\hline $\begin{array}{c}\text { Imprensa } \\
\text { Popular }\end{array}$ & - & - & $\begin{array}{l}\text { Comunista } \\
\text { Anti-Vargas } \\
\text { Anti-EUA }\end{array}$ & $\begin{array}{l}\text { "Com relação ao nosso país, são poucas as } \\
\text { publicações que realiza, mas critica o nosso } \\
\text { governo. Algumas vezes publica } \\
\text { correspondências do líder comunista argentino } \\
\text { Américo Ghioldi, que descreve com maldade a } \\
\text { situação interna em nosso país". }\end{array}$ \\
\hline $\begin{array}{c}\text { A Força da } \\
\text { Razão }\end{array}$ & - & - & $\begin{array}{l}\text { Anti-Vargas } \\
\text { Anticomunista } \\
\text { Pró-EUA }\end{array}$ & $\begin{array}{l}\text { "Em seus primeiros números publicou violentos } \\
\text { ataques contra o governo argentino. Nos números } \\
\text { seguintes, suavizou o tom, sem que exista um } \\
\text { motivo aparente para o fato". }\end{array}$ \\
\hline $\begin{array}{c}\text { Jornal do } \\
\text { Brasil }\end{array}$ & 45 & M & $\begin{array}{l}\text { Conservador } \\
\text { Não está ligado a } \\
\text { nenhum partido } \\
\text { Tendência católica }\end{array}$ & $\begin{array}{l}\text { "Em relação ao nosso país, ocasionalmente ataca } \\
\text { a orientação política do governo argentino, mas } \\
\text { sem chegar aos extremos alcançados pelo } \\
\text { Correio da Manhã e O Jornal". }\end{array}$ \\
\hline
\end{tabular}




\section{Jornais cariocas neutros em relação ao peronismo}

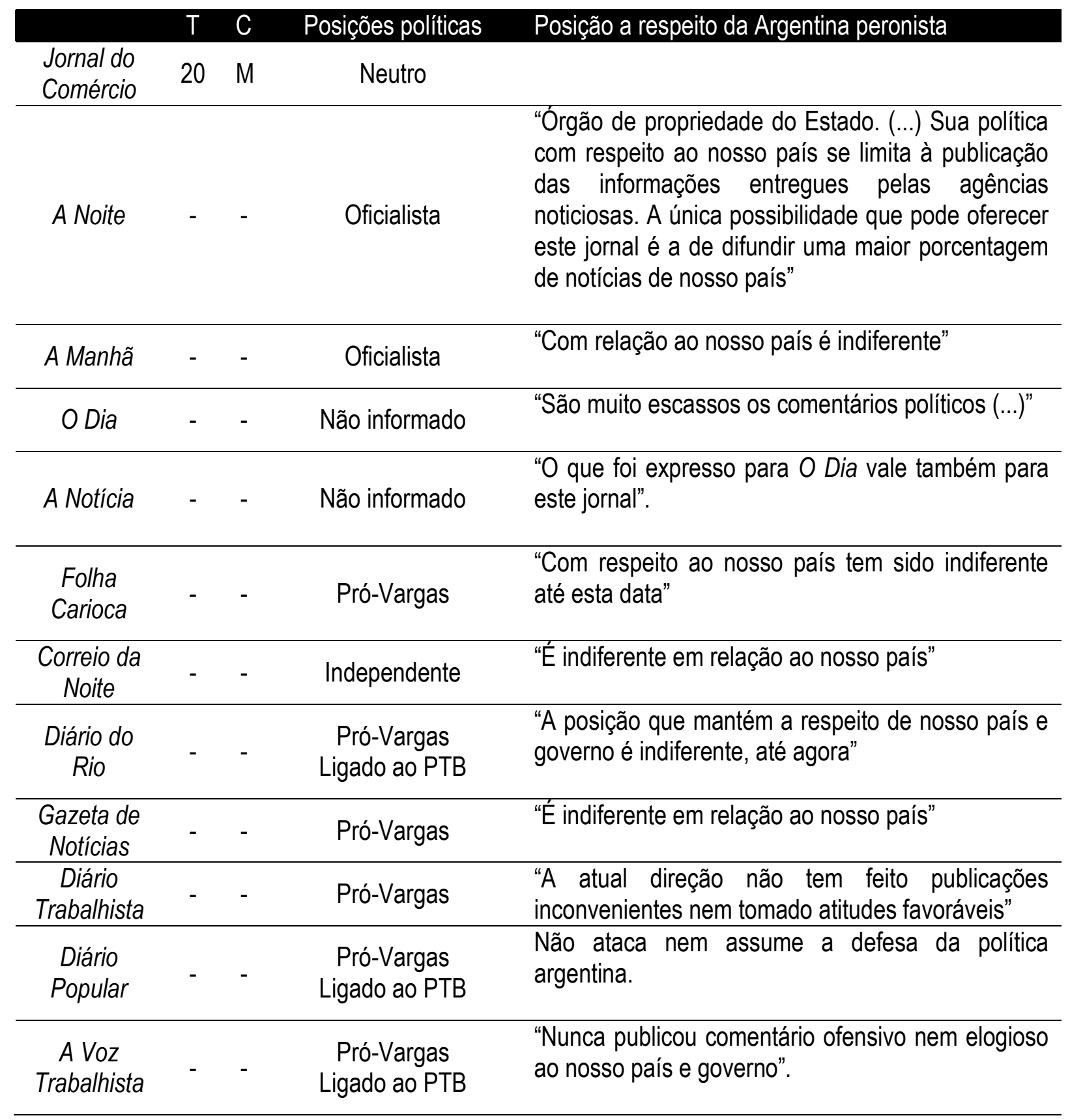




\section{Jornais cariocas a favor do peronismo.}

\begin{tabular}{|c|c|c|c|c|}
\hline O Mundo & $\begin{array}{c}\mathrm{T} \\
50\end{array}$ & $\begin{array}{l}\text { C } \\
?\end{array}$ & $\begin{array}{l}\text { Posições políticas } \\
\text { Anti-EUA }\end{array}$ & $\begin{array}{l}\text { Posição a respeito da Argentina peronista } \\
\text { "E defensor da República Argentina e de seu governo. } \\
\text { Suas edições têm certo caráter sensacionalista e } \\
\text { popular". }\end{array}$ \\
\hline última Hora & 90 & V & $\begin{array}{l}\text { Pró-Vargas } \\
\text { "Esquerdista e } \\
\text { popular" }\end{array}$ & $\begin{array}{l}\text { "Neste jornal colaboram diversos jornalistas argentinos. } \\
\text { Costuma defender a política do governo argentino." }\end{array}$ \\
\hline O Radical & & - & Pró-Vargas & $\begin{array}{l}\text { "Embora seu diretor manifeste em infinitas } \\
\text { oportunidades sua simpatia ao país e ao governo, raras } \\
\text { são as ocasiões em que O Radical assume uma posição } \\
\text { clara e definida em favor da Argentina. A sua ação se } \\
\text { limita a publicar algumas notícias da Agência Latina e a } \\
\text { copiar artigos publicados em jornais de nosso país, mas } \\
\text { sem se responsabilizar pelos conceitos emitidos". }\end{array}$ \\
\hline Vanguarda & - & - & $\begin{array}{l}\text { Ligado ao PTB } \\
\text { Anti-EUA }\end{array}$ & $\begin{array}{l}\text { "Suas publicações favoráveis ao nosso governo devem- } \\
\text { se sempre à influência do dr. Leopoldo P. da Silva" }\end{array}$ \\
\hline
\end{tabular}

